\title{
Breathing room: Restoring free rotation in a Schiff-base macrocycle through endoperoxide formation
}

\section{Mohammad T. Chaudhry, Seiya Ota, Francesco Lelj*, Mark J. MacLachlan*}

\begin{abstract}
a. Department of Chemistry, University of British Columbia, 2036 Main Mall, Vancouver, BC, Canada, V6T 1 Z1.

b. La.M.I. and LaSCAMM INSTM Sezione Basilicata, Dipartimento di Chimica, Universita` della Basilicata, via dell'Ateneo Lucano 10, 85100 Potenza, Italy

c. WPI Nano Life Science Institute, Kanazawa University, Kanazawa 920-1192, Japan.

d. Quantum Matter Institute, University of British Columbia, 2355 East Mall, Vancouver, BC, Canada, V6T $1 Z 4$.
\end{abstract}




\section{Table of Contents}

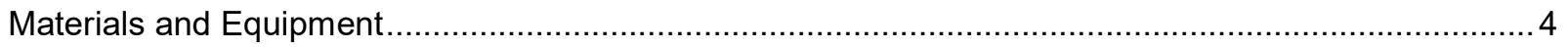

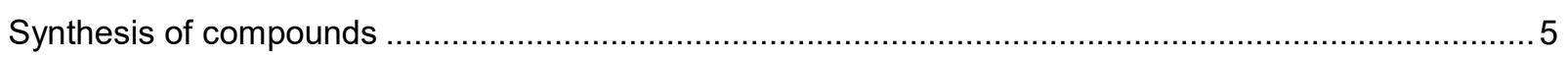

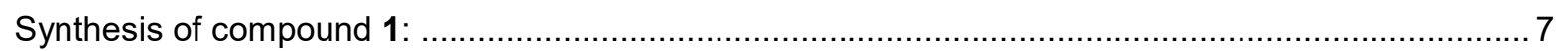

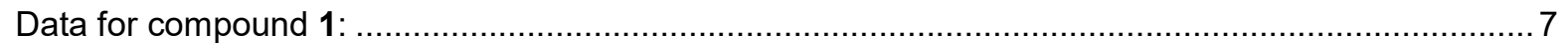

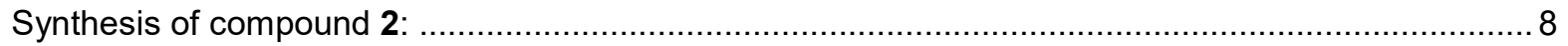

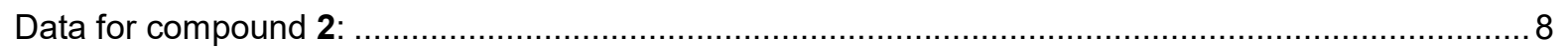

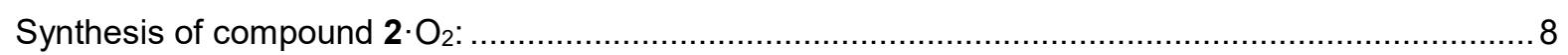

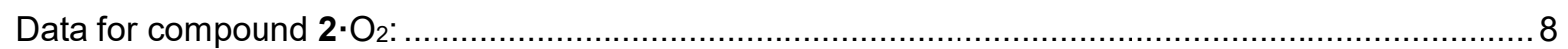

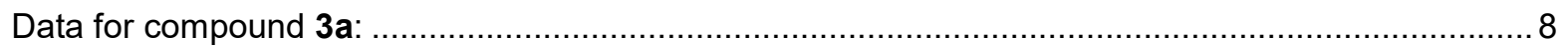

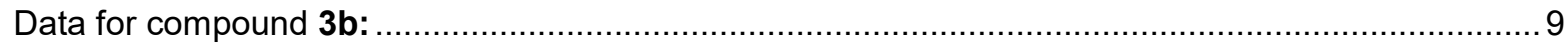

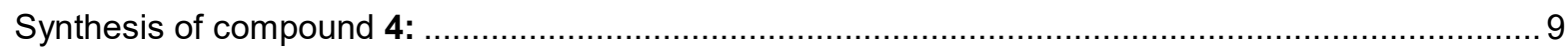

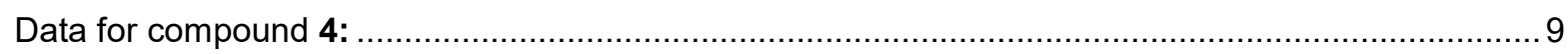

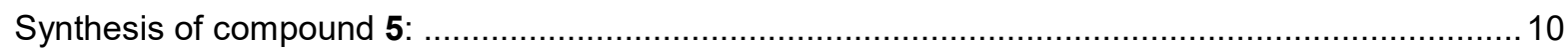

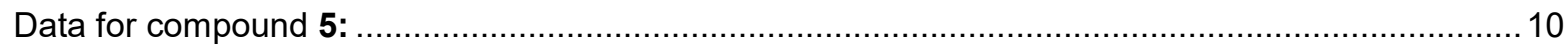

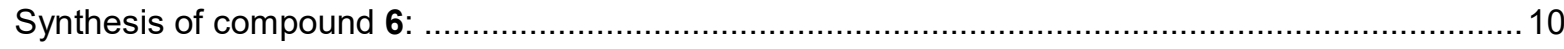

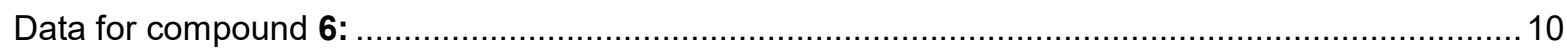

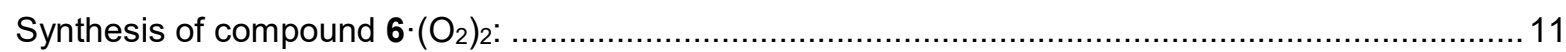

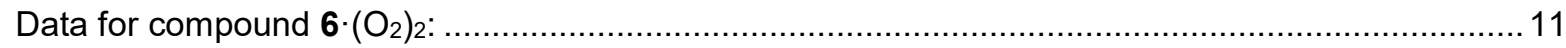

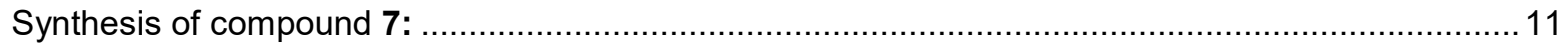

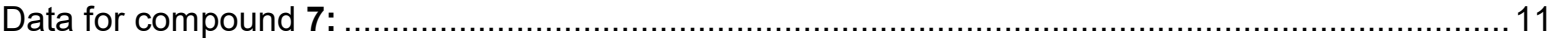

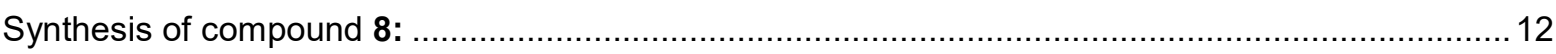

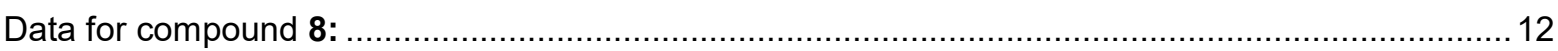

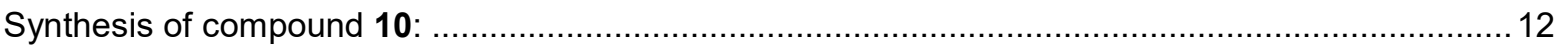

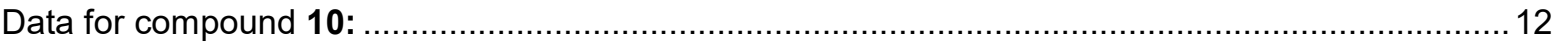

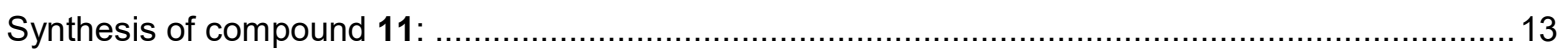

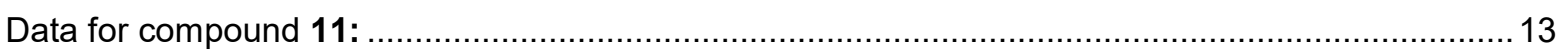

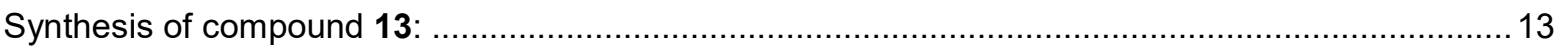

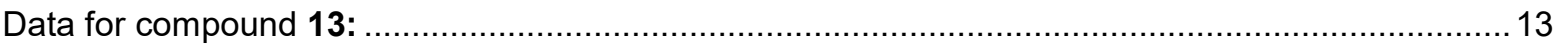

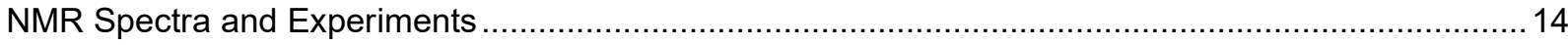

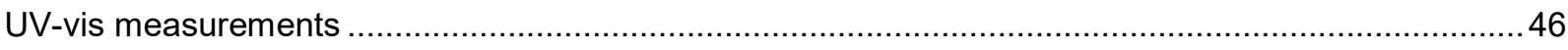

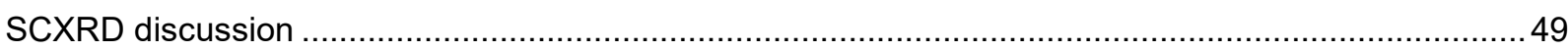

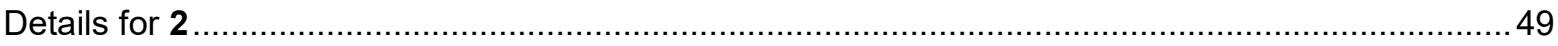

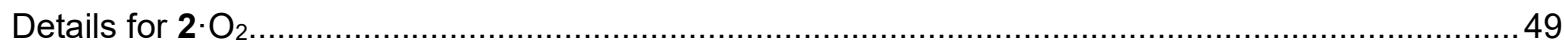

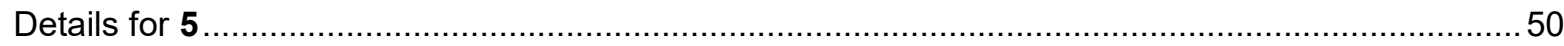

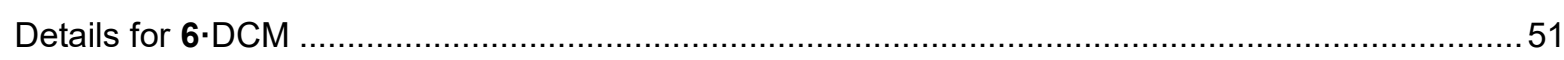

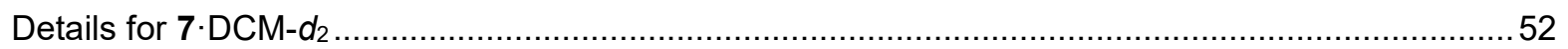




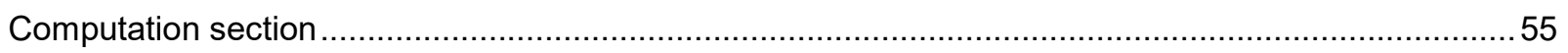

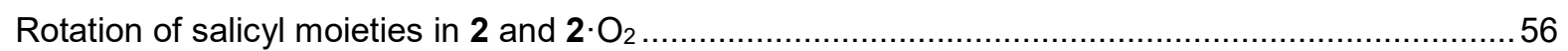

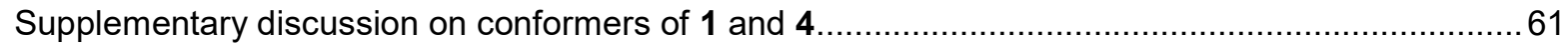

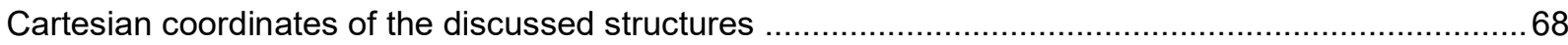

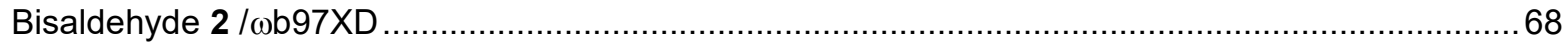

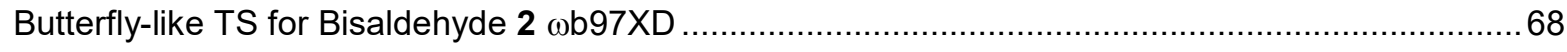

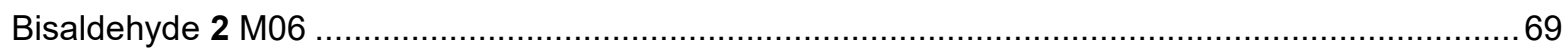

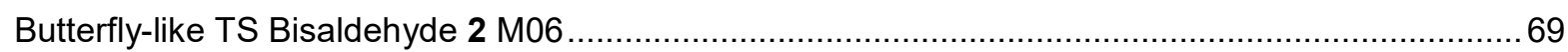

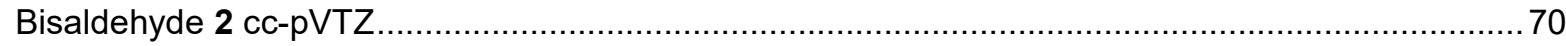

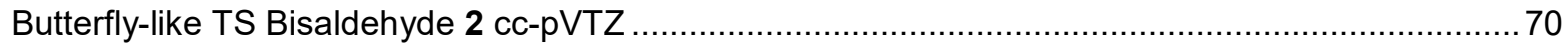

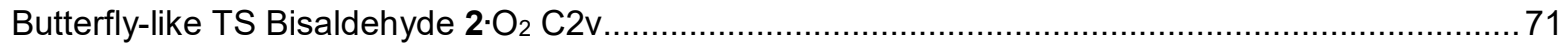

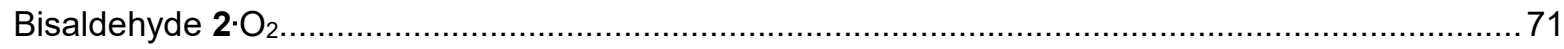

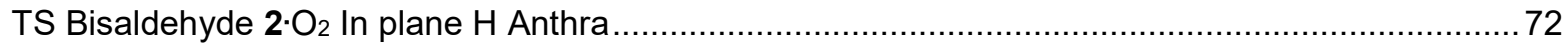

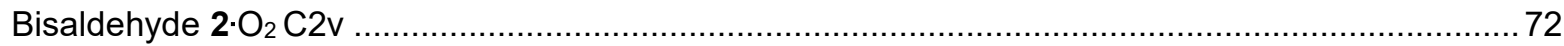

TS Bisaldehyde $2 \cdot \mathrm{O}_{2}$ Phenol in plane $\mathrm{H}$ Anthra PheOHCHO O2 bridge .......................................73

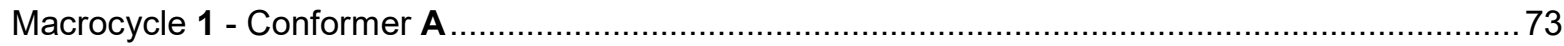

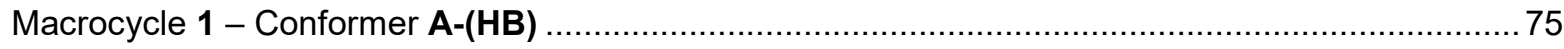

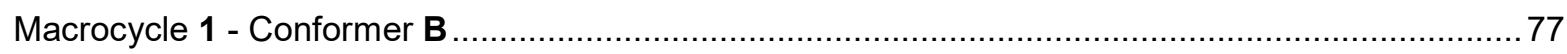

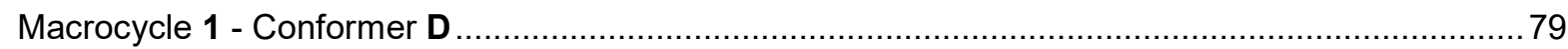

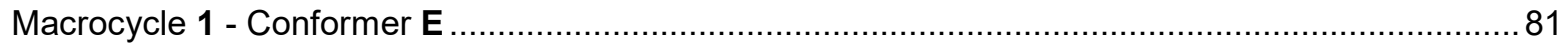

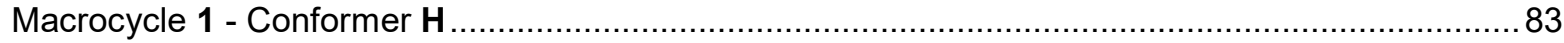

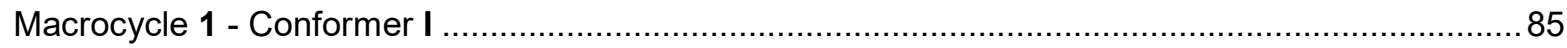

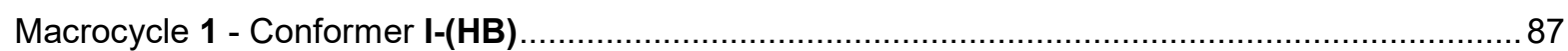

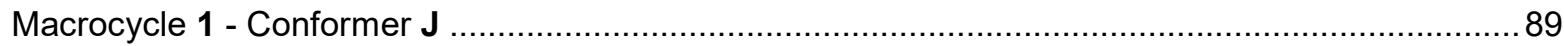

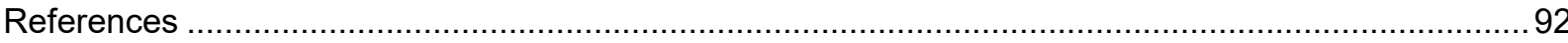




\section{Materials and Equipment}

All solvents and reagents were used as received, unless otherwise stated. All reactions were conducted under air unless stated otherwise. Dry tetrahydrofuran (THF) was obtained from an Inert PureSolv MD5 Solvent Purification System.

4,5-Diamino-1,2-bis(dodecyloxy)benzene $\quad(3 \mathbf{a}),{ }^{1} \quad$ 4,5-diamino-1,2-diethoxybenzene $\quad(3 \mathbf{b}){ }^{2} \quad 9,10$ anthracenediboronic acid bis(pinacol) ester (10), ${ }^{3}$ 4-iodo-2-hydroxybenzaldehyde (11), ${ }^{4}$ and 9 anthracenediboronic acid bis(pinacol) ester $(13)^{3}$ were prepared using modified versions of previously published methods.

Reagents were obtained from the following suppliers: 9,10-dibromoanthracene (9) (Alfa-Aesar), 9bromoanthracene (12) (TCI Chemicals), and 3-iodophenol (Sigma-Aldrich). Matrix compound trans-2-[3-(4tert-butylphenyl)-2-methyl-2-propenylidene]malononitrile (dctb) was purchased from Sigma-Aldrich. Dichloromethane- $d_{2}\left(\mathrm{DCM}-d_{2}\right)$, dimethylsulfoxide- $d_{6}$ (DMSO- $\left.d_{6}\right)$, tetrahydrofuran- $d_{8}\left(\right.$ THF- $\left.d_{8}\right)$, benzene- $d_{6}$ $\left(\mathrm{C}_{6} \mathrm{D}_{6}\right)$, and toluene- $d_{8}\left(\mathrm{PhMe}-d_{8}\right)$ were obtained from Sigma-Aldrich. Chloroform- $d_{1}\left(\mathrm{CDCl}_{3}\right)$ and 1,1,2,2tetrachloroethane- $d_{2} \quad\left(1,1,2,2-\mathrm{TCE}-d_{2}\right)$ were obtained from Cambridge Isotopes. Flash column chromatography was performed using SiliCycle (230-400 mesh) silica gel as the stationary phase. Photochemical reactions were conducted using a Westinghouse 100-Watt LED light bulb $(600 \mathrm{~nm})$ and a desktop lamp.

Nuclear magnetic resonance (NMR) spectra were recorded on a Bruker AV-400 or AV-600 MHz spectrometer and chemical shifts $(\delta)$ were referenced to residual proton signal of the employed deuterated solvent. Coupling constants $(J)$ are given in $\mathrm{Hz}$, and multiplicity is denoted by the following: singlet (s), doublet (d), doublet of doublets (dd), triplet (t), quartet (q), multiplet (m), broad signal (br). ${ }^{1} \mathrm{H}$ NMR spectra were generally assigned though 2D NMR experiments where applicable.

Mass spectra (MS) were obtained using electrospray ionization (ESI) on a Bruker Esquire-LC ion trap mass spectrometer equipped with an electrospray ion source or a matrix assisted laser desorption/ionization (MALDI) equipped with a Bruker Biflex IV time-of-flight (TOF) mass spectrometer. High-resolution mass spectra were obtained using an ESI-TOF Waters Micromass LCT spectrometer. Ultraviolet-visible (UV-vis) spectra were obtained on a Varian Cary 5000 UV-vis-near-IR spectrophotometer using a $1 \mathrm{~cm}$ pathlength quartz cuvette.

Single crystal X-ray diffraction (SCXRD) data were obtained using a Bruker APEX X8 or DUO instrument, equipped with a graphite monochromated Mo Ka radiation $(\lambda=0.71073 \AA)$ to a resolution of $0.83 \AA$ unless explicitly stated. Data were processed using Bruker APEX3, and an error model was completed using SAINT V8.38. ${ }^{5}$ Structure solutions were done using SHEL-XT with the intrinsic phasing method. ${ }^{6}$ Structure refinement was done using SHEL-XL using the least squares method. ${ }^{7}$ Both solution and refinement were done using the Olex2 interface. ${ }^{8}$ All non-hydrogen atoms were modelled anisotropically, with hydrogen atoms being modelled isotropically. Hydrogen atoms were also modelled with geometric constraints for bond lengths and angles. Graphical representation of CIF data was prepared using CrystalMaker ${ }^{9}{ }^{9} \mathrm{CIF}$ data are provided, along with detailed Reponses for $A$ and $B$ level alerts.

Detailed crystallographic discussion is given for each sample in the "SCXRD discussion" section. 


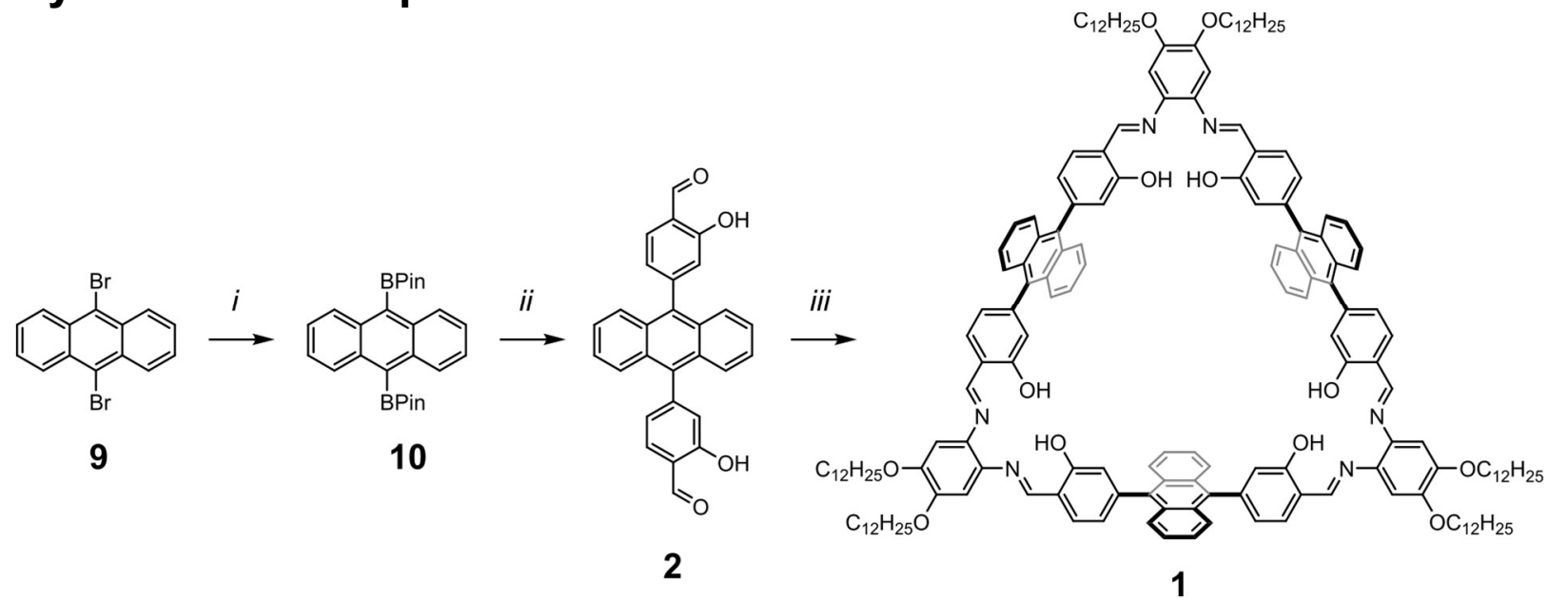

Scheme S1. Synthesis of 1 from 9. Reaction conditions: i) $\mathrm{B}_{2} \mathrm{Pin}_{2}, \mathrm{KOAc}, \mathrm{Pd}(\mathrm{OAc})_{2}$, dry DMF, dark, $80^{\circ} \mathrm{C}$, $\mathrm{N}_{2}, 48 \mathrm{~h}$. ii) 4-lodo-2-hydroxybenzaldehyde (11), $\mathrm{Pd}\left(\mathrm{PPh}_{3}\right)_{4}, \mathrm{~K}_{2} \mathrm{CO}_{3}, \mathrm{PhMe} / \mathrm{EtOH} / \mathrm{H}_{2} \mathrm{O}(4: 1: 1), 80^{\circ} \mathrm{C}, 48 \mathrm{~h}$. iii) 2, 3a, $\mathrm{CHCl}_{3} / \mathrm{MeCN}(2: 1)$, dark, reflux, $\mathrm{N}_{2}, 36 \mathrm{~h}$.

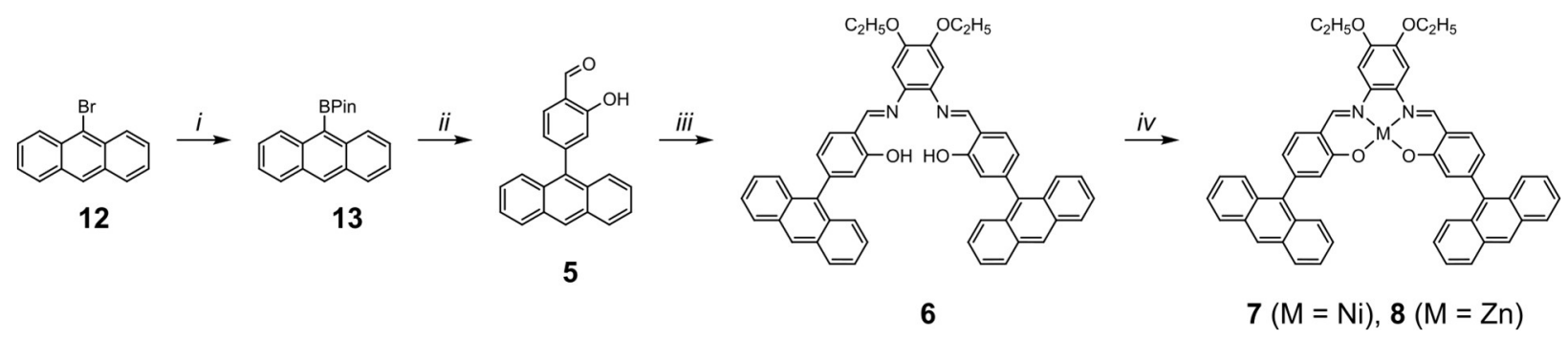

Scheme S2. Synthesis of complexes 7 and 8 from 12. Reaction conditions: i) $B_{2} P i n_{2}, K O A c, P d(O A c) 2$, dry DMF, dark, $100^{\circ} \mathrm{C}, \mathrm{N}_{2}, 48 \mathrm{~h}$. ii) 4-lodo-2-hydroxybenzaldehyde (11), $\mathrm{Pd}\left(\mathrm{PPh}_{3}\right)_{4}, \mathrm{~K}_{2} \mathrm{CO}_{3}$, $\mathrm{PhMe} / \mathrm{EtOH} / \mathrm{H}_{2} \mathrm{O}(4: 1: 1), 80{ }^{\circ} \mathrm{C}, 48 \mathrm{~h}$. iii) 3b, $\mathrm{CHCl}_{3} / \mathrm{MeOH}(1: 1)$, dark, reflux, $\mathrm{N}_{2}, 16 \mathrm{~h}$. iv) For 7 :

$\mathrm{Ni}(\mathrm{OAc})_{2} \cdot 4 \mathrm{H}_{2} \mathrm{O}, \mathrm{DCM} / \mathrm{MeOH}(6: 1), 35^{\circ} \mathrm{C}, \mathrm{N}_{2}, 16$ h. For 8: $\mathrm{Zn}\left(\mathrm{O}_{2} \mathrm{C}_{2} \mathrm{~F}_{3}\right)_{2} \cdot x \mathrm{H}_{2} \mathrm{O}, \mathrm{CHCl}_{3} / \mathrm{MeOH}$, dark, reflux, $\mathrm{N}_{2}, 18 \mathrm{~h}$.

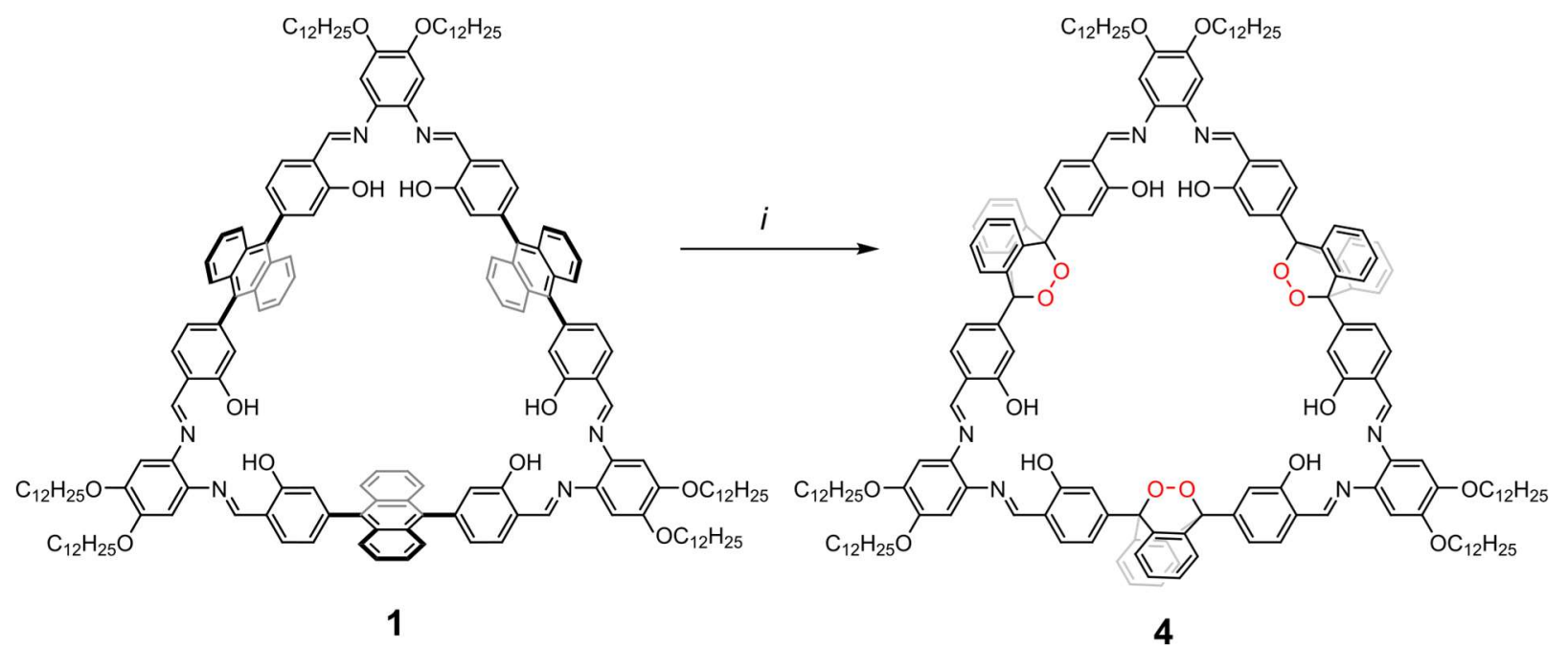

Scheme S3. Synthesis of 4 from 1. Reaction conditions: i) Methylene blue chloride (MB-Cl), $\mathrm{CHCl}_{3}, 600$ $\mathrm{nm} h v$ (100 Watt), $4 \mathrm{~h}$. 


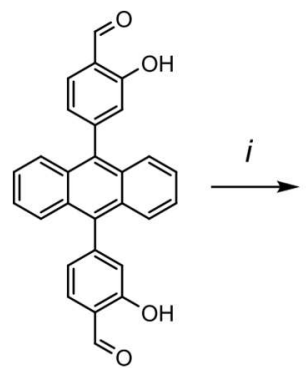

2

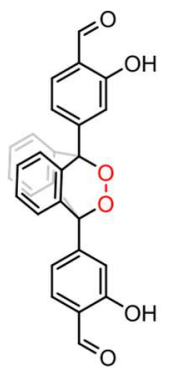

$2 \cdot\left(\mathrm{O}_{2}\right)$

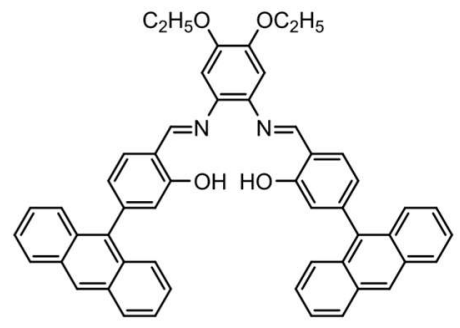

6

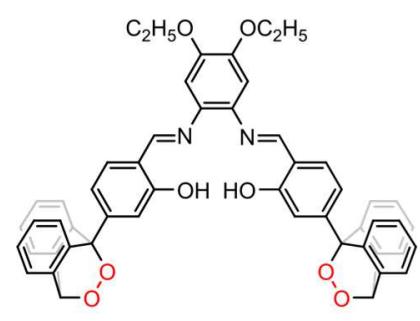

6. $\left(\mathrm{O}_{2}\right)_{2}$

Scheme S4. Synthesis of endoperoxide compounds from 2 and $\mathbf{6}$, respectively. Reaction conditions: i) Methylene blue chloride (MB-Cl), $\mathrm{CHCl}_{3}, 600 \mathrm{~nm} \mathrm{hv}$ (100 Watt), 0.5-2 h. 


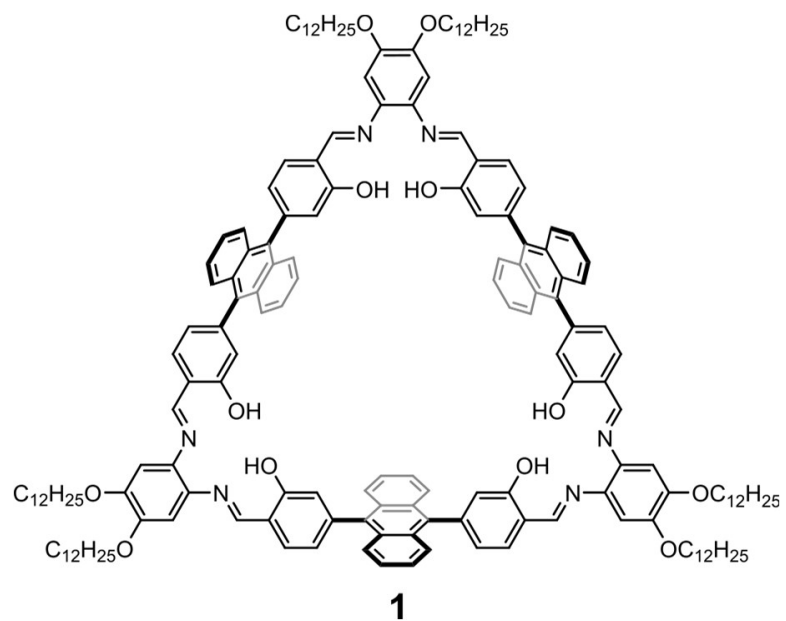

Synthesis of compound 1:

Compound 1 has been prepared using several methods (e.g., glovebox, rigorous degassing of solvent with freeze-pump-thaw, using a Schlenk line in the dark). Thus, we report the simplest synthesis. Early on, we attempted the macrocyclization reaction using toluene and no macrocycle was detected. We also tried using just $\mathrm{CHCl}_{3}$, but oligomeric byproducts were obtained.

Compound 2 (15.0 mg, $35 \mu \mathrm{mol}$ ) and $3 \mathrm{a}$ ( $17.4 \mathrm{mg}, 36 \mu \mathrm{mol})$ were combined in a 2 neck-round bottom-flask equipped with a reflux condenser. The solids were backfilled with $\mathrm{N}_{2}(\times 3)$, followed by addition of previously degassed $\mathrm{CHCl}_{3} / \mathrm{MeCN}(2: 1,5 \mathrm{~mL})$. The yellow suspension was heated at $80^{\circ} \mathrm{C}$ in an oil bath for $36 \mathrm{~h}$ in the dark. The mixture was then cooled to $-10^{\circ} \mathrm{C}$, filtered, then washed with cold $\mathrm{CHCl}_{3}(2 \mathrm{~mL})$, and $\mathrm{MeCN}$ $(5 \mathrm{~mL})$, yielding macrocycle 1 as an orange solid $(23.5 \mathrm{mg}, 9.1 \mu \mathrm{mol}, 76 \%)$.

\section{Data for compound 1:}

${ }^{1} \mathrm{H}$ NMR (400 MHz, DCM- $d_{2}$ ): $\delta 13.70(\mathrm{~s}, 6 \mathrm{H}), 8.89(\mathrm{~s}, 6 \mathrm{H}), 7.74(\mathrm{dd}, J=6.9,3.2 \mathrm{~Hz}, 12 \mathrm{H}), 7.71$ (d, $J=10.3$ $\mathrm{Hz}, 6 \mathrm{H}), 7.34(\mathrm{dd}, J=6.9,3.3 \mathrm{~Hz}, 12 \mathrm{H}), 7.12(\mathrm{~s}, 12 \mathrm{H}), 7.02(\mathrm{~s}, 6 \mathrm{H}), 4.17(\mathrm{~s}, 12 \mathrm{H}), 1.90(\mathrm{q}, J=7.0 \mathrm{~Hz}, 24 \mathrm{H})$, $1.48-1.20(\mathrm{~m}, 96 \mathrm{H}), 1.01-0.84(\mathrm{~m}, 18 \mathrm{H}) .{ }^{13} \mathbf{C}\left\{{ }^{1} \mathrm{H}\right\}$ NMR $\left(101 \mathrm{MHz}, \mathrm{DCM}-\mathrm{d}_{2}\right): \delta$ 161.6, 161.4, 150.0, 144.9, 136.8, 136.3, 132.5, 129.7, 127.1, 125.7, 122.5, 120.7, 119.4, 104.5, 70.2, 32.4, 30.2, 30.1, 29.89, 29.81, 26.5, 23.1, 14.3 (some alkyl peaks missing/overlapping). LRMS (MALDI-TOF, dctb) $\mathbf{m} / \mathbf{z}:[\mathbf{1}+\mathrm{H}]^{+}$calcd for ${ }^{13} \mathrm{C}_{1}{ }^{12} \mathrm{C}_{173} \mathrm{H}_{210} \mathrm{~N}_{6} \mathrm{O}_{12} 2577.6$; Found 2577.1. UV-vis $\left(\boldsymbol{\varepsilon} / \mathbf{M}^{-1} \mathbf{c m}^{-1}\right)$ in DCM: $7.25 \times 10^{4}(398 \mathrm{~nm}), 6.44 \times 10^{4}$ (383 nm), $4.95 \times 10^{4}(360 \mathrm{~nm}), 4.45 \times 10^{4}(344 \mathrm{~nm})$.<smiles>O=Cc1ccc(-c2ccccc2-c2ccccc2-c2cccc(O)c2)c(O)c1</smiles> 
Synthesis of compound 2:

Compounds 10 (750 mg, $3.02 \mathrm{mmol}$ ), 11 (368 mg, $0.86 \mathrm{mmol}$ ), $\mathrm{Pd}\left(\mathrm{PPh}_{3}\right)_{4}\left(120 \mathrm{mg}, 0.10 \mathrm{mmol}\right.$ ), and $\mathrm{K}_{2} \mathrm{CO}_{3}$ (750 mg, $5.43 \mathrm{mmol}$ ) were combined in a Schlenk flask and backfilled with $\mathrm{N}_{2}(\times 3)$. PhMe (56 mL), EtOH $(10 \mathrm{~mL})$, and $\mathrm{H}_{2} \mathrm{O}(18 \mathrm{~mL})$ were added via syringe. The mixture was heated at $80{ }^{\circ} \mathrm{C}$ in an oil bath for $48 \mathrm{~h}$ in the dark. The solution was partitioned with $\mathrm{H}_{2} \mathrm{O}(100 \mathrm{~mL})$, and the organic layer $(\mathrm{PhMe})$ was separated, and the aqueous layer was extracted with DCM $(3 \times 50 \mathrm{~mL})$. After drying the combined organic layers with $\mathrm{MgSO}_{4}$, filtered, the solvent was removed in vacuo. The oily brown crude was purified further through silica column chromatograph ( $\mathrm{CHCl}_{3} /$ hexanes, $\left.1: 1, \mathrm{R}_{\mathrm{f}}=0.30\right)$ to yield compound $2(232 \mathrm{mg}, 0.56 \mathrm{mmol}, 65 \%)$ as a dull yellow solid.

Data for compound 2:

${ }^{1} \mathrm{H}$ NMR $\left(400 \mathrm{MHz}, \mathrm{CDCl}_{3}\right)$ : $\delta 11.27$ (s, 1H, syn), 11.26 (s, 1H, anti), 10.09 (s, 2H), 7.81 (dd, $J=7.9,2.5$ $\mathrm{Hz}, 2 \mathrm{H}), 7.68$ (dd, $J=6.8,3.3 \mathrm{~Hz}, 4 \mathrm{H}), 7.39(\mathrm{dd}, J=6.9,3.2 \mathrm{~Hz}, 4 \mathrm{H}), 7.22-7.09(\mathrm{~m}, 4 \mathrm{H}) .{ }^{1}{ }^{3} \mathrm{C}\left\{{ }^{1} \mathrm{H}\right\} \mathrm{NMR}$ (101 MHz, $\mathrm{CDCl}_{3}$ ): $\delta$ 196.6, 161.9, 148.9, 136.0, 133.9, 128.7, 126.7, 126.0, 123.5, 120.8, 120.3. HRMS (ESI, MeOH/DCM) $\mathbf{m} / \mathbf{z}$ : [2]- Calcd for $\mathrm{C}_{28} \mathrm{H}_{17} \mathrm{O}_{4}$ 417.1132; Found 417.1135. UV-vis $\left(\varepsilon / \mathbf{~ M}^{-1} \mathbf{c m}^{-1}\right)$ in DCM: $1.30 \times 10^{4}(396 \mathrm{~nm}), 1.28 \times 10^{4}(377 \mathrm{~nm}), 9.81 \times 10^{3}(356 \mathrm{~nm}), 9.47 \times 10^{3}(341 \mathrm{~nm})$.

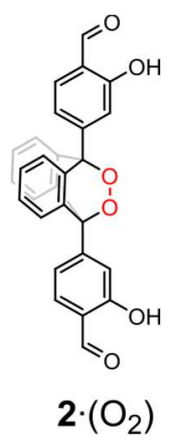

Synthesis of compound $2 \cdot \mathrm{O}_{2}$ :

Compound $2(25 \mathrm{mg}, 60 \mu \mathrm{mol})$ and $\mathrm{MB}-\mathrm{Cl}(0.2 \mathrm{mg}, 1.5 \mu \mathrm{mol})$ were added to a scintillation vial and dissolved in DCM $(6 \mathrm{~mL})$. The mixture was capped and irradiated $(600 \mathrm{~nm}, 100 \mathrm{~W})$ for $c a .8 \mathrm{~h}$, then the solvent was removed in vacuo, yielding a dark brown solid. The crude product was purified by silica column chromatography (DCM, $R_{f}=0.15$ ) to yield $\mathbf{2} \cdot \mathrm{O}_{2}$ as a brown solid ( $18 \mathrm{mg}, 39 \mu \mathrm{mol}, 67 \%$ ).

Data for compound $2 \cdot \mathrm{O}_{2}$ :

${ }^{1} \mathrm{H}$ NMR $\left(400 \mathrm{MHz}, \mathrm{CDCl}_{3}\right): \delta 11.21$ (s, 2H), $10.06(\mathrm{~s}, 2 \mathrm{H}), 7.85(\mathrm{~d}, J=7.9 \mathrm{~Hz}, 2 \mathrm{H}), 7.45-7.34(\mathrm{~m}, 4 \mathrm{H})$, $7.32-7.24(\mathrm{~m}, 4 \mathrm{H}), 7.24-7.13(\mathrm{~m}, 4 \mathrm{H}) .{ }^{13} \mathrm{C}\left\{{ }^{1} \mathrm{H}\right\}$ NMR $\left(101 \mathrm{MHz}, \mathrm{CDCl}_{3}\right): \delta$ 196.4, 161.6, 142.3, 139.1, 133.8, 128.3, 123.6, 120.6, 119.2, 117.4, 84.2. HRMS (ESI, MeOH/DCM) m/z: [2. $\left.\mathrm{O}_{2}\right]^{-}$Calcd for $\mathrm{C}_{28} \mathrm{H}_{17} \mathrm{O}_{6}$ 449.1031; Found 449.1038. UV-vis $\left(\varepsilon / \mathbf{M}^{-1} \mathbf{c m}^{-1}\right)$ in DCM: $2.13 \times 10^{4}(329 \mathrm{~nm})$.

Data for compound 3a:<smiles>CCCCCOc1cc(N)c(N)cc1OCCCC</smiles>

$3 a$ 
${ }^{1} \mathrm{H}$ NMR (400 MHz, DCM- $\left.d_{2}\right): \delta 6.34(\mathrm{~s}, 2 \mathrm{H}), 3.84(\mathrm{t}, \mathrm{J}=6.7 \mathrm{~Hz}, 4 \mathrm{H}), 1.77-1.65(\mathrm{~m}, 4 \mathrm{H}), 1.61(\mathrm{~s}(\mathrm{br}), 4 \mathrm{H})$, $1.48-1.38(\mathrm{~m}, 4 \mathrm{H}), 1.38-1.22(\mathrm{~m}, 32 \mathrm{H}), 0.92-0.84(\mathrm{~m}, 6 \mathrm{H})$. Spectral data matched previous reports. ${ }^{1}$

Data for compound 3b:<smiles>CCOc1cc(N)c(OCC)cc1N</smiles>

\section{$3 b$}

${ }^{1} \mathrm{H}$ NMR (400 MHz, $\left.\mathrm{CDCl}_{3}\right): \delta 6.38(\mathrm{~s}, 1 \mathrm{H}), 3.98(\mathrm{q}, J=7.0 \mathrm{~Hz}, 2 \mathrm{H}), 3.17(\mathrm{~s}, 3 \mathrm{H}), 1.38$ (t, $\left.J=7.0 \mathrm{~Hz}, 3 \mathrm{H}\right)$. ${ }^{13} \mathrm{C}\left\{{ }^{1} \mathrm{H}\right\}$ NMR $\left(101 \mathrm{MHz}, \mathrm{CDCl}_{3}\right): \delta 143.18,128.51,106.74,66.04,15.33$. Spectral data matched previous reports. ${ }^{2}$

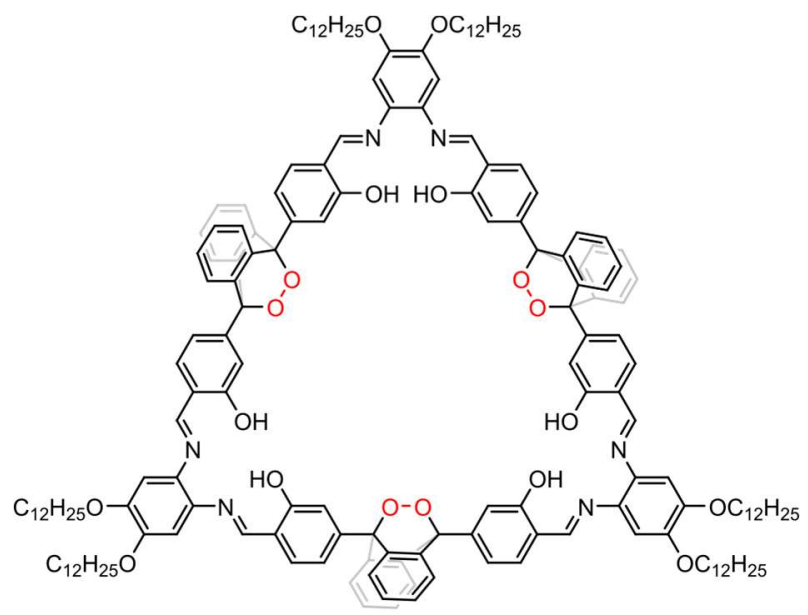

4

Synthesis of compound 4:

Compound $1(2.5 \mathrm{mg}, 9.7 \mu \mathrm{mol})$ and $\mathrm{MB}-\mathrm{Cl}(7 \mu \mathrm{g}, 0.2 \mu \mathrm{mol})$ were dissolved in $\mathrm{CDCl}_{3}(0.60 \mathrm{~mL})$ in an NMR tube. The mixture was irradiated with $h v(600 \mathrm{~nm}, 100 \mathrm{~W})$ for $4 \mathrm{~h}$ at room temperature. This compound was not isolated and instead studied in situ. From integration of the ${ }^{1} \mathrm{H}$ NMR signals, conversion from 1 to 4 $\left(\mathbf{1} \cdot\left(\mathrm{O}_{2}\right)_{3}\right)$ was quantitative.

\section{Data for compound 4:}

${ }^{1} \mathrm{H}$ NMR (400 MHz, $\left.\mathrm{CDCl}_{3}\right)$ : $\delta 13.56(\mathrm{~s}, 6 \mathrm{H}), 8.78(\mathrm{~s}, 6 \mathrm{H}), 7.65(\mathrm{~d}, J=8.1 \mathrm{~Hz}, 6 \mathrm{H}), 7.42(\mathrm{~d}, J=1.6 \mathrm{~Hz}, 6 \mathrm{H})$, $7.30-7.27(\mathrm{~m}, 6 \mathrm{H}), 7.25-7.17(\mathrm{~m}, 18 \mathrm{H}), 6.93(\mathrm{~s}, 6 \mathrm{H}), 4.14(\mathrm{t}, J=6.5 \mathrm{~Hz}, 12 \mathrm{H}), 2.10-1.82(\mathrm{~m}, 12 \mathrm{H}), 1.72$ $-1.48(\mathrm{~m}, 24 \mathrm{H}), 1.48-1.11(\mathrm{~m}, 114 \mathrm{H}), 0.89(\mathrm{t}, \mathrm{J}=6.6 \mathrm{~Hz}, 18 \mathrm{H}) \cdot{ }^{13} \mathrm{C}\left\{{ }^{1} \mathrm{H}\right\}$ NMR $\left(101 \mathrm{MHz}, \mathrm{CDCl}_{3}\right): \delta 161.2$, 149.7, 139.8, 138.4, 135.7, 132.6, 128.1, 123.1, 120.6, 118.0, 116.9, 105.4, 84.5, 70.2, 32.3, 30.05, 29.99, 29.8, 29.7, 29.6, 26.4, 23.0, 14.4. (some alkyl peaks missing/overlapping). LRMS (MALDI-TOF, dctb) $\mathbf{m} / \mathbf{z}$ : $[4+\mathrm{H}]^{+}$Calcd for ${ }^{13} \mathrm{C}_{1}{ }^{12} \mathrm{C}_{173} \mathrm{H}_{210} \mathrm{~N}_{6} \mathrm{O}_{18} 2672.6$; Found 2672.9. UV-vis $\left(\varepsilon / \mathbf{M}^{-1} \mathbf{c m}^{-1}\right)$ in DCM: $4.13 \times 10^{4}(347$ $\mathrm{nm}), 3.74 \times 10^{4}(380 \mathrm{~nm})$. 


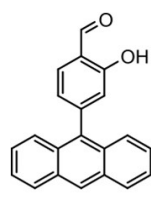

5

Synthesis of compound $\mathbf{5}$ :

Compounds 11 (279 mg, $0.92 \mathrm{mmol}), 12$ (300 mg, $1.69 \mathrm{mmol}), \mathrm{Pd}\left(\mathrm{PPh}_{3}\right)_{4}(130 \mathrm{mg}, 0.11 \mathrm{mmol})$, and $\mathrm{K}_{2} \mathrm{CO}_{3}$ (780 mg, $5.64 \mathrm{mmol}$ ) were combined in a Schlenk flask and backfilled with $\mathrm{N}_{2}(\mathrm{x} 3)$. PhMe $(30 \mathrm{~mL})$, EtOH $(10 \mathrm{~mL})$, and $\mathrm{H}_{2} \mathrm{O}(10 \mathrm{~mL})$ were added, and the mixture was heated at $80^{\circ} \mathrm{C}$ in an oil bath for $48 \mathrm{~h}$ in the dark. The solution was partitioned with brine $(100 \mathrm{~mL})$, the organic layer $(\mathrm{PhMe})$ was separated, and the aqueous layer was extracted with PhMe $(2 \times 100 \mathrm{~mL})$. After the combined organic layers were dried with $\mathrm{MgSO}_{4}$, the solution was filtered, and the solvent was removed in vacuo. The oily brown crude product was purified further through silica column chromatograph (DCM/hexanes, $\left.1: 1, R_{f}=0.40\right)$ to yield compound 5 (162 $\mathrm{mg}, 0.54 \mathrm{mmol}, 58 \%$ ) as yellow bright solid.

\section{Data for compound 5:}

${ }^{1} \mathrm{H}$ NMR (400 MHz, DCM-d ) $^{\circ} \delta 11.23$ (s, 1H), 10.07 (s, 1H), $8.56(\mathrm{~s}, 1 \mathrm{H}), 8.08$ (d, J = 8.5 Hz, 2H), 7.81 (d, $J=7.8 \mathrm{~Hz}, 2 \mathrm{H}$ ), 7.64 (d, $J=8.9,2 \mathrm{H}$ ), 7.49 (ddd, $J=8.3,6.6,1.2 \mathrm{~Hz}, 2 \mathrm{H}$ ), 7.40 (ddd, $J=8.8,6.5,1.3 \mathrm{~Hz}$, 2H), 7.11 (dd, $J=7.8,1.5 \mathrm{~Hz}, 1 \mathrm{H}), 7.08(\mathrm{~s}, 1 \mathrm{H}) .{ }^{13} \mathrm{C}\left\{{ }^{1} \mathrm{H}\right\}$ NMR (101 MHz, DCM-d $): \delta$ 197.2, 162.1, 149.1, 134.3, 131.8, 123.0, 129.0, 128.0, 126.6, 126.4, 125.8, 123.9, 120.9, 120.6 (1 peaks missing). HRMS (ESI, MeOH/DCM) $\mathbf{m} / \mathbf{z}$ : [5] - Calcd for $\mathrm{C}_{21} \mathrm{H}_{13} \mathrm{O}_{2}$ 297.0921; Found 297.0923. UV-vis ( $\left(\boldsymbol{\varepsilon} / \mathbf{~ M}^{-1} \mathbf{c m}^{-1}\right)$ in DCM: $9.26 \mathrm{x}$ $10^{3}(388 \mathrm{~nm}), 9.69 \times 10^{3}(366 \mathrm{~nm}), 7.60 \times 10^{3}(348 \mathrm{~nm}), 5.98 \times 10^{3}(332 \mathrm{~nm})$.

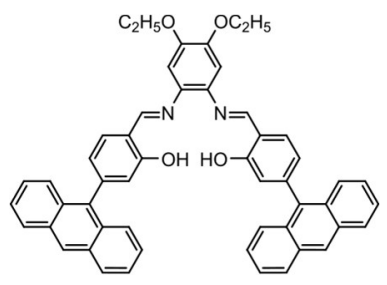

6

Synthesis of compound $\mathbf{6}$ :

Compound $5(25 \mathrm{mg}, 84 \mu \mathrm{mol})$ and $\mathbf{3 b}(8.1 \mathrm{mg}, 42 \mu \mathrm{mol})$ were combined in a 2 neck-round bottom-flask equipped with a reflux condenser. The solids were backfilled with $\mathrm{N}_{2}(\mathrm{x} 3)$, previously degassed $\mathrm{CHCl}_{3} / \mathrm{MeCN}(2: 1,5 \mathrm{~mL})$ was added, and the yellow suspension was heated at $80^{\circ} \mathrm{C}$ in an oil bath in the dark. After $36 \mathrm{~h}$, the mixture was cooled to $-10^{\circ} \mathrm{C}$, filtered, then washed with cold $\mathrm{CHCl}_{3}(2 \mathrm{~mL})$, and $\mathrm{MeCN}$ $(5 \mathrm{~mL})$, yielding compound 6 as a yellow solid $(16 \mathrm{mg})$. A second crop of crystals of 6 were obtained by cooling the filtrate at $-10^{\circ} \mathrm{C}(9 \mathrm{mg})$. Total yield $(25 \mathrm{mg}, 33 \mu \mathrm{mol}, 78 \%)$.

\section{Data for compound 6:}

${ }^{1} \mathrm{H}$ NMR (400 MHz, DCM- $d_{2}$ ): $\delta 13.50(\mathrm{~s}, 2 \mathrm{H}), 8.87(\mathrm{~s}, 2 \mathrm{H}), 8.52(\mathrm{~s}, 2 \mathrm{H}), 8.05$ (d, J = 8.5 Hz, 4H), 7.74 (s, $4 \mathrm{H}), 7.68(\mathrm{~d}, J=7.8 \mathrm{~Hz}, 2 \mathrm{H}), 7.51-7.43(\mathrm{~m}, 4 \mathrm{H}), 7.41-7.32(\mathrm{~m}, 4 \mathrm{H}), 7.12(\mathrm{~s}, 2 \mathrm{H}), 7.03(\mathrm{dd}, J=7.8,1.6$ $\mathrm{Hz}, 2 \mathrm{H}), 6.98(\mathrm{~s}, 2 \mathrm{H}), 4.23(\mathrm{q}, J=7.0 \mathrm{~Hz}, 4 \mathrm{H}), 1.53(\mathrm{t}, J=6.6 \mathrm{~Hz}, 6 \mathrm{H}) .{ }^{13} \mathrm{C}\left\{{ }^{1} \mathrm{H}\right\}$ NMR (101 MHz, DCM- $\left.\mathbf{d}_{2}\right):$ $\delta 162.4,161.6,149.5,144.8,136.5,136.2,132.7,131.9,130.3,128.8,127.4,127.1,126.1,125.8,123.0$, 120.6, 119.4, 105.1, 65.7, 15.3. HRMS (ESI, MeOH/DCM) m/z: [6+H] ${ }^{+}$Calcd for $\mathrm{C}_{52} \mathrm{H}_{41} \mathrm{~N}_{2} \mathrm{O}_{4} 757.3061$; Found 757.3059. UV-vis $\left(\boldsymbol{\varepsilon} / \mathbf{M}^{-1} \mathbf{c m}^{-1}\right)$ in DCM: $3.67 \times 10^{4}(388 \mathrm{~nm}), 3.41 \times 10^{4}(369 \mathrm{~nm}), 2.67 \times 10^{4}(354$ $\mathrm{nm}), 2.04 \times 10^{4}(340 \mathrm{~nm})$. 


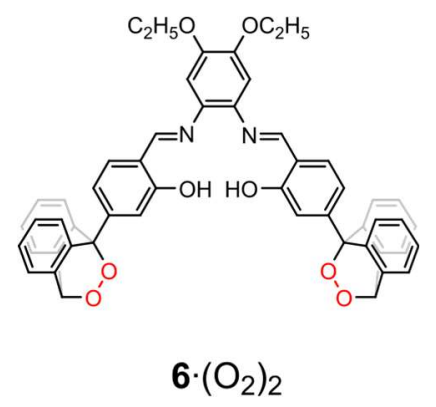

Synthesis of compound $\mathbf{6} \cdot\left(\mathrm{O}_{2}\right)_{2}$ :

Compound $6(3.3 \mathrm{mg}, 4.3 \mu \mathrm{mol})$ and $\mathrm{MB}-\mathrm{Cl}(10 \mu \mathrm{g}, 0.3 \mu \mathrm{mol})$ were dissolved in DCM- $d_{2}(0.60 \mathrm{~mL})$ in an NMR tube. The mixture was irradiated $(600 \mathrm{~nm}, 100 \mathrm{~W})$ for 60 mins at room temperature. This compound was not isolated and instead studied in situ. From integration of the ${ }^{1} \mathrm{H}$ NMR signals, conversion from 6 to 6. $\left(\mathrm{O}_{2}\right)_{2}$ was quantitative.

Data for compound $\mathbf{6} \cdot\left(\mathrm{O}_{2}\right)$ :

${ }^{1} \mathrm{H}$ NMR (400 MHz, DCM-d $)$ : $\delta 13.45(\mathrm{~s}, 2 \mathrm{H}), 8.82(\mathrm{~s}, 2 \mathrm{H}), 7.69(\mathrm{~d}, J=8.0 \mathrm{~Hz}, 2 \mathrm{H}), 7.51(\mathrm{~d}, J=8.1 \mathrm{~Hz}$, $2 \mathrm{H}), 7.38-7.29(\mathrm{~m}, 6 \mathrm{H}), 7.28-7.17(\mathrm{~m}, 12 \mathrm{H}), 6.95(\mathrm{~s}, 2 \mathrm{H}), 6.12(\mathrm{~s}, 2 \mathrm{H}), 4.21(\mathrm{q}, J=7.0 \mathrm{~Hz}, 4 \mathrm{H}), 1.51(\mathrm{t}$, $J=7.0 \mathrm{~Hz}, 6 \mathrm{H}) .{ }^{13} \mathrm{C}\left\{{ }^{1} \mathrm{H}\right\}$ NMR $\left(101 \mathrm{MHz}, \mathrm{DCM}-\boldsymbol{d}_{2}\right)$ : Decomposes too quickly to perform this experiment. HRMS (ESI, MeOH/DCM) $\mathbf{m} / \mathbf{z}$ : [6 $\left.\left(\mathrm{O}_{2}\right)_{2}+\mathrm{H}\right]^{+}$Calcd for $\mathrm{C}_{52} \mathrm{H}_{4} \mathrm{~N}_{2} \mathrm{O}_{8}$ 821.2857; Found 821.2854.

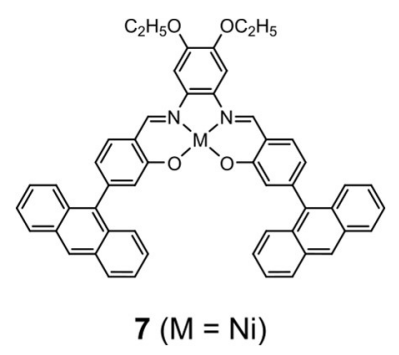

Synthesis of compound 7:

Compound 6 (3.3 mg, $4.3 \mu \mathrm{mol})$ was dissolved in DCM- $d_{2}(600 \mu \mathrm{L})$ in an NMR tube. While heating the tube at $35^{\circ} \mathrm{C}$ in an oil bath, a solution of $\mathrm{Ni}(\mathrm{OAc})_{2} \cdot 4 \mathrm{H}_{2} \mathrm{O}(1.1 \mathrm{mg}, 4.3 \mu \mathrm{mol})$ in methanol- $d_{4}(100 \mu \mathrm{L})$ was added, resulting in a red suspension. Heating at $35{ }^{\circ} \mathrm{C}$ for $16 \mathrm{~h}$ resulted in the formation of dark brown crystals, which were filtered, washed with cold $\mathrm{MeOH}$, and dried in vacuo yielding pure 7 (2.4 mg, $2.9 \mu \mathrm{mol}, 67 \%$ ). A crystal was taken during the filtration step and submitted for SCXRD analysis.

\section{Data for compound 7:}

${ }^{1} \mathrm{H}$ NMR (400 MHz, DMSO- $\left.\mathrm{d}_{6}\right): \delta 8.94(\mathrm{~s}, 2 \mathrm{H}), 8.65(\mathrm{~s}, 2 \mathrm{H}), 8.12(\mathrm{~d}, J=8.4 \mathrm{~Hz}, 2 \mathrm{H}), 7.82(\mathrm{~d}, J=8.3 \mathrm{~Hz}$, 2H), $7.77(\mathrm{~s}, 2 \mathrm{H}), 7.67(\mathrm{~d}, J=8.6 \mathrm{~Hz}, 4 \mathrm{H}), 7.51(\mathrm{t}, J=7.5 \mathrm{~Hz}, 4 \mathrm{H}), 7.45(\mathrm{~d}, J=8.0 \mathrm{~Hz}, 2 \mathrm{H}), 6.81(\mathrm{~s}, 2 \mathrm{H})$, $6.71(\mathrm{~d}, \mathrm{~J}=8.0 \mathrm{~Hz}, 2 \mathrm{H}), 6.54(\mathrm{~s}, 2 \mathrm{H}), 4.23(\mathrm{q}, J=7.0 \mathrm{~Hz}, 4 \mathrm{H}), 1.44(\mathrm{t}, J=6.9 \mathrm{~Hz}, 6 \mathrm{H}) .{ }^{13} \mathrm{C}\left\{{ }^{1} \mathrm{H}\right\} \mathrm{NMR}(101$ MHz, DMSO- $d_{6}$ ): too low solubility for analysis after 10000 scans. HRMS (ESI, MeOH/DCM) $\mathbf{m} / \mathbf{z}$ : [7+H] ${ }^{+}$ Calcd for $\mathrm{C}_{52} \mathrm{H}_{39} \mathrm{~N}_{2} \mathrm{NiO}_{4}$ 813.2263; Found 813.2265. 


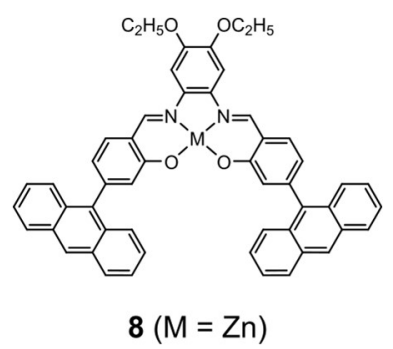

Synthesis of compound 8:

Compound $6(6.8 \mathrm{mg}, 8.9 \mu \mathrm{mol})$ was backfilled with $\mathrm{N}_{2}(\mathrm{x} 3)$, and then degassed $\mathrm{CHCl}_{3}(5 \mathrm{~mL})$ was added. $\mathrm{Zn}\left(\mathrm{O}_{2} \mathrm{C}_{2} \mathrm{~F}_{3}\right)_{2} \cdot \mathrm{xH}_{2} \mathrm{O}(2.9 \mathrm{mg}, 9.8 \mu \mathrm{mol})$ dissolved in $\mathrm{MeOH}(500 \mu \mathrm{L})$ was added with vigorous stirring. The mixture was heated under reflux in an oil bath and stirred in the dark for ca. $18 \mathrm{~h}$, after which it was cooled to room temperature and then stored at $-10^{\circ} \mathrm{C}$ for $24 \mathrm{~h}$. The solid that precipitated was isolated via filtration, washed with cold $\mathrm{MeOH}$, and allowed to dry in vacuo. Compound $\mathbf{8}$ was isolated as a yellow-brown solid (4.2 mg, $5.1 \mu \mathrm{mol}, 57 \%)$.

\section{Data for compound 8:}

${ }^{1} \mathrm{H}$ NMR (400 MHz, DMSO- $\left.d_{6}\right): \delta 9.16(\mathrm{~s}, 2 \mathrm{H}), 8.63(\mathrm{~s}, 2 \mathrm{H}), 8.12(\mathrm{~d}, J=8.4 \mathrm{~Hz}, 4 \mathrm{H}), 7.77$ (d, J = 8.8 Hz, $4 \mathrm{H}), 7.67(\mathrm{~d}, J=8.0 \mathrm{~Hz}, 2 \mathrm{H}), 7.59(\mathrm{~s}, 2 \mathrm{H}), 7.56-7.47(\mathrm{~m}, 4 \mathrm{H}), 7.48-7.39(\mathrm{~m}, 4 \mathrm{H}), 6.69(\mathrm{~s}, 2 \mathrm{H}), 6.55(\mathrm{dd}$, $J=7.9,1.7 \mathrm{~Hz}, 2 \mathrm{H}), 4.26(\mathrm{q}, J=7.0 \mathrm{~Hz}, 4 \mathrm{H}), 1.45(\mathrm{t}, J=6.9 \mathrm{~Hz}, 6 \mathrm{H}) \cdot{ }^{13} \mathrm{C}\left\{{ }^{1} \mathrm{H}\right\}$ NMR $(101 \mathrm{MHz}$, DMSO-d 6 ): ठ 171.6, 161.1, 149.0, 149.0, 144.1, 137.2, 136.3, 133.40, 133.37, 131.4, 129.4, 128.9, 126.7, 126.1, 125.8, 112.0, 116.6, 101.6, 64.9, 15.2. HRMS (ESI, MeOH/DCM) $\mathbf{m} / \mathbf{z}:[8+\mathrm{H}]^{+}$Calcd for $\mathrm{C}_{52} \mathrm{H}_{39} \mathrm{~N}_{2} \mathrm{O}_{4} \mathrm{Zn} 819.2201$; Found 819.2192.<smiles></smiles>

10

Synthesis of compound 10:

9,10-Dibromoanthracene $(1.00 \mathrm{~g}, 3.0 \mathrm{mmol})$, bis(pinacolato)diboron $(1.89 \mathrm{~g}, 7.44 \mathrm{mmol}), \mathrm{Pd}(\mathrm{OAc})_{2}(100$ $\mathrm{mg}, 455 \mu \mathrm{mol})$, and KOAc (1.75 g, $17.8 \mathrm{mmol})$ were combined in an oven-dried Schlenk flask and backfilled with $\mathrm{N}_{2}(\mathrm{x} 3)$. After this, dry DMF $(40 \mathrm{~mL})$ was added and the mixture was heated at $100^{\circ} \mathrm{C}$ in an oil bath for $17 \mathrm{~h}$ in the dark. The solution was poured into brine $(100 \mathrm{~mL})$, extracted with $\mathrm{PhMe}(3 \times 40 \mathrm{~mL})$, and the combined organic layers were dried with $\mathrm{MgSO}_{4}$, filtered, and the solvent was removed in vacuo. The resulting brown oil was purified by silica column chromatography (DCM/hexanes, $\left.1: 1, R_{f}=0.25\right)$ to yield compound 10 (682 mg, $1.6 \mathrm{mmol}, 53 \%$ ) as a white crystalline solid. ${ }^{3}$

Data for compound 10:

${ }^{1} \mathrm{H}$ NMR (400 MHz, $\mathrm{CDCl}_{3}$ ): $\delta 8.34$ (dd, $\left.J=6.7,3.3 \mathrm{~Hz}, 4 \mathrm{H}\right), 7.45$ (dd, $\left.J=6.8,3.3 \mathrm{~Hz}, 4 \mathrm{H}\right), 1.58(\mathrm{~s}, 24 \mathrm{H})$. ${ }^{13} \mathrm{C}\left\{{ }^{1} \mathrm{H}\right\}$ NMR (101 MHz, $\mathrm{CDCl}_{3}$ ): $\delta$ 135.1, 129.0, 125.4, 84.7, 25.4 (C attached to BPin group not seen). LRMS (ESI, MeOH/DCM) m/z: [10+Na] ${ }^{+}$Calcd for $\mathrm{C}_{26} \mathrm{H}_{32} \mathrm{~B}_{2} \mathrm{O}_{4} \mathrm{Na}$ 453.2; Found 453.3. Spectral data matched previous reports. ${ }^{3}$ 


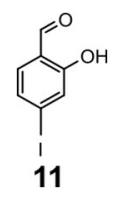

Synthesis of compound 11:

3-lodophenol (10.0 g, $45 \mathrm{mmol})$ was dissolved in MeCN (150 mL) in an over-dried round-bottomed flask. The solution was cooled to $0^{\circ} \mathrm{C}$, and slowly $\mathrm{MgCl}_{2}$ (anhydrous, $12.8 \mathrm{~g}, 134 \mathrm{mmol}$ ) was added over 15 mins. $\mathrm{NEt}_{3}(26 \mathrm{~mL}, 186 \mathrm{mmol})$ was added dropwise, followed by paraformaldehyde $(5.47 \mathrm{~g}, 182 \mathrm{mmol})$. The mixture was then heated to $80^{\circ} \mathrm{C}$ in an oil bath and stirred at that temperature for $18 \mathrm{~h}$. The solution was slowly quenched with $\mathrm{HCl}_{(\mathrm{aq})}(5 \mathrm{M}, 100 \mathrm{~mL})$ then extracted with EtOAc $(3 \times 50 \mathrm{~mL})$. The combined organic fractions were dried with $\mathrm{MgSO}_{4}$, filtered, and the solvent was removed in vacuo. The brown oil obtained was purified by silica column chromatography (AcOEt/Hexanes, 1:5, $R_{f}=0.25$ ) to yield compound $11(2.40$ g, $9.7 \mathrm{mmol}, 22 \%$ ) as a white crystalline solid. ${ }^{4}$ Alternate purification: recrystallization from hot hexanes.

\section{Data for compound 11:}

${ }^{1} \mathrm{H}$ NMR (400 MHz, CDCl $)$ : $\delta 11.02(\mathrm{~s}, 1 \mathrm{H}), 9.85(\mathrm{~s}, 1 \mathrm{H}), 7.44(\mathrm{~d}, J=1.5 \mathrm{~Hz}, 1 \mathrm{H}), 7.40(\mathrm{dd}, J=8.1,1.5 \mathrm{~Hz}$, $1 \mathrm{H}), 7.23(\mathrm{~d}, J=8.1 \mathrm{~Hz}, 1 \mathrm{H}) \cdot{ }^{13} \mathrm{C}\left\{{ }^{1} \mathrm{H}\right\}$ NMR $\left(101 \mathrm{MHz}, \mathrm{CDCl}_{3}\right): \delta 196.4,161.6,134.5,129.7,127.6,120.3$, 105.5. ${ }^{4}$ HRMS (ESI, MeOH/DCM) $\mathbf{m} / \mathbf{z}$ : [11+H] ${ }^{+}$Calcd for $\mathrm{C}_{7} \mathrm{H}_{4} \mathrm{IO}_{2}$ 246.9261; Found 246.9259. Spectral data matched previous reports. ${ }^{4}$

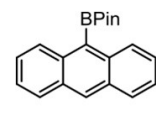

13

\section{Synthesis of compound 13:}

Compound 12 (1.00 g, $3.9 \mathrm{mmol})$, bis(pinacolato)diboron (1.23 g, $4.8 \mathrm{mmol}), \mathrm{Pd}(\mathrm{OAc})_{2}(87 \mathrm{mg}, 390 \mu \mathrm{mol})$, and KOAc (1.15 g, $11.7 \mathrm{mmol})$ were combined in an oven-dried Schlenk flask and backfilled with $\mathrm{N}_{2}(\mathrm{x} 3)$. Afterward, dry DMF (40 mL) was added, and the mixture was heated at $100^{\circ} \mathrm{C}$ in an oil bath for $48 \mathrm{~h}$ in the dark. The product was poured into brine $(100 \mathrm{~mL})$ and extracted with PhMe $(3 \times 50 \mathrm{~mL})$, and the combined organic fractions were dried with $\mathrm{MgSO}_{4}$, filtered, and the solvent was removed in vacuo. The crude brown oil was purified by recrystallization (EtOH) to yield compound 13 (869 mg, $2.9 \mathrm{mmol}, 73 \%$ ) as a light brown solid. ${ }^{3}$

\section{Data for compound 13:}

${ }^{1} \mathrm{H}$ NMR (400 MHz, $\left.\mathrm{CDCl}_{3}\right): \delta 8.48(\mathrm{~s}, 1 \mathrm{H}), 8.45(\mathrm{~d}, J=8.8 \mathrm{~Hz}, 2 \mathrm{H}), 7.99(\mathrm{~d}, J=7.4 \mathrm{~Hz}, 2 \mathrm{H}), 7.60-7.41$ $(\mathrm{m}, 4 \mathrm{H}), 1.58(\mathrm{~s}, 12 \mathrm{H}) .{ }^{3}{ }^{13} \mathrm{C}\left\{{ }^{1} \mathrm{H}\right\} \mathrm{NMR}\left(101 \mathrm{MHz}, \mathrm{CDCl}_{3}\right): \delta$ 136.1, 131.3, 129.6, 129.0, 128.5, 125.9, 125.03, 84.5, 25.4 (C attached to BPin group not seen). LRMS (ESI, MeOH/DCM) $\mathbf{m} / \mathbf{z}:[13+\mathrm{H}]^{+}$Calcd for $\mathrm{C}_{20} \mathrm{H}_{22} \mathrm{BO}_{2}$ 305.3; Found 305.2. Spectral data matched previous reports. ${ }^{3}$ 
NMR Spectra and Experiments

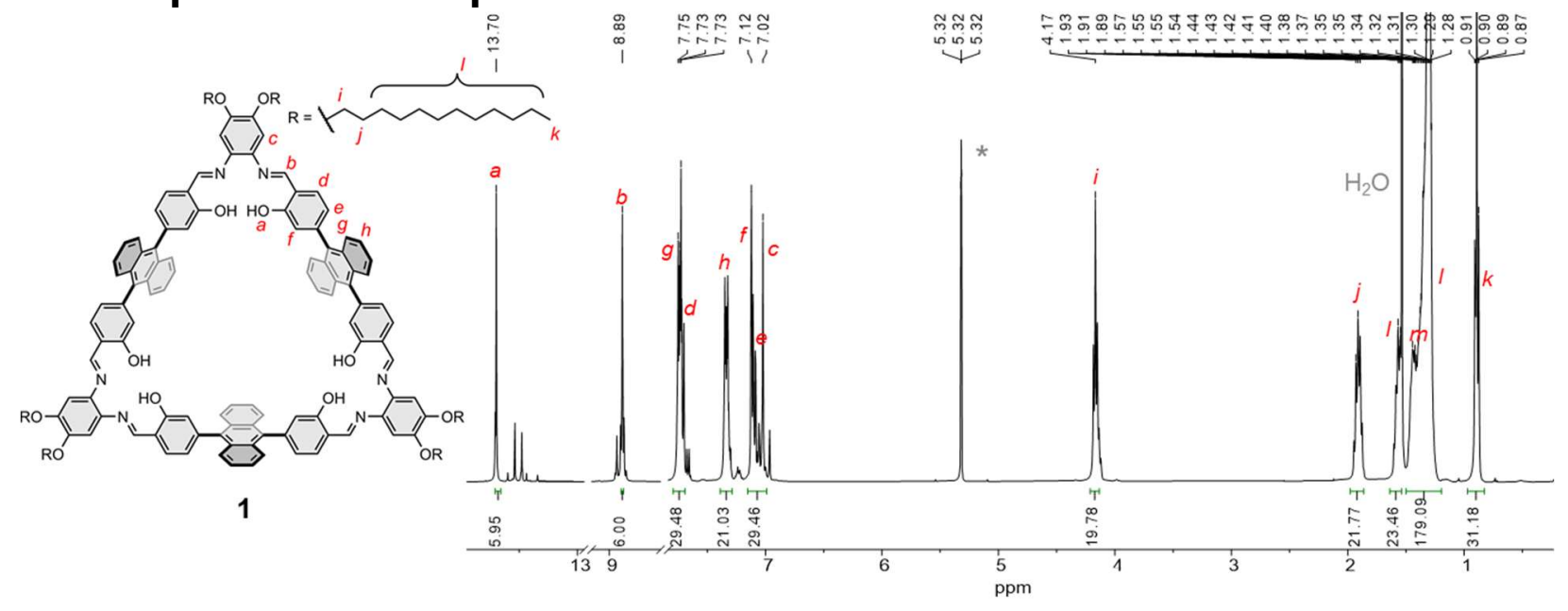

Figure S1. ${ }^{1} \mathrm{H}$ NMR spectrum $\left(400 \mathrm{MHz}, 25^{\circ} \mathrm{C}, \mathrm{DCM}-\mathrm{d}_{2}\right)$ of compound 1. (Integrations are off due to overlapping signals).

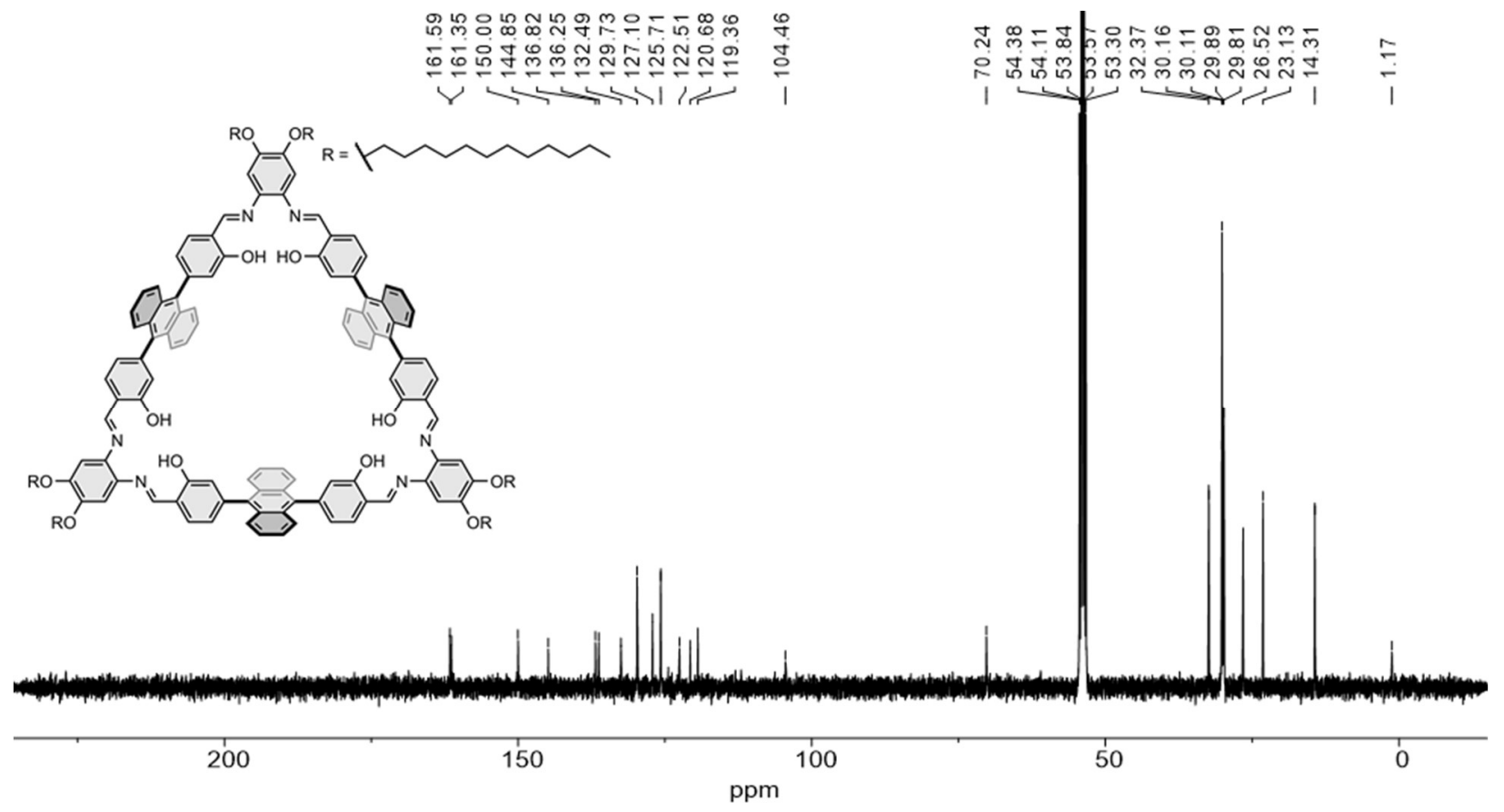

Figure S2. ${ }^{13} \mathrm{C}\left\{{ }^{1} \mathrm{H}\right\}$ NMR spectrum $\left(101 \mathrm{MHz}, 25^{\circ} \mathrm{C}, \mathrm{DCM}-d_{2}\right)$ of compound 1. 


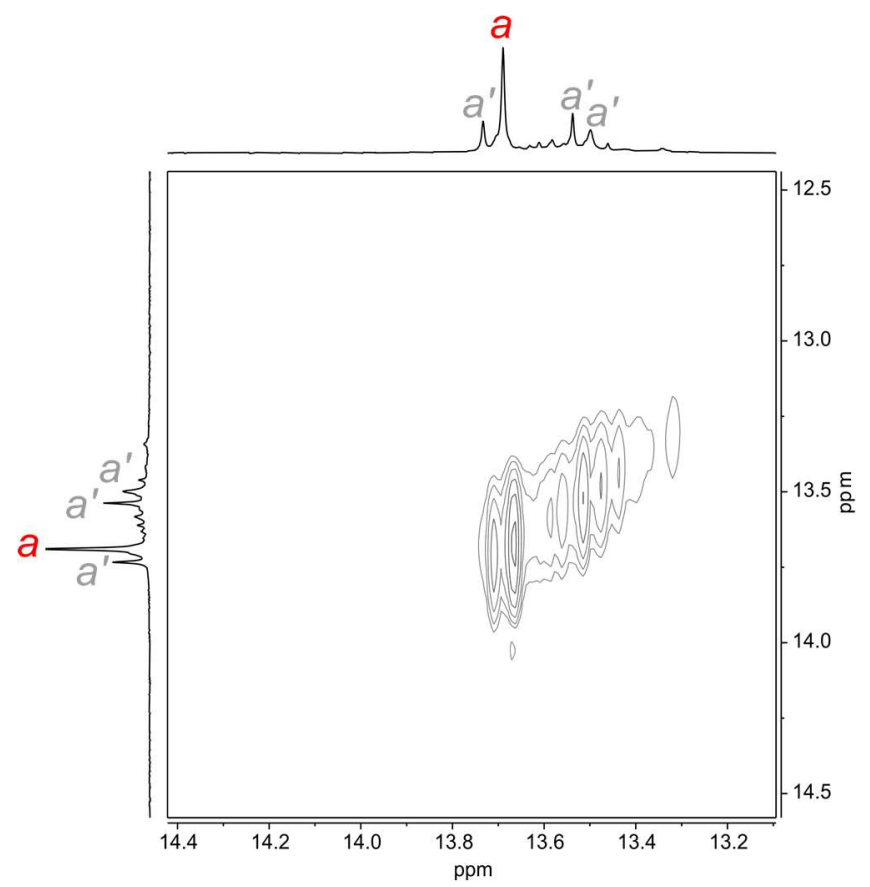

Figure S3. ${ }^{1} \mathrm{H}-{ }^{1} \mathrm{H}$ NOESY $\left(600 \mathrm{MHz}, 25^{\circ} \mathrm{C}, \mathrm{DCM}-d_{2}\right)$ spectrum for 1 highlighting resonance $a$.

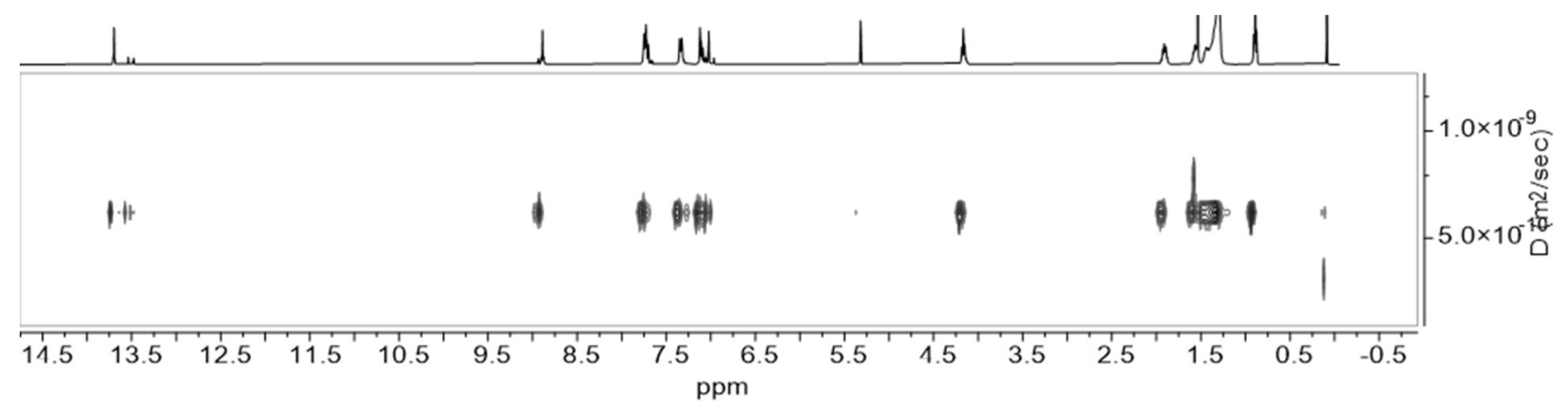

Figure S4. DOSY spectrum $\left(400 \mathrm{MHz}, 25^{\circ} \mathrm{C}, \mathrm{DCM}-d_{2}\right)$ of 1. 


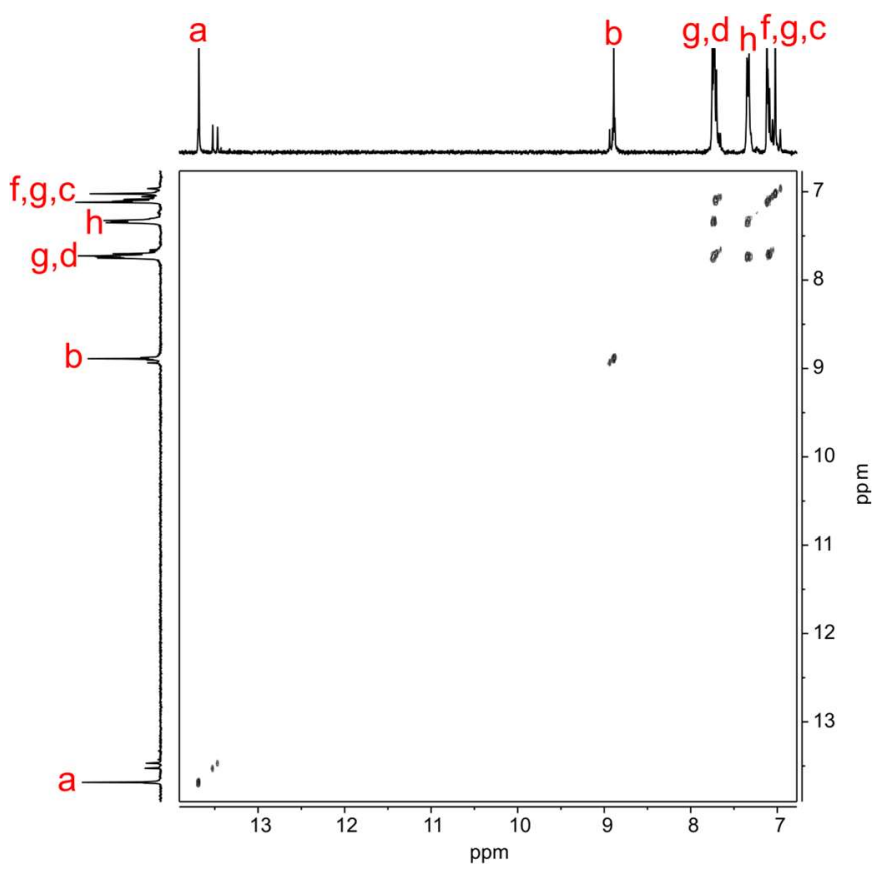

Figure S5. Partial ${ }^{1} \mathrm{H}-{ }^{1} \mathrm{H}$ COSY NMR (400 MHz, $\left.25^{\circ} \mathrm{C}, \mathrm{DCM}-d_{2}\right)$ spectrum for 1 (aromatic region).

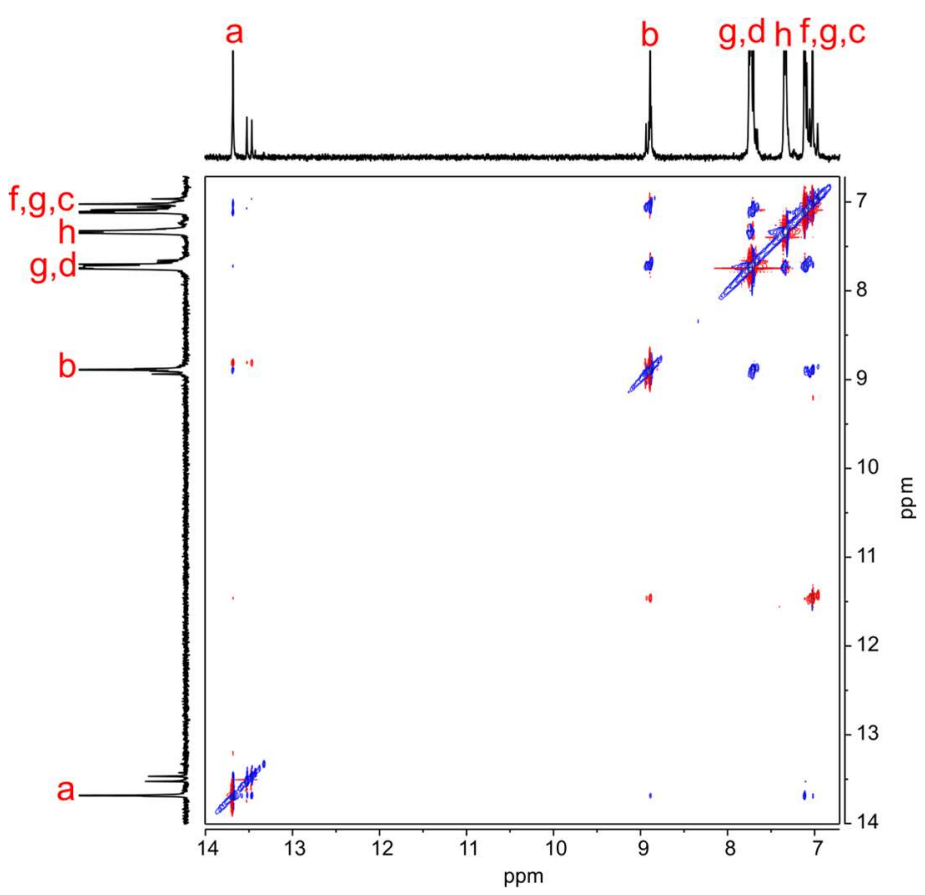

Figure S6. Partial ${ }^{1} \mathrm{H}-{ }^{1} \mathrm{H}$ NOESY $\left(400 \mathrm{MHz}, 25^{\circ} \mathrm{C}, \mathrm{DCM}-d_{2}\right)$ spectrum for 1 (aromatic region). 


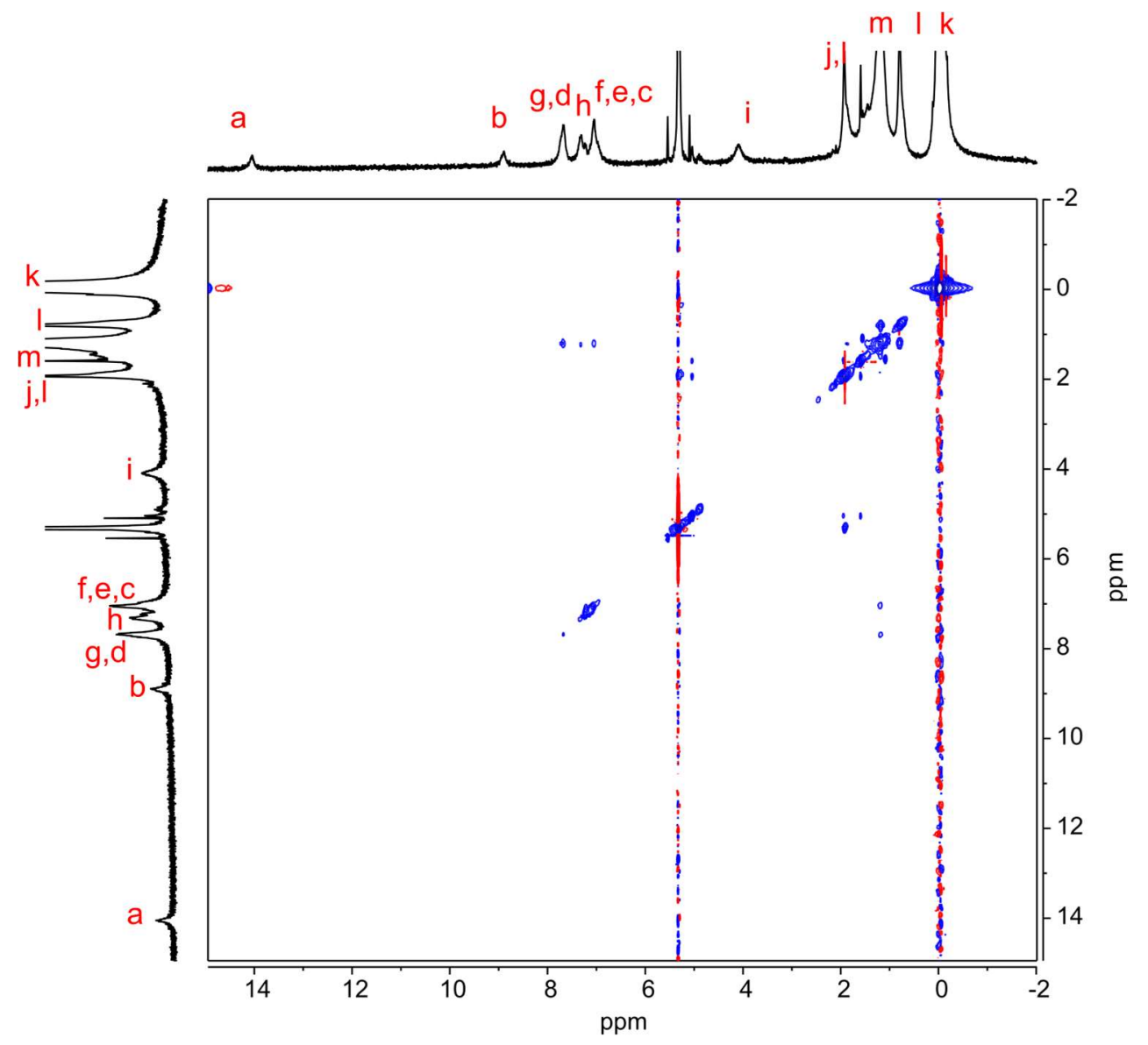

Figure S7. ${ }^{1} \mathrm{H}-{ }^{1} \mathrm{H}$ NOESY $\left(400 \mathrm{MHz},-80^{\circ} \mathrm{C}, \mathrm{DCM}-d_{2}\right)$ spectrum for 1 (aromatic region). 


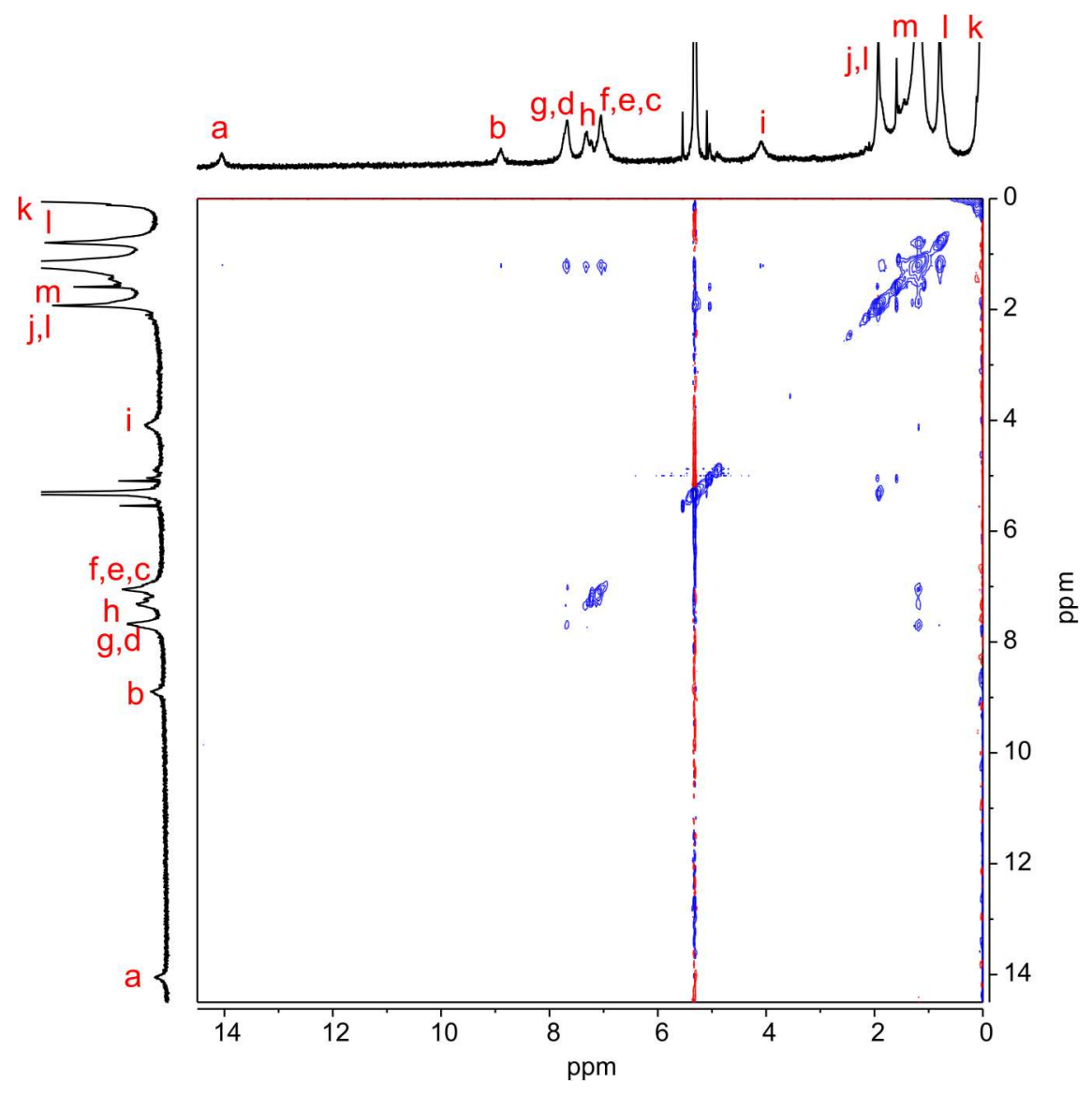

Figure S8. ${ }^{1} \mathrm{H}-{ }^{1} \mathrm{H}$ ROESY $\left(400 \mathrm{MHz},-80^{\circ} \mathrm{C}, \mathrm{DCM}-d_{2}\right)$ spectrum for 1 (aromatic region). 


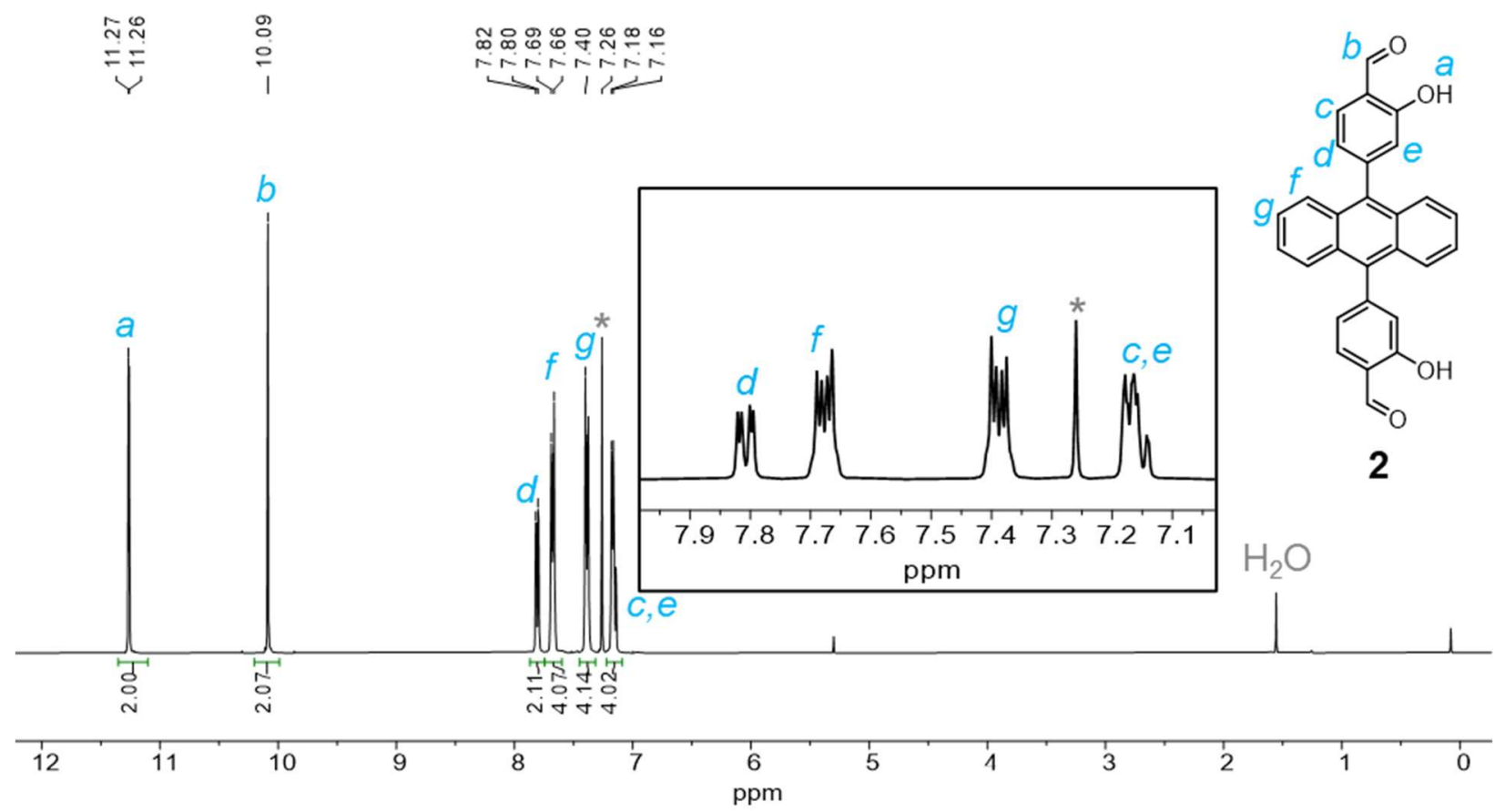

Figure S9. ${ }^{1} \mathrm{H}$ NMR spectrum $\left(400 \mathrm{MHz}, 25^{\circ} \mathrm{C}, \mathrm{CDCl}_{3}\right)$ of compound 2.

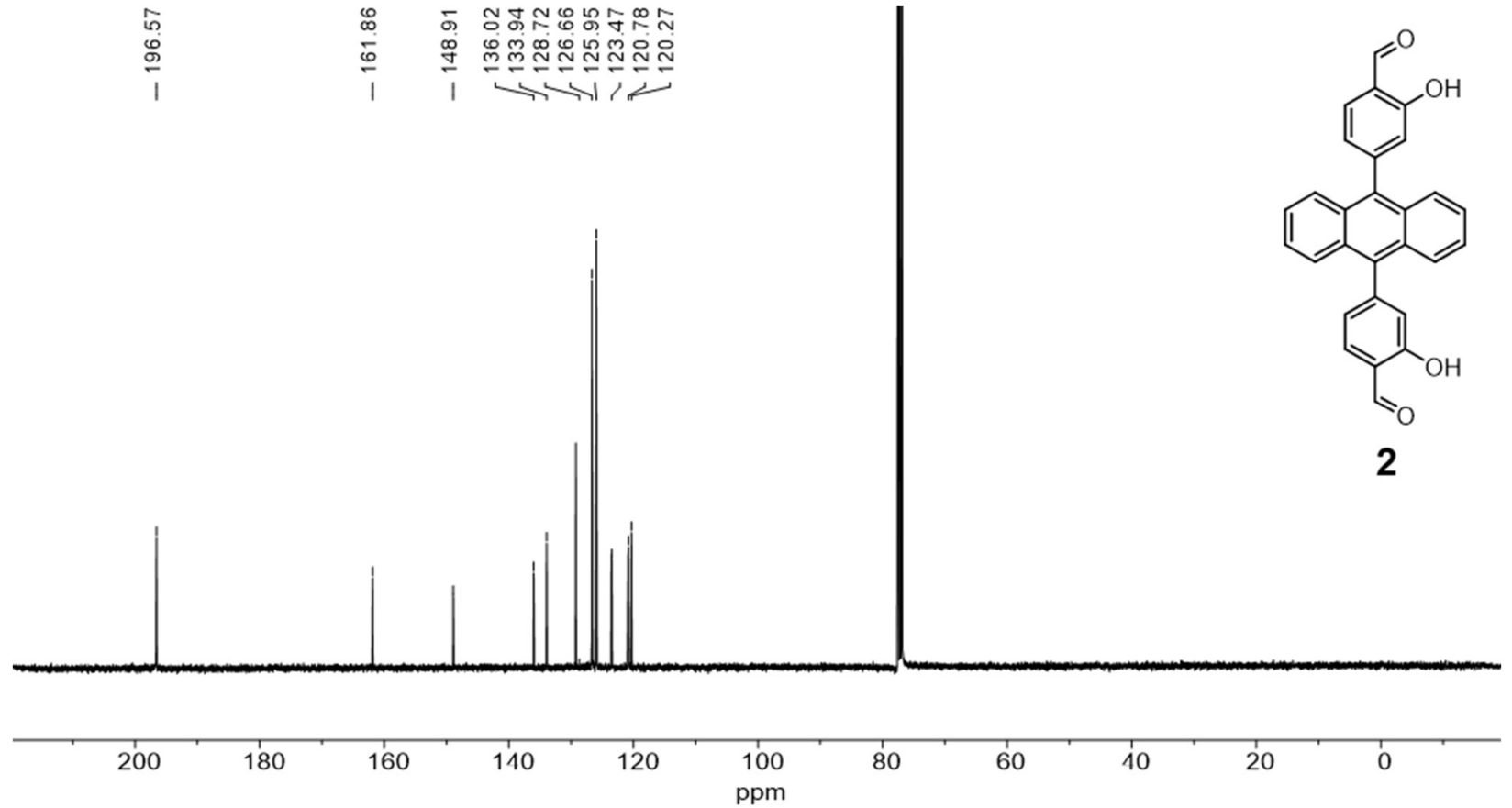

Figure $\mathrm{S} 10 .{ }^{13} \mathrm{C}\left\{{ }^{1} \mathrm{H}\right\}$ NMR spectrum $\left(101 \mathrm{MHz}, 25^{\circ} \mathrm{C}, \mathrm{CDCl}_{3}\right)$ of compound 2. 


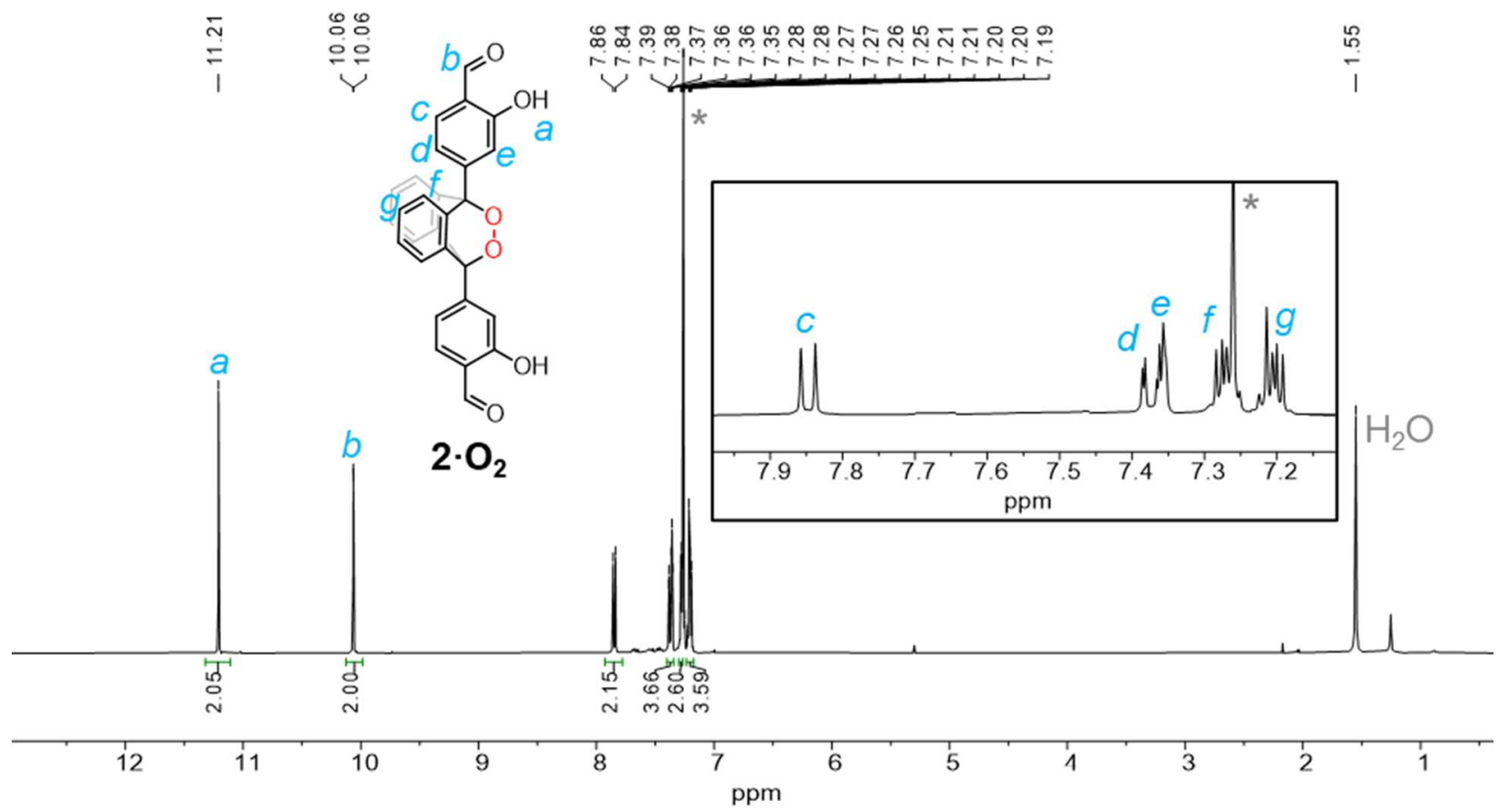

Figure $\mathrm{S} 11 .{ }^{1} \mathrm{H}$ NMR spectrum $\left(400 \mathrm{MHz}, 25^{\circ} \mathrm{C}, \mathrm{CDCl}_{3}\right)$ of compound $2 \cdot \mathrm{O}_{2}$.

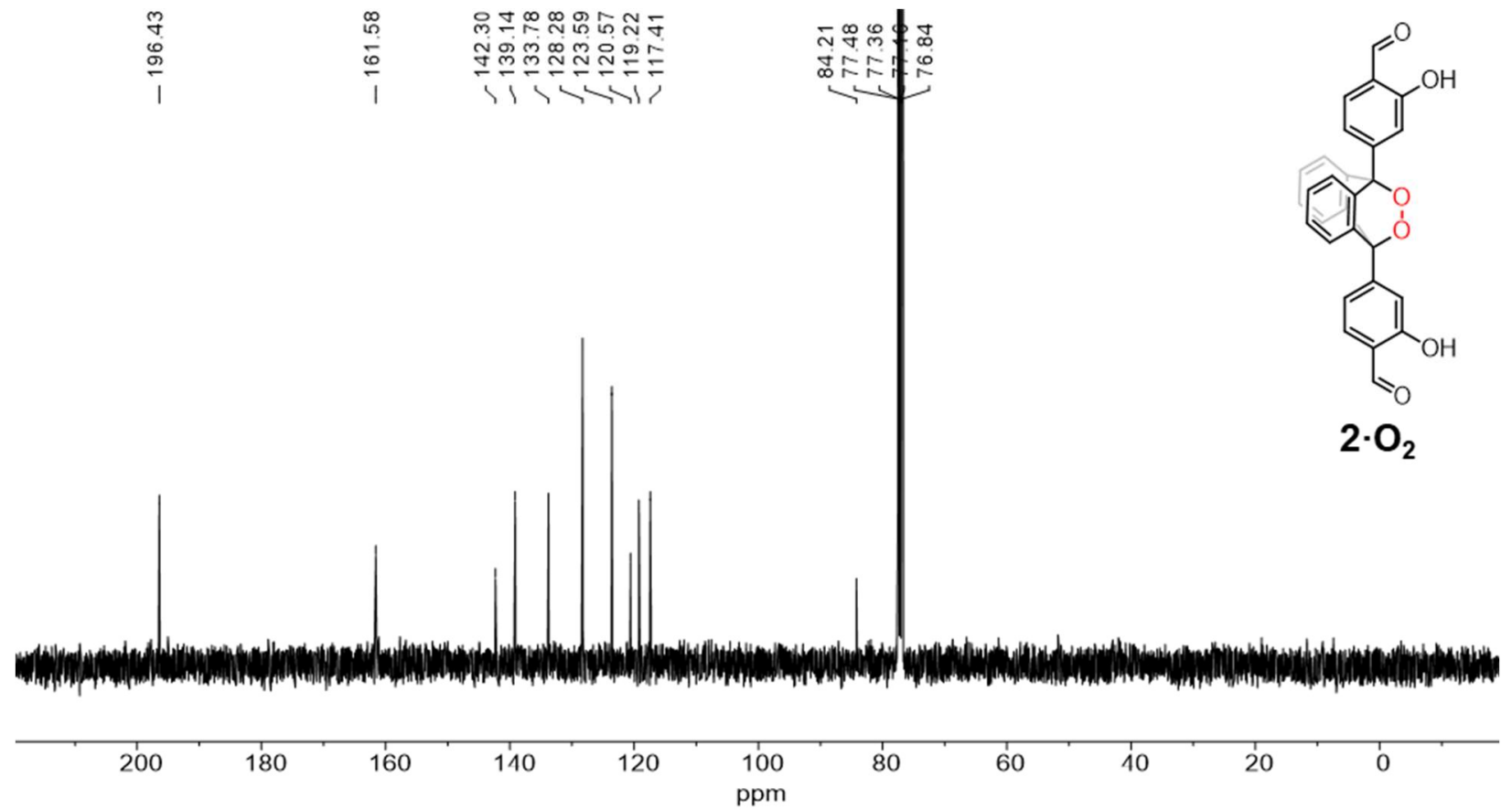

Figure $\mathrm{S} 12 .{ }^{13} \mathrm{C}\left\{{ }^{1} \mathrm{H}\right\} \mathrm{NMR}$ spectrum $\left(101 \mathrm{MHz}, 25^{\circ} \mathrm{C}, \mathrm{CDCl}_{3}\right)$ of compound $\mathbf{2} \cdot \mathrm{O}_{2}$. 

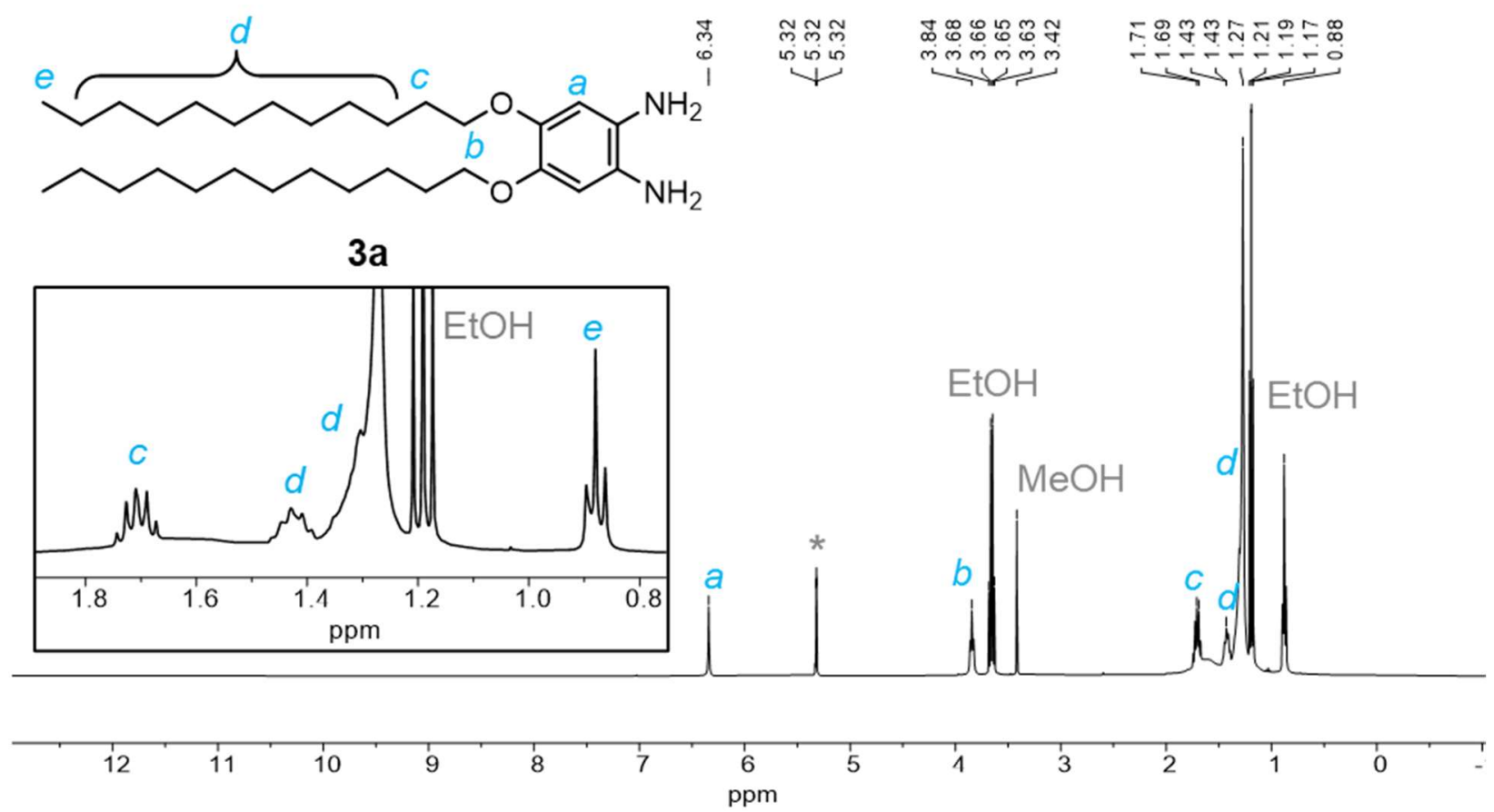

Figure $\mathrm{S} 13 .{ }^{1} \mathrm{H}$ NMR spectrum $\left(400 \mathrm{MHz}, 25^{\circ} \mathrm{C}, \mathrm{DCM}-d_{2}\right)$ of compound $3 \mathrm{a}$.

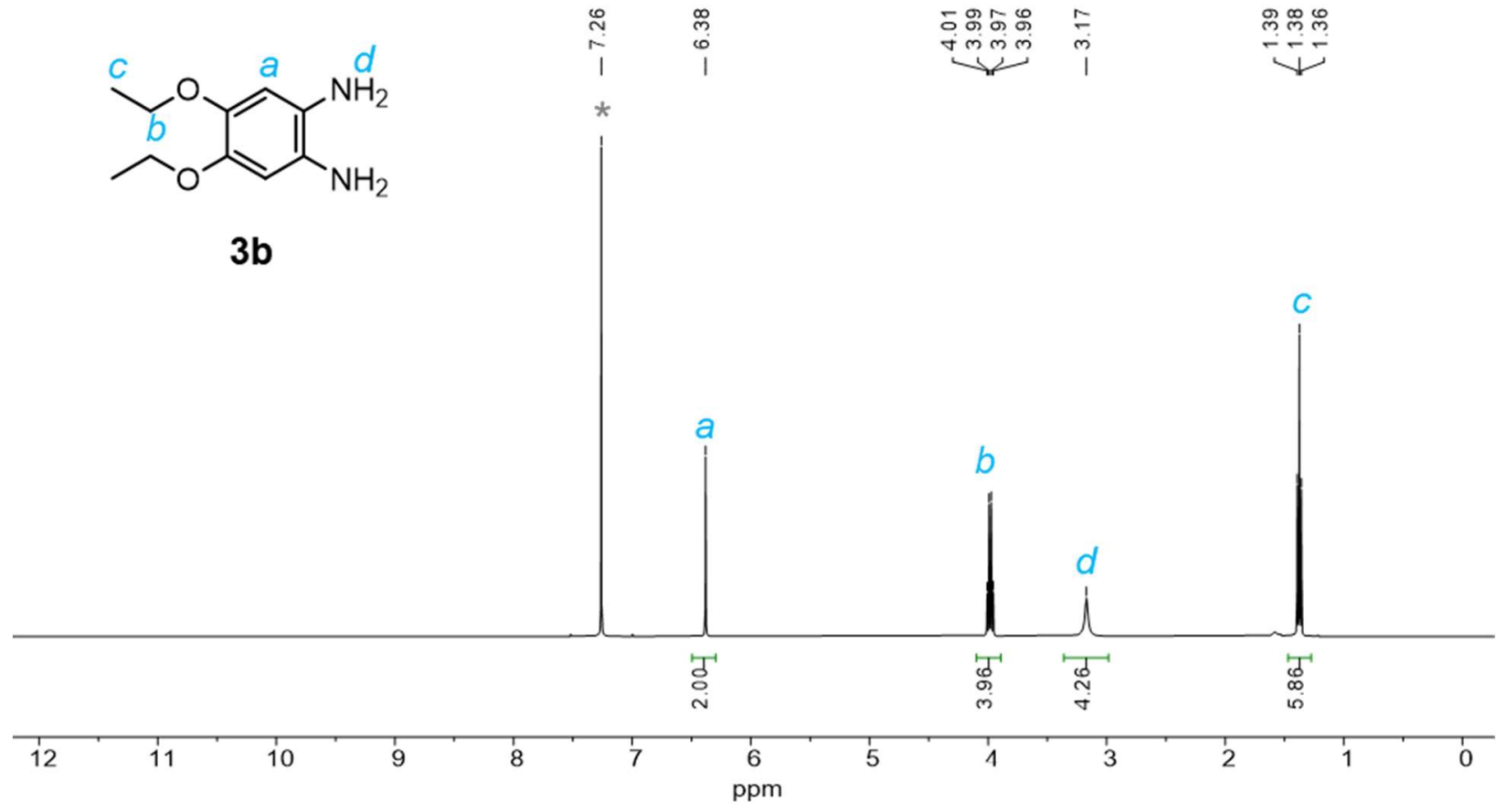

Figure $\mathrm{S} 14 .{ }^{1} \mathrm{H}$ NMR spectrum $\left(400 \mathrm{MHz}, 25^{\circ} \mathrm{C}, \mathrm{CDCl}_{3}\right)$ of compound $\mathbf{3 b}$. 


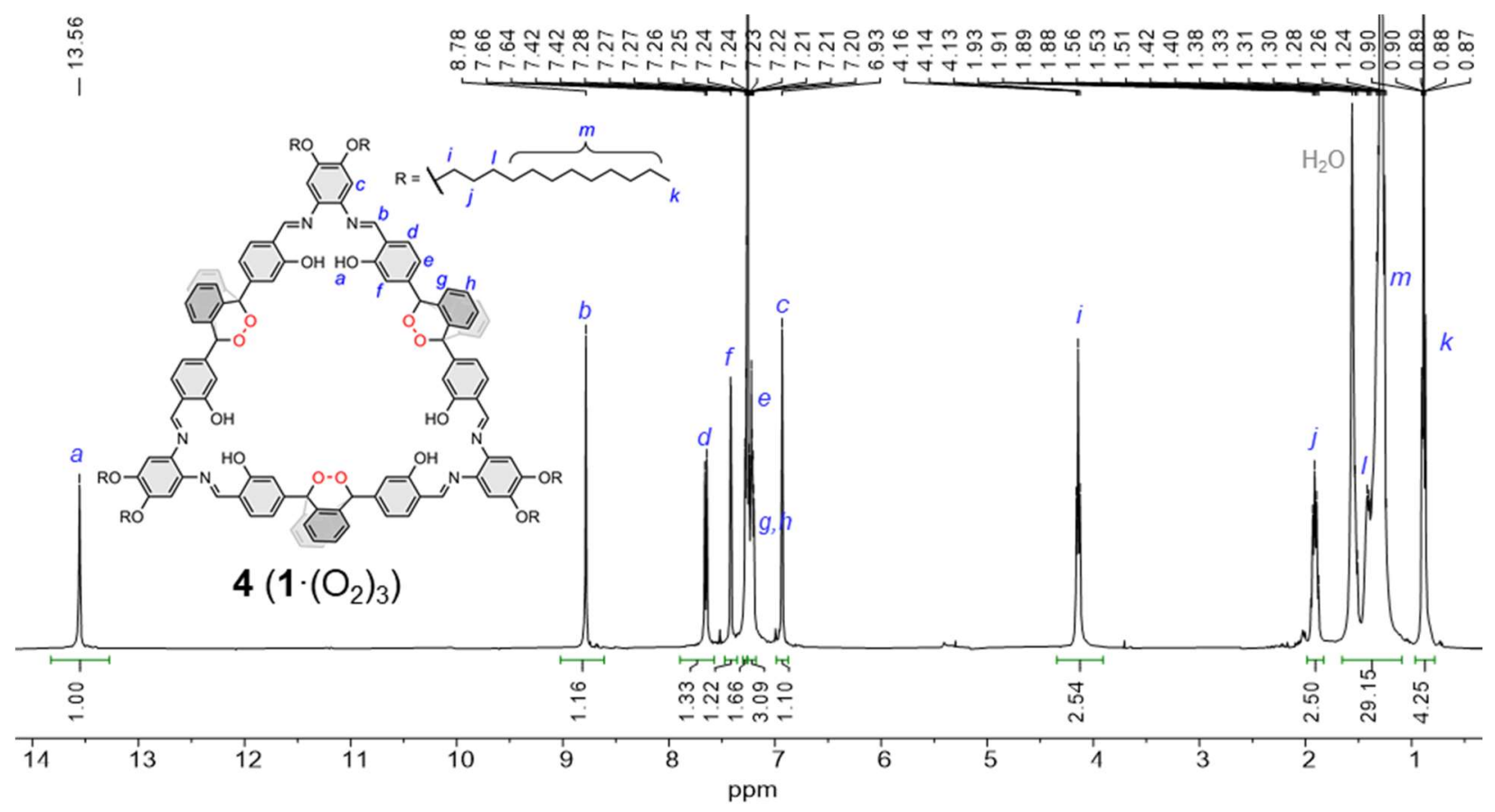

Figure S15. ${ }^{1} \mathrm{H}$ NMR spectrum $\left(400 \mathrm{MHz}, 25^{\circ} \mathrm{C}, \mathrm{CDCl}_{3}\right)$ of compound 4.
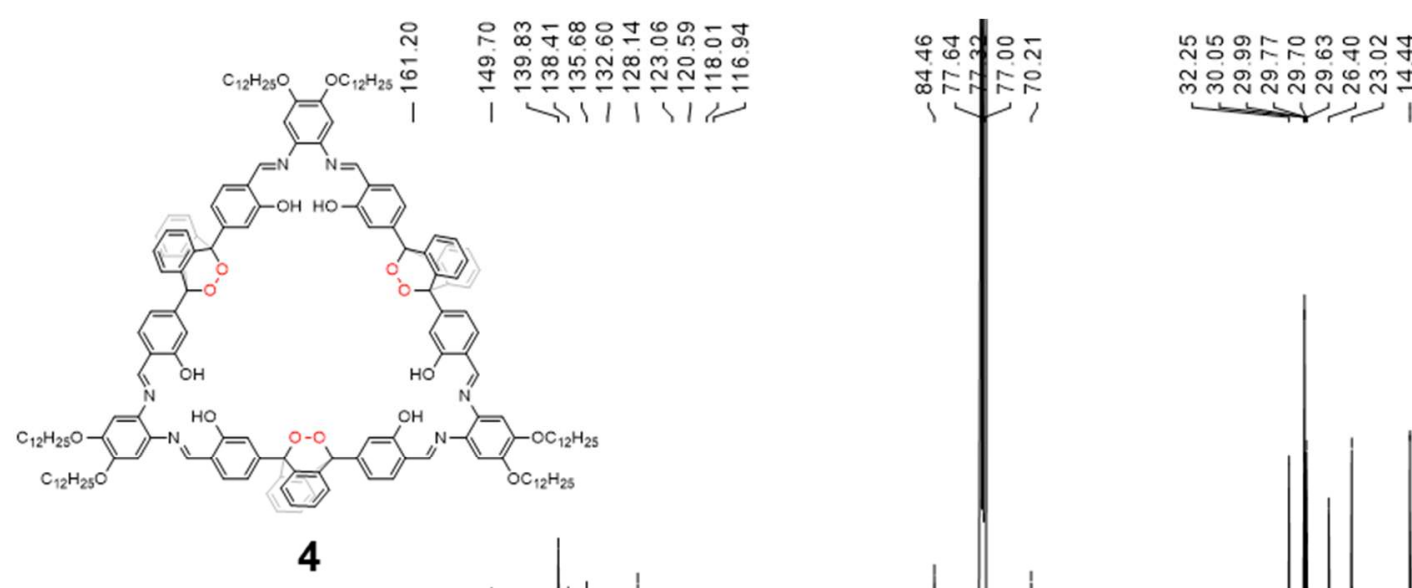

m ల్లిల్లి

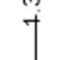

$200-180,160,140,120$

100
ppm

80

60

40

20

Figure $\mathrm{S} 16 .{ }^{13} \mathrm{C}\left\{{ }^{1} \mathrm{H}\right\} \mathrm{NMR}$ spectrum $\left(101 \mathrm{MHz}, 25^{\circ} \mathrm{C}, \mathrm{CDCl}_{3}\right)$ of compound 4. 

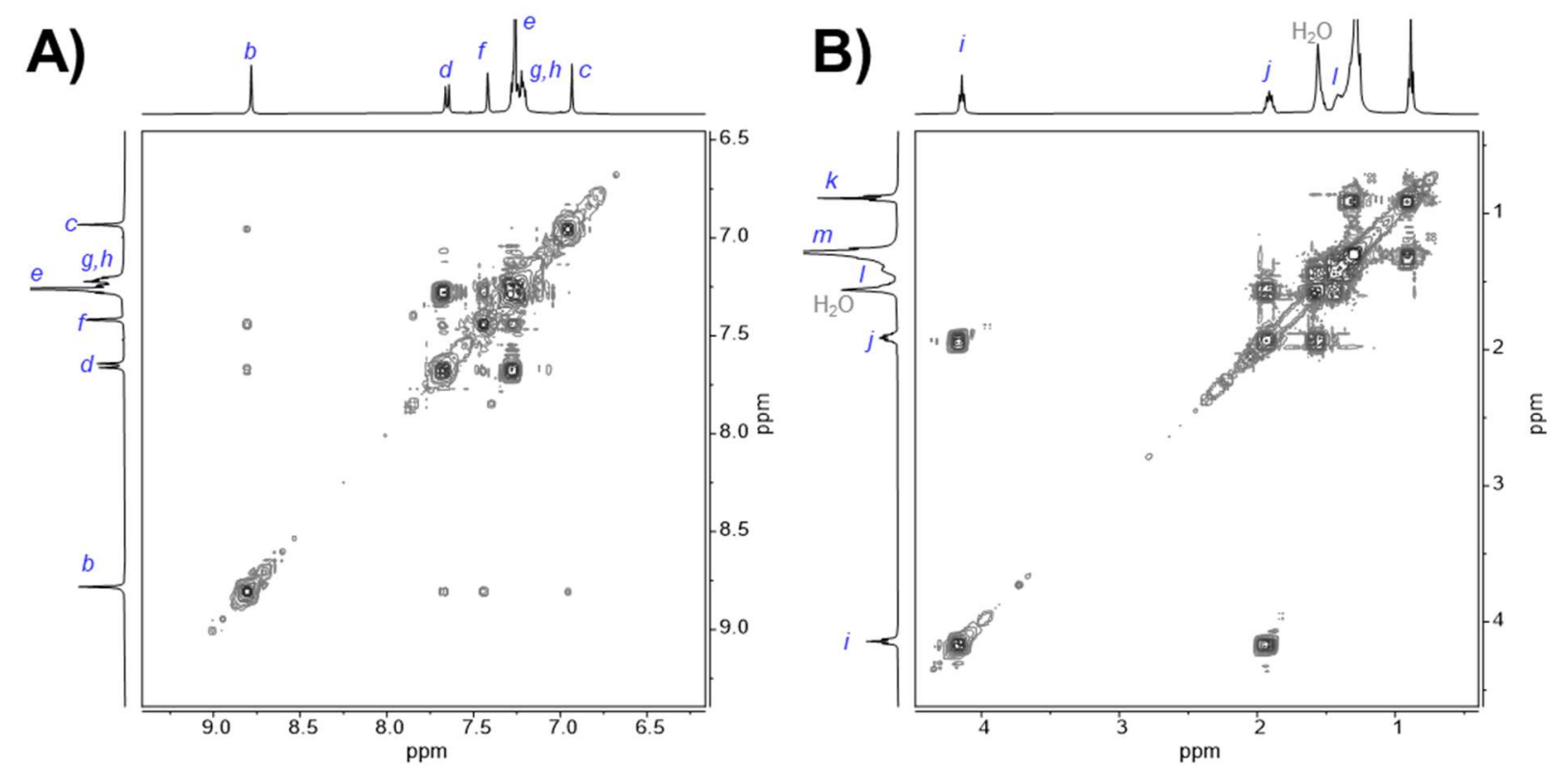

Figure S17. ${ }^{1} \mathrm{H}-{ }^{1} \mathrm{H}$ COSY NMR spectrum $\left(400 \mathrm{MHz}, 25^{\circ} \mathrm{C}, \mathrm{CDCl}_{3}\right)$ of compound 4. A) aromatic region, and $\mathrm{B}$ ) aliphatic region.
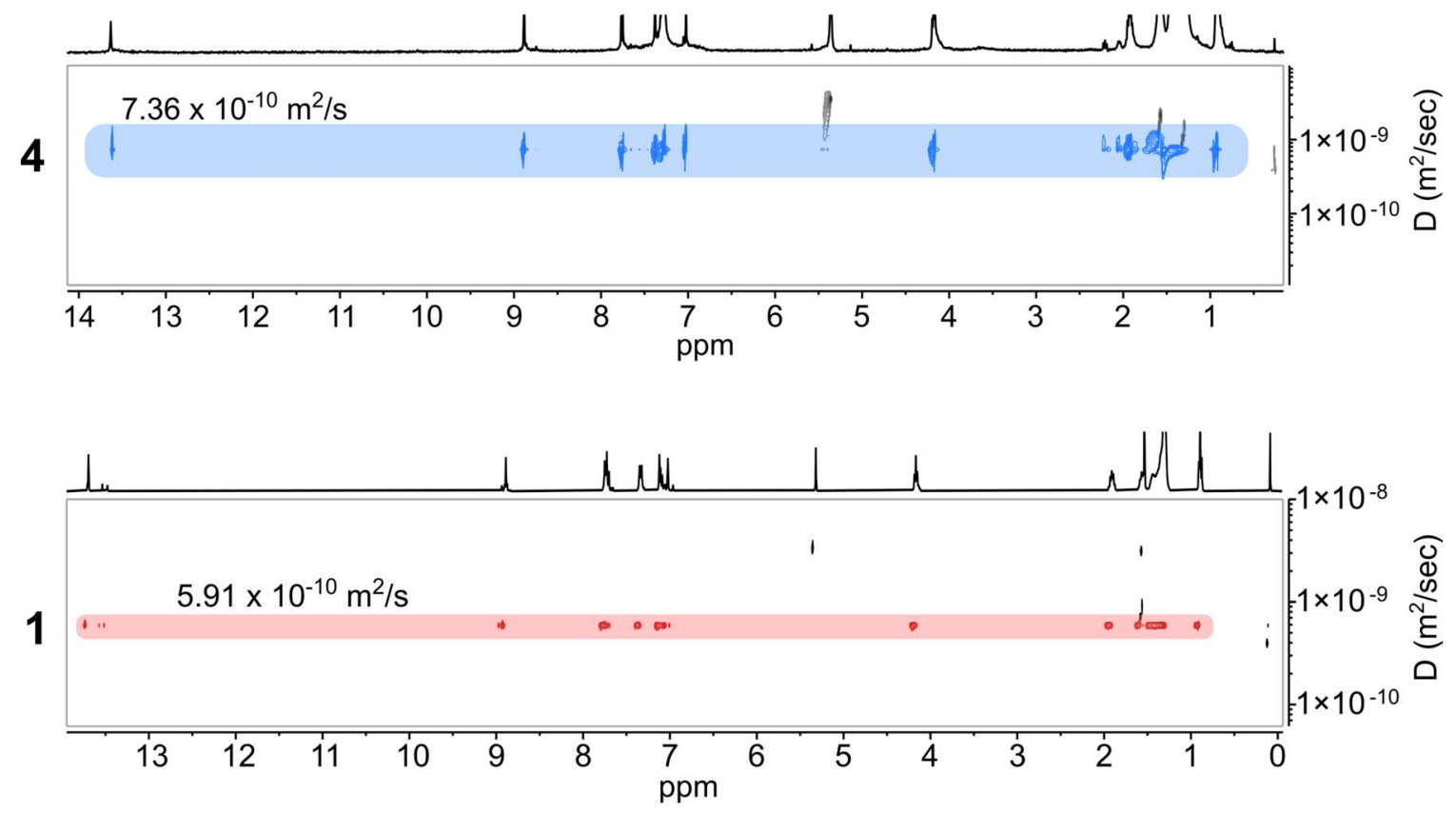

Figure S18. Stacked DOSY NMR spectra ( $\left.400 \mathrm{MHz}, 25^{\circ} \mathrm{C}, \mathrm{DCM}-d_{2}\right)$ of (top) 4 and (bottom) 1. 


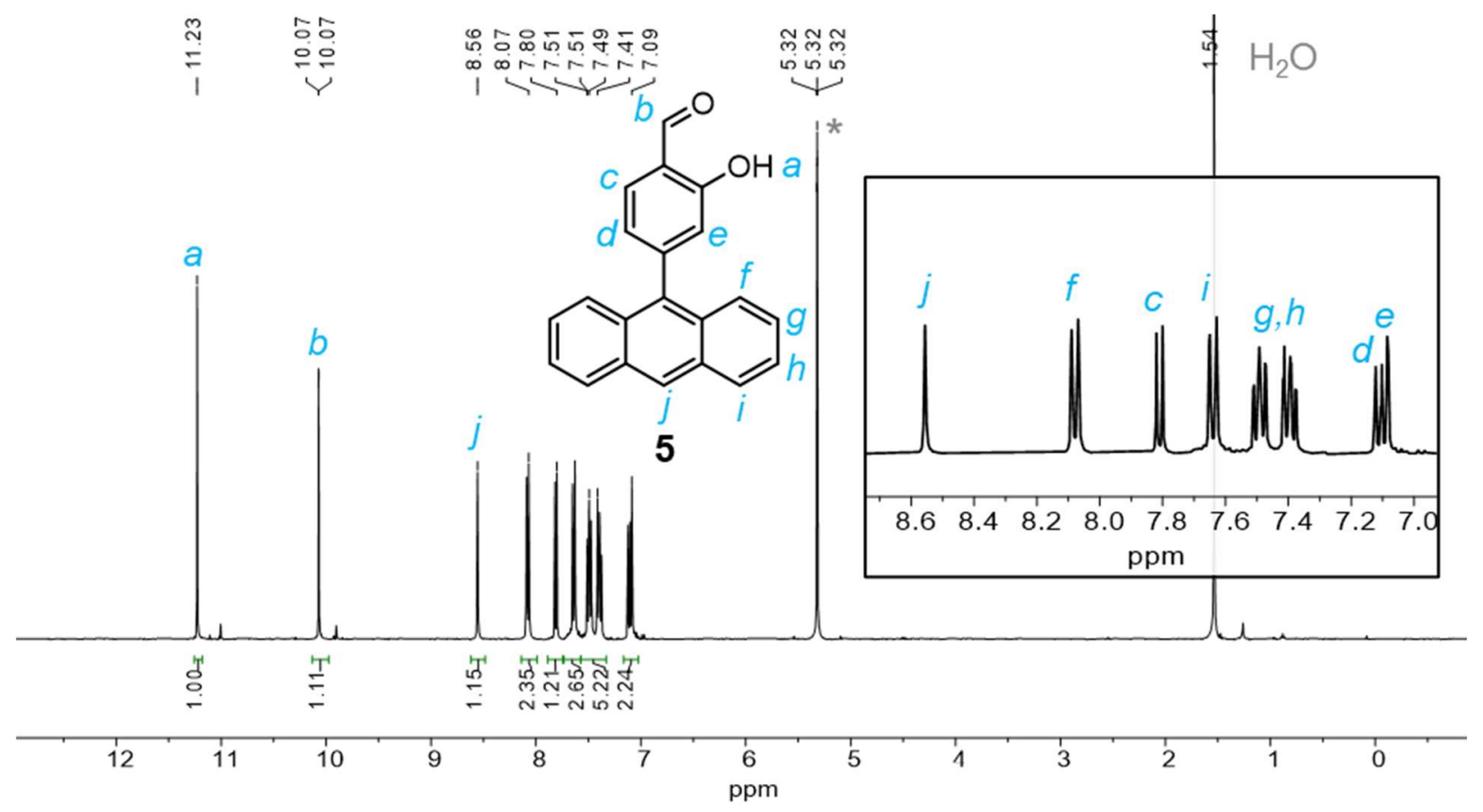

Figure S19. ${ }^{1} \mathrm{H}$ NMR spectrum $\left(400 \mathrm{MHz}, 25^{\circ} \mathrm{C}, \mathrm{DCM}-d_{2}\right)$ of compound 5.

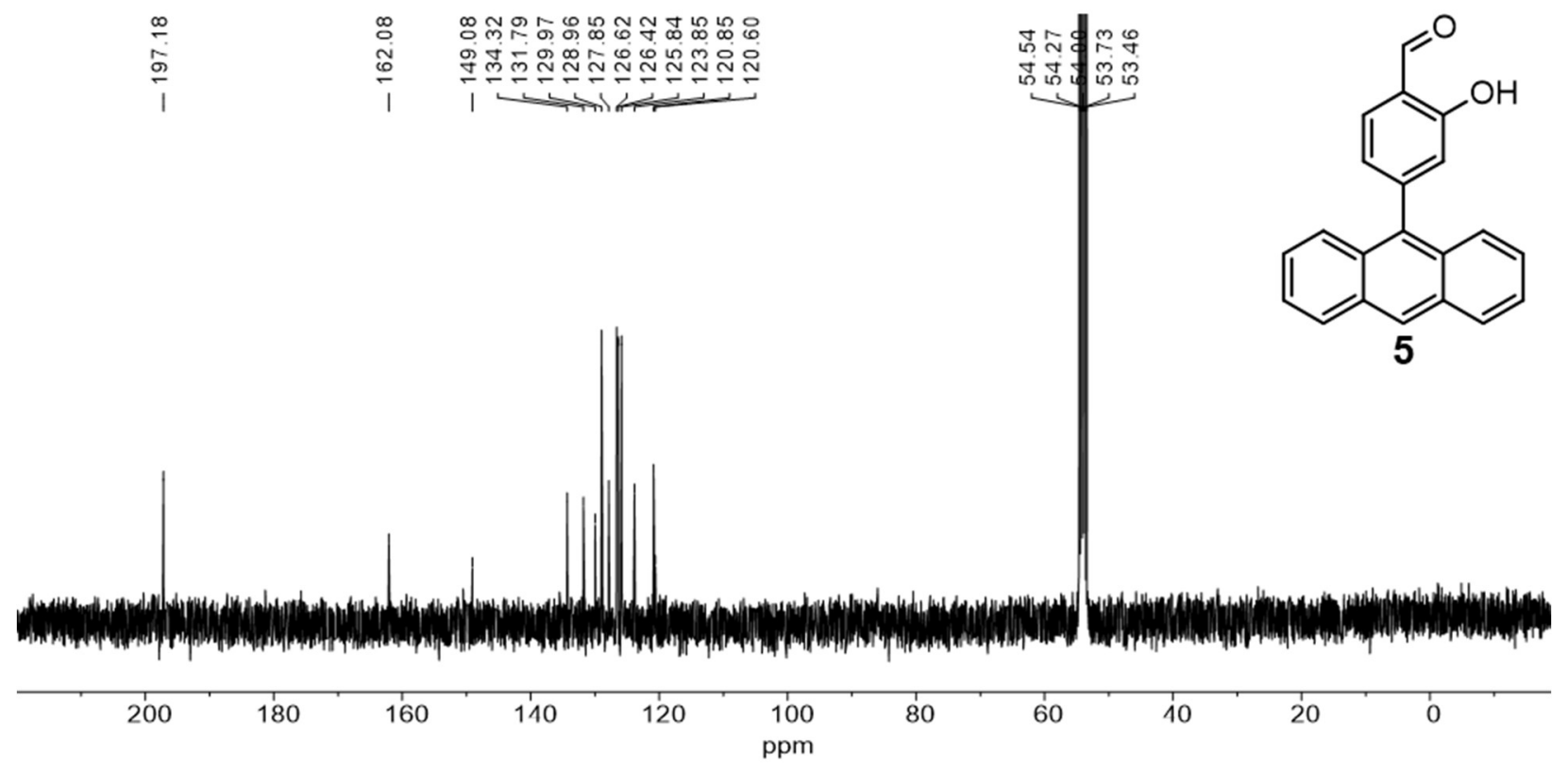

Figure S20. ${ }^{13} \mathrm{C}\left\{{ }^{1} \mathrm{H}\right\}$ NMR spectrum $\left(101 \mathrm{MHz}, 25^{\circ} \mathrm{C}, \mathrm{DCM}-d_{2}\right)$ of compound $\mathbf{5}$. 


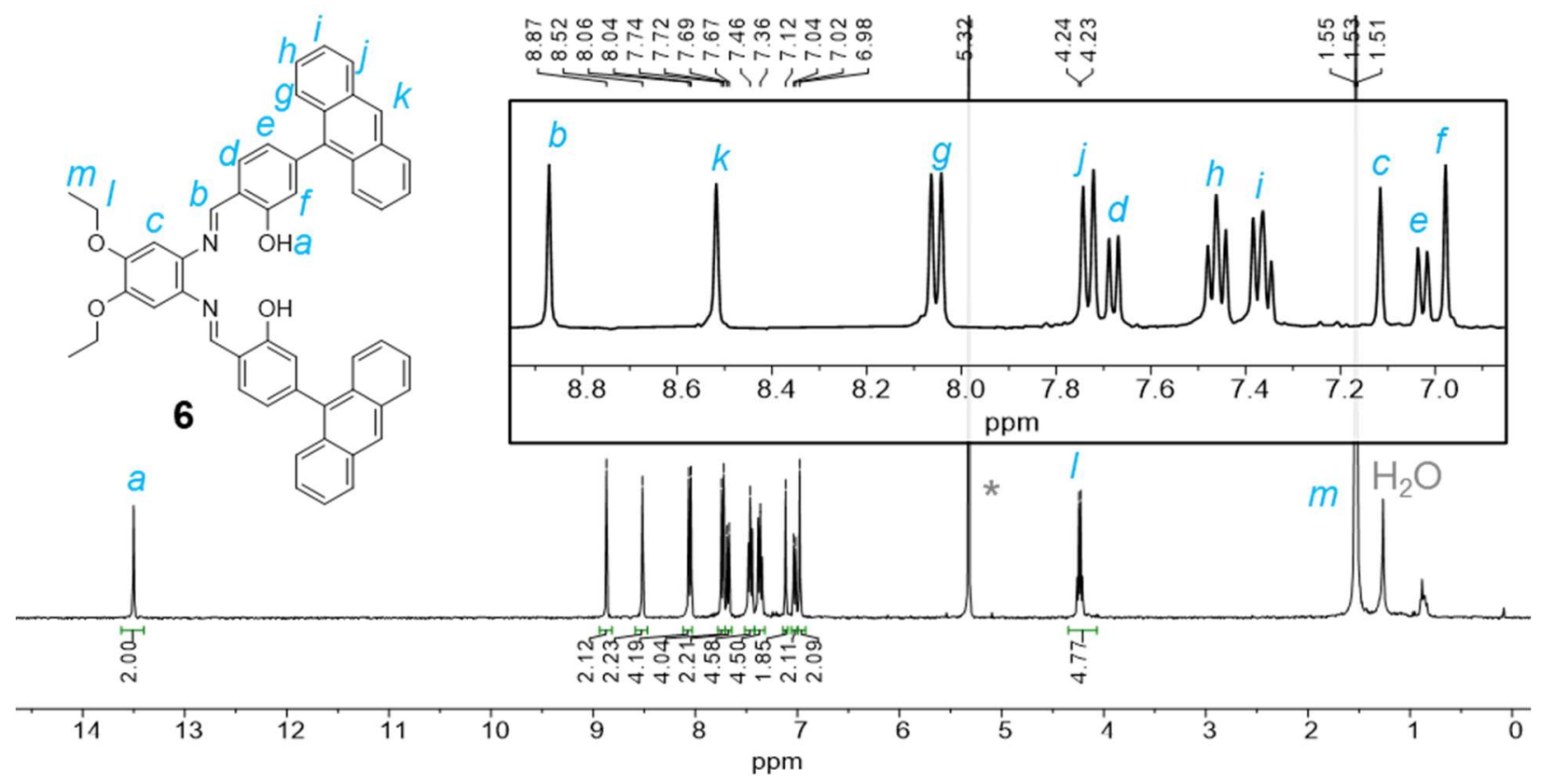

Figure S21. ${ }^{1} \mathrm{H}$ NMR spectrum $\left(400 \mathrm{MHz}, 25^{\circ} \mathrm{C}\right.$, DCM- $\left.d_{2}\right)$ of compound 6.

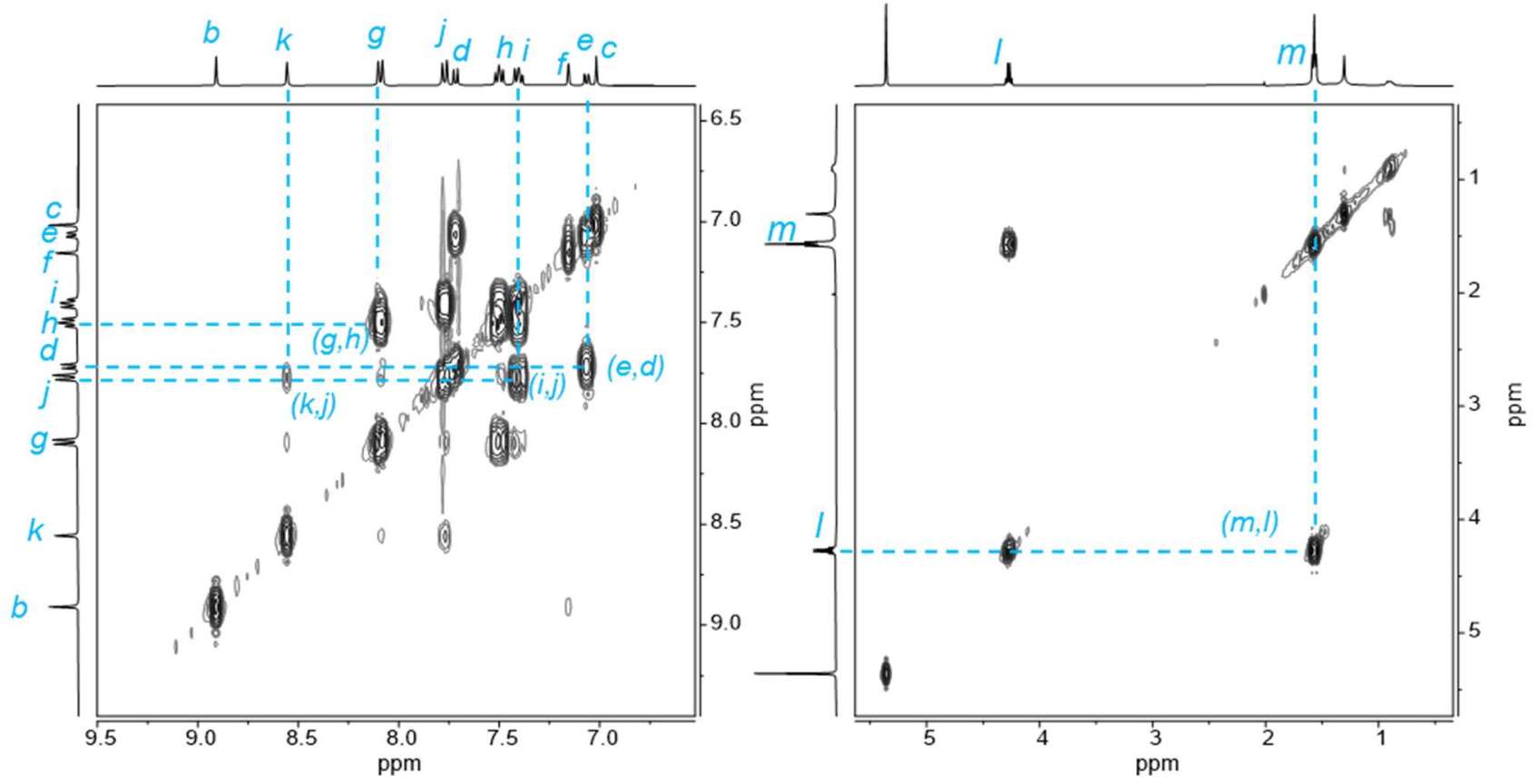

Figure S22. Partial ${ }^{1} \mathrm{H}-{ }^{1} \mathrm{H}-\mathrm{COSY}$ spectrum $\left(400 \mathrm{MHz}, 25^{\circ} \mathrm{C}, \mathrm{DCM}-d_{2}\right)$ of compound 6 highlighting important cross-peaks. 

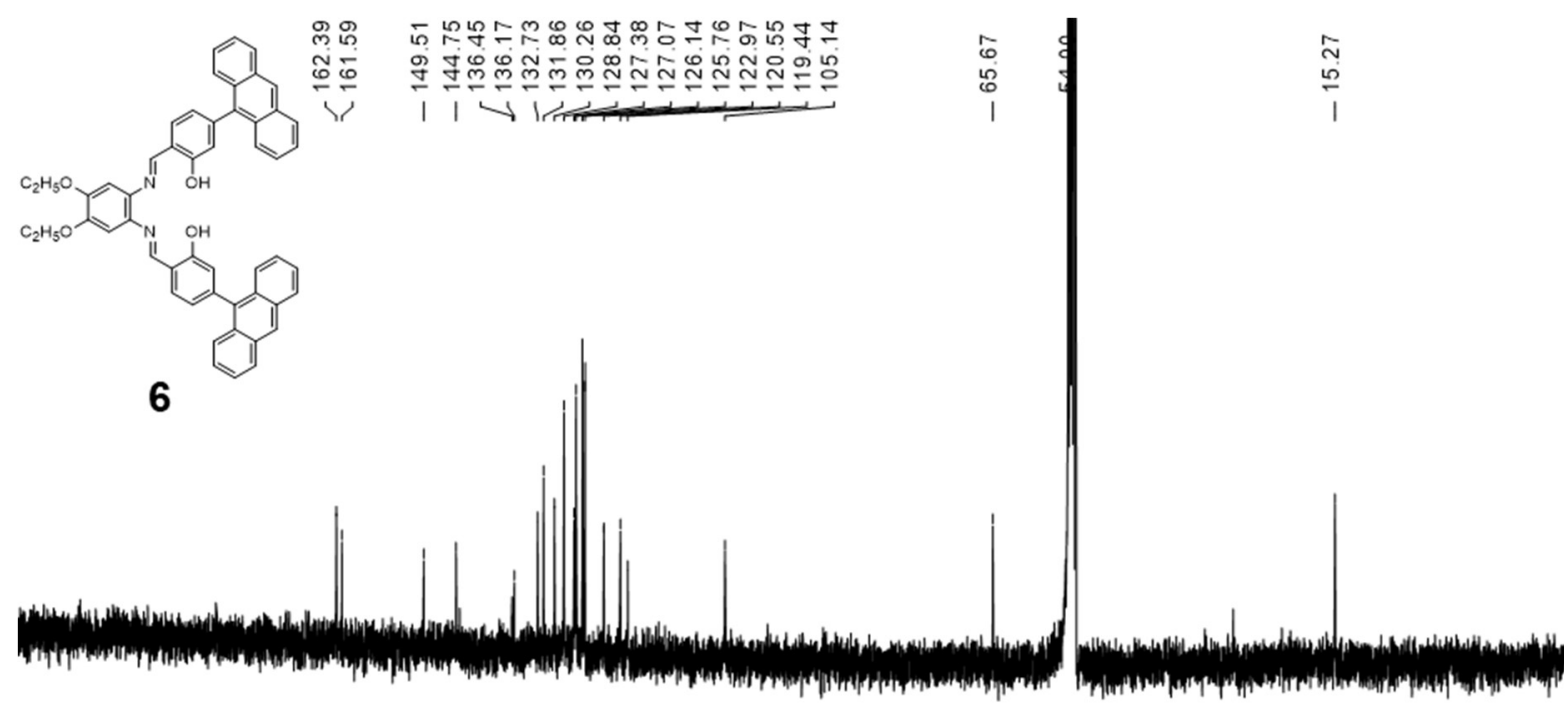

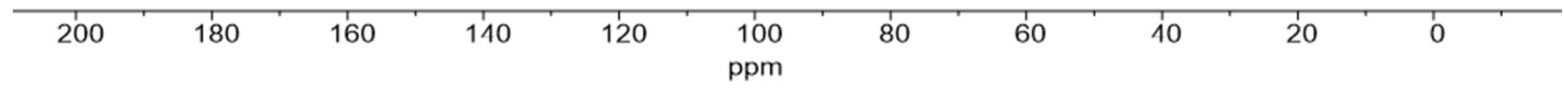

Figure $S 23 .{ }^{13} \mathrm{C}\left\{{ }^{1} \mathrm{H}\right\}$ NMR spectrum $\left(101 \mathrm{MHz}, 25^{\circ} \mathrm{C}, \mathrm{DCM}-\mathrm{d}_{2}\right)$ of compound 6.

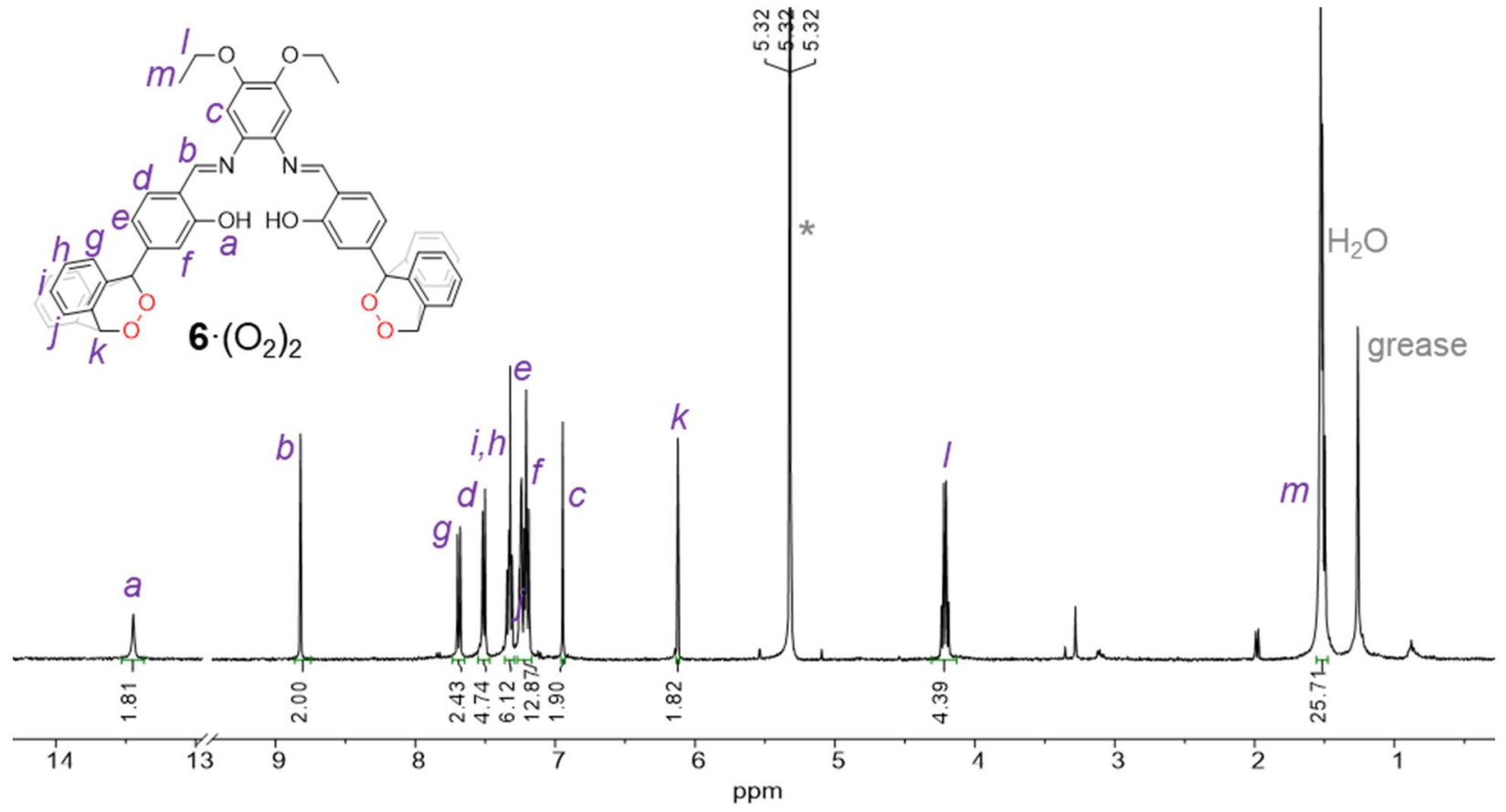

Figure S24. ${ }^{1} \mathrm{H}$ NMR spectrum $\left(400 \mathrm{MHz}, 25^{\circ} \mathrm{C}\right.$, DCM- $\left.d_{2}\right)$ of compound $6 \cdot\left(\mathrm{O}_{2}\right)_{2}$. Note the partial decomposition due to 6 and $\mathbf{6} \cdot\left(\mathrm{O}_{2}\right)_{2}$ being unstable under $h v$. 


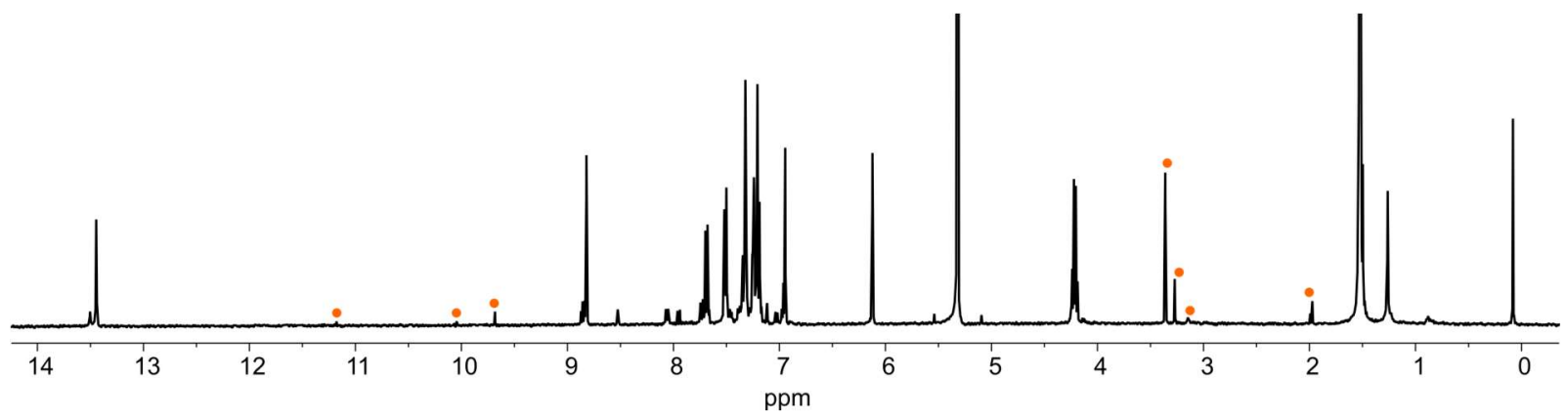

Figure S25. ${ }^{1} \mathrm{H}$ NMR spectra $\left(400 \mathrm{MHz}, 25^{\circ} \mathrm{C}, \mathrm{DCM}-d_{2}\right)$ for the conversion of 6 into $6 \cdot\left(\mathrm{O}_{2}\right)_{2}$. Orange circles highlight the partial decomposition seen after ca. 30 mins.

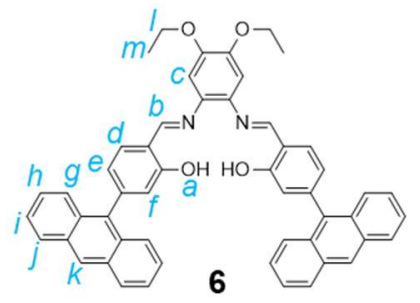

A)

B)
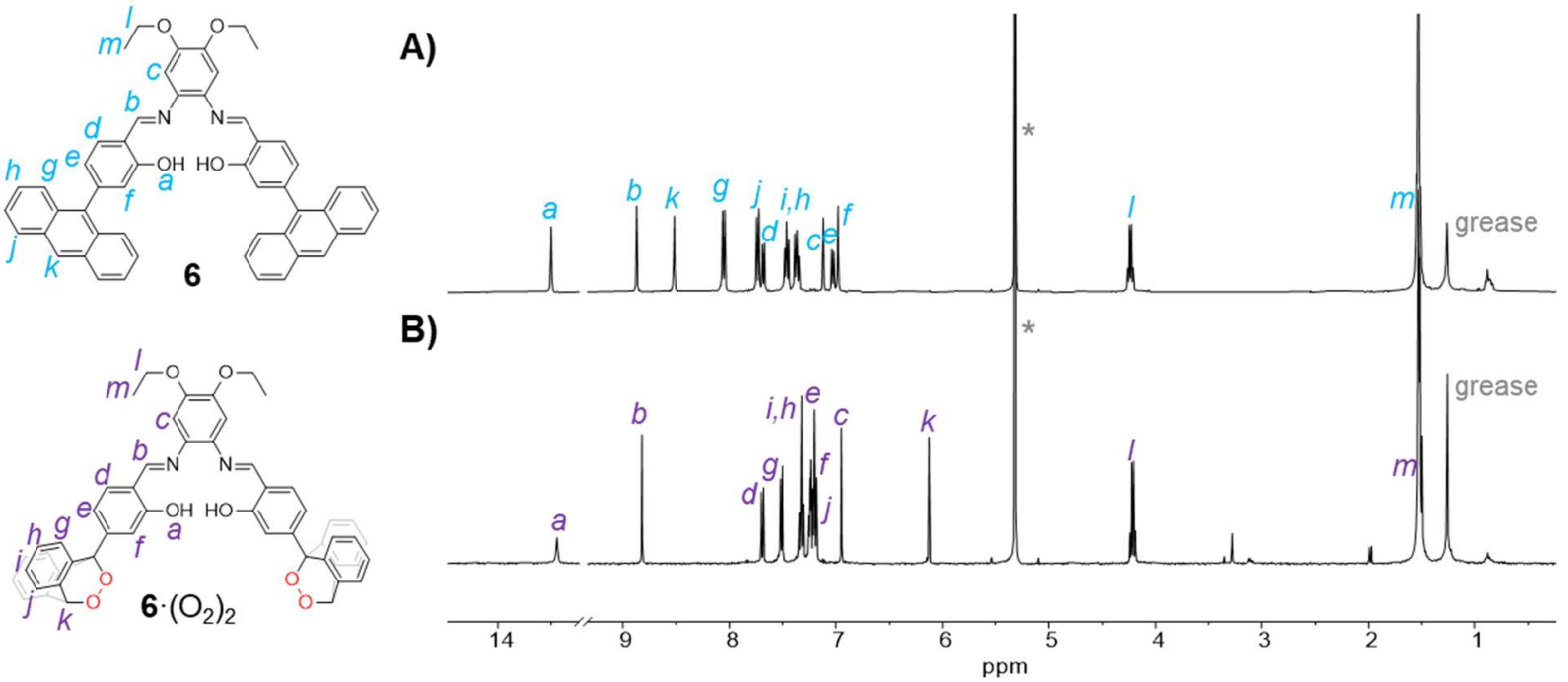

Figure S26. Stacked ${ }^{1} \mathrm{H}$ NMR spectra $\left(400 \mathrm{MHz}, 25^{\circ} \mathrm{C}, \mathrm{DCM}-\mathrm{d}_{2}\right)$ for A) 6 , and $\left.\mathrm{B}\right) \mathbf{6} \cdot\left(\mathrm{O}_{2}\right)_{2}$.

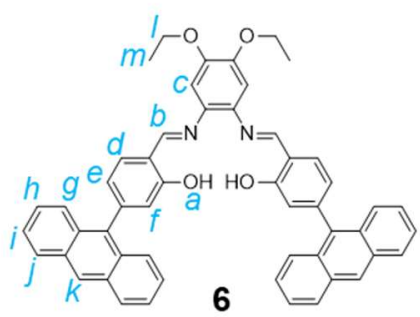

A)

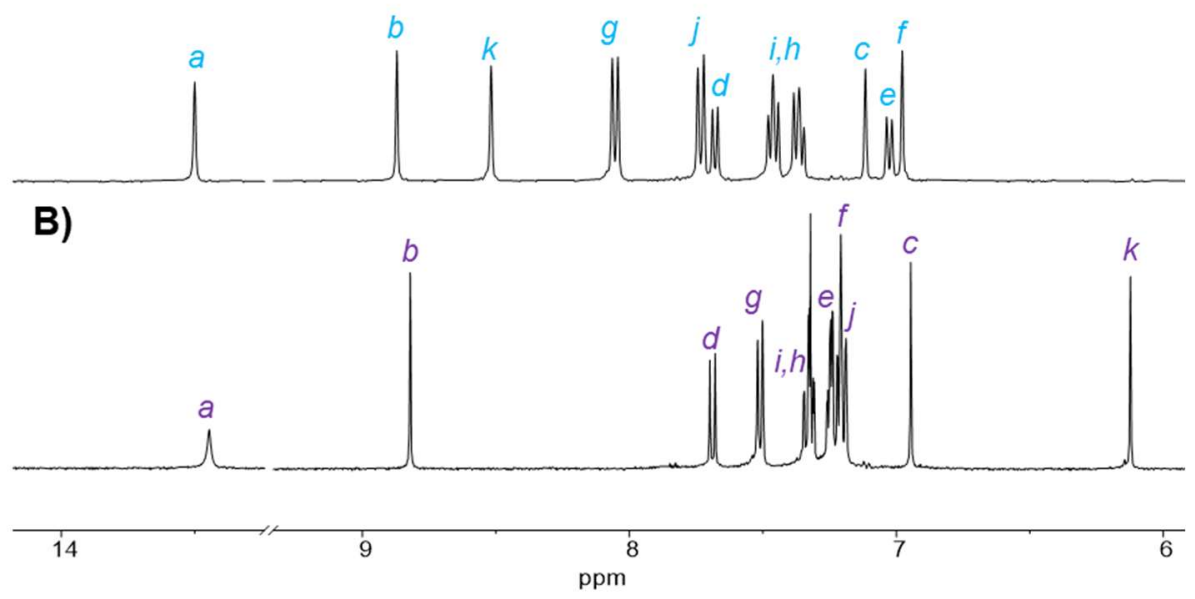

Figure S27. Stacked ${ }^{1} \mathrm{H}$ NMR spectra $\left(400 \mathrm{MHz}, 25^{\circ} \mathrm{C}, \mathrm{DCM}-\mathrm{d}_{2}\right)$ for A) 6 , and B) $6 \cdot\left(\mathrm{O}_{2}\right) 2$. 
Note the large upfield shifting of $\mathrm{H}_{k}$ following endo peroxide formation. Through ${ }^{13} \mathrm{C}\left\{{ }^{1} \mathrm{H}\right\} N \mathrm{NMR}$ we also see the appearance of resonances at 80.05 and 83.35 , which correspond to the carbons attached to the endoperoxide group.

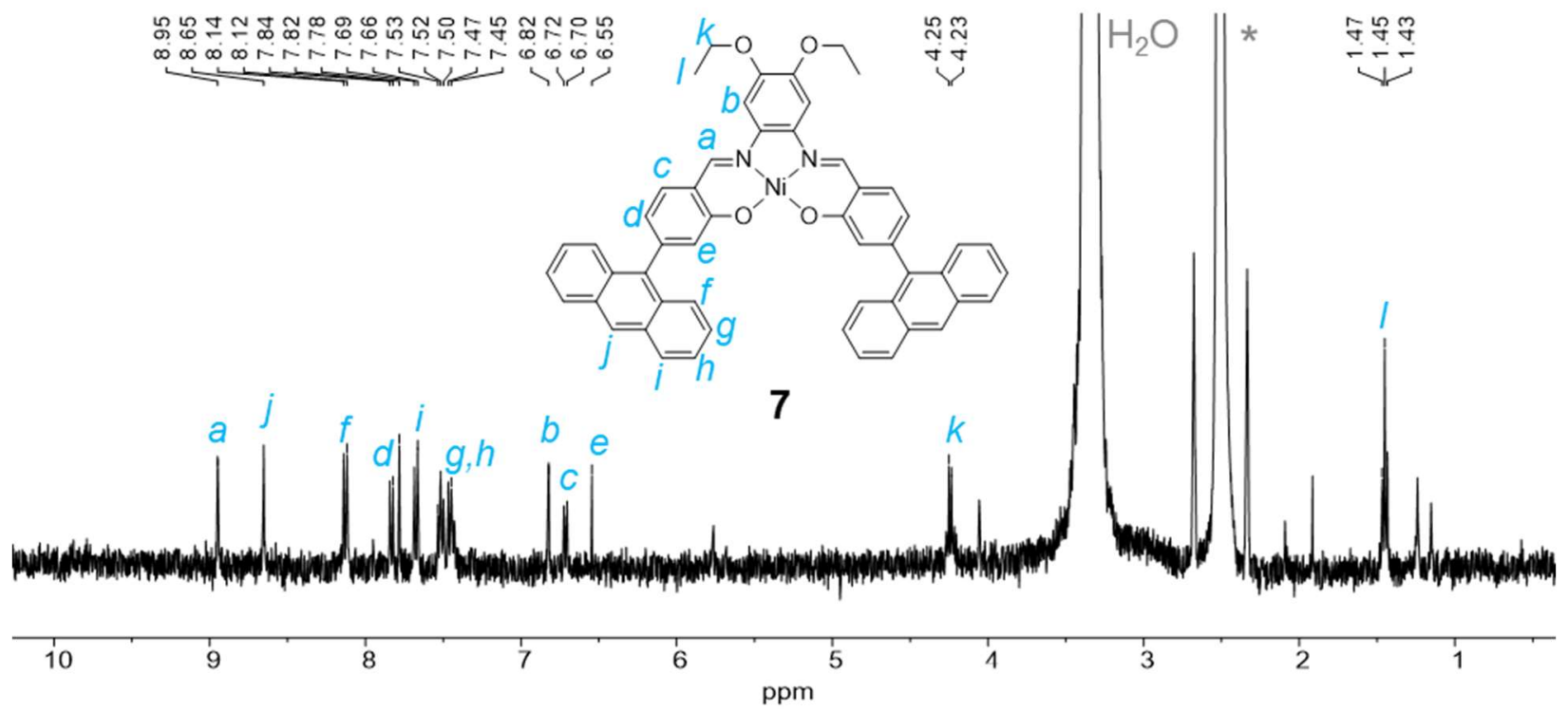

Figure S28. ${ }^{1} \mathrm{H}$ NMR spectrum $\left(400 \mathrm{MHz}, 25^{\circ} \mathrm{C}\right.$, DMSO-d $)$ of compound 7.
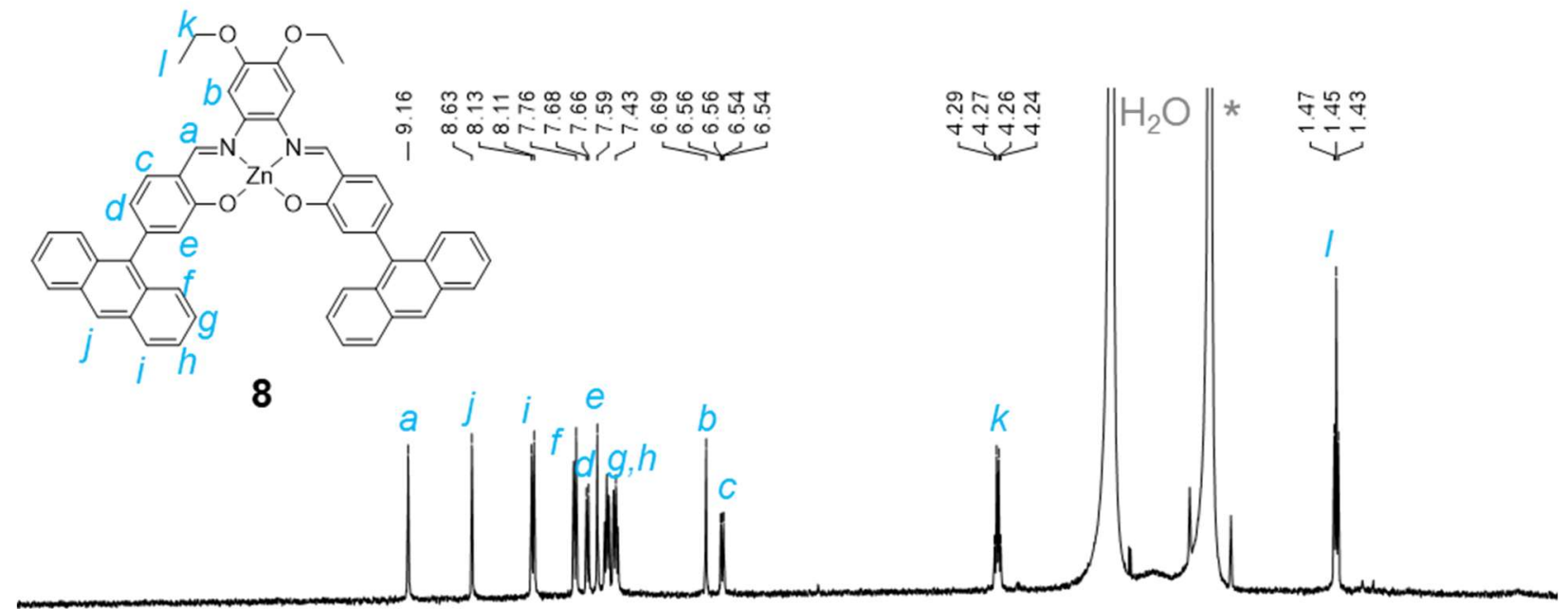

12
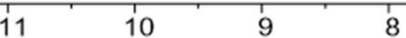

6
ppm

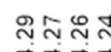

$\sqrt{i+4.4}$

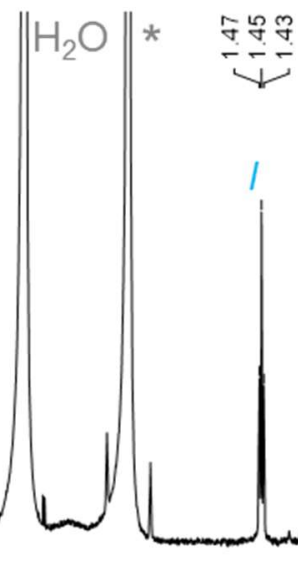

Figure S29. ${ }^{1} \mathrm{H}$ NMR spectrum $\left(400 \mathrm{MHz}, 25^{\circ} \mathrm{C}\right.$, DMSO- $\left.d_{6}\right)$ of compound 8. 


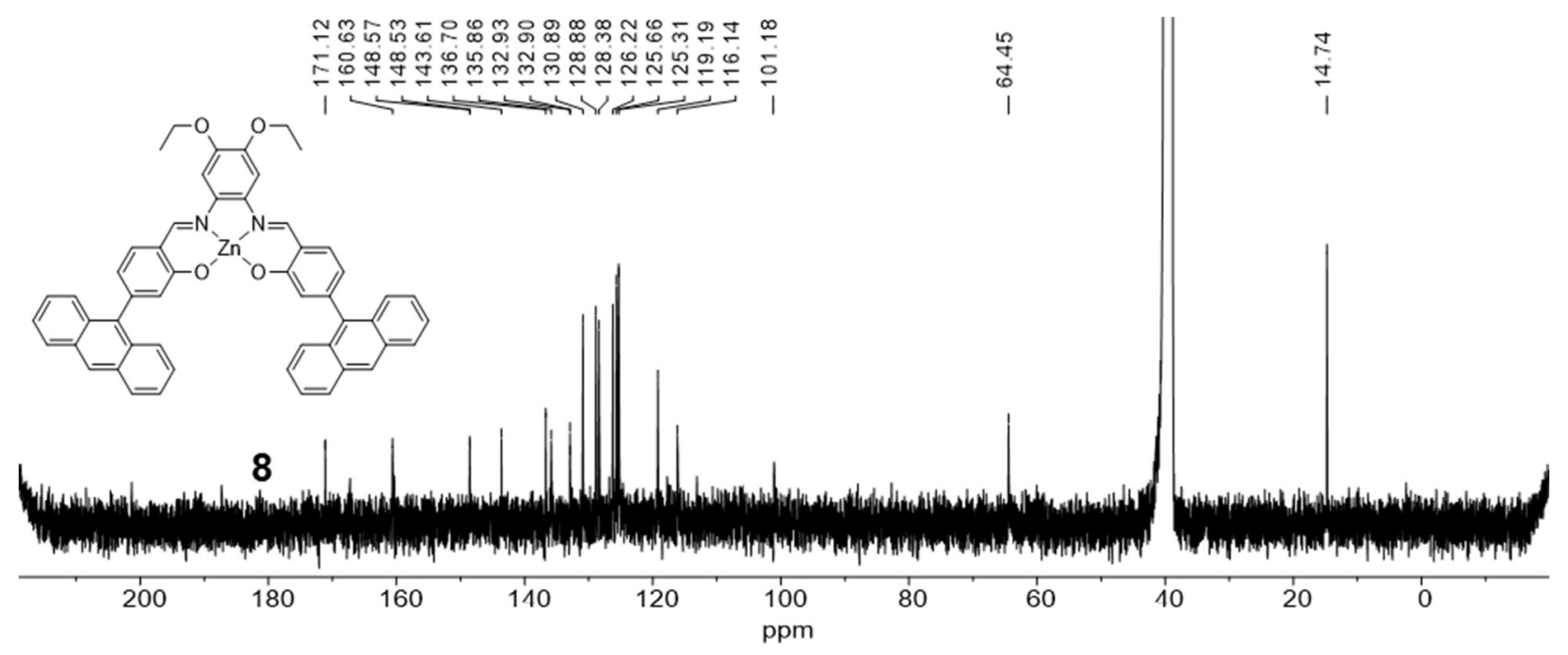

Figure $\mathrm{S} 30 .{ }^{13} \mathrm{C}\left\{{ }^{1} \mathrm{H}\right\} \mathrm{NMR}$ spectrum $\left(101 \mathrm{MHz}, 25^{\circ} \mathrm{C}\right.$, DMSO-d $)$ of compound 8.

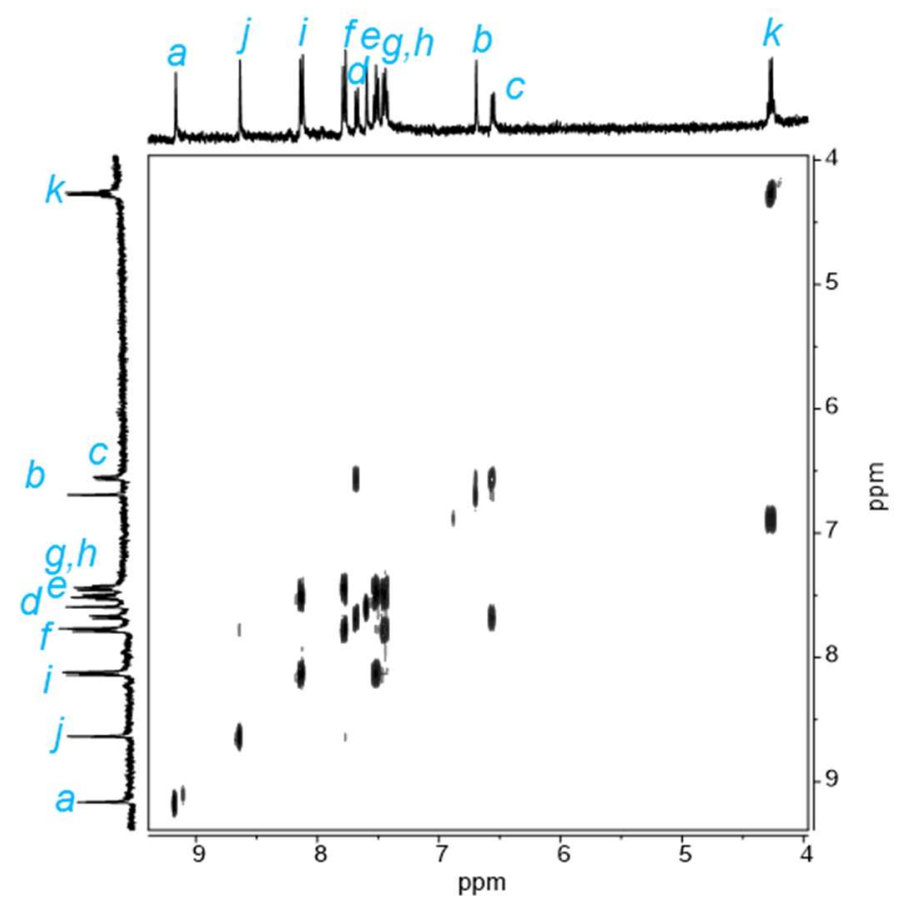

Figure S31. Partial ${ }^{1} \mathrm{H}-{ }^{1} \mathrm{H}$ COSY NMR spectrum (400 MHz, $25^{\circ} \mathrm{C}$, DMSO- $\left.d_{6}\right)$ of compound 8. 


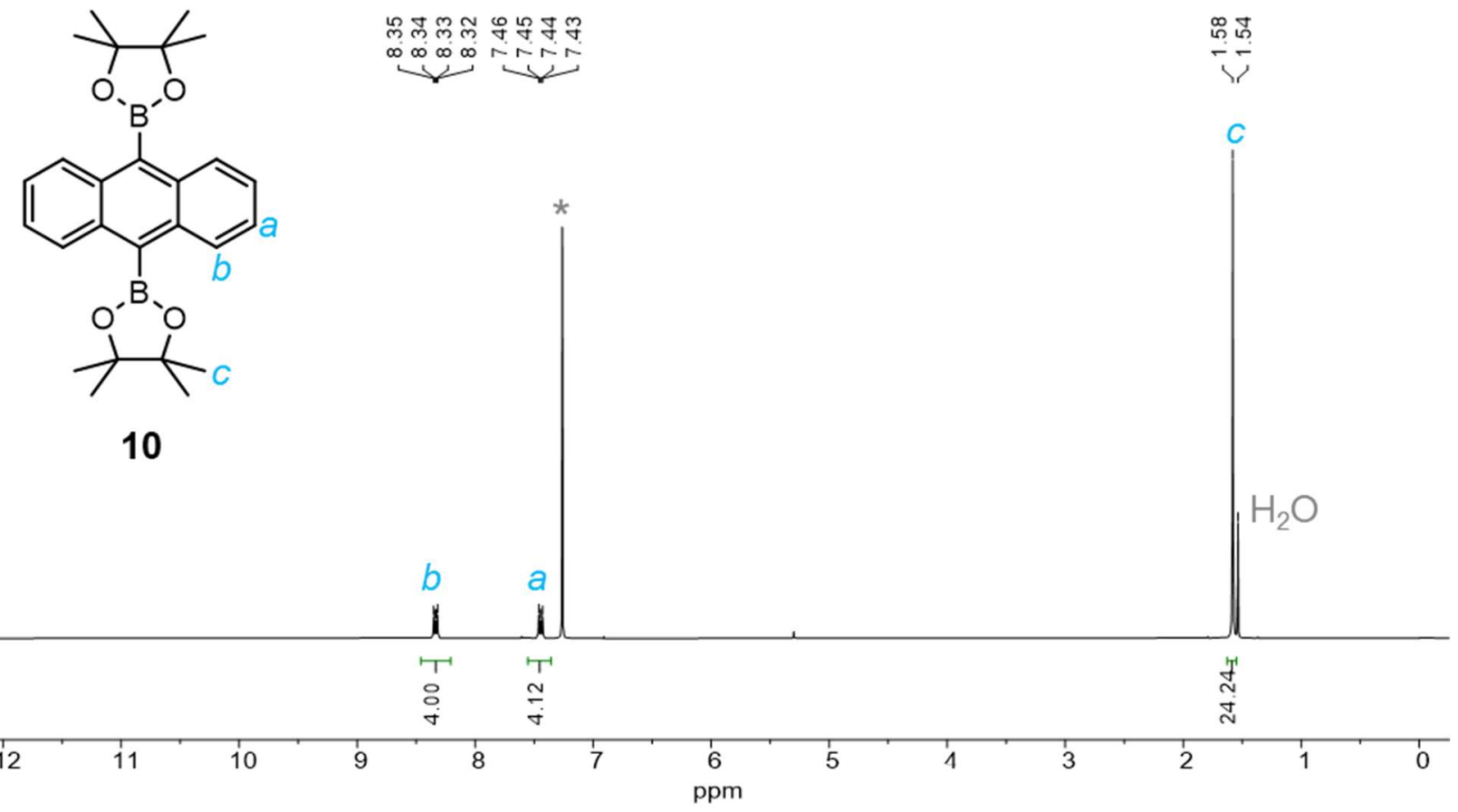

Figure S32. ${ }^{1} \mathrm{H}$ NMR spectrum $\left(400 \mathrm{MHz}, 25^{\circ} \mathrm{C}, \mathrm{CDCl}_{3}\right)$ of compound 10.

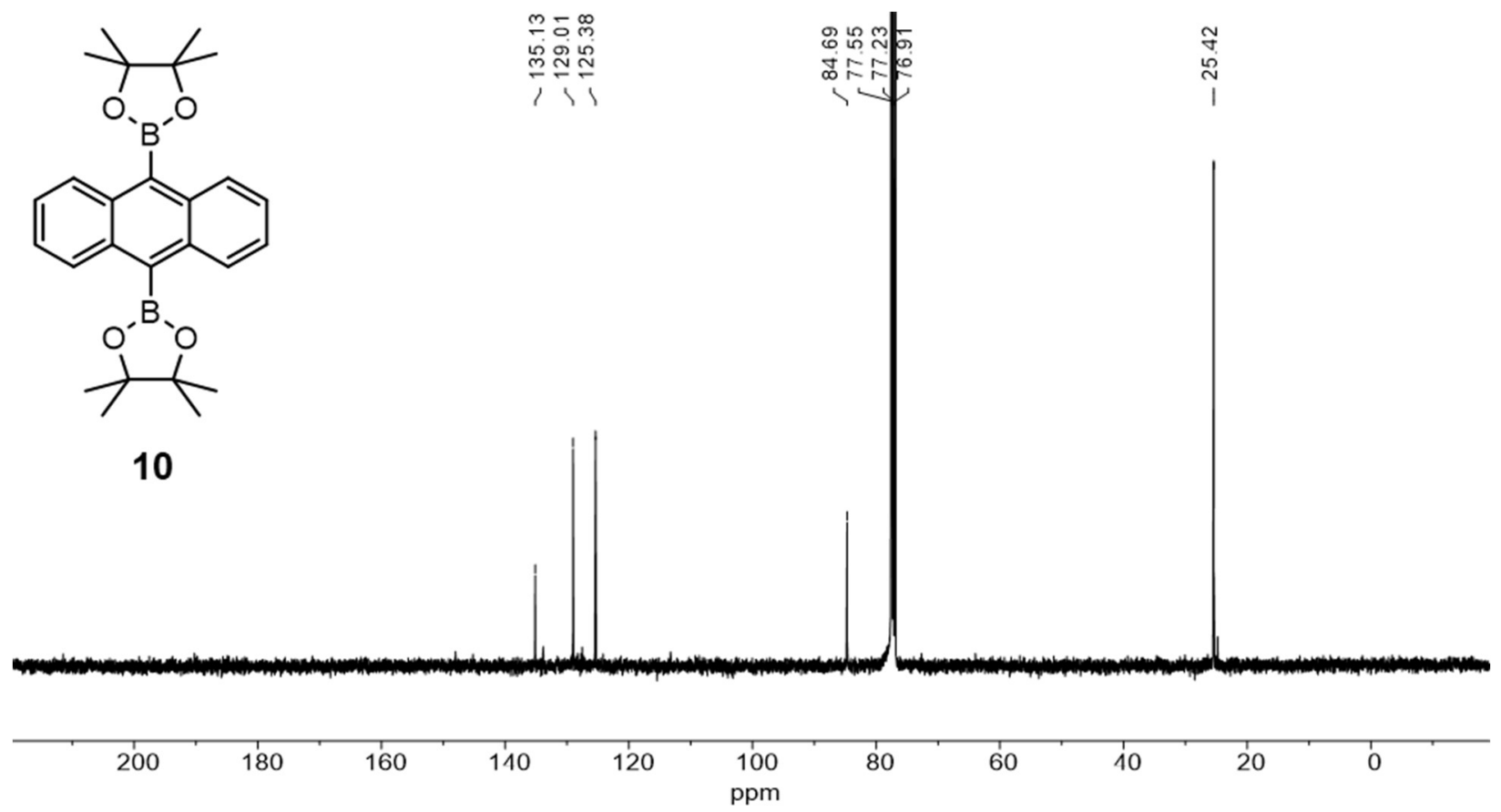

Figure $\mathrm{S} 33 .{ }^{13} \mathrm{C}\left\{{ }^{1} \mathrm{H}\right\}$ NMR spectrum $\left(101 \mathrm{MHz}, 25^{\circ} \mathrm{C}, \mathrm{CDCl}_{3}\right)$ of compound 10. 


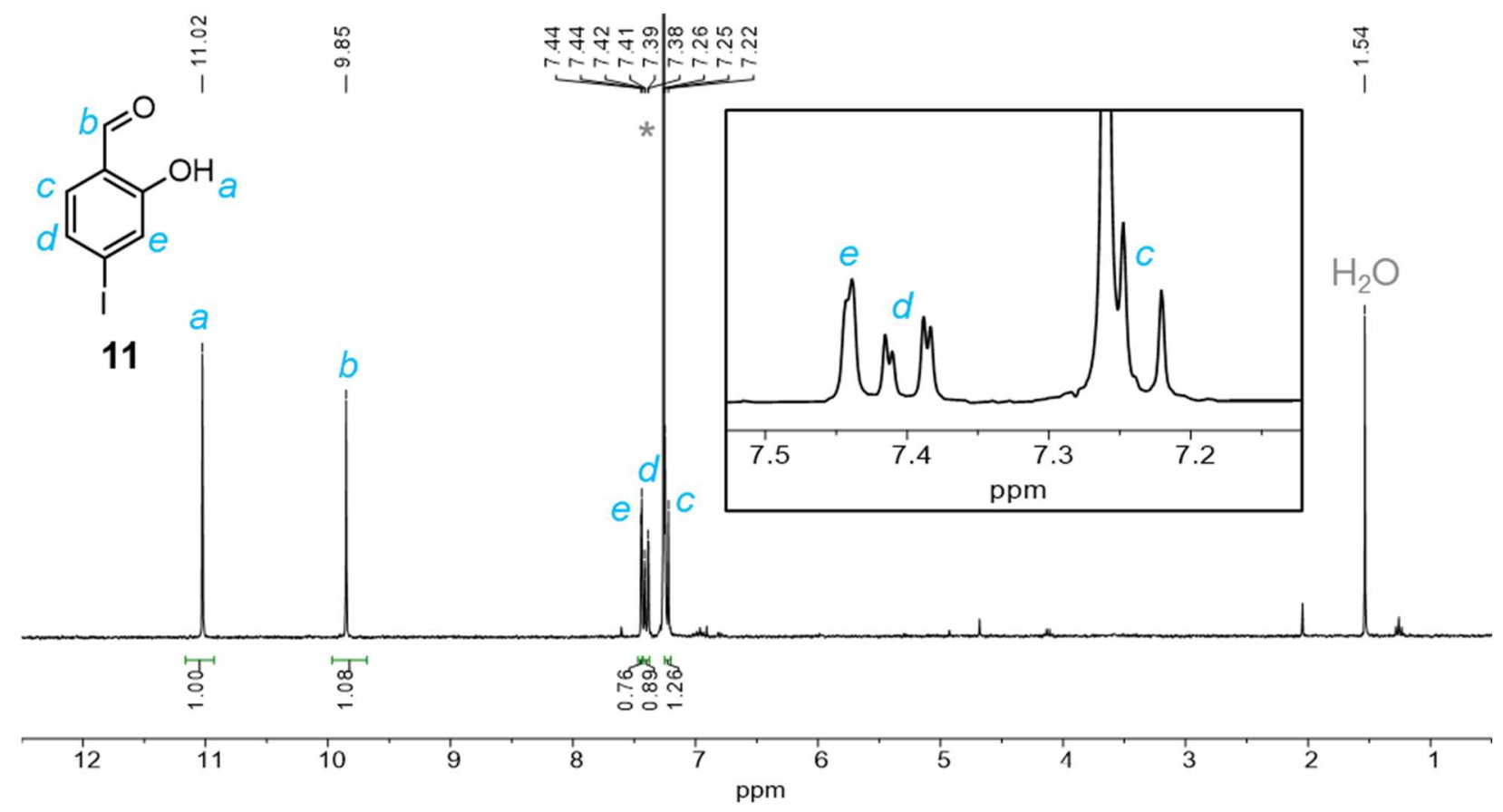

Figure S34. ${ }^{1} \mathrm{H}$ NMR spectrum $\left(400 \mathrm{MHz}, 25^{\circ} \mathrm{C}, \mathrm{CDCl}_{3}\right)$ of compound 11.

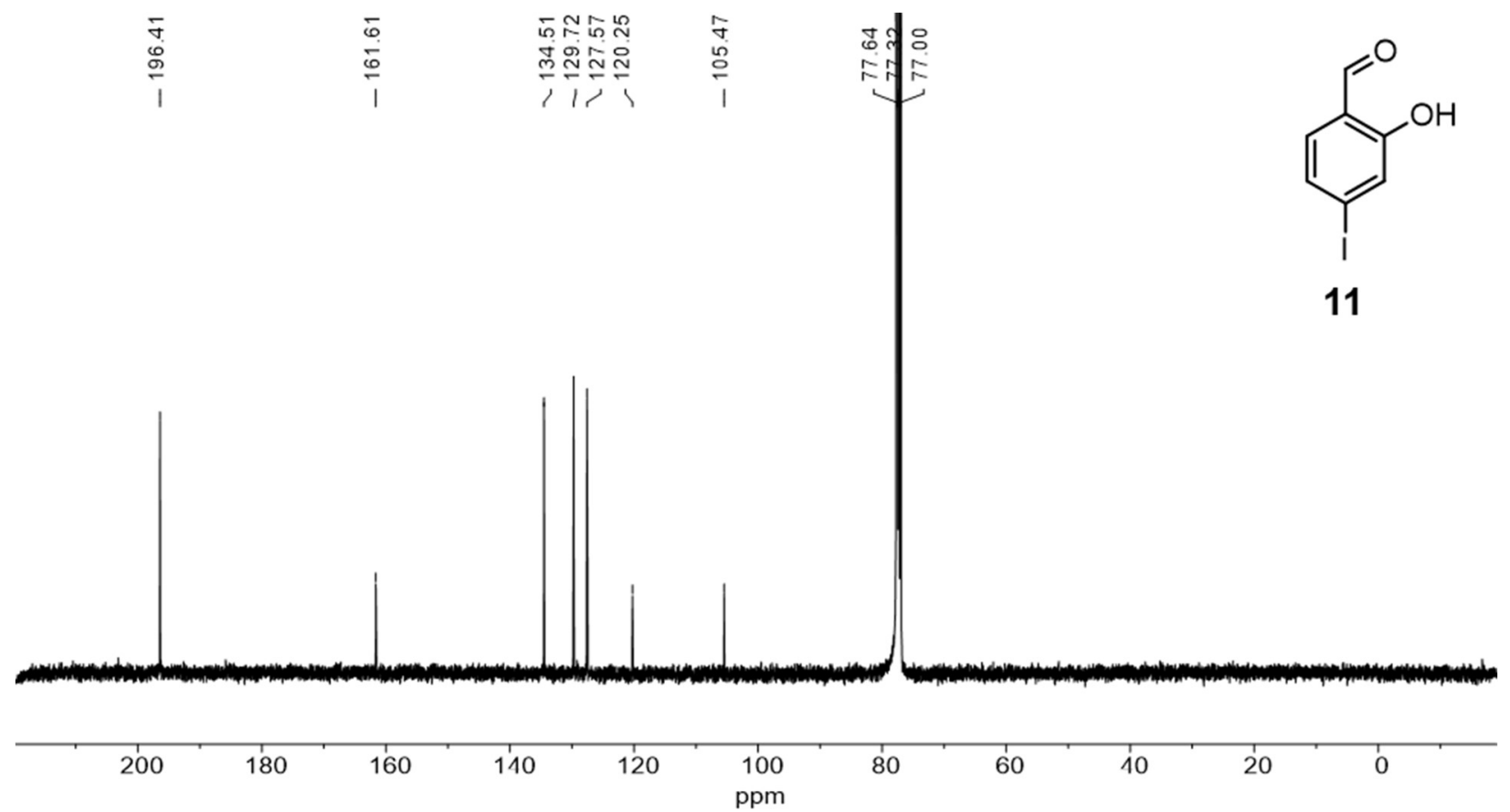

Figure S35. ${ }^{13} \mathrm{C}\left\{{ }^{1} \mathrm{H}\right\}$ NMR spectrum $\left(101 \mathrm{MHz}, 25^{\circ} \mathrm{C}, \mathrm{CDCl}_{3}\right)$ of compound 11. 


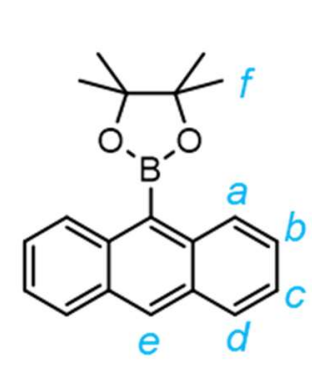

ขै ๆ ๆ ๆ

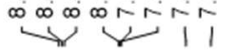

13

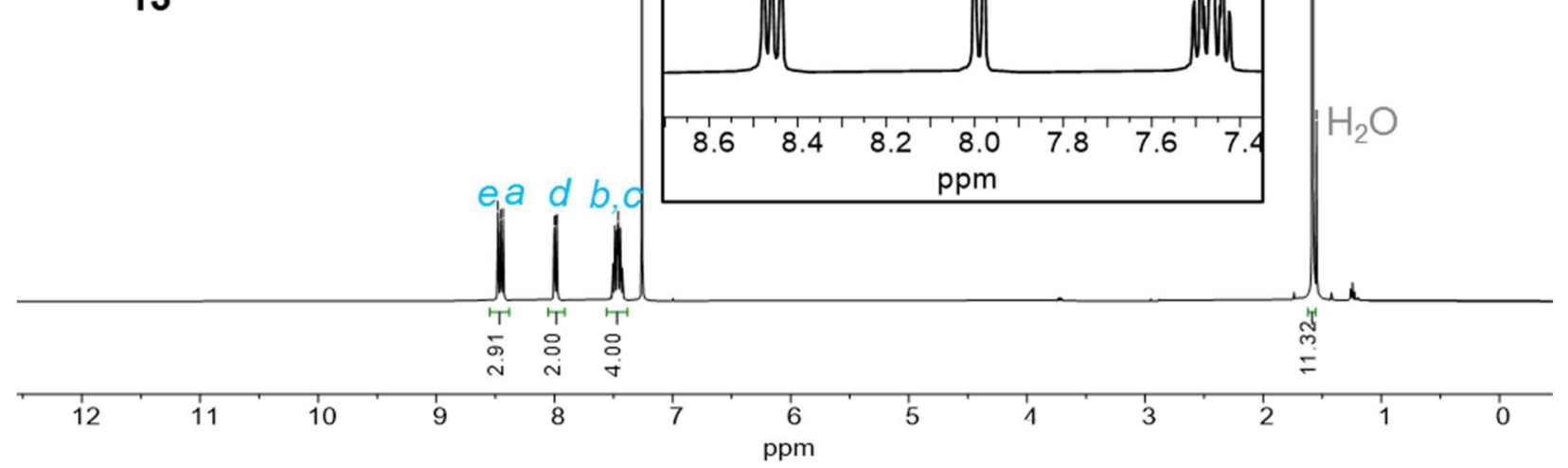

Figure S36. ${ }^{1} \mathrm{H}$ NMR spectrum $\left(400 \mathrm{MHz}, 25^{\circ} \mathrm{C}, \mathrm{CDCl}_{3}\right)$ of compound 13.
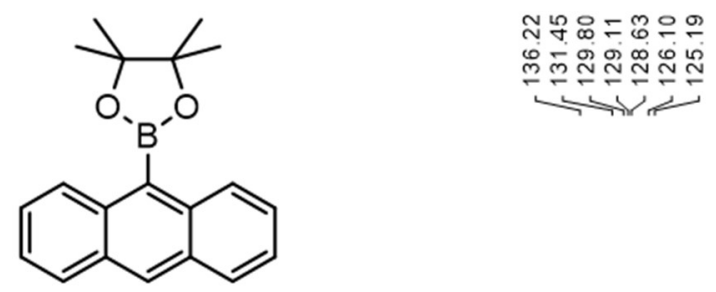

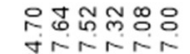

mivinis

W

กับ

13
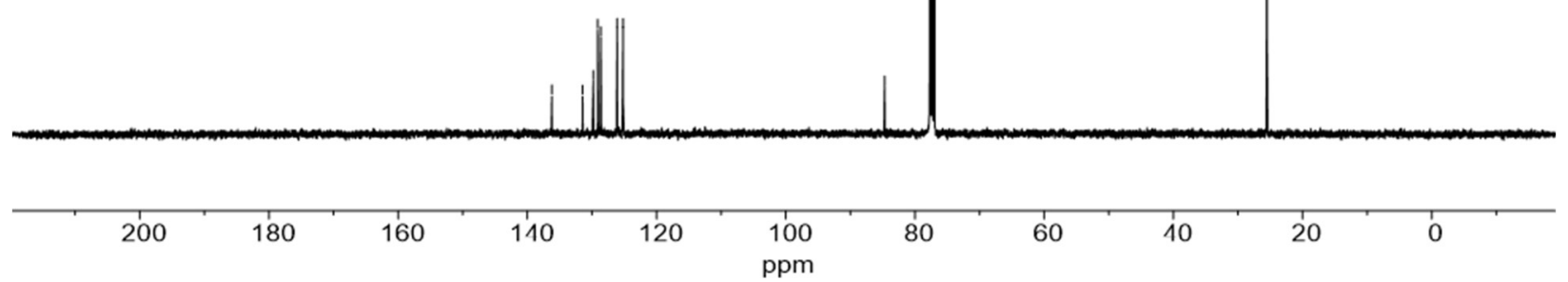

Figure $\mathrm{S} 37 .{ }^{13} \mathrm{C}\left\{{ }^{1} \mathrm{H}\right\}$ NMR spectrum $\left(101 \mathrm{MHz}, 25^{\circ} \mathrm{C}, \mathrm{CDCl}_{3}\right)$ of compound 13. 


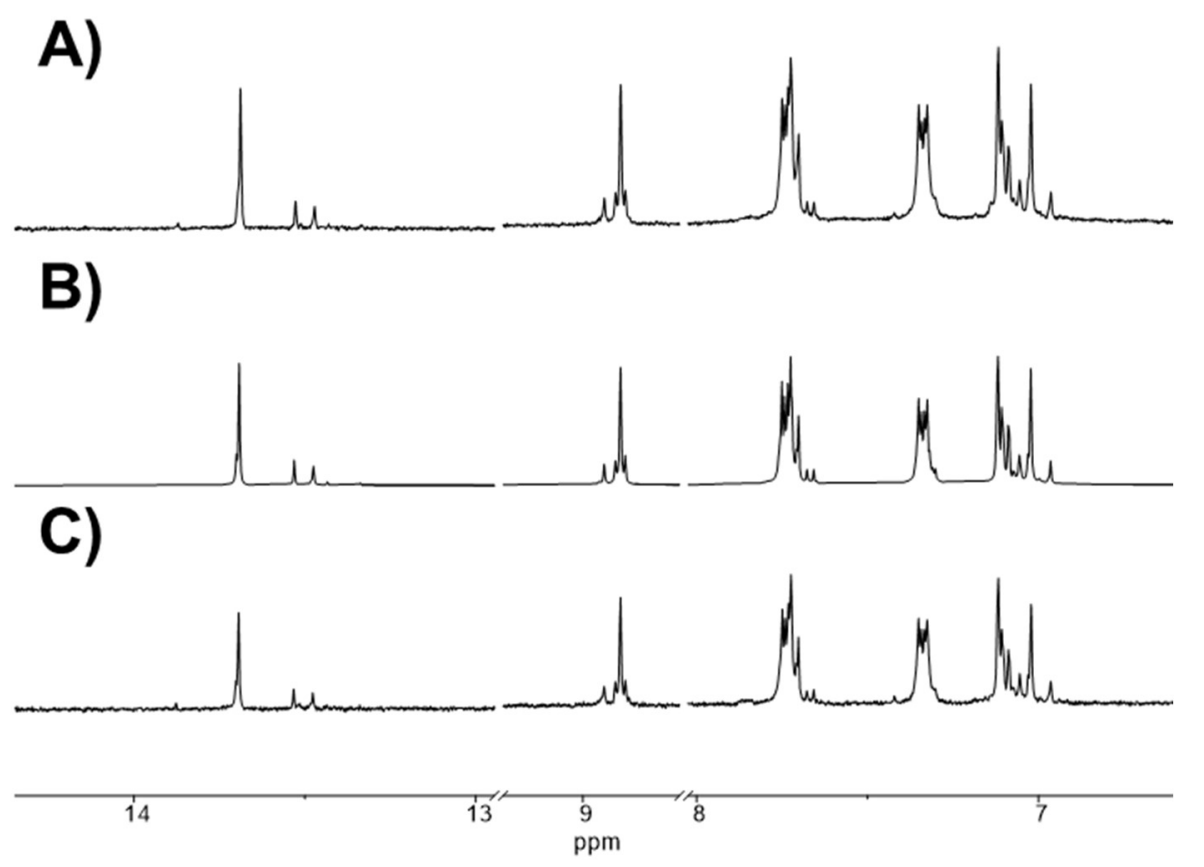

Figure S38. Partial stacked ${ }^{1} \mathrm{H}$ NMR spectra $\left(400 \mathrm{MHz}, 25^{\circ} \mathrm{C}, \mathrm{DCM}-\mathrm{d}_{2}\right)$ for 1 prepared using degassed solvent A) freeze-pump-thaw and in the dark, B) in a glovebox, and C) with a Schlenk line.

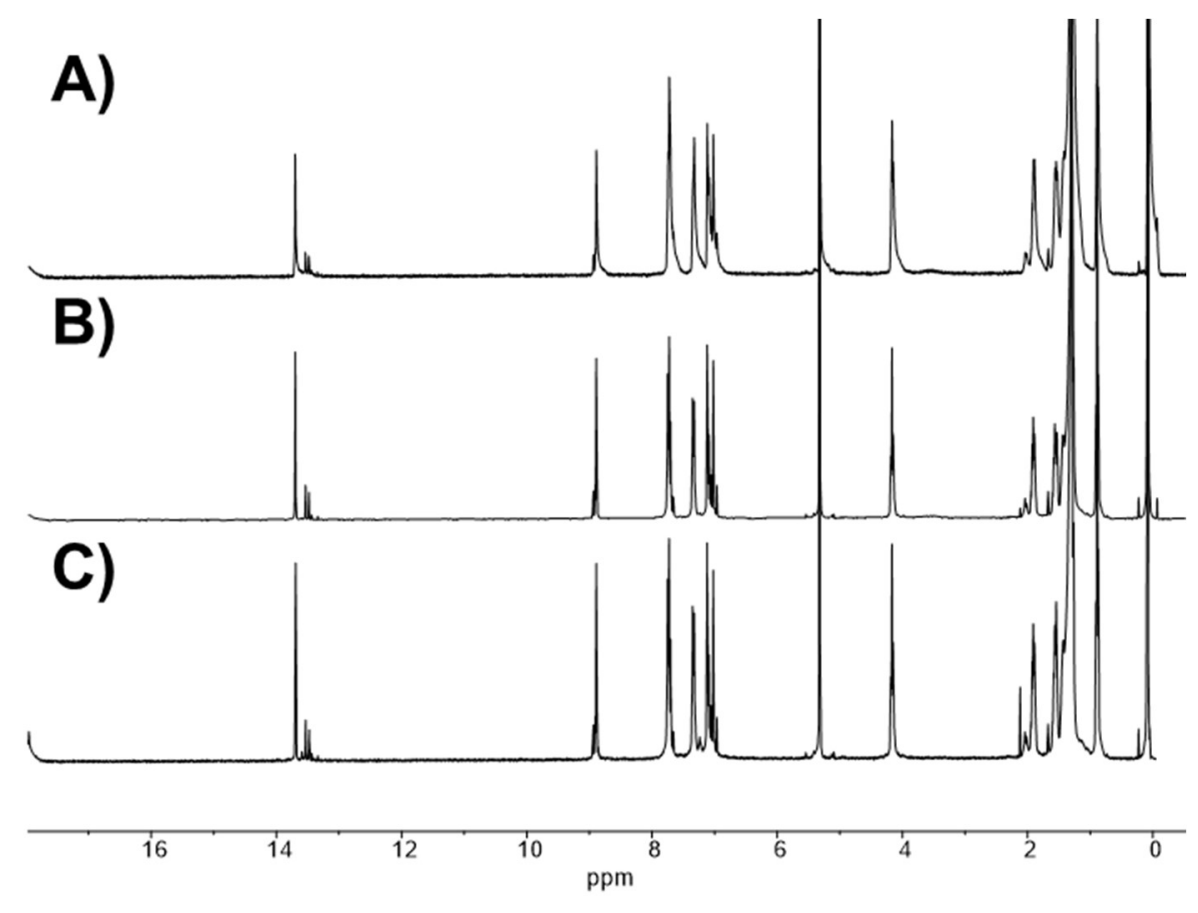

Figure S39. Partial stacked ${ }^{1} \mathrm{H}$ NMR spectra $\left(400 \mathrm{MHz}, 25^{\circ} \mathrm{C}, \mathrm{DCM}-d_{2}\right)$ of 1 after A) 0 days, B) 5 days, and C) 30 days in solution. 


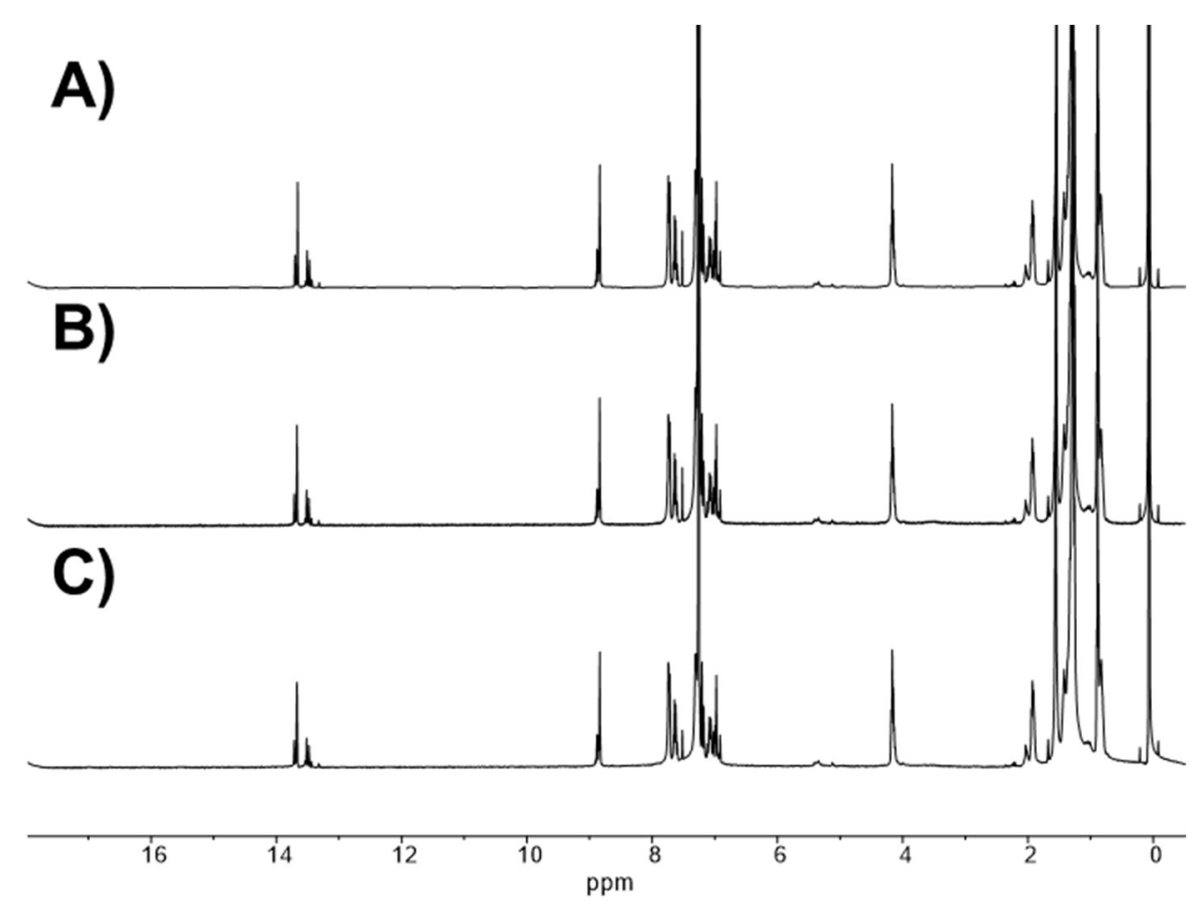

Figure S40. Partial stacked ${ }^{1} \mathrm{H}$ NMR spectra $\left(400 \mathrm{MHz}, 25^{\circ} \mathrm{C}, \mathrm{CDCl}_{3}\right)$ of 1 after heating at $70^{\circ} \mathrm{C}$ for $\left.\mathrm{A}\right) 0 \mathrm{~h}$, B) $56 \mathrm{~h}$, and C) $96 \mathrm{~h}$.

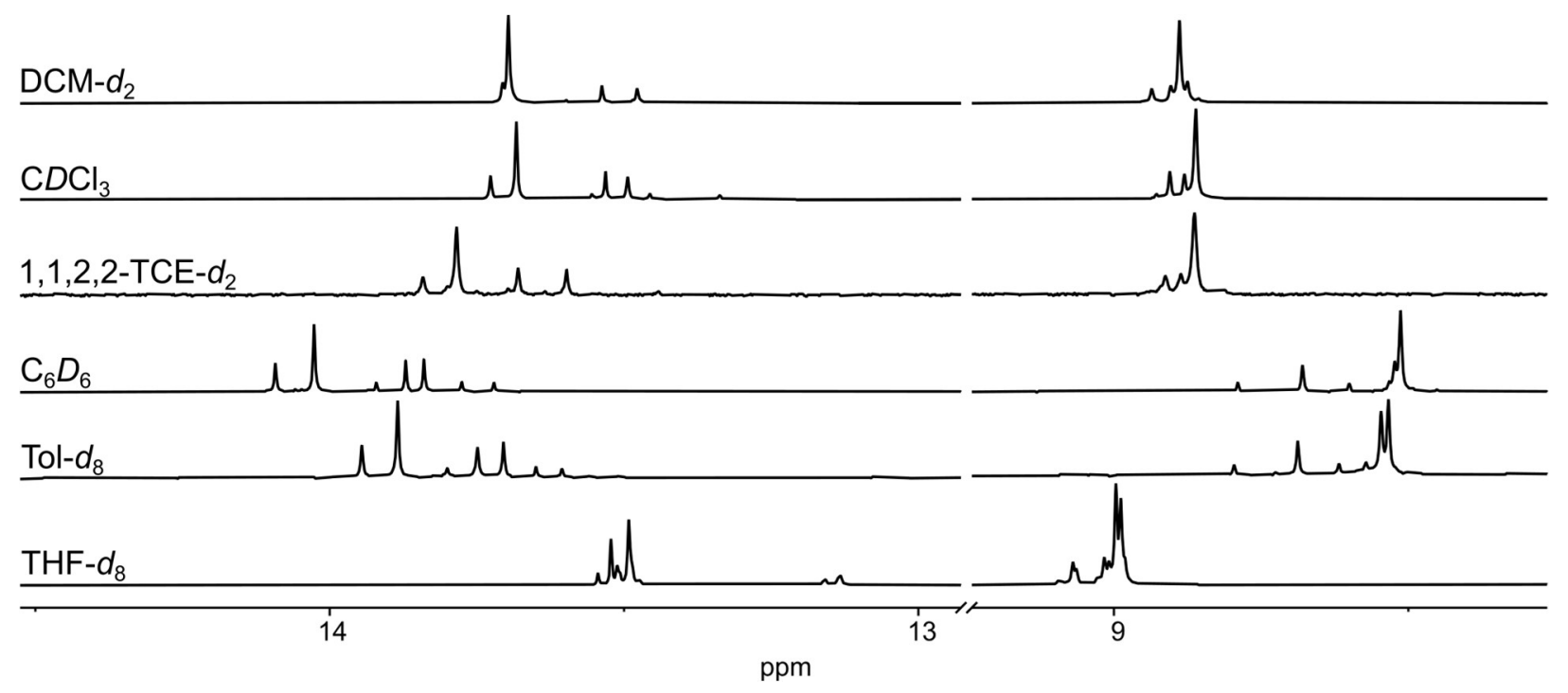

Figure S41. Partial stacked ${ }^{1} \mathrm{H}$ NMR spectra for $1\left(400 \mathrm{MHz}, 25^{\circ} \mathrm{C}\right)$ in various solvents. 


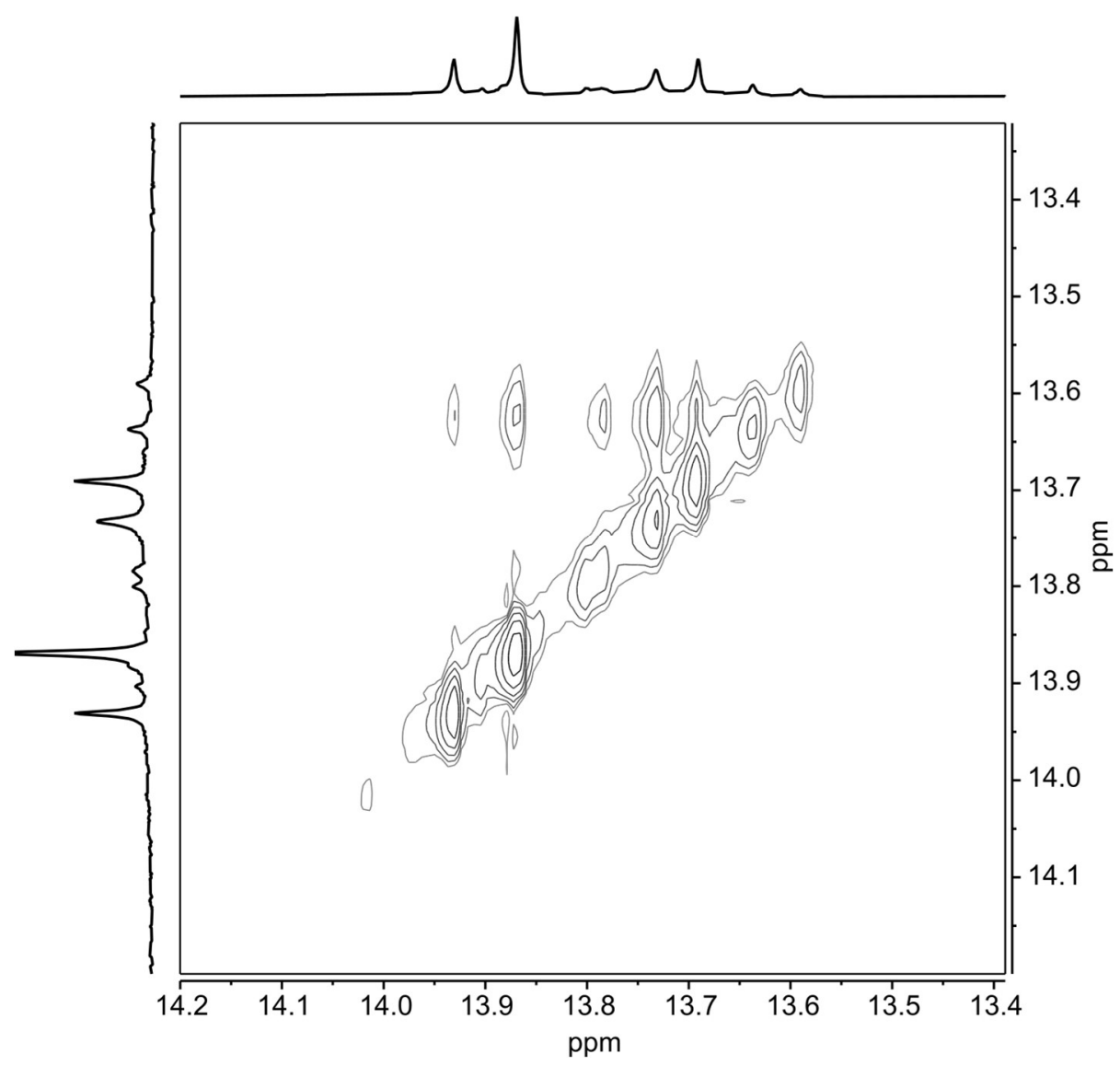

Figure S42. ${ }^{1} \mathrm{H}-{ }^{1} \mathrm{H}$ EXSY NMR (400 MHz, Tol- $\left.d_{8}\right)$ spectrum for 1 , highlighting phenolic resonances. 

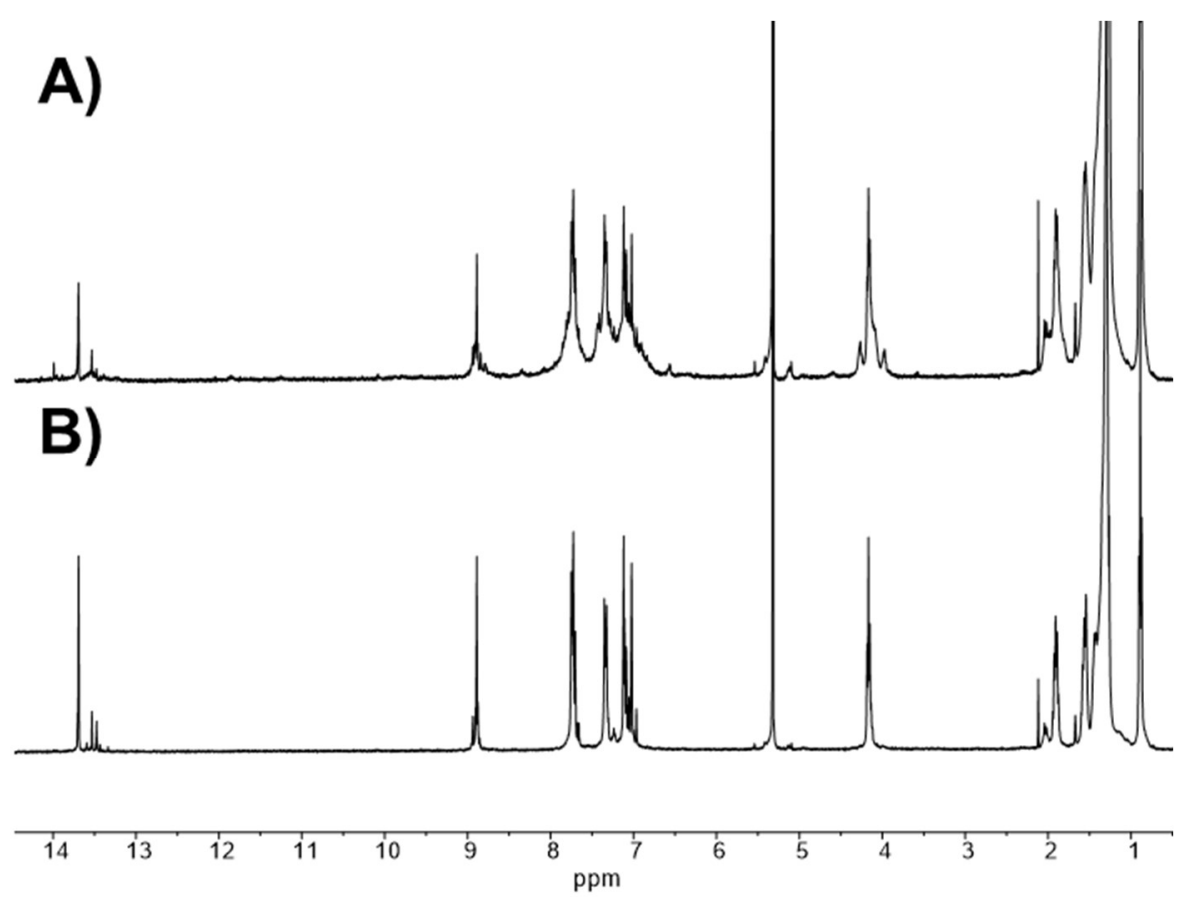

Figure S43. Partial stacked ${ }^{1} \mathrm{H}$ NMR spectra $\left(400 \mathrm{MHz}, 25^{\circ} \mathrm{C}, \mathrm{DCM}-d_{2}\right)$ of 1 after A) 4 hours of irradiation with $365 \mathrm{~nm}$ light, and B) before irradiation.

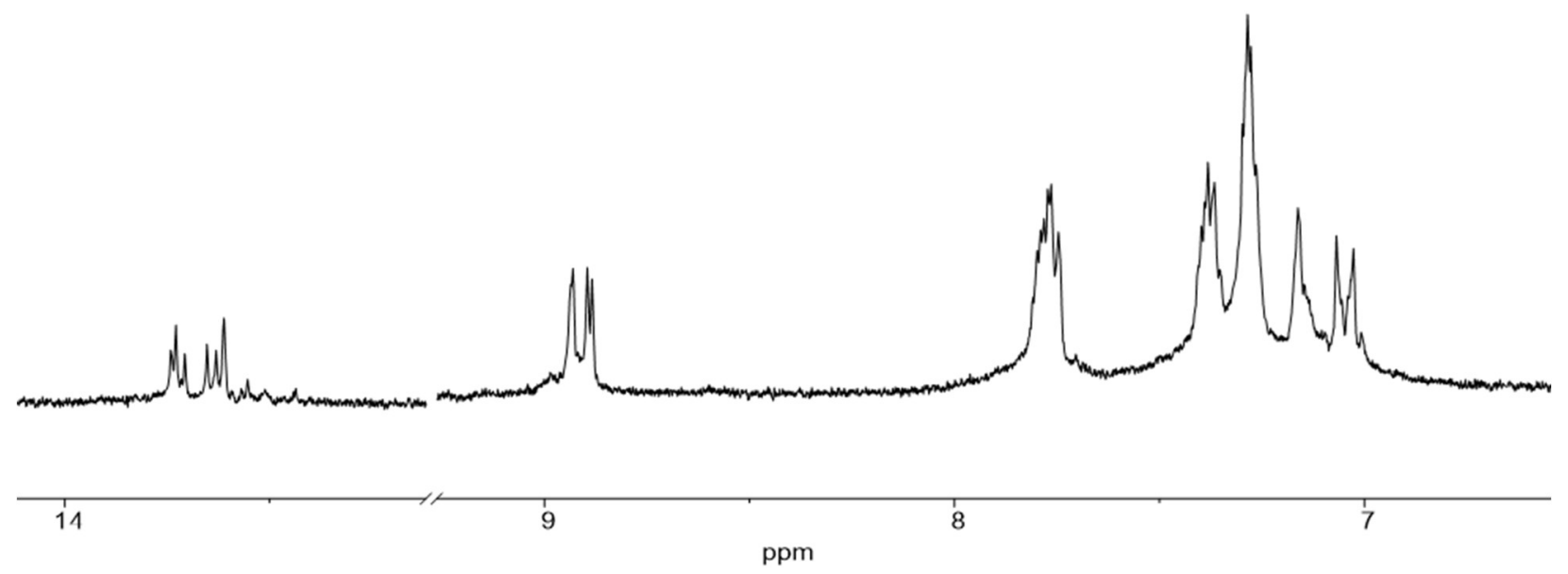

Figure S44. Partial ${ }^{1} \mathrm{H}$ NMR spectra $\left(400 \mathrm{MHz}, 25^{\circ} \mathrm{C}, \mathrm{DCM}-d_{2}\right)$ of 1 after 4 hours of irradiation with $600 \mathrm{~nm}$ light with no photosensitizer. 

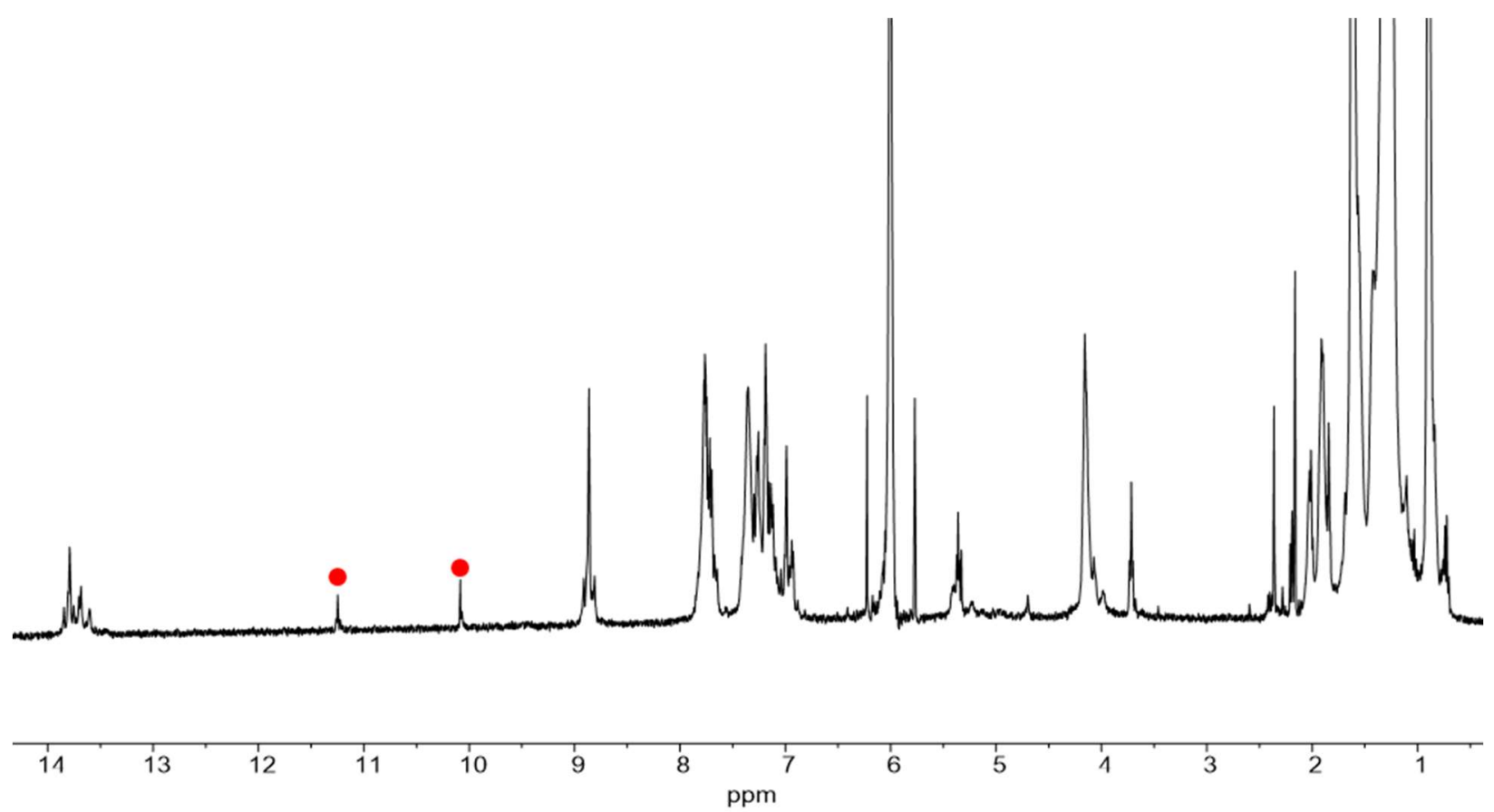

Figure S45. ${ }^{1} \mathrm{H}$ NMR spectra $\left(400 \mathrm{MHz}, 25^{\circ} \mathrm{C}, 1,1,2,2-\mathrm{TCE}-\mathrm{d}_{2}\right)$ of 1 after 4 hours of irradiation with $365 \mathrm{~nm}$ light.

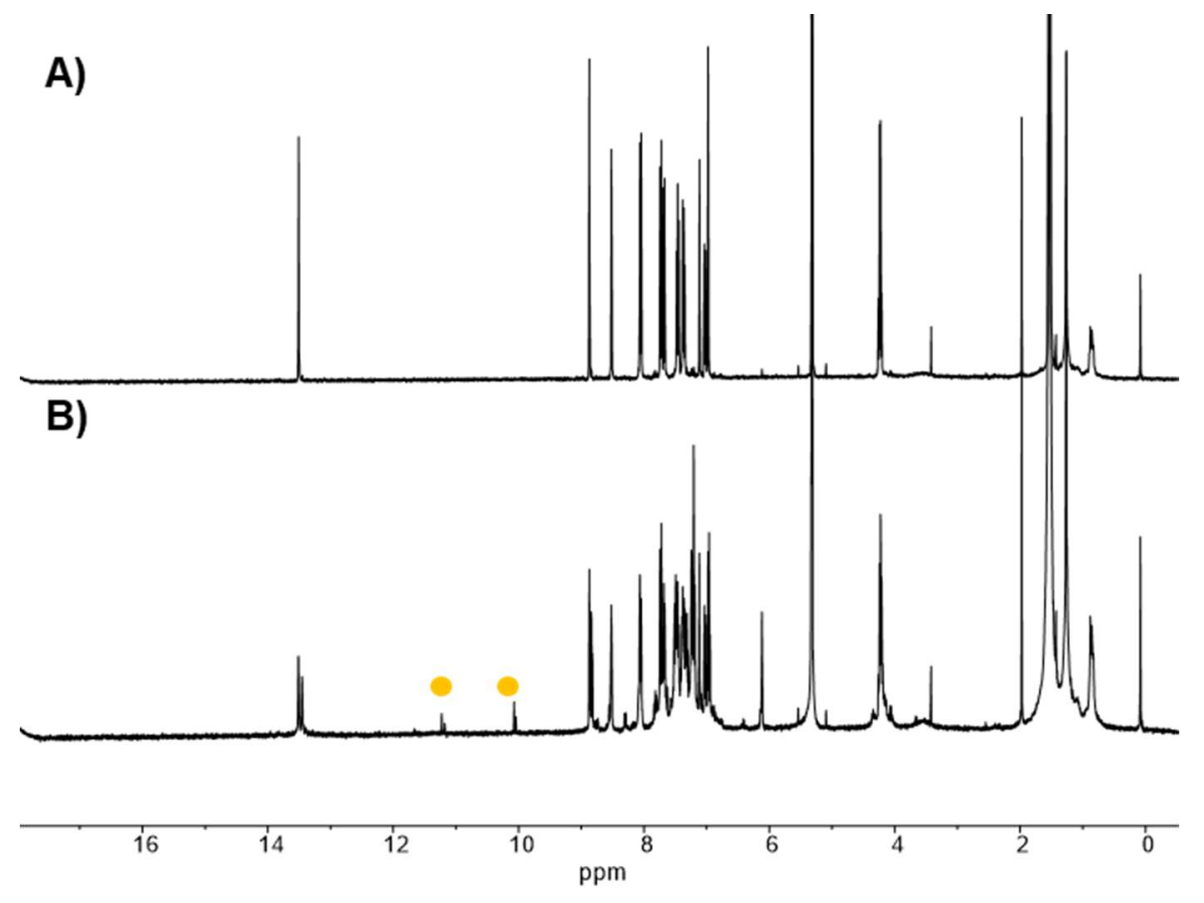

Figure S46. ${ }^{1} \mathrm{H}$ NMR spectra $\left(400 \mathrm{MHz}, 25^{\circ} \mathrm{C}, \mathrm{DCM}-\mathrm{d}_{2}\right)$ of $\left.6 \mathrm{~A}\right)$ before and $\left.\mathrm{B}\right)$ after irradiation with $256 \mathrm{~nm}$ light $(1 \mathrm{~h})$. Yellow dots are hydrolysis by-products. 


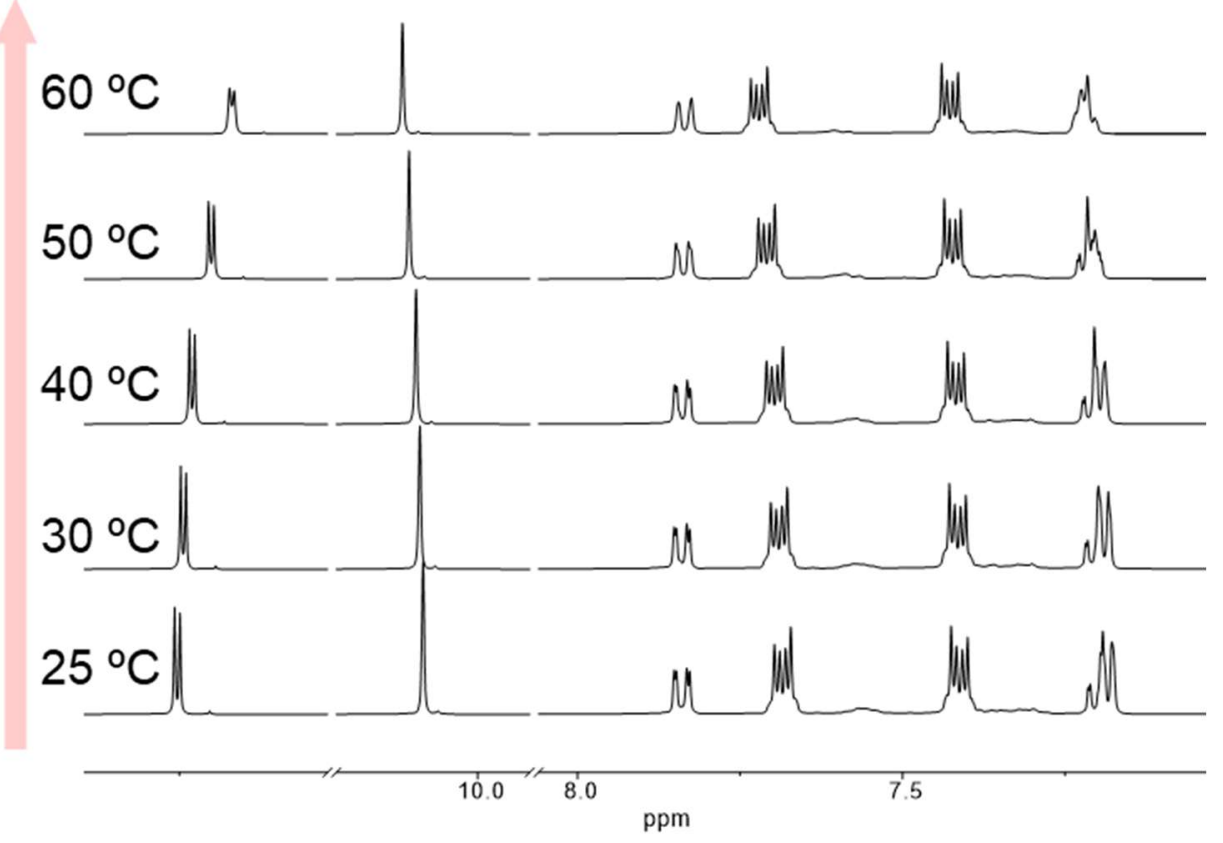

Figure S47. Partial stacked VT ${ }^{1} \mathrm{H}$ NMR spectra $\left(400 \mathrm{MHz}, \mathrm{CDCl}_{3}\right)$ of 2 from 25 to $60^{\circ} \mathrm{C}$.

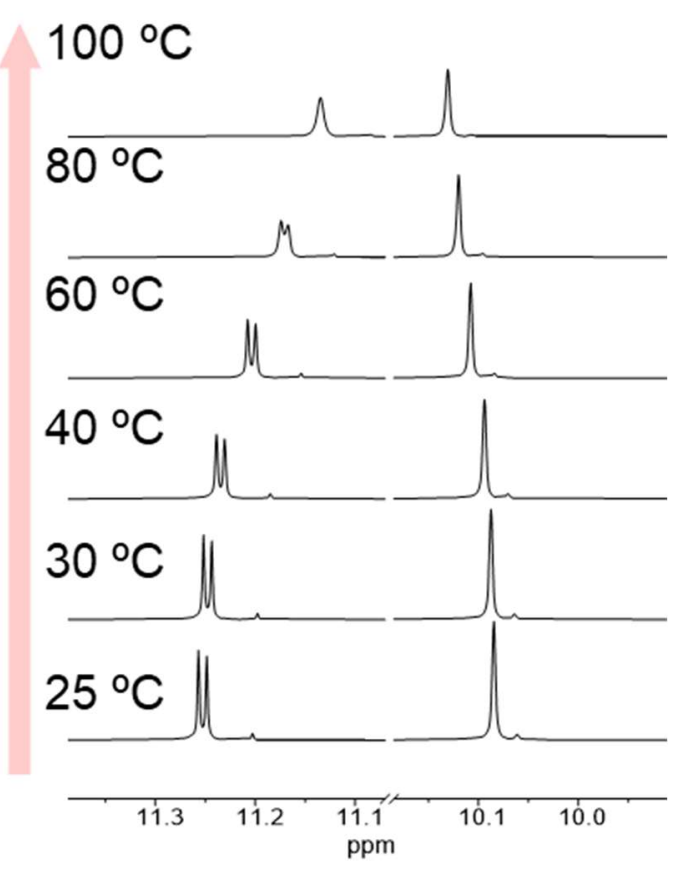

Figure S48. Partial stacked VT ${ }^{1} \mathrm{H}$ NMR spectra (400 MHz, 1,1,2,2-TCE- $\left.d_{2}\right)$ of 2 from 25 to $100^{\circ} \mathrm{C}$. 


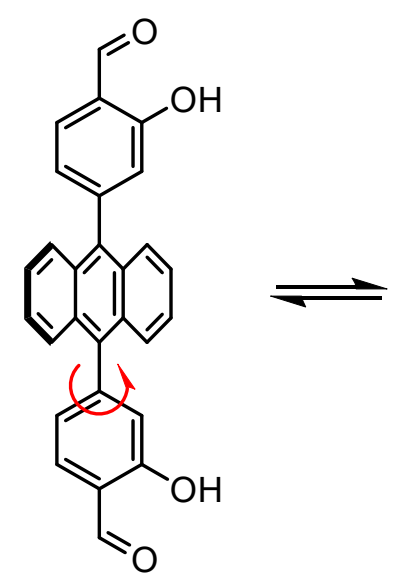

2-syn<smiles>O=Cc1ccc(-c2ccccc2-c2ccccc2-c2ccccc2-c2ccc(C=O)c(C=O)c2)cc1O</smiles>

2-anti

Scheme S5. Rotation of 2 (syn to anti).

VT NMR spectroscopy on 2-syn was done to determine the origin for $\mathrm{H}_{\mathrm{a}}$ (hydroxyl) appearing as a doublet (Figure S47 and Figure S48). Hindered rotation around the anthracene unit results in two stable conformers, 2-syn and 2-anti. Upon heating the sample from 25 to $60^{\circ} \mathrm{C}$, there is a small decrease in the distance between the two overlapping singlets. At $100^{\circ} \mathrm{C}\left(1,1,2,2-\mathrm{TCE}-d_{2}\right)$ we see coalescence of the two resonances. However, there is also shifting of the resonance upfield, which prevents calculation of thermodynamic parameters. Luckily computationally we were able to study 2-syn and 2-anti, discussed below in the computational section.

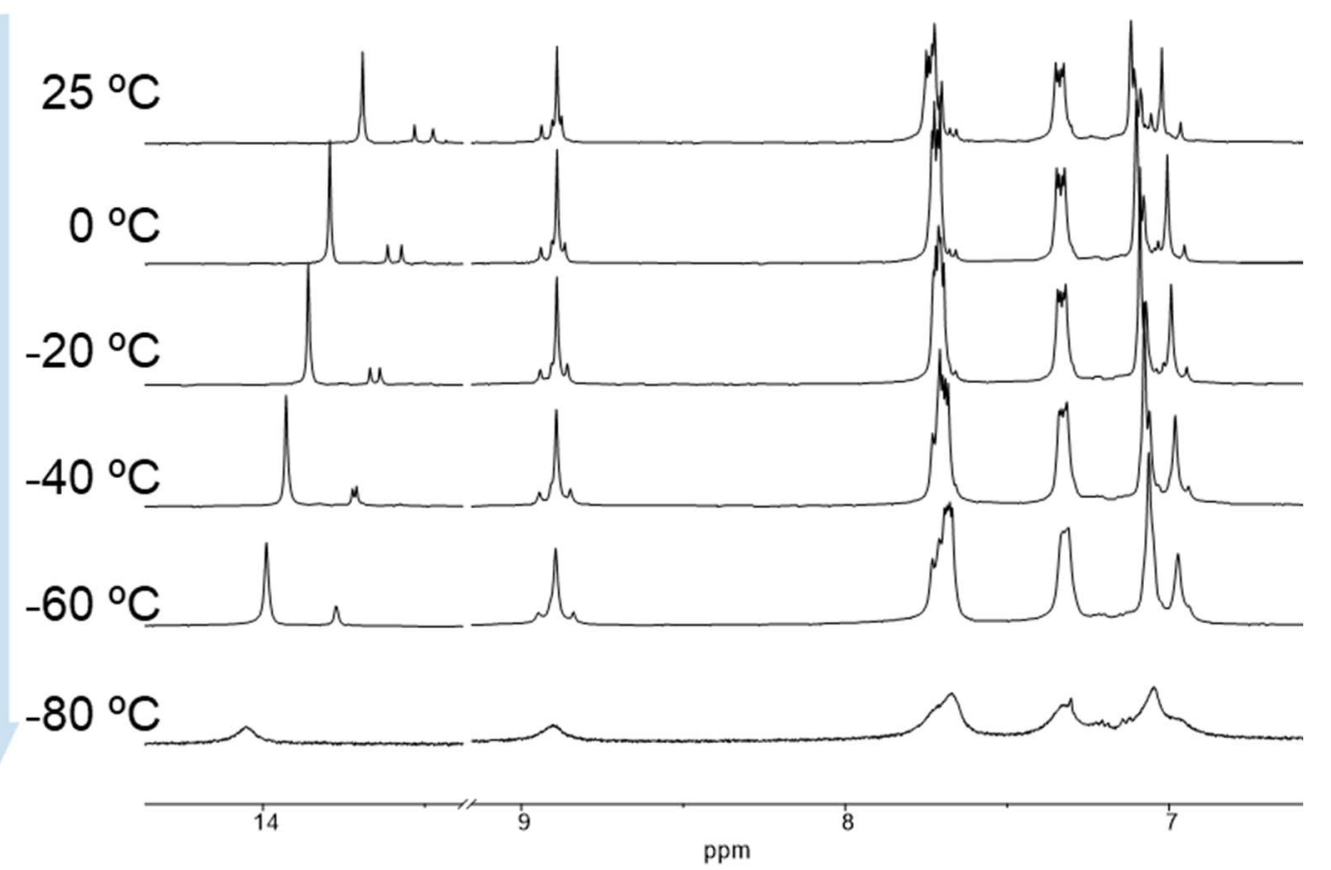

Figure S49. Partial stacked VT ${ }^{1} \mathrm{H}$ NMR spectra (400 MHz, DCM- $d_{2}$ ) of 1 from 25 to $-80{ }^{\circ} \mathrm{C}$. 


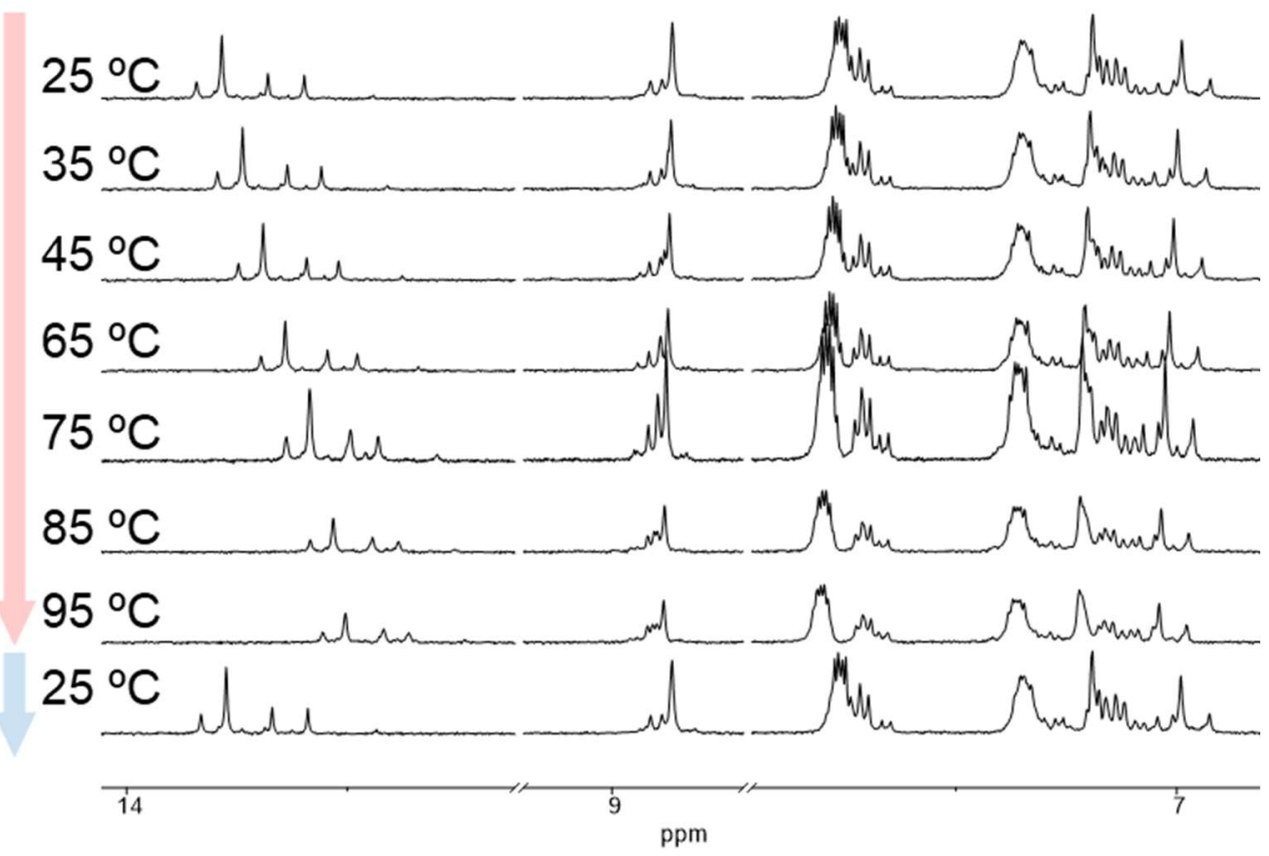

Figure S50. Partial stacked VT ${ }^{1} \mathrm{H}$ NMR spectra ( $\left.400 \mathrm{MHz}, 1,1,2,2-\mathrm{TCE}-d_{2}\right)$ of 1 from 25 up to $95^{\circ} \mathrm{C}$, then back down to $25^{\circ} \mathrm{C}$.

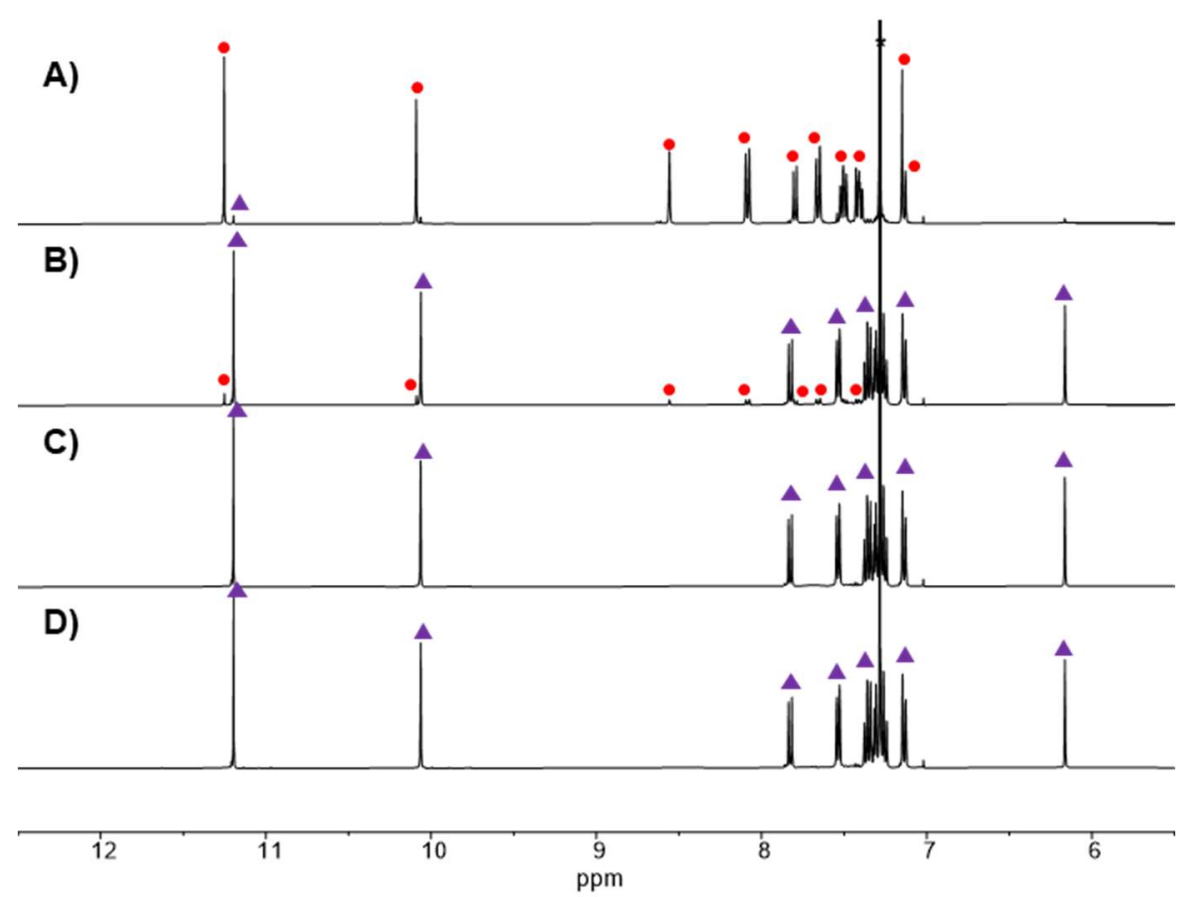

Figure S51. Partial stacked ${ }^{1} \mathrm{H}$ NMR spectra $\left(400 \mathrm{MHz}, 25^{\circ} \mathrm{C}, \mathrm{CDCl}_{3}\right)$ for the conversion of 5 (red circles) into $5 \cdot \mathrm{O}_{2}$ (purple triangles) using $\mathrm{MB}-\mathrm{Cl}(5 \mathrm{~mol} \%$ ) and $600 \mathrm{~nm}$ light. A) $\left.0 \mathrm{~h}, \mathrm{~B}) 1 \mathrm{~h}, \mathrm{C}\right) 2 \mathrm{~h}$, and D) $24 \mathrm{~h}$ under ambient light. 


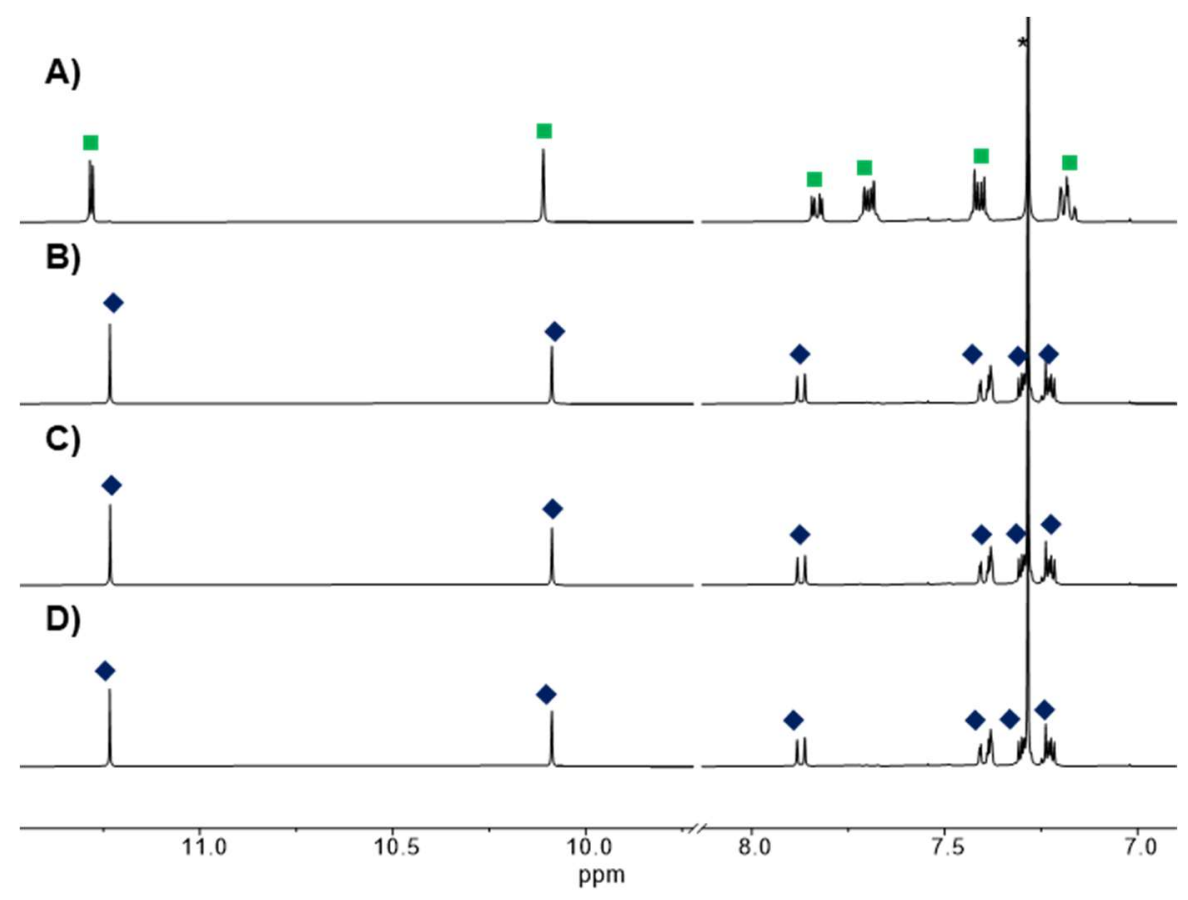

Figure S52. Partial stacked ${ }^{1} \mathrm{H}$ NMR spectra $\left(400 \mathrm{MHz}, 25^{\circ} \mathrm{C}, \mathrm{CDCl}_{3}\right.$ ) for the conversion of 2 (green squares) into $2 \cdot \mathrm{O}_{2}$ (blue diamonds) using $\mathrm{MB}-\mathrm{Cl}(5 \mathrm{~mol} \%)$ and $600 \mathrm{~nm}$ light. A) $\left.\left.0 \mathrm{~h}, \mathrm{~B}\right) 1 \mathrm{~h}, \mathrm{C}\right) 2 \mathrm{~h}$, and D) $24 \mathrm{~h}$ under ambient light.

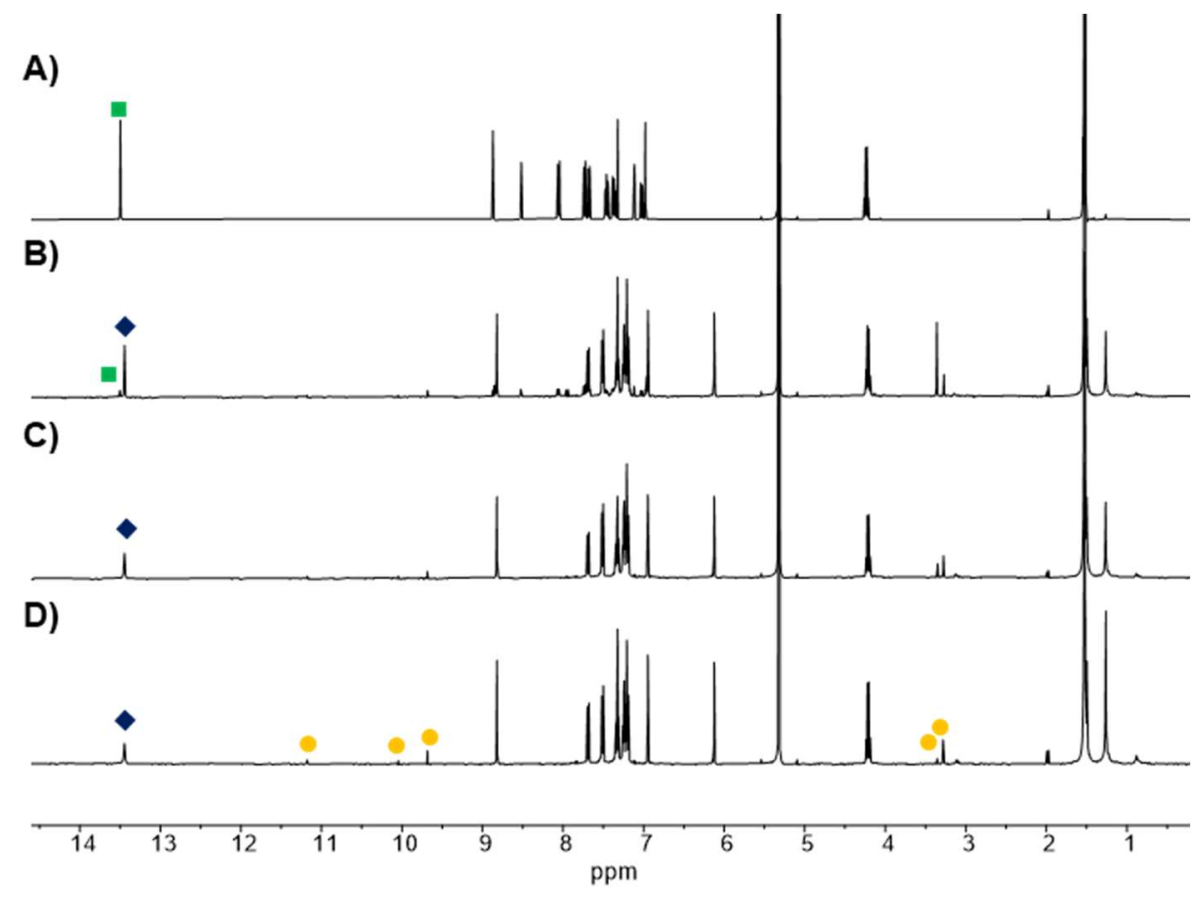

Figure S53. Partial stacked ${ }^{1} \mathrm{H}$ NMR spectra $\left(400 \mathrm{MHz}, 25^{\circ} \mathrm{C}, \mathrm{DCM}-\mathrm{d}_{2}\right)$ for the conversion of 6 (green squares) into $6 \cdot\left(\mathrm{O}_{2}\right)_{2}$ (blue diamonds) using $\mathrm{MB}-\mathrm{Cl}(5 \mathrm{~mol} \%)$ and $600 \mathrm{~nm}$ light. A) $\left.\left.0 \mathrm{~h}, \mathrm{~B}\right) 0.5 \mathrm{~h}, \mathrm{C}\right) 1.0 \mathrm{~h}$, and $\mathrm{D}) 1.5 \mathrm{~h}$. Yellow circles show decomposition products that form during the reaction. 


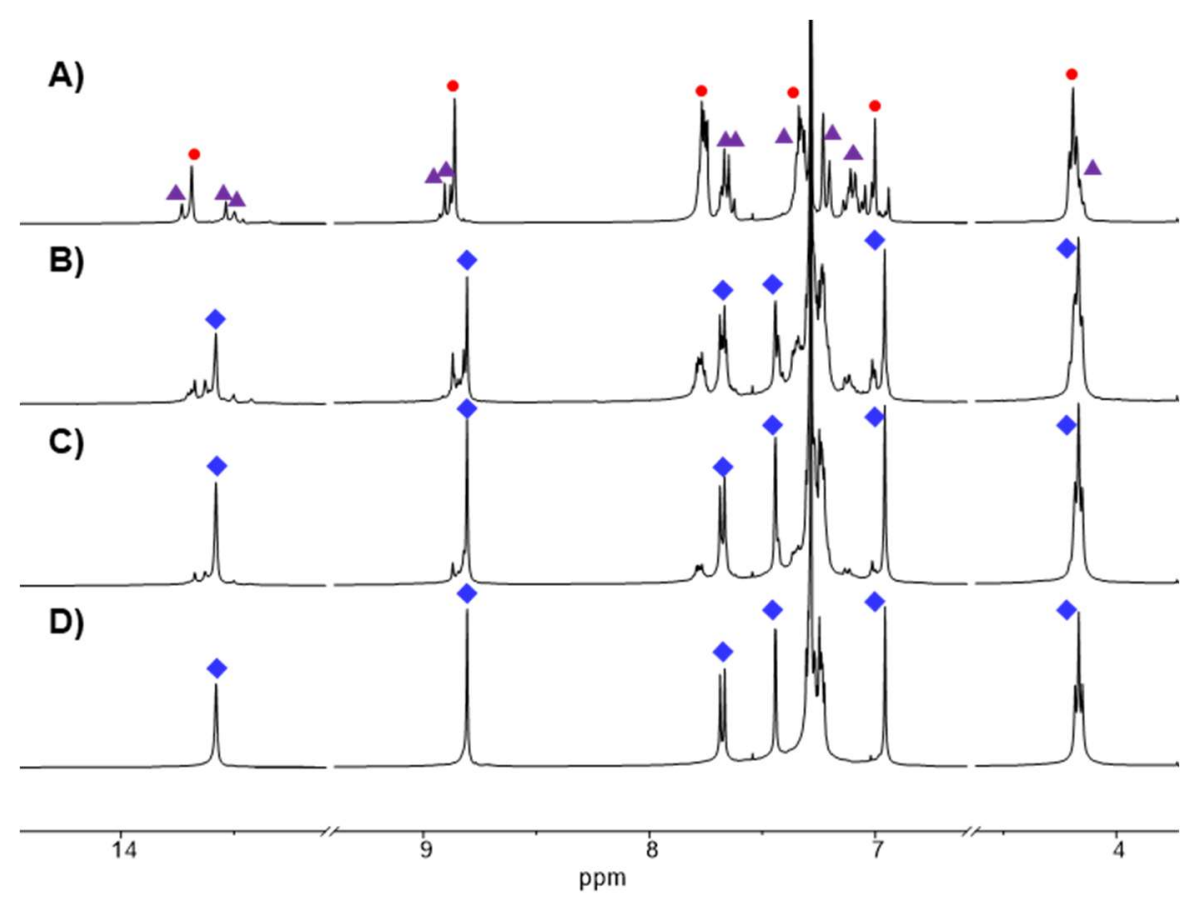

Figure S54. Partial stacked ${ }^{1} \mathrm{H}$ NMR spectra $\left(400 \mathrm{MHz}, 25^{\circ} \mathrm{C}, \mathrm{CDCl}_{3}\right)$ for the conversion of 1 (red circles) and 1' (purple triangles) into 1· $\left(\mathrm{O}_{2}\right)_{3}$ (blue diamonds) using $\mathrm{MB}-\mathrm{Cl}(5 \mathrm{~mol} \%)$ and $600 \mathrm{~nm}$ light. A) $\left.0 \mathrm{~h}, \mathrm{~B}\right) 1$ $\mathrm{h}, \mathrm{C)} 2 \mathrm{~h}$, and D) $4 \mathrm{~h}$.

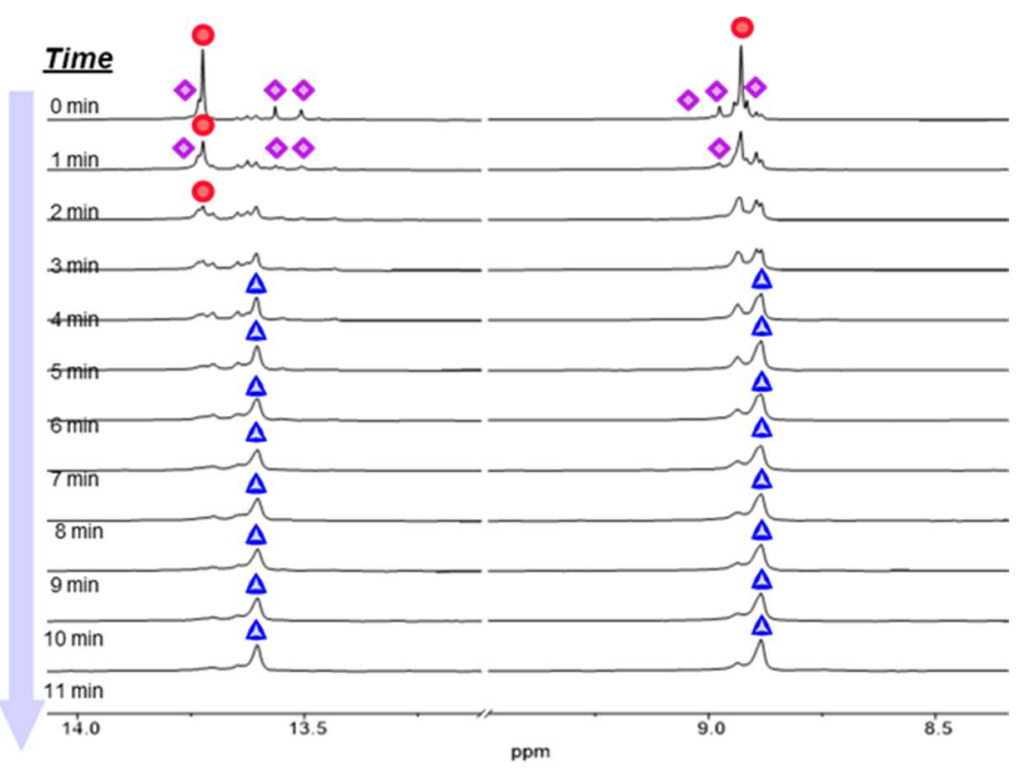

Figure S55. Time gated reaction for 1 to 4 (first 11 minutes of the reaction). Partial stacked ${ }^{1} \mathrm{H}$ NMR spectra $\left(400 \mathrm{MHz}, 25^{\circ} \mathrm{C}, \mathrm{CDCl}_{3}\right)$ for the conversion of 1 (red circles) and 1' (purple diamonds) into 1·( $\left.\mathrm{O}_{2}\right)_{3}$ (blue triangles) using $\mathrm{MB}-\mathrm{Cl}(5 \mathrm{~mol} \%)$ and $600 \mathrm{~nm}$ light. 


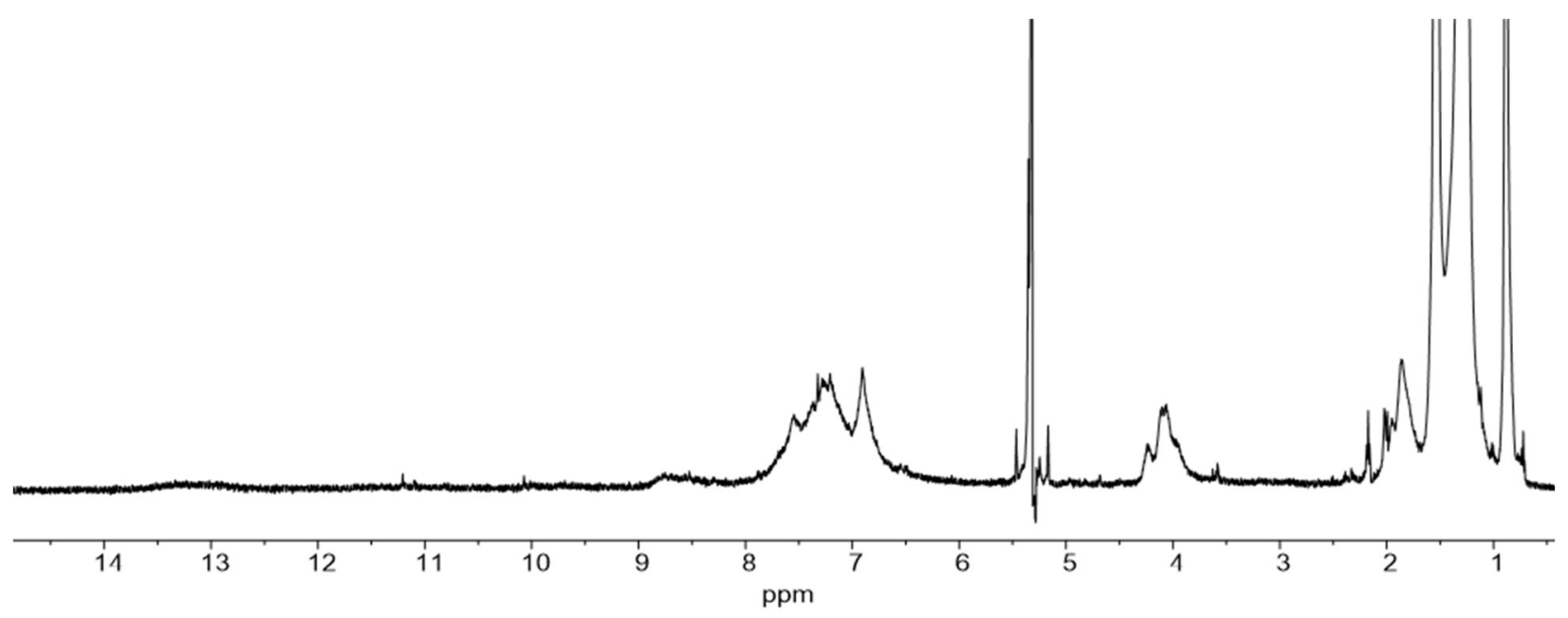

Figure S56. ${ }^{1} \mathrm{H}$ NMR spectrum (400 MHz, $\left.25^{\circ} \mathrm{C}, \mathrm{DCM}-d_{2}\right)$ of 4 after two weeks in situ.

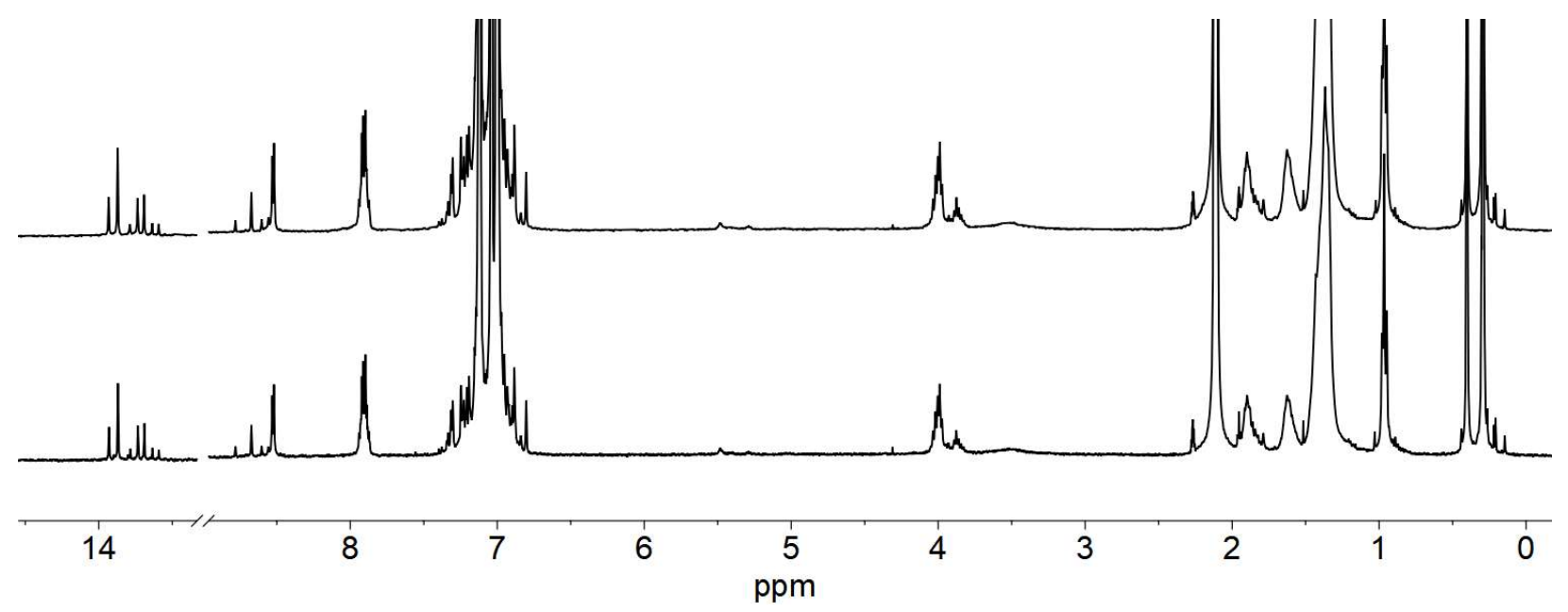

Figure S57. Partial stacked ${ }^{1} \mathrm{H}$ NMR spectra $\left(400 \mathrm{MHz}, 25^{\circ} \mathrm{C}\right.$, PhMe- $\left.d_{8}\right)$ for 1 . Top) no heating. Bottom) heating at $90{ }^{\circ} \mathrm{C}$ for $48 \mathrm{~h}$.

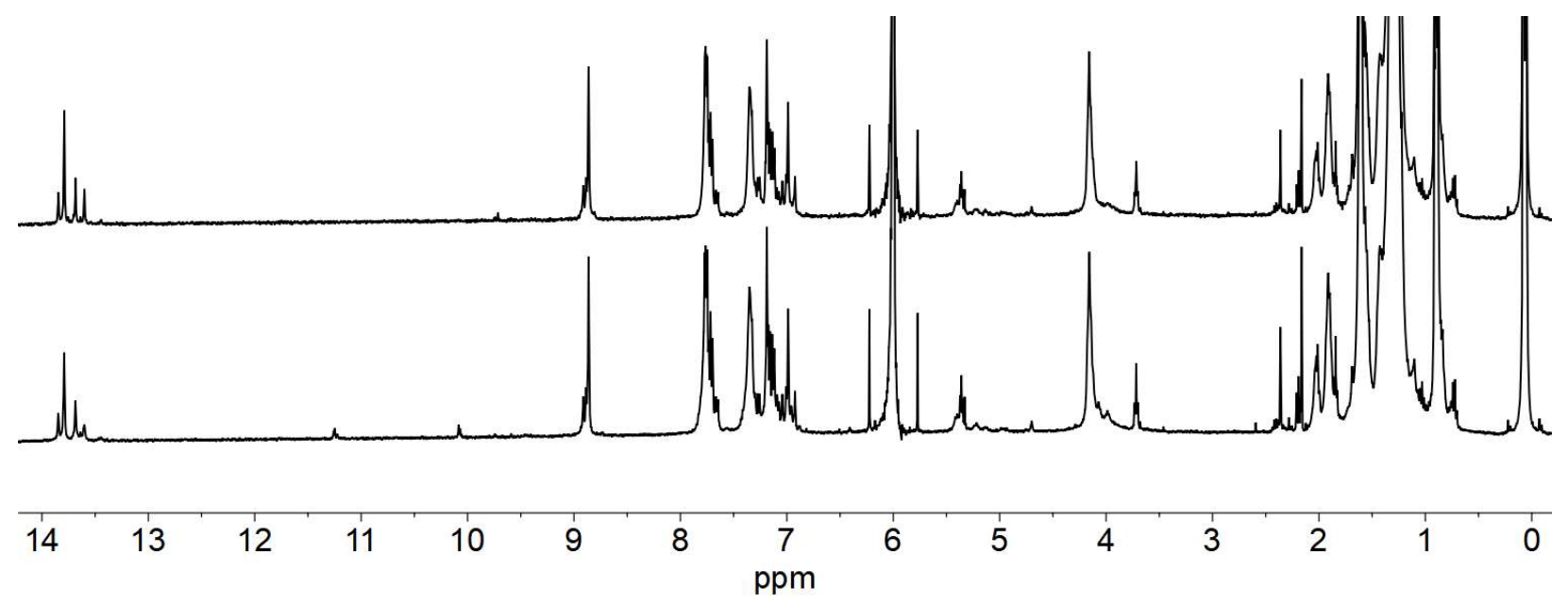

Figure S58. Partial stacked ${ }^{1} \mathrm{H}$ NMR spectra $\left(400 \mathrm{MHz}, 25^{\circ} \mathrm{C}, 1,1,2,2-\mathrm{TCE}-\mathrm{d}_{2}\right)$ for 1 . Top) no heating. Bottom) heating at $90^{\circ} \mathrm{C}$ for $48 \mathrm{~h}$. 


\section{MALDI-TOF MS}

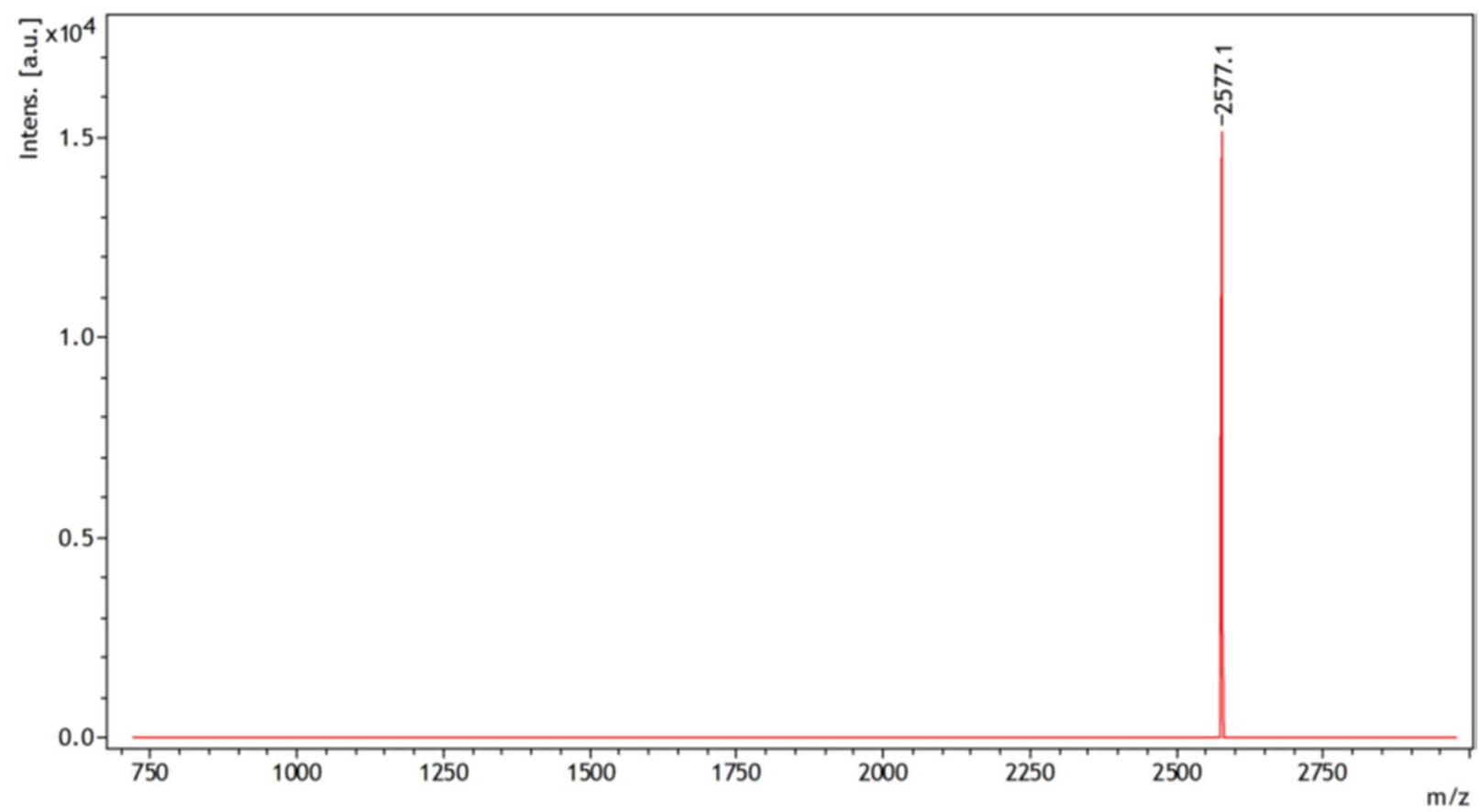

Figure S59. MALDI-TOF mass spectrum (matrix: dctb) of 1/1'.
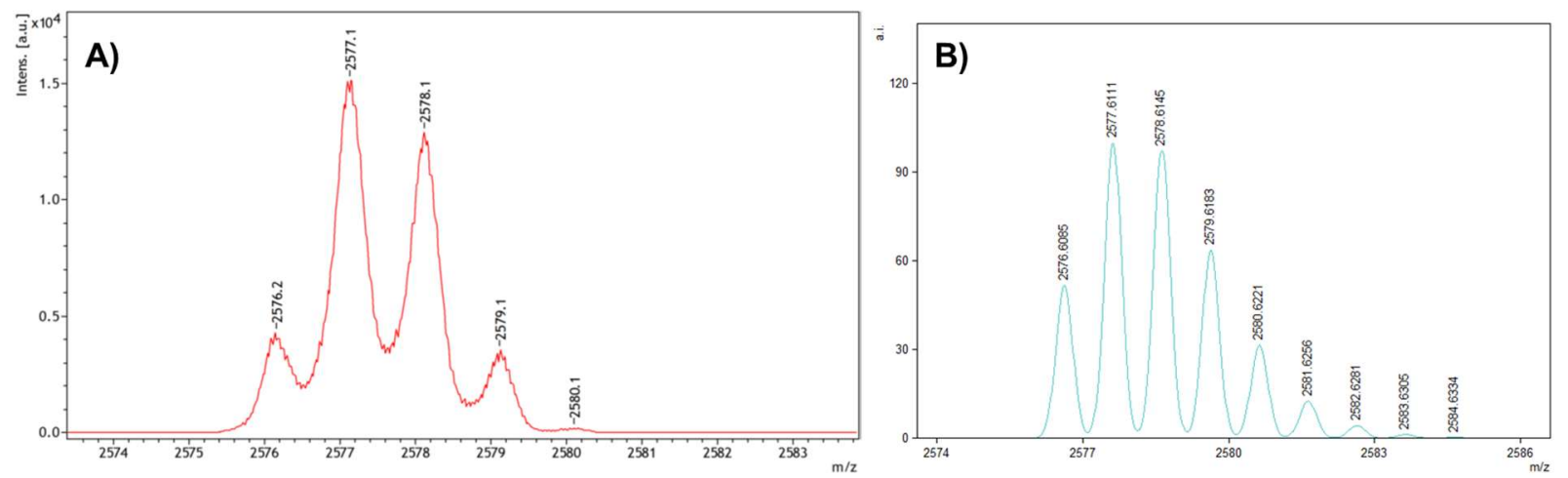

Figure S60. MALDI-TOF mass spectrum (matrix: dctb) of 1/1'. A) Experimental data. B) Calculated isotopic distribution for $1 / 1$ '. 


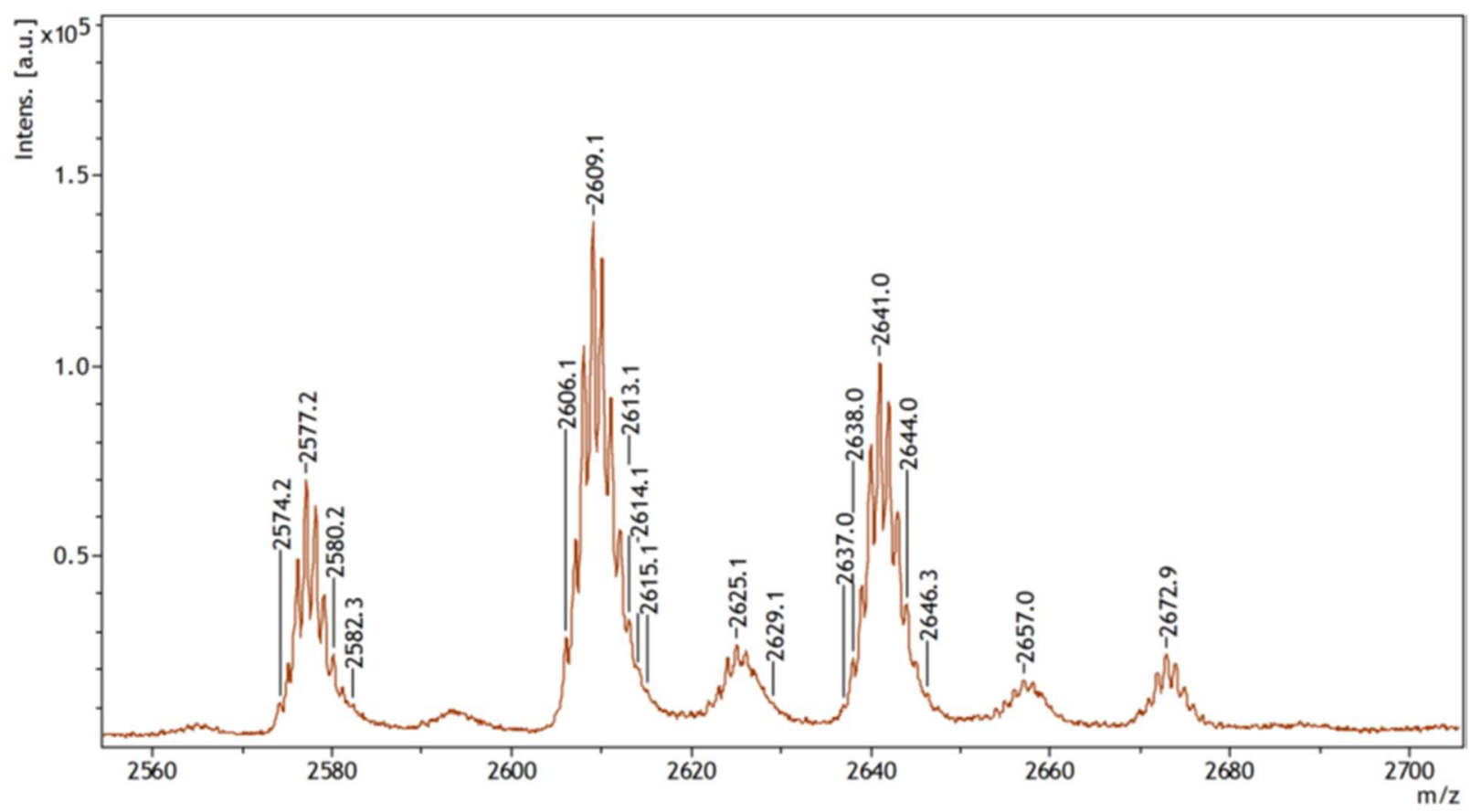

Figure S61. MALDI-TOF mass spectrum (matrix: dctb) of 4. Most peaks are for $1+\left(\mathrm{O}_{2}\right)_{\mathrm{n}}$, which forms due to the strong laser source used in MALDI-TOF.
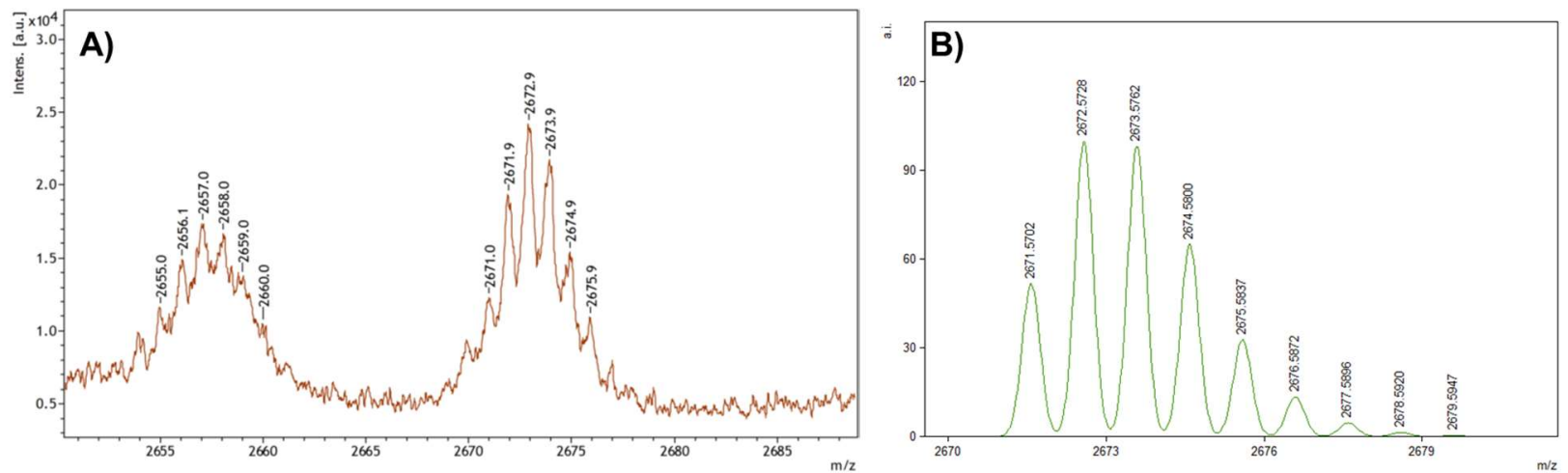

Figure S62. MALDI-TOF mass spectrum (matrix: dctb) of 4. A) Experimental data. B) Calculated isotopic distribution for 4 


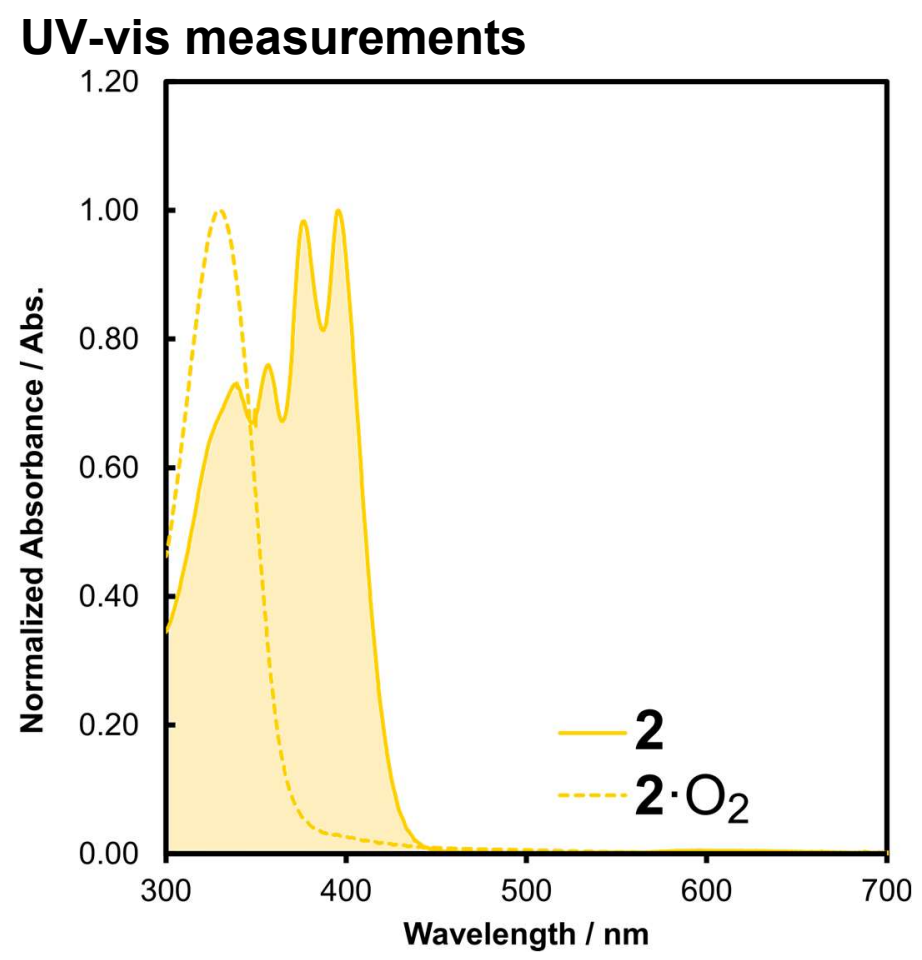

Figure S63. Normalized absorbance spectra of 2 and $\mathbf{2} \cdot \mathrm{O}_{2}$ in DCM.

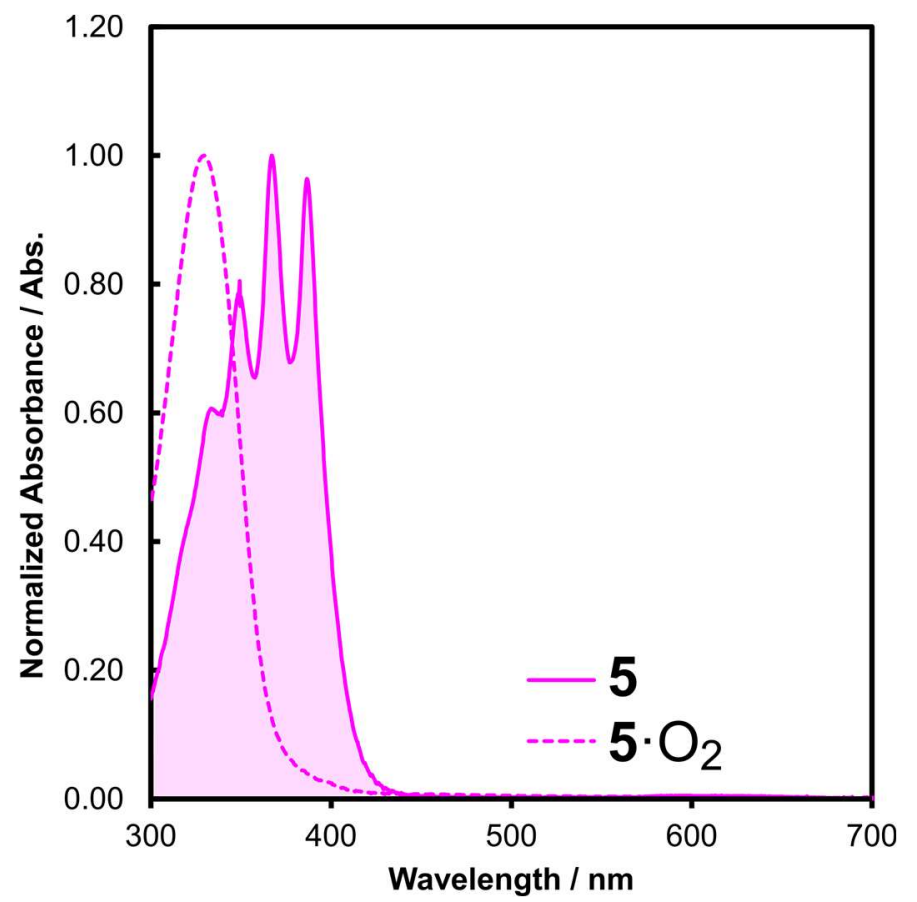

Figure S64. Normalized absorbance spectra of $\mathbf{5}$ and $\mathbf{5} \cdot \mathrm{O}_{2}$ in DCM. 


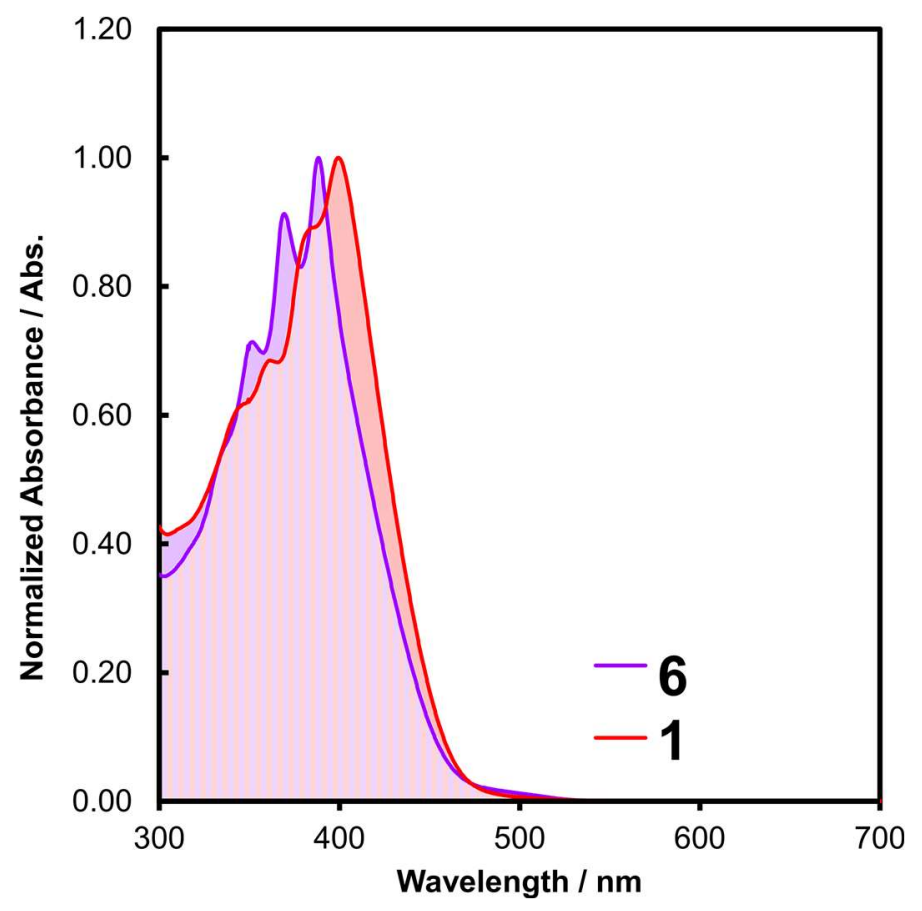

Figure S65. Normalized absorbance spectra of $\mathbf{6}$ and $\mathbf{1}$ in DCM.

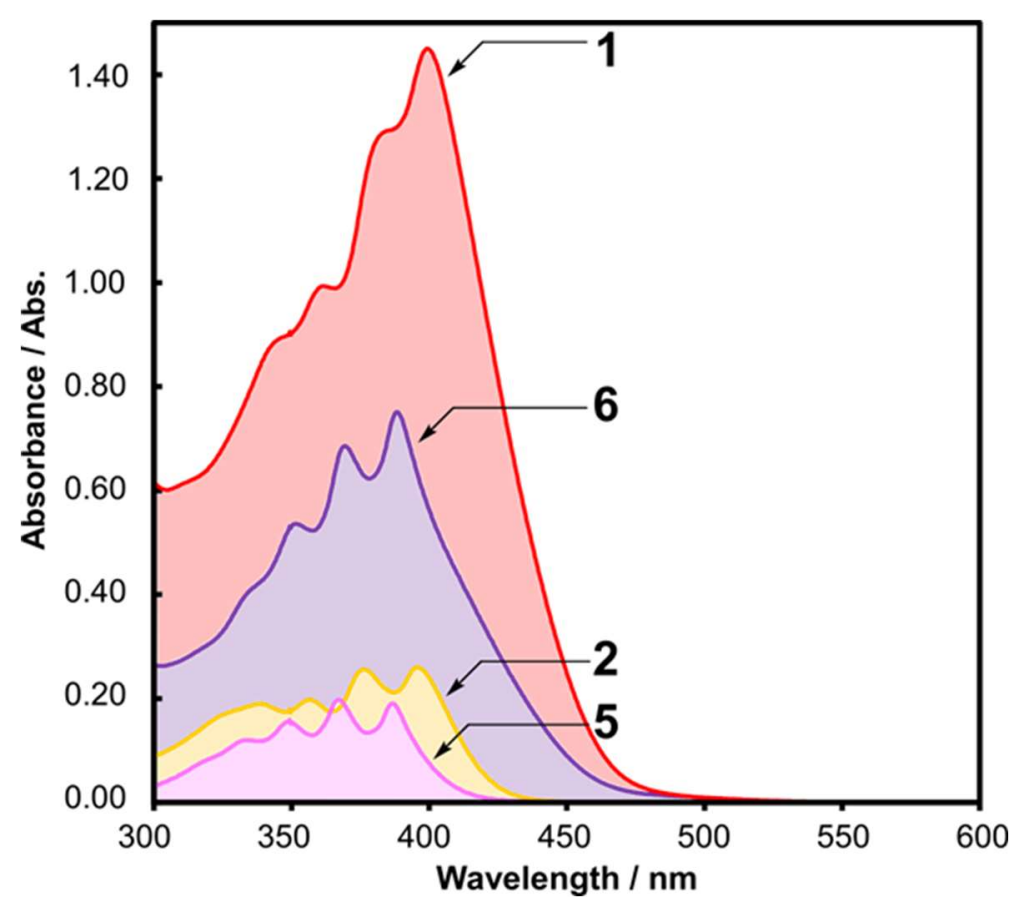

Figure S66. Absorbance spectra of 1, 2, 5, and 6 in DCM (all at $2 \times 10^{-5} \mathrm{M}$ ). 


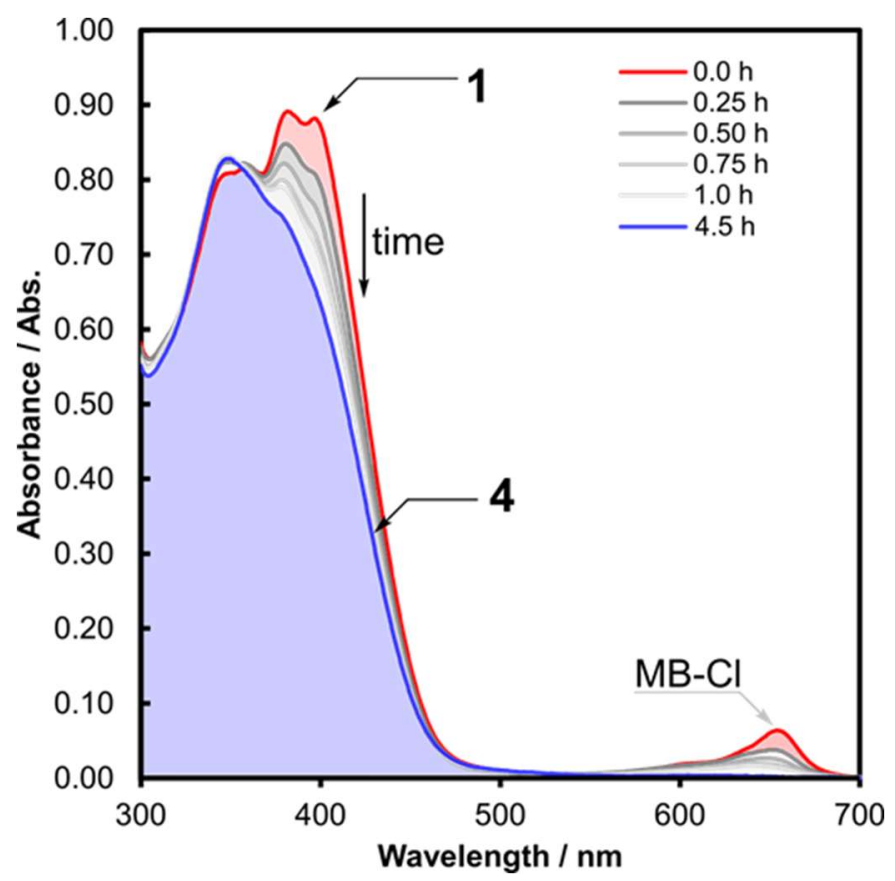

Figure S67. Absorbance spectra (DCM) showing the formation of 4 over time from 1 using MB-Cl (5 $\mathrm{mol} \%$ ) and $600 \mathrm{~nm}$ light.

The experiment was continued until $6.5 \mathrm{~h}$, but no changes occurred after $4.5 \mathrm{~h}$.

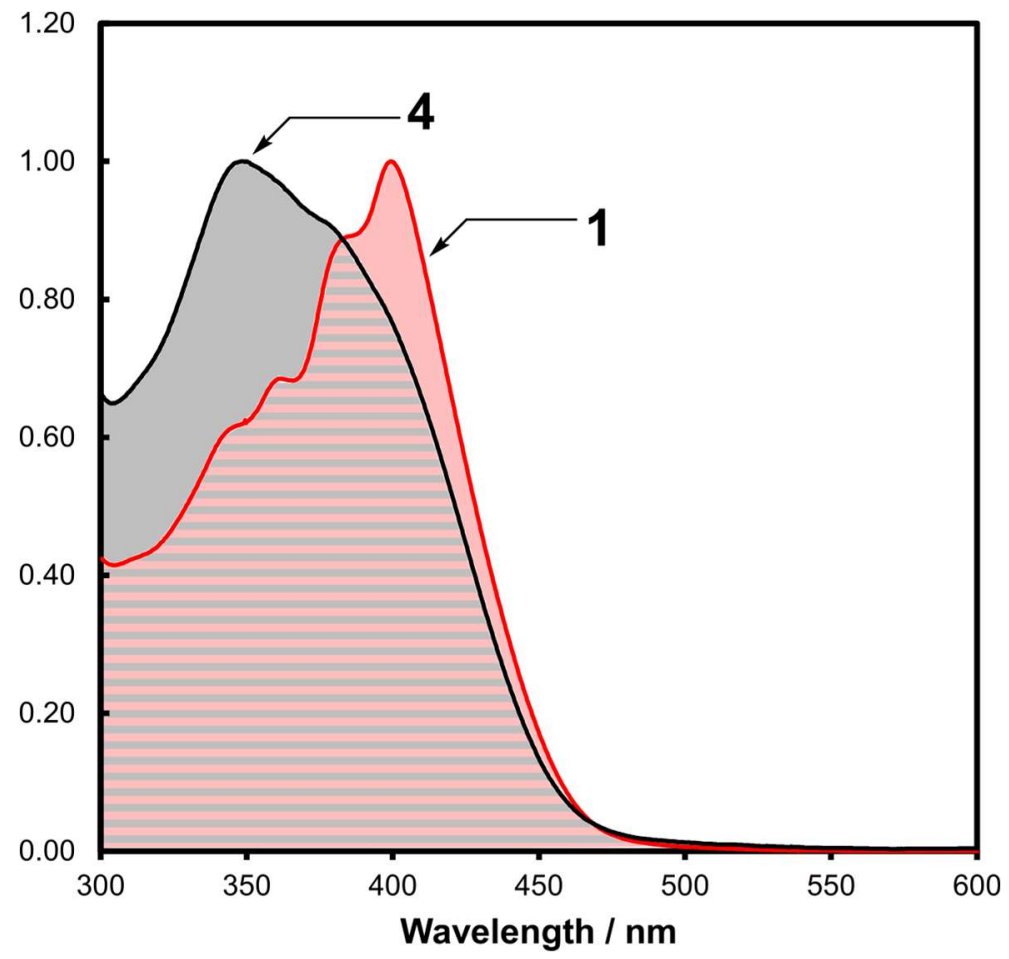

Figure S68. Normalized absorbance spectra of 1 and 4 in DCM. 


\section{SCXRD discussion}

\section{Details for 2}

Crystals were grown via slow evaporation of a solution of $\mathbf{2}$ in $\mathrm{CDCl}_{3}$ in the dark.

One salicylaldehyde moiety was disordered and modelled in parts. AFIX commands were used on this disordered group.

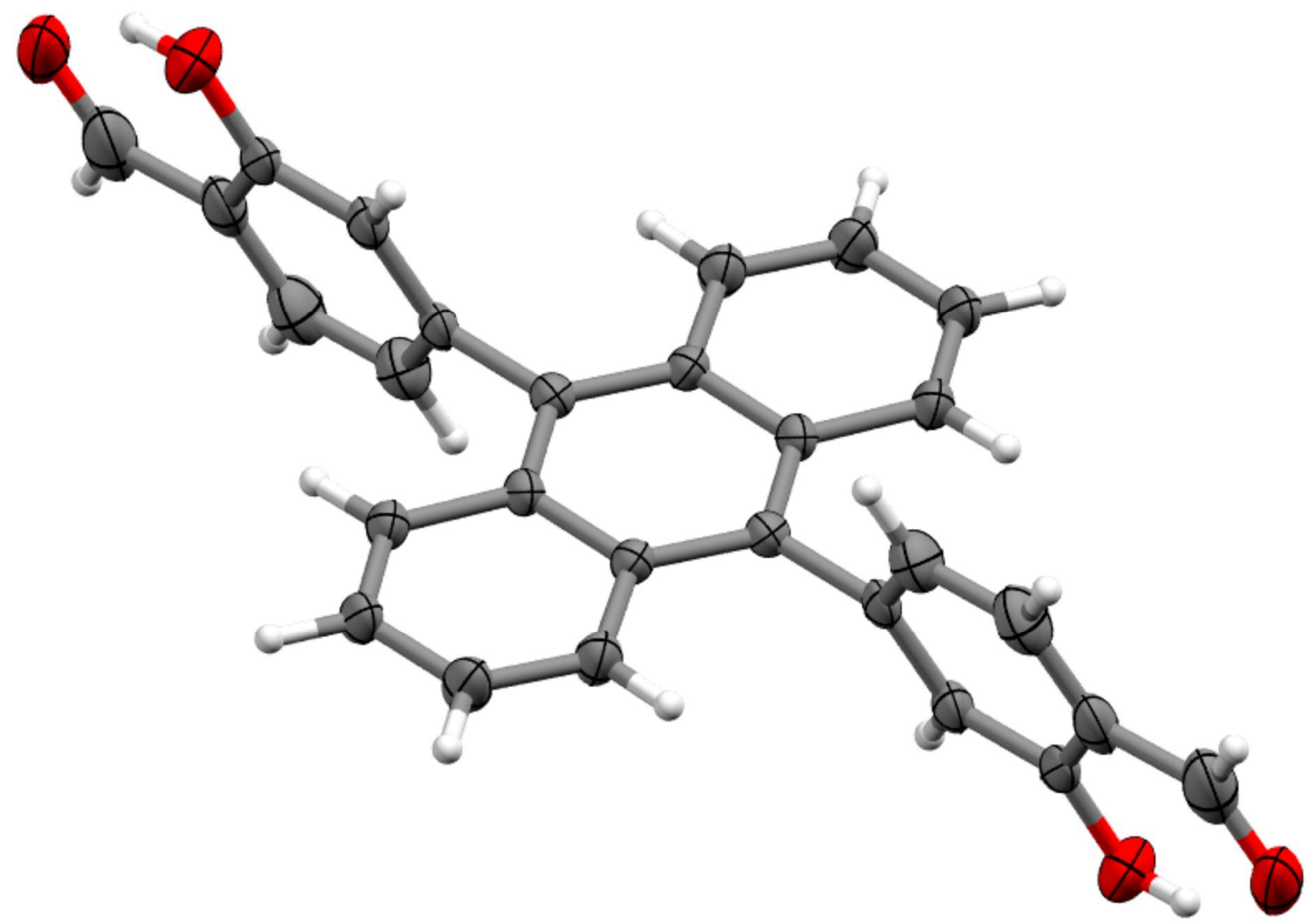

Figure S69. Solid-state molecular structure of 2-anti. Thermal ellipsoids are given at the $50 \%$ probability level.

\section{Details for $2 \cdot \mathrm{O}_{2}$}

Crystals were grown via slow evaporation of a solution of $\mathbf{2}$ in $\mathrm{CDCl}_{3}$ under ambient light.

Very weakly diffracting crystals were obtained, so data could only be collected to a resolution of $0.93 \AA$. 


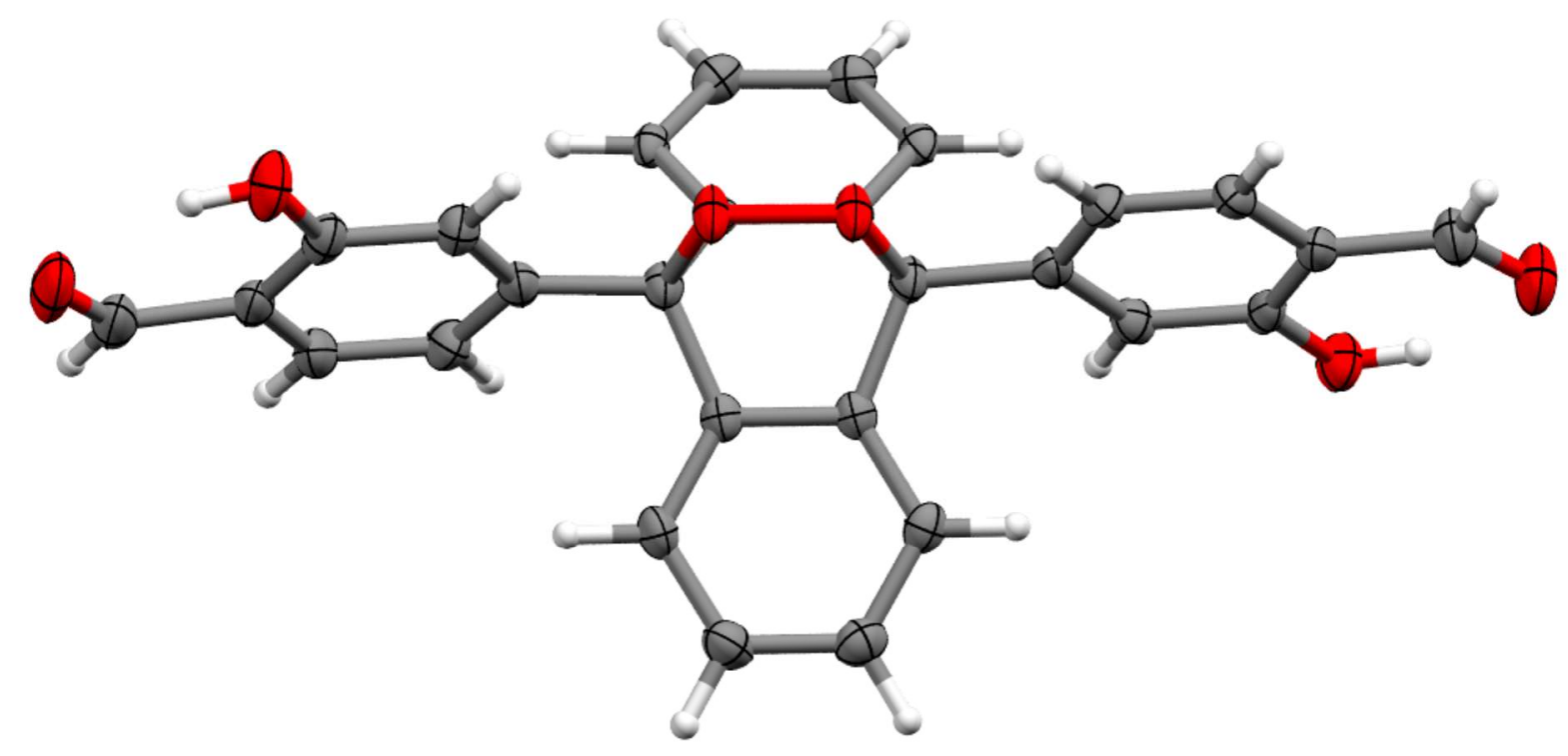

Figure S70. Solid-state molecular structure of $\mathbf{2} \cdot \mathrm{O}_{2}$. Thermal ellipsoids are given at the $50 \%$ probability level.

\section{Details for $\mathbf{5}$}

Crystals were grown via slow evaporation of a solution of $\mathbf{5}$ in DCM and hexanes in the dark. Data were collected to a resolution of $0.70 \AA$, because the crystals were strongly diffracting. 


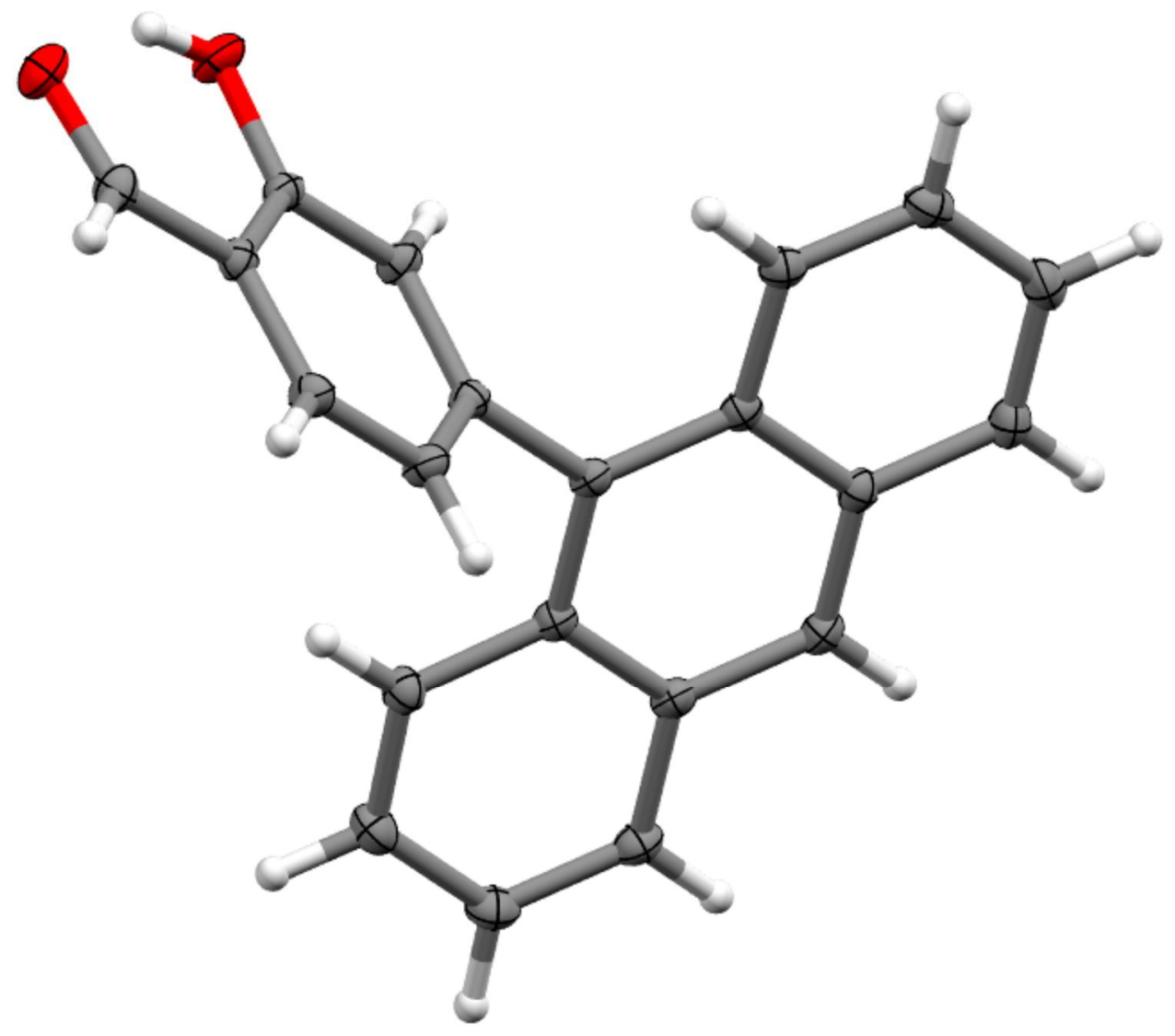

Figure S71. Solid-state molecular structure of $\mathbf{5}$. Thermal ellipsoids are given at the $50 \%$ probability level.

\section{Details for 6-DCM}

Crystals were grown via slow evaporation of a solution of 6 in DCM at $-12^{\circ} \mathrm{C}$ in the dark.

Weakly diffracting crystals were obtained, so data could only be collected to $0.9 \AA$ using Cu-radiation.

A distorted salicyl imine group was modelled in parts, made flat (AFIX 66), and some thermal similarity (EADP) constraints were applied. Electron density for several disordered DCM molecules were accounted for using PLATON/SQUEEZE. The remaining DCM molecule was fixed to 0.5 occupancy. 


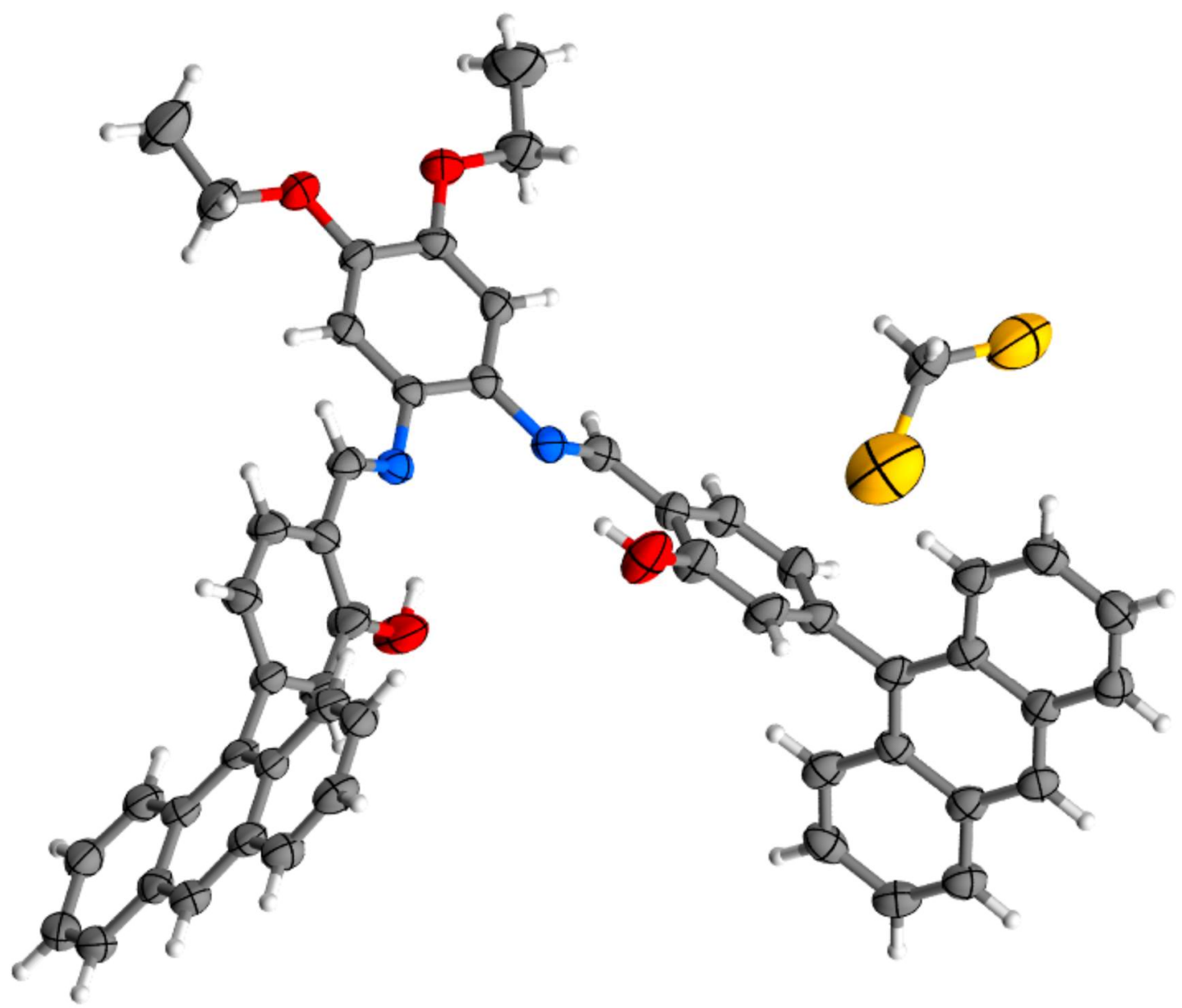

Figure S72. Solid-state molecular structure of 6 . Thermal ellipsoids are given at the $50 \%$ probability level.

\section{Details for 7.DCM- $d_{2}$}

Crystals were grown via slow evaporation of a solution of 7 in DCM- $d_{2}$ and $\mathrm{MeOH}-d_{4}$ under ambient light. Data were collected to a resolution of $0.80 \AA$. A disordered molecule of DCM- $d_{2}$ was modelled in parts. 


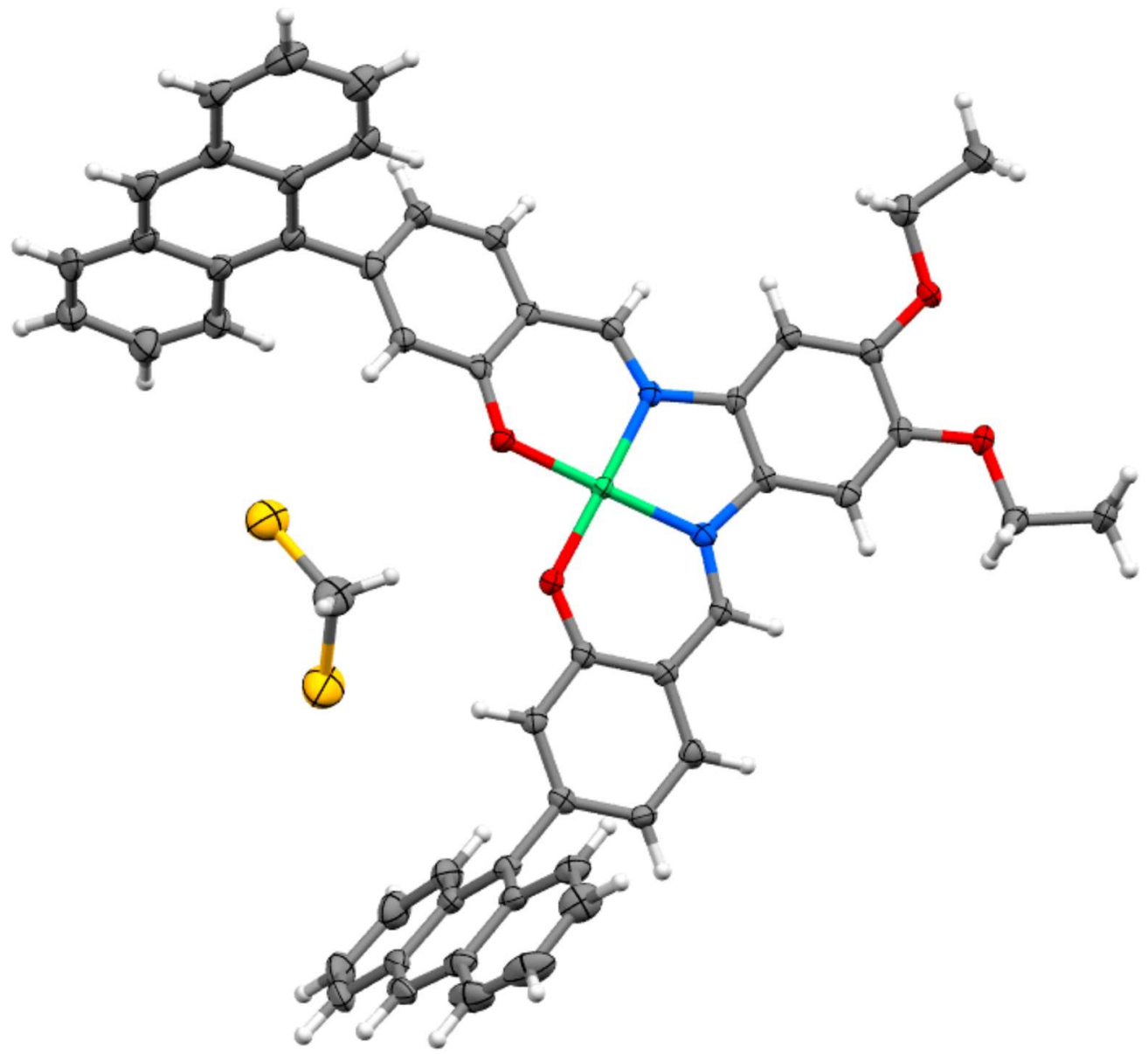

Figure S73. Solid-state molecular structure of $7 \cdot \mathrm{DCM}-d_{2}$. Thermal ellipsoids are given at the $50 \%$ probability level. 
Table 1. Select crystallographic data

\begin{tabular}{|c|c|c|c|c|c|}
\hline Compound & 2 & $2 \cdot \mathrm{O}_{2}$ & 5 & 7.DCM- $d_{2}$ & 6.DCM \\
\hline Empirical formula & $\mathrm{C}_{28} \mathrm{H}_{18} \mathrm{O}_{4}$ & $\mathrm{C}_{28} \mathrm{H}_{18} \mathrm{O} 6$ & $\mathrm{C}_{42} \mathrm{H}_{28} \mathrm{O}_{4}$ & $\begin{array}{c}\mathrm{C}_{53} \mathrm{H}_{38} \mathrm{Cl}_{2} \mathrm{D}_{2} \mathrm{~N}_{2} \mathrm{Ni} \\
\mathrm{O}_{4}\end{array}$ & $\begin{array}{c}\mathrm{C}_{44.86} \mathrm{H}_{34.86} \mathrm{Cl}_{0.57} \\
\mathrm{~N}_{1.71} \mathrm{O}_{3.43}\end{array}$ \\
\hline Formula weight & 418.42 & 450.42 & 596.64 & 900.49 & 673.00 \\
\hline Temperature/K & 100 & 100 & 100 & 100 & 90 \\
\hline Crystal system & triclinic & triclinic & monoclinic & orthorhombic & orthorhombic \\
\hline Space group & $P-1$ & $P-1$ & $\mathrm{C} 2 / \mathrm{c}$ & Pbca & Pbcn \\
\hline$a / \AA ̊$ & $9.0359(10)$ & $9.2487(15)$ & $14.959(2)$ & $18.3576(7)$ & $10.3611(3)$ \\
\hline $\mathrm{b} / \AA$ & $9.7442(11)$ & $10.4030(17)$ & $10.8074(15)$ & $20.3631(6)$ & $39.3790(9)$ \\
\hline$c / \AA ̊$ & $12.8795(14)$ & 11.7065(19) & 18.632(3) & $22.7419(8)$ & $35.0811(9)$ \\
\hline$\alpha /^{\circ}$ & $109.871(3)$ & $70.837(2)$ & 90 & 90 & 90 \\
\hline$\beta /^{\circ}$ & 106.964(3) & $87.127(2)$ & $102.533(4)$ & 90 & 90 \\
\hline $\mathrm{Y} /{ }^{\circ}$ & $93.658(4)$ & $70.808(2)$ & 90 & 90 & 90 \\
\hline Volume $/ \AA^{3}$ & 1003.20(19) & $1002.7(3)$ & $2940.4(7)$ & $8501.3(5)$ & 14313.4(6) \\
\hline Z & 2 & 2 & 4 & 8 & 14 \\
\hline$\rho_{\text {calc }} \mathrm{g} / \mathrm{cm}^{3}$ & 1.385 & 1.492 & 1.348 & 1.407 & 1.093 \\
\hline$\mu / \mathrm{mm}^{-1}$ & 0.092 & 0.105 & 0.086 & 0.633 & 0.876 \\
\hline$F(000)$ & 436 & 468 & 1248 & 3728 & 4944 \\
\hline Crystal size/mm³ & $\begin{array}{c}0.11 \times 0.08 \times \\
0.04\end{array}$ & $\begin{array}{l}0.24 \times 0.15 \\
\quad \times 0.12\end{array}$ & $\begin{array}{c}0.4 \times 0.34 \times \\
0.25\end{array}$ & $\begin{array}{c}0.10 \times 0.10 \times \\
0.10\end{array}$ & $\begin{array}{c}0.32 \times 0.23 \times \\
0.10\end{array}$ \\
\hline Radiation & $\begin{array}{c}\text { MoKa } \\
(\lambda=0.71073)\end{array}$ & $\begin{array}{c}\text { MoKa } \\
(\lambda= \\
0.71073)\end{array}$ & $\begin{array}{c}\text { MoKa } \\
(\lambda= \\
0.71073)\end{array}$ & $\begin{array}{c}\text { MoKa } \\
(\lambda=0.71073)\end{array}$ & $\begin{array}{c}\text { CuKa } \\
(\lambda=1.54178)\end{array}$ \\
\hline $\begin{array}{l}2 \Theta \text { range for data } \\
\text { collection } /{ }^{\circ}\end{array}$ & $\begin{array}{l}3.568 \\
\text { to } 50.834\end{array}$ & $\begin{array}{c}3.692 \\
\text { to } 45.004\end{array}$ & $\begin{array}{c} \\
4.48 \\
\text { to } 61.294\end{array}$ & $\begin{array}{l}3.482 \\
\text { to } 52.85\end{array}$ & $\begin{array}{l}4.488 \text { to } \\
118.122\end{array}$ \\
\hline Index ranges & $\begin{array}{r}-9 \leq h \leq 10 \\
-11 \leq k \leq 11 \\
-15 \leq 1 \leq 15\end{array}$ & $\begin{array}{c}-9 \leq \mathrm{h} \leq 9 \\
-11 \leq \mathrm{k} \leq \\
11,-12 \leq \mathrm{I} \leq \\
12\end{array}$ & $\begin{array}{c}-21 \leq \mathrm{h} \leq \\
21 \\
-15 \leq \mathrm{k} \leq \\
15 \\
-26 \leq \mathrm{I} \leq 26\end{array}$ & $\begin{array}{c}-22 \leq \mathrm{h} \leq 22 \\
-25 \leq \mathrm{k} \leq 24 \\
-28 \leq \mathrm{l} \leq 21\end{array}$ & $\begin{array}{c}-11 \leq h \leq 10 \\
-43 \leq k \leq 43 \\
-39 \leq 1 \leq 33\end{array}$ \\
\hline $\begin{array}{l}\text { Reflections } \\
\text { collected }\end{array}$ & 17751 & 13222 & 35110 & 56541 & 86630 \\
\hline $\begin{array}{l}\text { Independent } \\
\text { reflections }\end{array}$ & $\begin{array}{c}3688\left[\mathrm{R}_{\mathrm{int}}=\right. \\
0.0437 \\
\mathrm{R}_{\text {sigma }}= \\
0.0472]\end{array}$ & $\begin{array}{c}2621\left[R_{\text {int }}=\right. \\
0.0332 \\
R_{\text {sigma }}= \\
0.0232]\end{array}$ & $\begin{array}{c}4541\left[\mathrm{R}_{\text {int }}=\right. \\
0.0647, \\
\mathrm{R}_{\text {sigma }}= \\
0.0399]\end{array}$ & $\begin{array}{c}8729\left[R_{\text {int }}=\right. \\
0.0919, R_{\text {sigma }}= \\
0.0713]\end{array}$ & $\begin{array}{c}10332 \text { [Rint }= \\
0.0682, \\
\text { Rsigma }= \\
0.0379]\end{array}$ \\
\hline $\begin{array}{c}\text { Data/restraints/para } \\
\text { meters }\end{array}$ & $\begin{array}{c}3688 / 719 / 36 \\
2\end{array}$ & $2621 / 0 / 309$ & $4541 / 0 / 209$ & $8729 / 4 / 571$ & $10332 / 0 / 852$ \\
\hline $\begin{array}{c}\text { Goodness-of-fit on } \\
\mathrm{F}^{2}\end{array}$ & 1.077 & 1.042 & 1.046 & 1.022 & 1.068 \\
\hline $\begin{array}{l}\text { Final } R \text { indexes } \\
\quad[l>=2 \sigma(I)]\end{array}$ & $\begin{array}{c}R_{1}=0.0596 \\
w R_{2}= \\
0.1390\end{array}$ & $\begin{array}{c}R_{1}= \\
0.0389 \\
w R_{2}= \\
0.0983\end{array}$ & $\begin{array}{c}R_{1}= \\
0.0461 \\
w R_{2}= \\
0.1279\end{array}$ & $\begin{array}{c}R_{1}=0.0464 \\
w R_{2}=0.0963\end{array}$ & $\begin{array}{l}\mathrm{R} 1=0.1176, \\
\mathrm{wR} 2=0.3199\end{array}$ \\
\hline $\begin{array}{l}\text { Final } R \text { indexes } \\
\text { [all data] }\end{array}$ & $\begin{array}{c}R_{1}=0.0989 \\
w R_{2}= \\
0.1557\end{array}$ & $\begin{array}{c}\mathrm{R}_{1}= \\
0.0490 \\
w R_{2}= \\
0.1049\end{array}$ & $\begin{array}{c}\mathrm{R}_{1}= \\
0.0551 \\
w R_{2}= \\
0.1358\end{array}$ & $\begin{array}{c}R_{1}=0.0952 \\
w R_{2}=0.1153\end{array}$ & $\begin{array}{l}\mathrm{R} 1=0.1400, \\
\mathrm{wR} 2=0.3387\end{array}$ \\
\hline $\begin{array}{l}\text { Largest diff. } \\
\text { peak/hole } \\
\text { / e } \AA^{-3}\end{array}$ & $0.53 /-0.26$ & $0.26 /-0.25$ & $0.47 /-0.21$ & $0.42 /-0.62$ & $1.16 /-0.81$ \\
\hline
\end{tabular}




\section{Computation section}

The Gaussian suite of programs $\mathrm{G} 016$.revC $01^{10}$ was used for all geometry and Hessian matrix calculations. In addition, geometries were computed with the range separated dispersion corrected $\omega B$ $97 x D^{11}$ and ${\mathrm{M} 06^{12}}^{12}$ meta-hybrid $x c$ functional. The basis set for all atoms was $6-31 \mathrm{~g}(\mathrm{~d}, \mathrm{p}),{ }^{13}$ except for smaller molecules, where the cc-pTVZ ${ }^{14}$ basis set was used instead. All structures were confirmed to be minima by computing the corresponding Hessian matrix at the same level of theory. If using the analytical computed Hessian generated maximum displacement larger than the threshold used in the optimization, the structures were further refined and retested. This method was particularly relevant to calculations for macrocycles ( 1 and 4 ), where structures with very small vibration frequencies were seen. All integrals have been computed using the "Ultrafine" integration grid. In some selected cases, calculations have been performed in solvent $\left(\mathrm{CHCl}_{3}\right)$ using the self-consistent reaction field (SCRF) approach for continuum solvent model simulation included in the Gaussian suite of programs. ${ }^{15}$

In the case of macrocycles 1 and $\mathbf{4}$, the alkoxy chains have been replaced by methoxy groups because of their irrelevance to the conformational equilibria of the system as far the macrocycle "core" is concerned. 
Rotation of salicyl moieties in $\mathbf{2}$ and $\mathbf{2} \cdot \mathrm{O}_{2}$
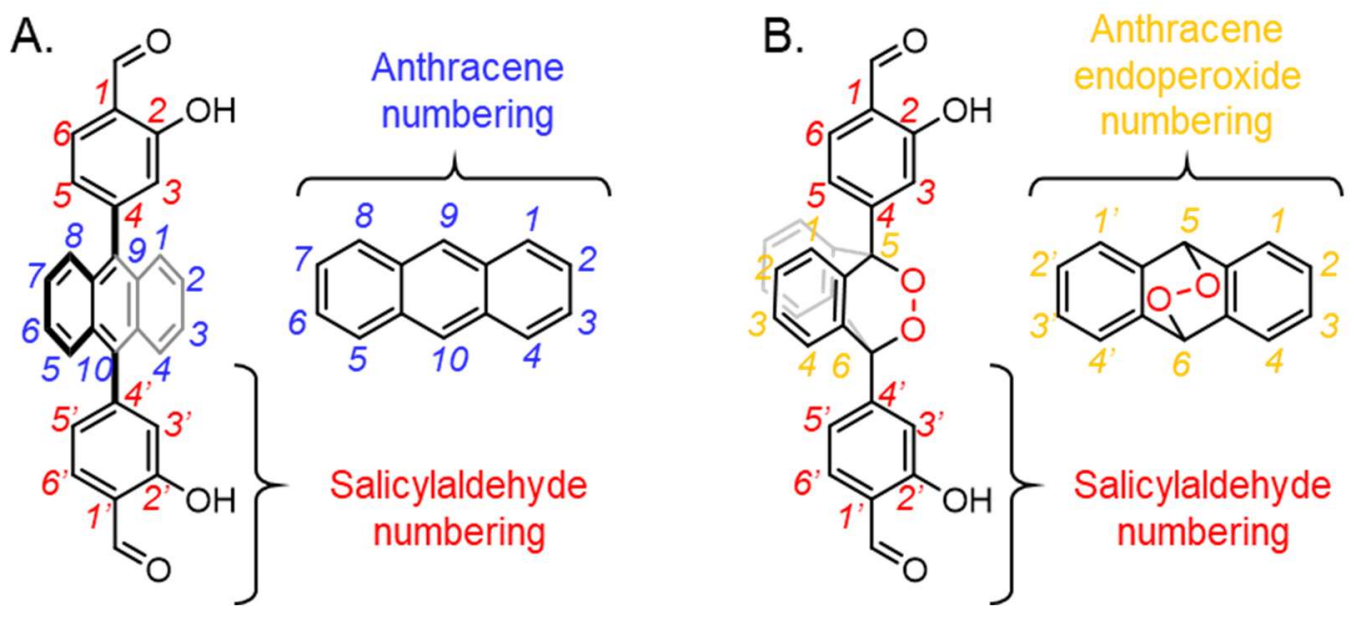

Figure S74. Computational numbering scheme (carbon atoms) for A) $\mathbf{2}$, and $\mathrm{B}) \mathbf{2} \cdot \mathrm{O}_{2}$.

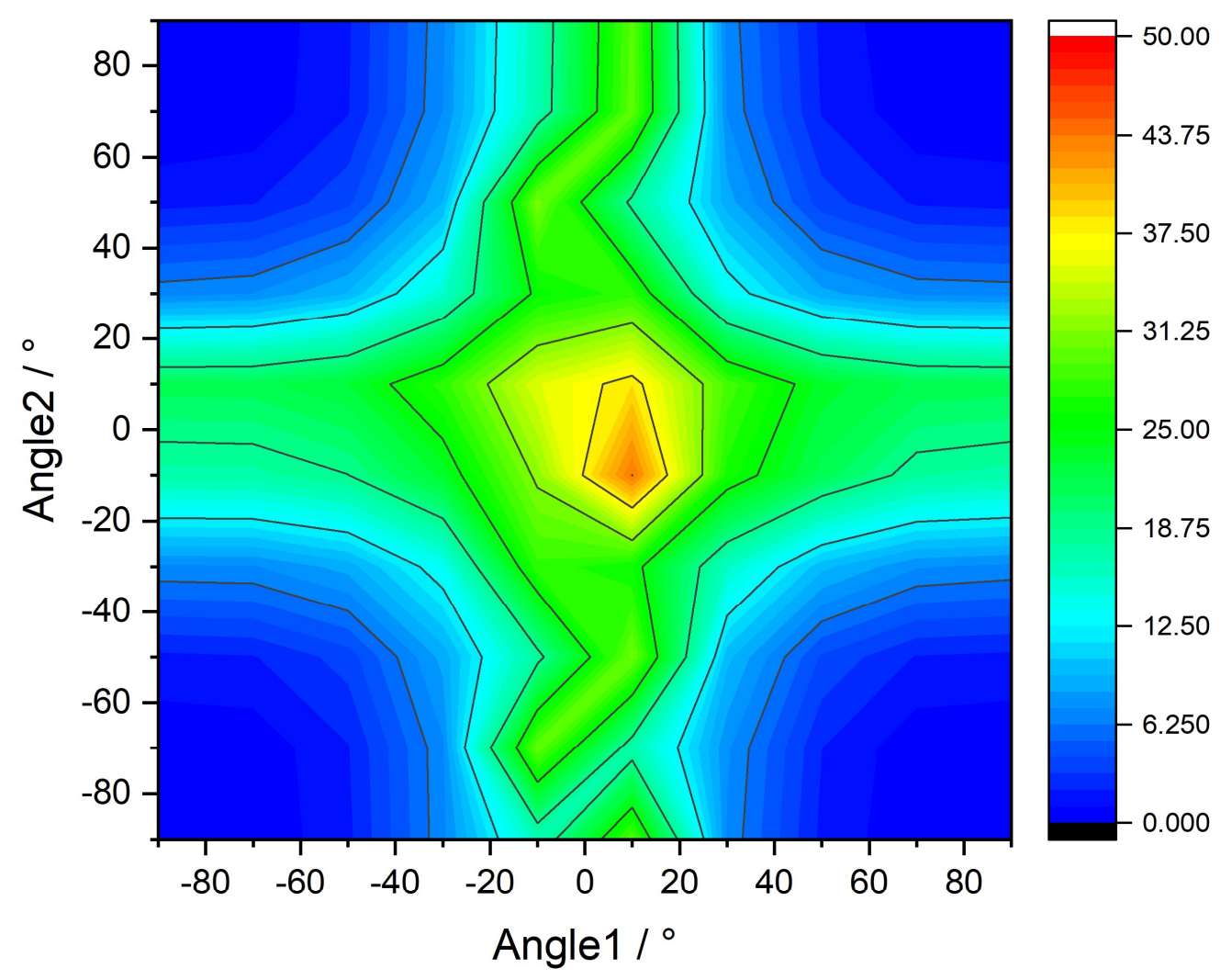

Figure S75. Trend of molecular energy $(\mathrm{kcal} / \mathrm{mol})$ of the torsion energy around (C9-C4) and (C10-C4') bonds (x-axis and $y$-axis of the plot, respectively) computed with a step size of $10^{\circ}$ in case of 2. 
Minima are obtained when the plane of the two salicyl rings are at $90^{\circ}$ relative to the anthracene average plane (Figure S77). Maxima occur when the anthracene and arene rings are coplanar with each other.

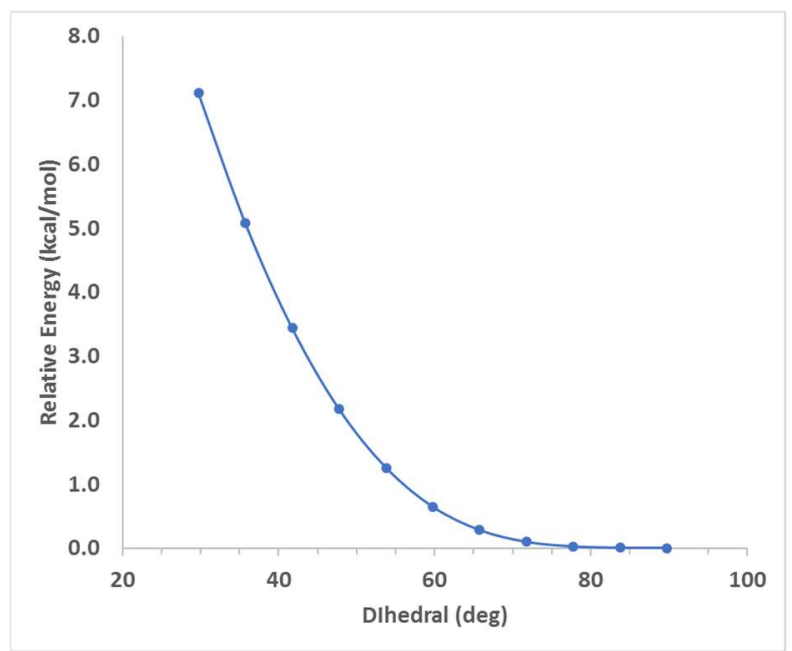

Figure S76. The trend of the molecular energy $(\mathrm{kcal} / \mathrm{mol})$ for the rotation of one salicylaldehyde while the second one is still perpendicular to the anthracene rings plane in case of $\mathbf{2}$. The plot shows that in the ranges $60-90$ and $-90--60 \mathrm{deg}$, the energy landscape is within $1 \mathrm{kT}$ at room temperature.

From Figure S76, we see that rotation around the C4-C9 or C4'-C10 bond occurs easily from ca. $40-90^{\circ}$. The transition state (TS) occurs at a value between $19.4(6-31 \mathrm{~g}(\mathrm{~d}, \mathrm{p}) / \mathrm{M} 06 / \mathrm{clf}$ level of theory) and 21.4 $\mathrm{kcal} / \mathrm{mol}(6-31 \mathrm{~g}(\mathrm{~d}, \mathrm{p}) / \omega \mathrm{B} 97 \mathrm{xD} / \mathrm{clf}$ level of theory) when each of the salicylaldehyde moiety rotates in turn. A more accurate calculation with a more extensive basis set at cc-pTZV/wB97xd/clf level of theory suggests this rotation requires $21.8 \mathrm{kcal} / \mathrm{mol}$ of energy. This energy barrier results in hindered rotation, preventing an easy rotation around the salicyl-anthracene bond at room temperature. This effect is more pronounced in macrocycle $\mathbf{1}$ than 2, where formation of the "saddle point" transition state is more hindered. Thus, conformers of 1 cannot interconvert, even at high temperatures.

The simultaneous rotation of the two salicyl units occurs at higher energy (ca. $40 \mathrm{kcal} / \mathrm{mol}$ ). Moreover, the structures turn out being second-order saddle points showing each two negative eigenvalues of the Hessian matrix for the simultaneous motion of the salicyl aldehydes units (Figure S79A-B). This suggests that the molecule cannot retain the $C_{2}$ or $C_{i}$ symmetry while performing the torsions and that the two salicyl groups cannot rotate at the same time.

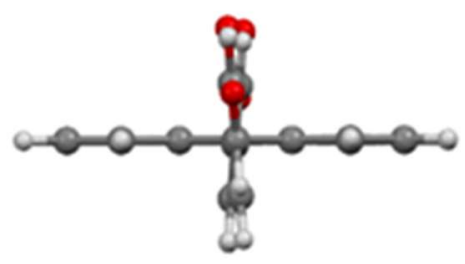

Figure S77. Minimum energy conformation for 2. Another minimum is found when the two phenol functionalities are on opposite sides relative to the anthracene fragment's average plane. 


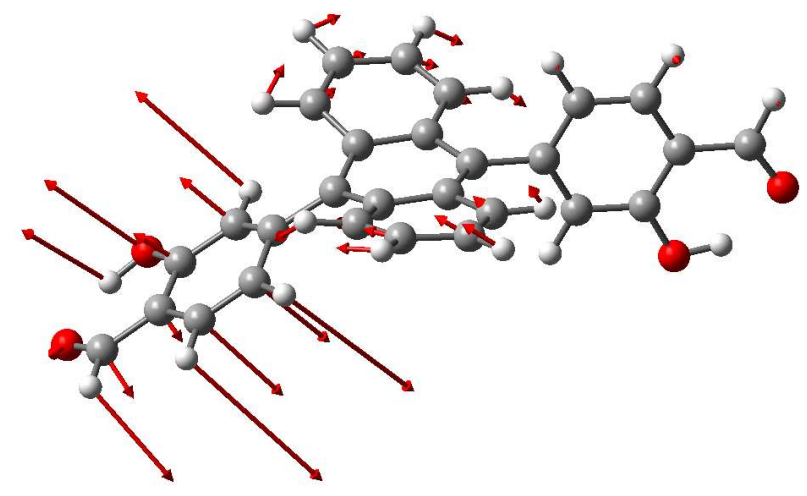

Figure S78. Transition vector $(\mathrm{x} 10)$ associated to the imaginary frequency $32.95 \mathrm{i}$ of the first-order saddle point (true TS) of 2 computed at the cc-pTZV/wB97xd/clf level of theory. The second (on the right) salicylaldehyde unit is perpendicular to the average plane of the inner anthracene ring.

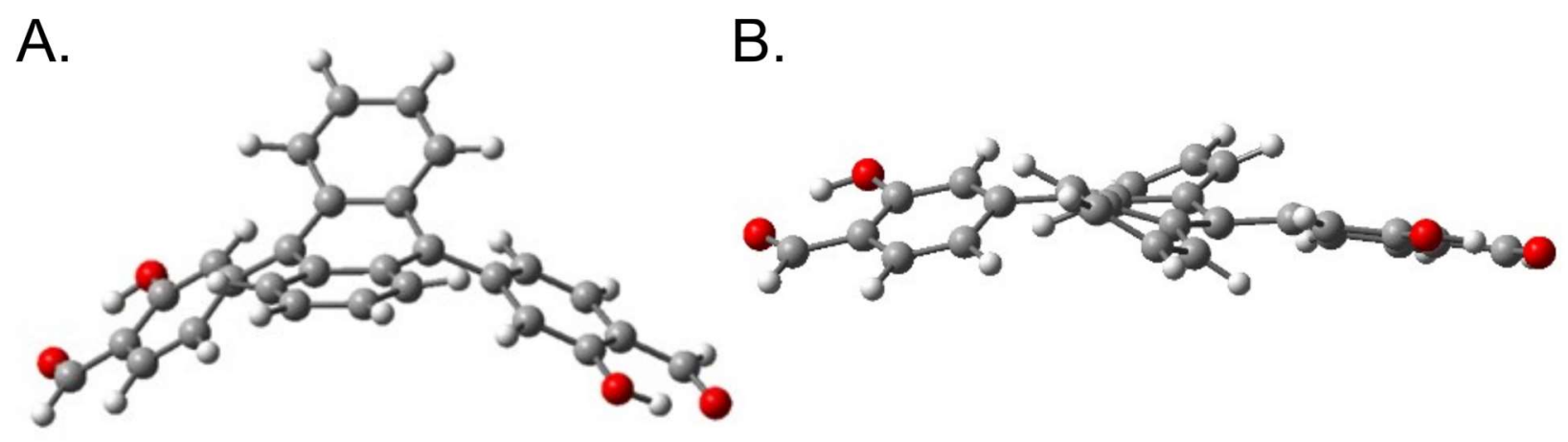

Figure S79.Computed structures for the rotation of 2. A) twisted double chair $\left(C_{2}\right.$ symmetry). B) helical $\left(C_{i}\right.$ symmetry). Second-order saddle point geometries for the simultaneous rotation of the two salicylaldehyde moieties. 


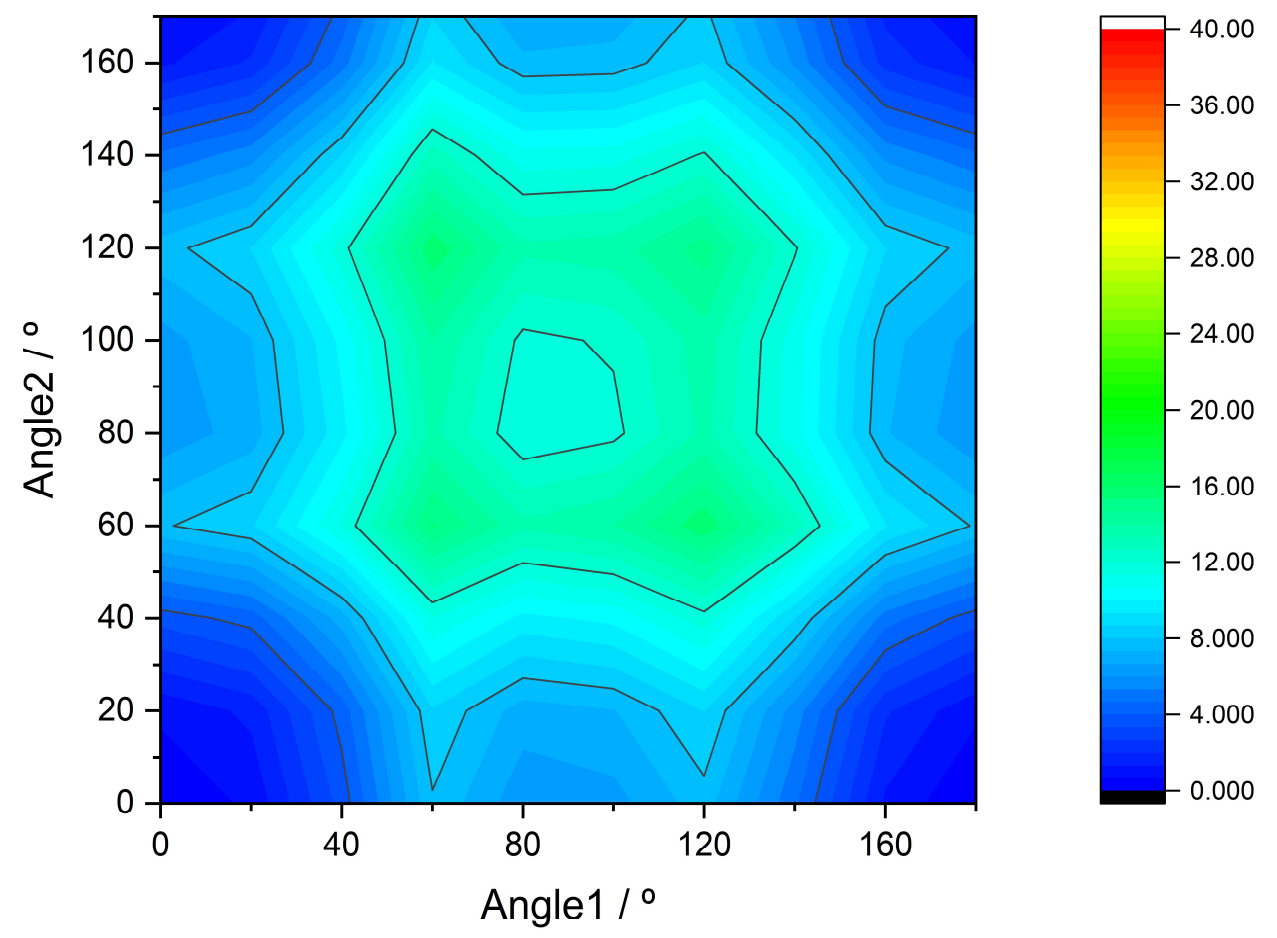

Figure S80. The trend of molecular energy $(\mathrm{kcal} / \mathrm{mol})$ of the torsion energy around (C4-C5) and (C4'-C6) bonds (x-axis and $y$-axis of the plot, respectively) computed with a step size of 10 deg in case of $2 \cdot \mathrm{O}_{2}$. The deepest energy minima are when the plane of the two salicyl rings are coplanar with the C5-O-O-C5' average plane (Figure S67).

The endoperoxo derivative $\mathbf{2} \cdot \mathrm{O}_{2}$ though lacking the planarity of the anthracene moiety compared to 2 has comparable symmetry. The SCXRD data for $2 \cdot \mathrm{O}_{2}$ illustrate this, with the salicyl groups in the anti-conformation.

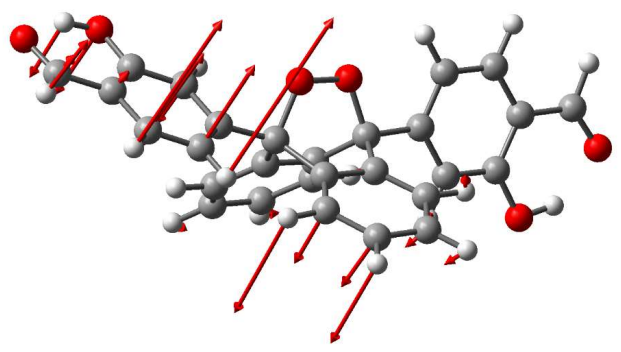

Figure S81. Transition vector (x10) associated to the imaginary frequency $68.74 \mathrm{i}$ of the first-order saddle point (true TS) of $2 \cdot \mathrm{O}_{2}$ computed at the $6-31 \mathrm{~g}(\mathrm{~d}, \mathrm{p}) / \mathrm{wB} 97 \mathrm{xd} / \mathrm{clf}$ level of theory. The second (on the right) salicylaldehyde unit plane is coplanar with the C5-O-O-C6 average plane.

There are also further minima at higher energy $(6.1 \mathrm{kcal} / \mathrm{mol})$ when each salicylaldehyde ring is perpendicular to the peroxo bridge. They are separated by TS's whose energies are $7.9 \mathrm{kcal} / \mathrm{mol}$ above the global minimum and are the TS's for the syn-anti transformation of the salicylaldehyde, which is significantly lower than in the case of $\mathbf{2}$ for the same process. The origin of the lower activation energy of the dioxo 
derivative compared to the 9,10-disalicylanthracene is related to the lower stability of the minimum energy conformation because of the " $\mathrm{sp}^{3}$ " hybridization of the 9- and 10-carbon atoms. This effect is further enhanced in the TS of $\mathbf{2} \cdot \mathrm{O}_{2}$, where the molecule has "sp" hybridized $\mathrm{C} 9$ and $\mathrm{C} 10$ atoms. In contrast, compound 2 requires atoms $\mathrm{C} 9$ and $\mathrm{C} 10$ to be excited from "sp" to "sp ${ }^{3 "}$ hybridization in the TS to allow for rotation.

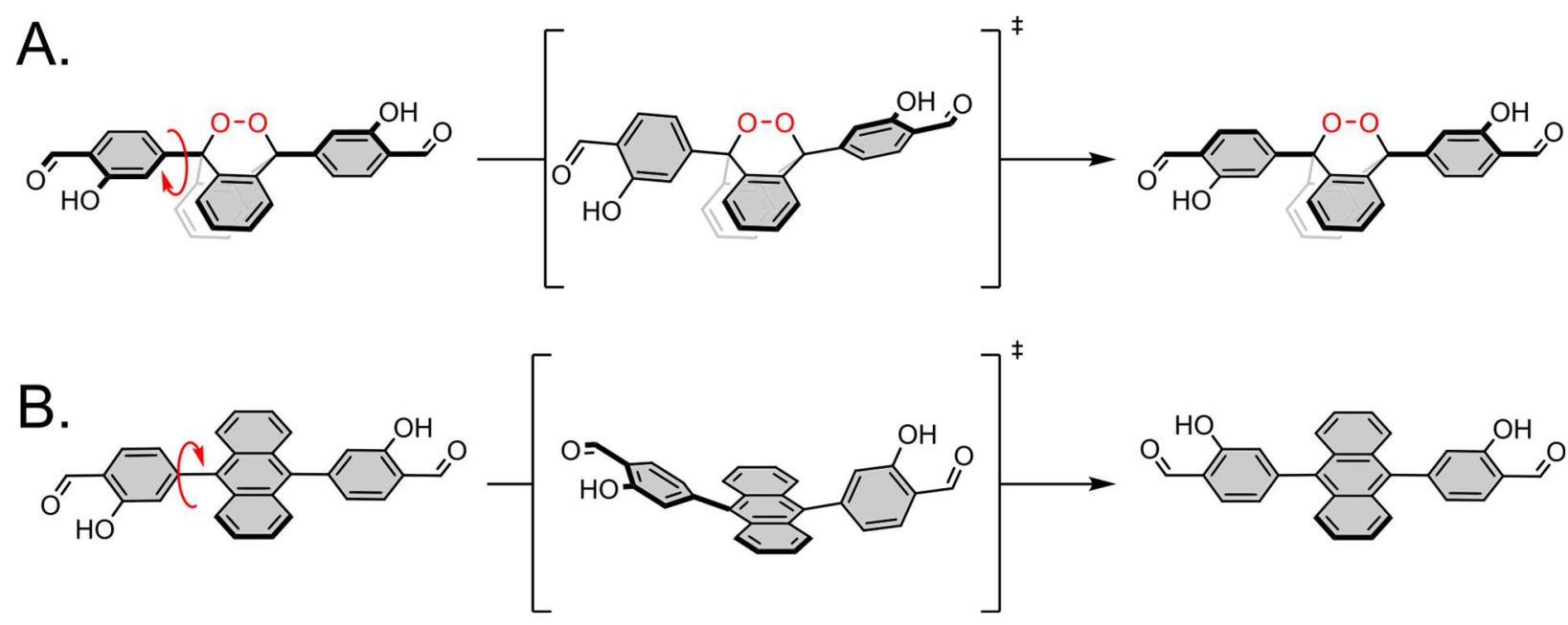

Figure S82. Rotation around A) the salicylaldehyde-endoperoxide bond $\left(2 \cdot \mathrm{O}_{2}\right)$, which goes through a less distorted transition state. Rotation around B) the salicylaldehyde-anthracene bond (2), which goes through a nonplanar transition state 


\section{Supplementary discussion on conformers of $\mathbf{1}$ and $\mathbf{4}$}

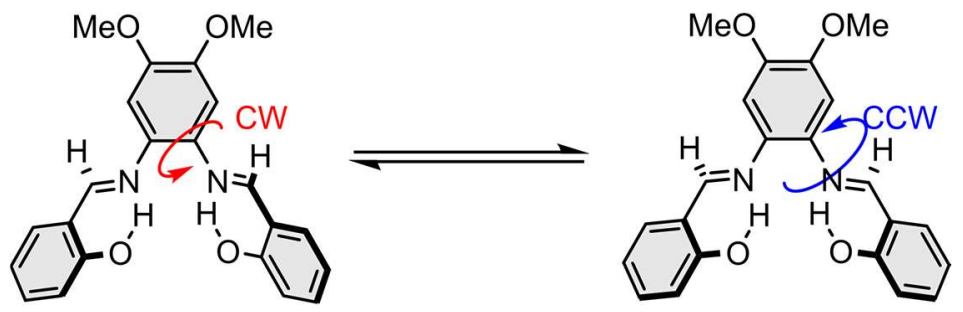

Figure S83. Twisting/rotation of the salphen moiety, resulting in (anti) and (syn) isomers.

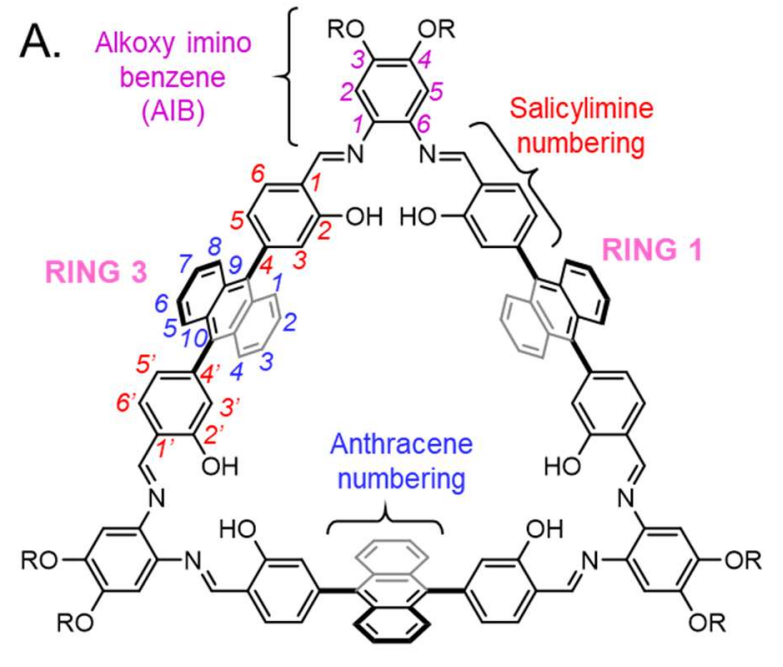

RING 2

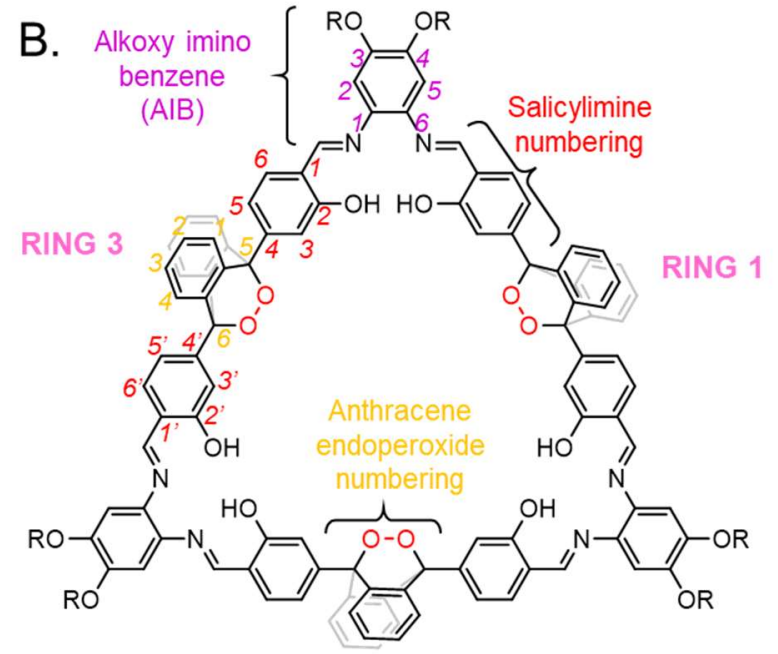

RING 2

Figure S84. The computational numbering scheme (carbon atoms) for A) 1 and B) 4 . Ring 1/2/3 refer to the anthracene or endoperoxide groups. Alkoxyimino benzene $=$ AlB .

The computations and discussion for macrocycle $\mathbf{1}$ are much more complicated than for bisaldehyde $\mathbf{2}$, owing to the rotation of one arene affecting several other groups (not just directly bonded moieties), restricted conformations, and the presence of the alkoxy imino benzene (AIB) moieties. The discussion is beyond the scope of this paper, but we provide some preliminary information here. 
A.

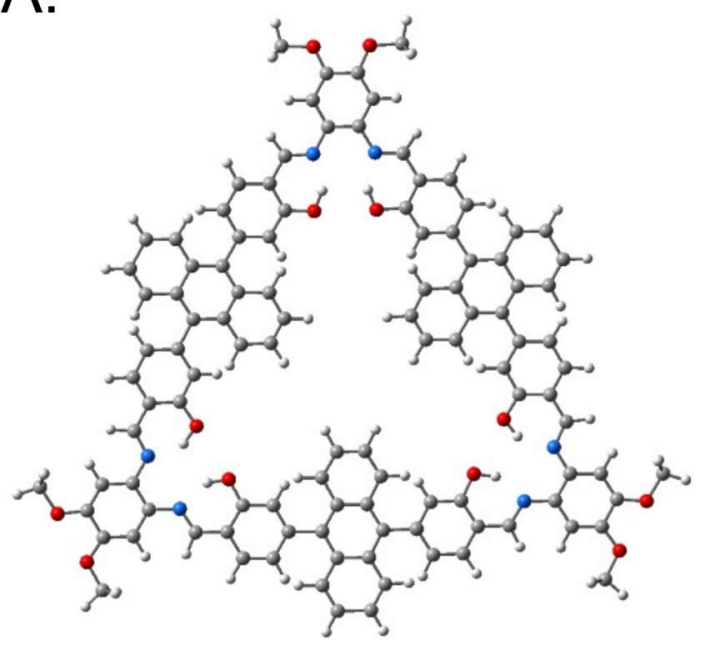

B.

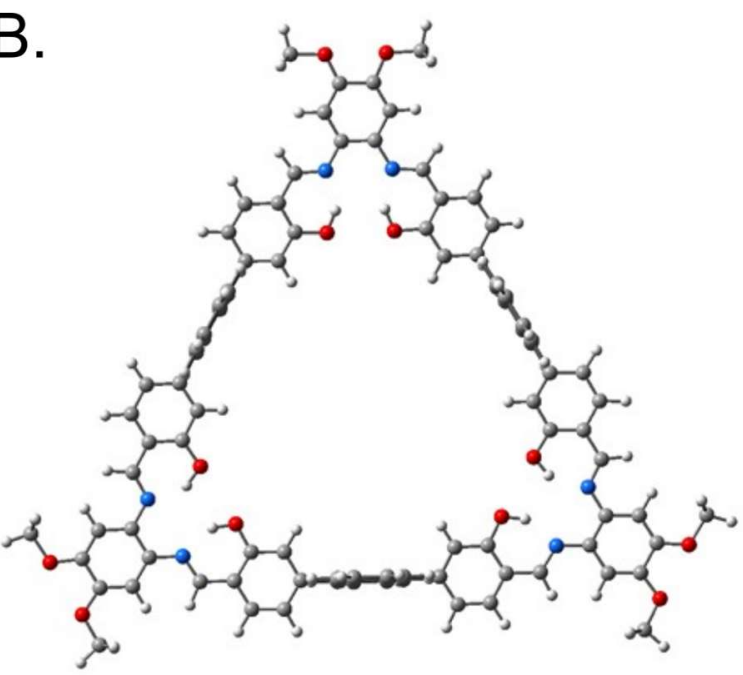

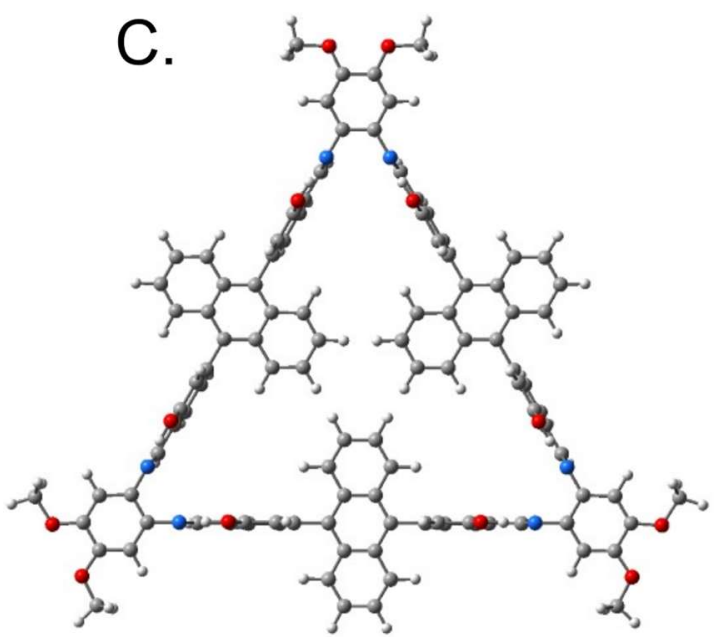

Figure S85. Highly symmetric conformations for macrocycle 1 that are not minima. A) $D_{3 \mathrm{~h}}$ (flat/planar), B) $D_{3 \mathrm{~h}}$ (perpendicular), and C) $C_{3 \mathrm{v}}$.

Macrocycle 1 cannot exist in the $D_{3 h}$ (flat/planar) conformation shown above in Figure S85A. This restriction is due to strong repulsion between the salicyl (protons on 3,5 and 3',5' positions) and anthracene moieties (protons on 2,4,5, and 8 positions). The alternative $D_{3 \mathrm{~h}}$ (anthracenes oriented perpendicular, Figure S85B) conformation, although intuitive, is not on a minimum energy surface. In this case there is the strong repulsion of the two adjacent $\mathrm{OH}$ functionalities. Among the different possible orientations of the anthracene and AIB moieties, the anthracene flip/rotation around the 9,10 bonds requires a significant amount of energy. Rotation of the anthracene while maintaining the respective positions of the AIB group is drastically higher in energy at ca. $40 \mathrm{kcal} / \mathrm{mol}$, this does not affect the overall geometry of the conformer. However, if the salicylimine group rotate in sequence along with the anthracene groups this energy is lowered to ca. 21 $\mathrm{kcal} / \mathrm{mol}$.

While twisting the AIB moiety around the same bonds requires minor geometrical change and lower energy with significant symmetry modifications engendering conformers belonging to different point group (PG) symmetries. 


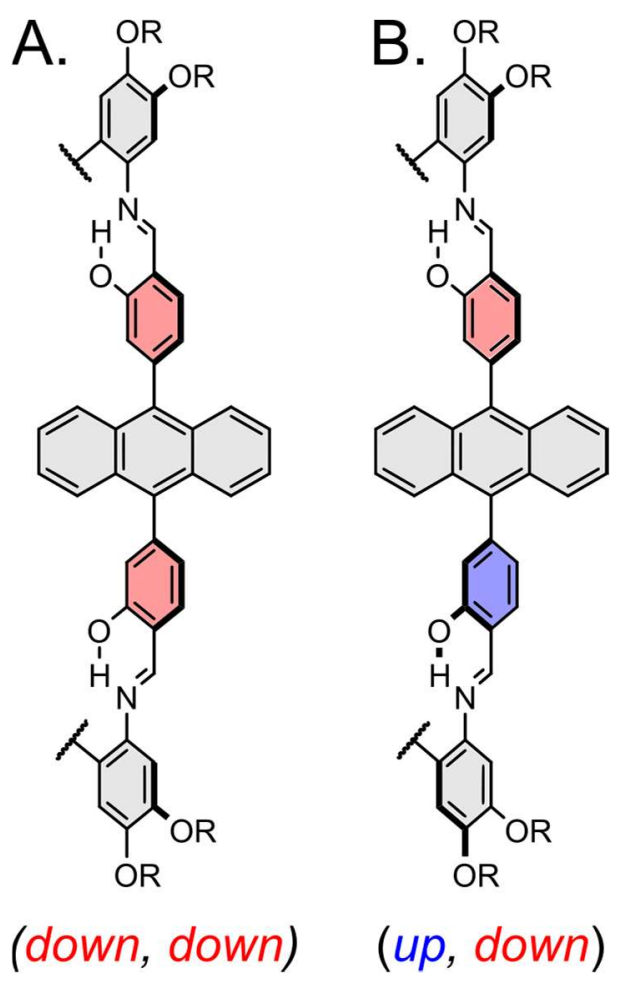

Figure S86. Possible conformations of the salicyl imine groups in $\mathbf{1 .}$

The rotation/twisting on the AIB salphen moiety is shown above in Figure S83. Twisting around this bond is very common in salphen moieties, as we can see in the solid-state structure of $\mathbf{6}$ (Scheme 2 in the main text). This repulsion occurs due to $0 \cdots O$ repulsion, leading to one salicylimine group twisting ca. $20-50^{\circ}$. Thus, the hydroxyl moieties can face the same (syn) or opposite (anti) direction (Figure S83). In case of the $C_{3 v}$ conformation the three anthracene moieties lie in a plane parallel to the one containing the AIB ones, (Figure $\mathrm{S} 85 \mathrm{C}$ ), and are subject to the repulsion among theirs $\mathrm{H} 2-\mathrm{H} 3$ or $\mathrm{H} 6-\mathrm{H} 7$ groups and is not a minimum and collapses to conformation $\mathrm{H}$ (see Table S2).

In salphen macrocycles, the $\mathrm{OH} \cdots \mathrm{N}=\mathrm{CR}$ hydrogen bond must be preserved because of the high energetic cost of breaking this bond. This pseudo six-membered ring further restricts the possible conformations of 1. The salphen $\left(\mathrm{N}_{2} \mathrm{O}_{2}\right)$ groups' conformational energy landscape near minima is very shallow (Figure S76); this allows for a $+/-20^{\circ}$ conformational shift compared to the orthogonal anthracene group. This rotation is caused by the repulsion of the salicyl imine and anthracene moieties, which prefer to be orthogonal. This repulsion allows the anthracene and two salicylimine groups to assume two major conformations: two AIB moieties are planar and orthogonal to the anthracene (Figure S86A), or the two AIB moieties have planes which are ca. $40^{\circ}$ different (Figure S86B). We dub these conformations $p$ (planar) or $o$ (orthogonal). Aside from these restrictions, the central salicylimine and anthracene groups also have restricted rotation. The salicylimine groups can either be planar, above or below the plane (Figure S86).

Thus, both the salicylimine groups and anthracene groups influence the overall conformation of the macrocycle, as seen in Figure S86 and Figure S83. Some examples of computed conformations are shown in Figure S87. This is certainly not an exhaustive list, but instead shows some representative conformations of 1. The most unstable structure (with all hydroxyl protons having intramolecular hydrogen bonds) was for the $D_{3}$ symmetric conformer (Figure S87, Conformer $\mathbf{J}$ ).

These restrictions result in 64 possible conformations of 1 where the salphen moieties point towards each other within the cavity (although many of these conformers are topologically equivalent). However, only certain symmetry operations are possible within $1\left(C_{3}, C_{2}\right.$, and $\left.\sigma_{v}\right)$ for the salicylimine and anthracene motifs, 
which reduces the number of unique conformations. Considering the cyclic topology and because the "up" and "down" labels compared to the average macrocycle plane are arbitrary, or the plane represents a mirror plane, the total number can be halved (32).

Several other structures can be removed, because of improper symmetry $\left(C_{2}\right)$, being enantiomers of each other, or are identical once a symmetry operation is applied. This, along with high energy conformation lacking even only one six-member $\mathrm{H}$-bond ring (conformation $\mathbf{A}-(\mathrm{HB})$ and $\mathrm{I}-(\mathrm{HB})$ ), yields 10 unique possibilities for 1 . They have been computed at the $6-31 \mathrm{~g}(\mathrm{~d}, \mathrm{p}) / \omega \mathrm{B} 97 \mathrm{XD} / \mathrm{chloroform}$ level of theory, and the results are reported below. 
Table S2. Energies of several conformers of 1 completed at the 6-31(d,p)/wB97XD/chloroform level of theory.

\begin{tabular}{|c|c|c|c|c|}
\hline Conformer & PG symmetry & Energy (h) & $\Delta E(h)$ & $\mathrm{kcal} / \mathrm{mol}$ \\
\hline A & $C_{s}$ & -5392.08957600 & 0.00000000 & 0.00 \\
\hline$A-(H B)^{a}$ & & -5392.07376400 & 0.01581200 & 9.92 \\
\hline B & $C_{s}$ & -5392.086134 & 0.00145760 & 0.91 \\
\hline C & $C_{s}$ & & & Converged to $\mathbf{G}$ \\
\hline D & $C_{2}$ & -5392.08818227 & 0.00139373 & 0.87 \\
\hline$E$ & $C_{2}$ & -5392.08879520 & 0.00078080 & 0.49 \\
\hline $\mathbf{F}$ & $C_{2}$ & & & Converged to $\mathrm{H}$ \\
\hline G & nosym $C_{1}$ & -5392.08798750 & 0.00158850 & 1.00 \\
\hline H & nosym $C_{1}$ & -5392.08698277 & 0.00259323 & 1.63 \\
\hline I & $C_{3 v}$ & -5392.08848086 & 0.00109514 & 0.69 \\
\hline $\mathrm{I}-(\mathrm{HB})^{a}$ & & -5392.07260465 & 0.01697135 & 10.65 \\
\hline J & $D_{3}$ & -5392.08568290 & 0.00389310 & 2.44 \\
\hline
\end{tabular}

aThese conformations are the same as their parent structures but lack one $(\mathrm{C}=\mathrm{N} \cdots \mathrm{H}-\mathrm{O})$ hydrogen-bond in the macrocycle.

Conformers $\mathbf{A}$ and I seem to be possible candidates to explain the ${ }^{1} \mathrm{H}$ NMR spectra we obtain for macrocycle 1. We see two sets of signals that have three-fold and two-fold symmetry, respectively. The calculated $C_{3}$ and $C_{s}$ symmetric structures fulfil these two requirements. Also, the structures are very close in energy (less than $1 \mathrm{kcal} / \mathrm{mol}$ apart), which supports why both structures are detected in almost equal mol ratios (via integration of the corresponding ${ }^{1} \mathrm{H}$ NMR spectrum). 


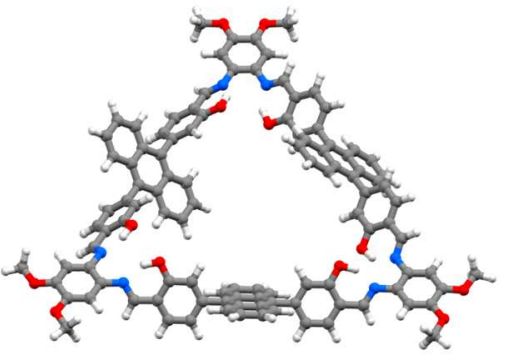

Conformer - A

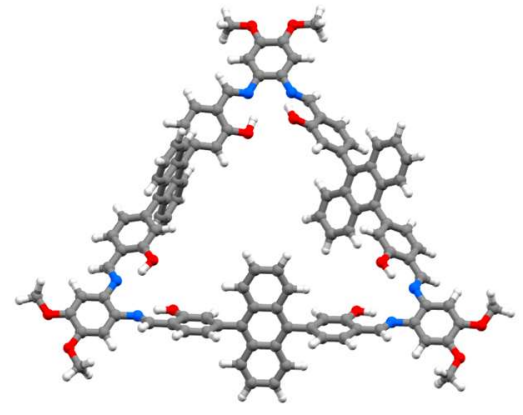

Conformer - E

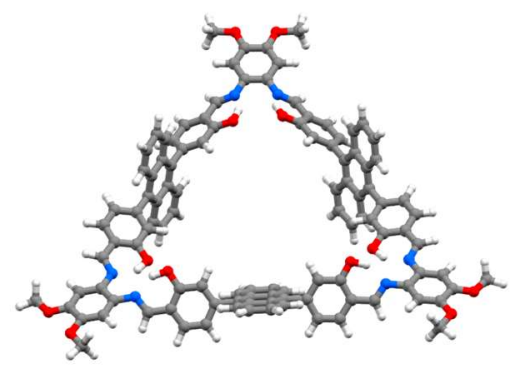

Conformer - B

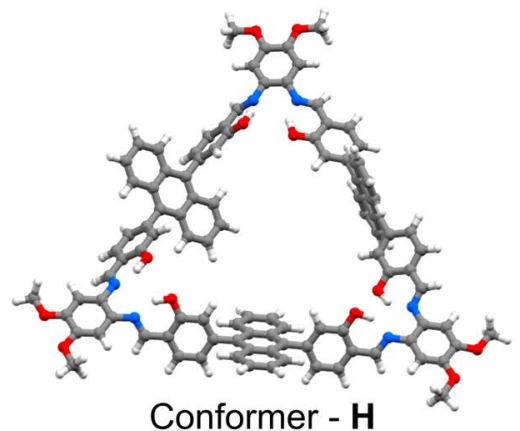

Conformer - $\mathbf{H}$

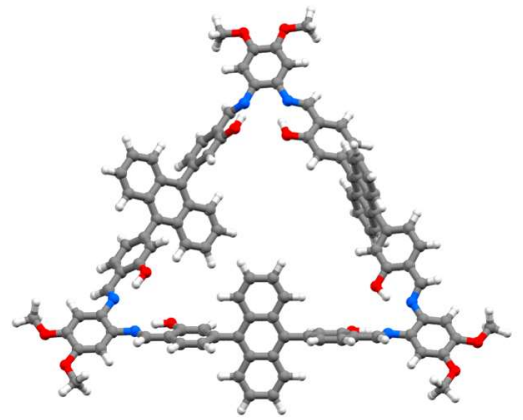

Conformer - D

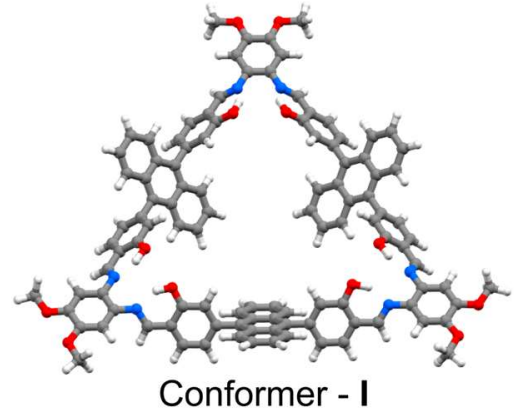

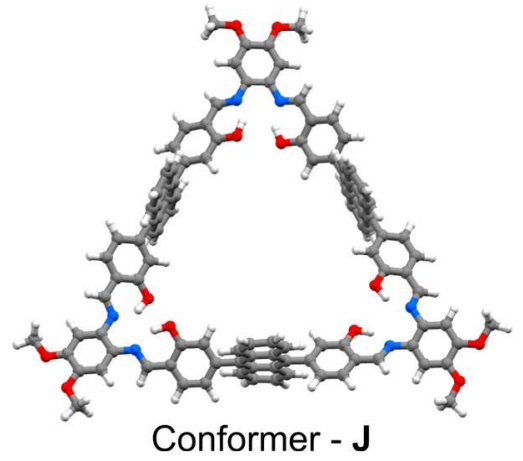

Figure S87. Several representative conformations of macrocycle 1 calculated at the $\omega B 97 \times D / 6-$ $31 \mathrm{~g}(\mathrm{~d}, \mathrm{p}) /$ chloroform level of theory.

The dynamics of macrocycle 4 are much simpler than for 1 . We only observe one set of signals in the ${ }^{1} \mathrm{H}$ NMR spectrum for this compound regardless of solvent used. Thus, the many conformations of 4 must be able to interconvert easily at room temperature. We calculated several structures for 4 with various symmetries at the $\omega \mathrm{B} 97 \times \mathrm{D} / 6-31 \mathrm{~g}(\mathrm{~d}, \mathrm{p}) / \mathrm{vac}$ level of theory. Again, the $D_{3 \mathrm{~h}}$ structure for 4 was not a minimum (ca. $7.35 \mathrm{kcal} / \mathrm{mol}$ ) on the potential energy surface. The lowest energy was seen for a $C_{\mathrm{s}}$ point group (Figure S88), though a $C_{2}$ symmetric compound is close in energy (difference of ca. $1.5 \mathrm{kcal} / \mathrm{mol}$ ). However, these structures can easily interconvert due to minimal distortion in the transition state (Figure S79). 


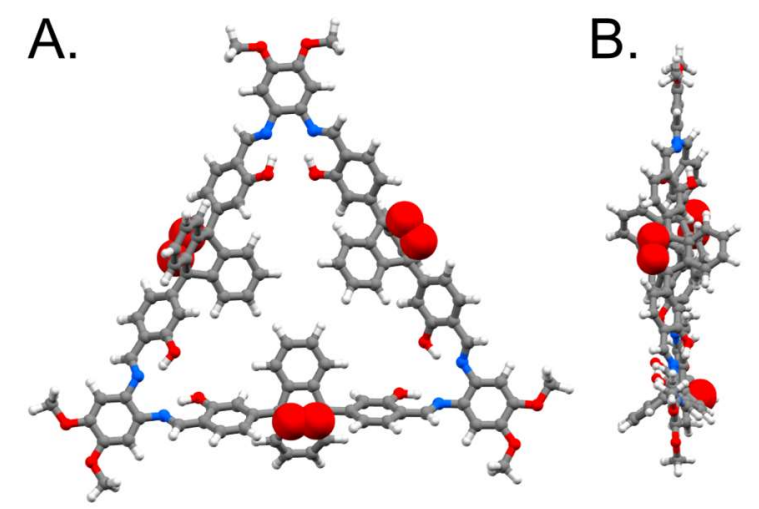

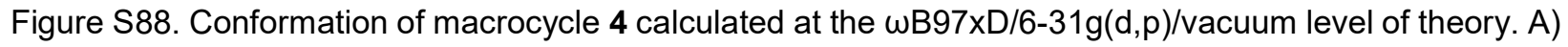
top view. B) side-view. 


\section{Cartesian coordinates of the discussed structures}

\author{
Bisaldehyde 2 / $\omega b 97 X D$
}

6-31gdp/ $\omega b 97 X \mathrm{D} / \mathrm{CHCl} 3$.

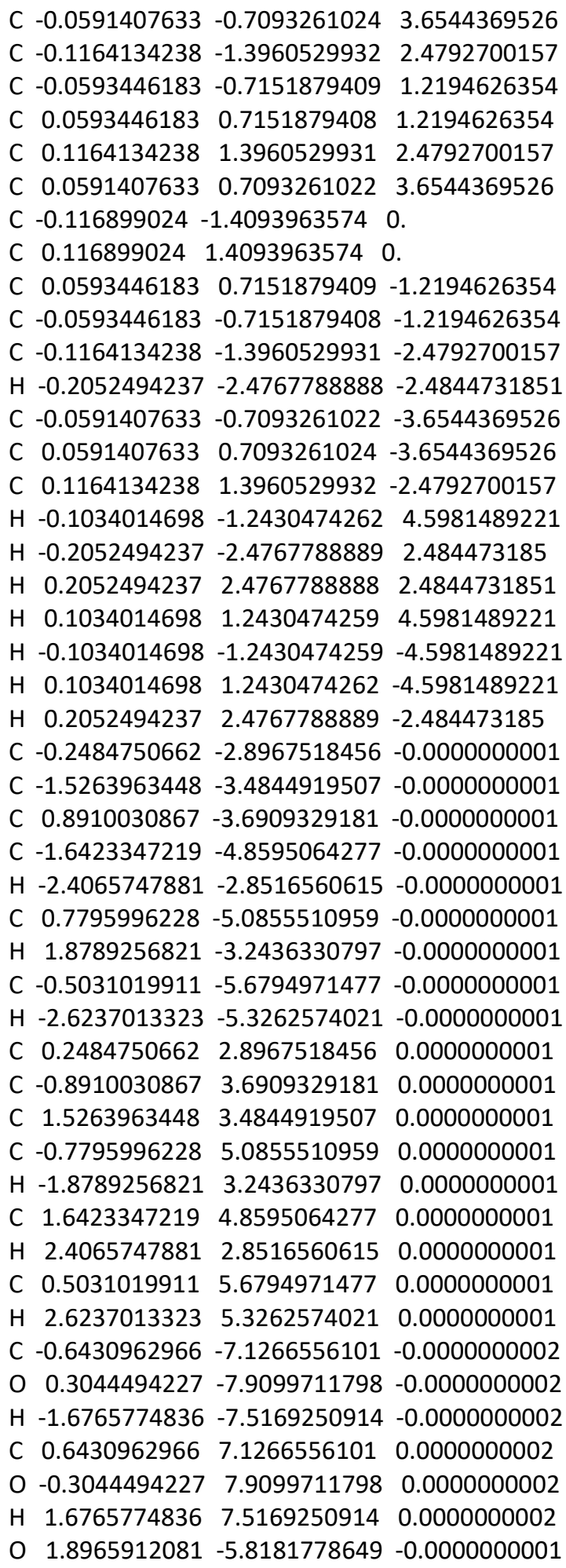

H $1.6252243217-6.7623845306-0.0000000002$ $\begin{array}{lllll}\text { O } & -1.8965912081 & 5.8181778649 & 0.0000000001\end{array}$ H $-1.6252243217 \quad 6.7623845306 \quad 0.0000000002$

Butterfly-like TS for Bisaldehyde 2 $\omega \mathrm{b} 97 \mathrm{XD}$

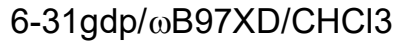

C $-0.5592665215-3.4408529248 \quad 1.394486422$

C -1.2539026176 -2.35280929510 .960593352$

C $-0.6244739436-1.07338013490 .8209641896$

C $0.7971676572-0.968328278 \quad 1.0089231947$

C $1.4585530021-2.1175688706 \quad 1.5530578887$

C $0.8077458286-3.3011835785 \quad 1.7493328092$

C -1.37560960190 .07176642390 .516539966$

C $1.4593744904 \quad 0.2636786835 \quad 0.7307005882$

C $0.6506191791 \quad 1.4358232093 \quad 0.8097776207$

C $-0.7710042479 \quad 1.3338499872 \quad 0.6197609591$

C $-1.55618294332 .5307464506 \quad 0.5640610618$

H -2.6174272251 2.44297329790 .3601428355

C $-1.0063773155 \quad 3.751862588 \quad 0.8119520467$

C $0.3638004966 \quad 3.8402422047 \quad 1.1701085206$

C $1.1579124394 \quad 2.729900874 \quad 1.1595623192$

H -1.0569623649 -4.39686779961 .5166355047$

H $-2.3145633678-2.43264681440 .7507842742$

H $2.4778942279-2.01974299991 .9024299129$

H $1.3340428612-4.1337844235 \quad 2.2043464566$

H $-1.6207753913 \quad 4.6454894952 \quad 0.7893389924$

H $0.7776716595 \quad 4.7928132645 \quad 1.4843974168$

H $2.1748512018 \quad 2.8153464266 \quad 1.5183307107$

C - $-2.8261687207-0.04070056910 .1870136929$

C $-3.7803849868-0.0967254614 \quad 1.219669586$

C $-3.2233723113-0.0829565216-1.1426384549$

C $-5.1194932783-0.1957252906 \quad 0.9018046101$

H $-3.4541110261-0.06117527732 .2528753815$

C $-4.5801085347-0.1831877888-1.4701620541$

H $-2.4927972361-0.0384275746-1.9427644888$

C $-5.5417322774-0.2405316013-0.4359398588$

H $-5.8670956639-0.23925930541 .6893386879$

C $2.8663674645 \quad 0.30375591350 .2165491604$

C $3.5792332082-0.8741685669-0.0531146004$

C $3.47724265331 .5140131693-0.2121642384$

C $4.8675923419-0.8649570042-0.5885916696$

H $3.1526889949-1.85279702740 .0971932035$

C $4.7464130251 \quad 1.5308866348-0.7454397976$

H $2.9426859522 .4481942376-0.1829027443$

C $5.4875094550 .3550145079-0.9222545076$

H $5.18050869342 .4773548261-1.0568411808$

C -6.9570291121 $-0.3442691575-0.7537507424$

O $-7.4033086477-0.3883428207-1.8982095233$

H $-7.6487659079-0.3837898673 \quad 0.1065244354$

C $6.82218178940 .3843409993-1.4894723235$ 
O $7.5003206413-0.6197647038-1.7036015002$

H $7.2272107104 \quad 1.3824065562-1.7352796952$

O $-4.9268891172-0.2214261464-2.7591280305$

H $-5.9061284292-0.2917608876-2.7954953013$

O $5.4753230312-2.0420034046-0.7838945378$

H $6.3582123753-1.8503806341-1.1675068906$

\section{Bisaldehyde 2 M06}

6-31gdp/m06/CHCl3

C $0.7096079628 \quad 3.6524042569 \quad-0.1758202286$

C $1.39908066642 .4747606905 \quad-0.1743997481$

C $0.7190967863 \quad 1.2196138313-0.1718466723$

C $-0.7190967863 \quad 1.2196138313-0.1718466723$

C $-1.39908066642 .4747606905-0.1743997481$

C $-0.7096079628 \quad 3.6524042569-0.1758202286$

C 1.415476506 0. -0.175523762

C -1.415476506 0. -0.175523762

C $-0.7190967863-1.2196138313-0.1718466723$

C $0.7190967863-1.2196138313-0.1718466723$

C $1.3990806664-2.4747606905-0.1743997481$

H $2.4865361751-2.4792987405-0.1725229373$

C $0.7096079628-3.6524042569-0.1758202286$

C $-0.7096079628-3.6524042569-0.1758202286$

C $-1.3990806664-2.4747606905-0.1743997481$

H $1.2472553706 \quad 4.5972313434-0.1760724006$

H $2.48653617512 .4792987405-0.1725229373$

H -2.4865361751 $2.4792987405-0.1725229373$

H -1.2472553706 $4.5972313434-0.1760724006$

H $1.2472553706-4.5972313434-0.1760724006$

H -1.2472553706 -4.5972313434 -0.1760724006

H -2.4865361751 -2.4792987405 -0.1725229373

C 2.9022575904 0. -0.2130748345

C 3.5609010908 0. -1.4556042302

C 3.6312230483 0. 0.9695316825

C 4.9394602044 0. -1.4929766864

H 2.9736248254 0. -2.370474097

C 5.0284644615 0. 0.9379119298

H 3.1281690409 0. 1.9340286327

C 5.6938770768 0. -0.3101038455

H 5.4680654096 0. -2.4455099976

C -2.9022575904 0. -0.2130748345

C -3.6312230483 o. 0.9695316825

C -3.5609010908 0. -1.4556042302

C -5.0284644615 0. 0.9379119298

H -3.1281690409 0. 1.9340286327

C -4.9394602044 0. -1.4929766864

H -2.9736248254 0. -2.370474097

C -5.6938770768 0. -0.3101038455

H -5.4680654096 0. -2.4455099976

C 7.1401969786 0. -0.3737135821

o 7.8809383748 o. 0.6068867991
H 7.5717835271 0. -1.3969456963

C -7.1401969786 0. -0.3737135821

O -7.8809383748 O. 0.6068867991

H -7.5717835271 0. -1.3969456963

O 5.6937651793 0. 2.0937268113

H 6.6552355094 0. 1.8823067908

O -5.6937651793 0. 2.0937268113

H -6.6552355094 0. 1.8823067908

\section{Butterfly-like TS Bisaldehyde 2 M06 $6-31 \mathrm{gdp} / \mathrm{m06} / \mathrm{CHCl} 3$}

C $-0.5592665215-3.4408529248 \quad 1.394486422$

C $-1.2539026176-2.35280929510 .960593352$

C $-0.6244739436-1.07338013490 .8209641896$

C $0.7971676572 \quad-0.968328278 \quad 1.0089231947$

C $1.4585530021-2.1175688706 \quad 1.5530578887$

C $0.8077458286-3.3011835785 \quad 1.7493328092$

C $-1.3756096019 \quad 0.07176642390 .516539966$

C $1.4593744904 \quad 0.26367868350 .7307005882$

C $0.6506191791 \quad 1.4358232093 \quad 0.8097776207$

C $-0.7710042479 \quad 1.3338499872 \quad 0.6197609591$

C $-1.5561829433 \quad 2.5307464506 \quad 0.5640610618$

H -2.6174272251 2.44297329790 .3601428355

C $-1.0063773155 \quad 3.751862588 \quad 0.8119520467$

C $0.3638004966 \quad 3.8402422047 \quad 1.1701085206$

C $1.1579124394 \quad 2.729900874 \quad 1.1595623192$

H -1.0569623649 $-4.3968677996 \quad 1.5166355047$

H $-2.3145633678-2.43264681440 .7507842742$

H $2.4778942279-2.01974299991 .9024299129$

H $1.3340428612-4.13378442352 .2043464566$

H $-1.6207753913 \quad 4.6454894952 \quad 0.7893389924$

H $0.7776716595 \quad 4.7928132645 \quad 1.4843974168$

H $2.1748512018 \quad 2.8153464266 \quad 1.5183307107$

C - $2.8261687207-0.04070056910 .1870136929$

C $-3.7803849868-0.0967254614 \quad 1.219669586$

C $-3.2233723113-0.0829565216-1.1426384549$

C $-5.1194932783-0.1957252906 \quad 0.9018046101$

H $-3.4541110261-0.06117527732 .2528753815$

C $-4.5801085347-0.1831877888-1.4701620541$

H $-2.4927972361-0.0384275746-1.9427644888$

C $-5.5417322774-0.2405316013-0.4359398588$

H $-5.8670956639-0.23925930541 .6893386879$

C $2.8663674645 \quad 0.30375591350 .2165491604$

C $3.5792332082-0.8741685669-0.0531146004$

C $3.47724265331 .5140131693-0.2121642384$

C $4.8675923419-0.8649570042-0.5885916696$

H $3.1526889949-1.85279702740 .0971932035$

C $4.7464130251 \quad 1.5308866348-0.7454397976$

H $2.9426859522 .4481942376-0.1829027443$

C $5.4875094550 .3550145079-0.9222545076$

H $5.18050869342 .4773548261-1.0568411808$

C $-6.9570291121-0.3442691575-0.7537507424$ 
O $-7.4033086477 \quad-0.3883428207-1.8982095233$

H $-7.6487659079-0.38378986730 .1065244354$

C $6.82218178940 .3843409993-1.4894723235$

O $7.5003206413-0.6197647038-1.7036015002$

H $7.2272107104 \quad 1.3824065562-1.7352796952$

O $-4.9268891172-0.2214261464-2.7591280305$

H $-5.9061284292-0.2917608876-2.7954953013$

O $5.4753230312-2.0420034046-0.7838945378$

H $6.3582123753-1.8503806341-1.1675068906$

\section{Bisaldehyde 2 cc-pVTZ}

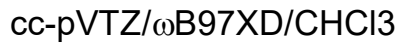

$\begin{array}{llll}\text { C } & 0.7075498921 & 3.6410516161 & 0.0607407632\end{array}$

C $1.390715952 \quad 2.4708752852 \quad 0.1176780421$

C $0.7129118619 \quad 1.2140268077 \quad 0.0598663545$

C $-0.712582013 \quad 1.2142605787-0.0590398339$

C $-1.390044492 .4713318773-0.115999466$

C $-0.7065604793 \quad 3.6412838833-0.0582701446$

C $1.4048395235-0.000230576 \quad 0.116852144$

C $-1.40483952350 .000230576-0.116852144$

C $-0.7129118619-1.2140268077-0.0598663545$

C $0.712582013-1.2142605787 \quad 0.0590398339$

C $1.39004449-2.47133187730 .115999466$

H $2.4669654388-2.4798024572 \quad 0.205631243$

$\begin{array}{llll}\text { C } & 0.7065604793 & -3.6412838833 & 0.0582701446\end{array}$

C $-0.7075498921-3.6410516161-0.0607407632$

C $-1.390715952-2.4708752852-0.1176780421$

H $1.2394329055 \quad 4.581447367 \quad 0.1057607557$

H $2.46763911172 .4789916002 \quad 0.2073155823$

H - $2.46696543882 .4798024572-0.205631243$

H - $-1.2381887488 \quad 4.5818541034-0.102653649$

H $1.2381887488-4.58185410340 .102653649$

H - $-1.2394329055-4.581447367-0.1057607557$

H $-2.4676391117-2.4789916002-0.2073155823$

$\begin{array}{llll}\text { C } 2.8885469233 & -0.000476574 & 0.2477038682\end{array}$

C $3.4748958393-0.00096469151 .5191393337$

C $3.6795794497-0.0002211186-0.8870439584$

C $4.8448343071-0.00118894941 .6334150011$

H $2.8461644429-0.00115900612 .3977804007$

C $5.0682036858-0.0004478176-0.7774072416$

H $3.23254828830 .0001568441-1.8714102037$

C $5.6616624764-0.00093845460 .4989844712$

H $5.3105922189-0.00156711212 .6111753648$

C $-2.88854692330 .000476574-0.2477038682$

C $-3.6795794497 \quad 0.0002211186 \quad 0.8870439584$

C $-3.4748958393 \quad 0.0009646915-1.5191393337$

$\begin{array}{llll}\text { C }-5.0682036858 & 0.0004478176 & 0.7774072416\end{array}$

H $-3.2325482883-0.0001568441 \quad 1.8714102037$

C $-4.84483430710 .0011889494-1.6334150011$

H - $2.84616444290 .0011590061-2.3977804007$

C $-5.66166247640 .0009384546-0.4989844712$
H $-5.31059221890 .0015671121-2.6111753648$

C $7.1054345376-0.00118297530 .6427005724$

$\begin{array}{llll}\text { O } & 7.8903086633 & -0.0009944375 & -0.29372567\end{array}$

H $7.4875337142-0.00156197541 .6762404173$

C -7.1054345376 $0.0011829753-0.6427005724$

$\begin{array}{llll}\text { O } & -7.8903086633 & 0.0009944375 & 0.29372567\end{array}$

H -7.4875337142 $0.0015619754-1.6762404173$

O $5.8004885009-0.0001911639-1.8923633948$

H $6.7414374775-0.0004083244-1.6235427778$

$\begin{array}{lllll}\text { O } & -5.8004885009 & 0.0001911639 & 1.8923633948\end{array}$

H -6.7414374775 $0.0004083244 \quad 1.6235427778$

Butterfly-like TS Bisaldehyde 2 cc-pVTZ cc-pVTZ / $\omega b 97 X \mathrm{D} / \mathrm{CHCl} 3$.

C $-0.5717711726-3.4301019077 \quad 1.3701950174$

C $-1.2576823417-2.34190715580 .9425289585$

$\begin{array}{llll}\text { C }-0.6247017854 & -1.0684146902 & 0.8087399974\end{array}$

$\begin{array}{llll}\text { C } & 0.791865321 & -0.9698978046 & 0.9977222135\end{array}$

C $1.4450243835-2.12222959741 .5328093378$

C $0.7914649704 \quad-3.2979565791 \quad 1.7242090275$

$\begin{array}{llll}\text { C } & -1.3702699884 & 0.0764797632 & 0.5159430337\end{array}$

$\begin{array}{llll}\text { C } & 1.4555930346 & 0.2583421589 & 0.7326871666\end{array}$

$\begin{array}{llll}\text { C } & 0.6517096863 & 1.4266170011 & 0.8222412312\end{array}$

C $-0.76492869321 .3305524261 \quad 0.6308320818$

C $-1.5432882223 \quad 2.52738966790 .5818708558$

H $-2.599743252 \quad 2.447683783 \quad 0.3698298447$

C $-0.9942490872 \quad 3.73868305320 .844154998$

C $0.37049131863 .8187505524 \quad 1.2080271002$

C $1.1588042332 \quad 2.7123085388 \quad 1.1847341547$

H -1.0718466734 -4.3811610116 1.4880395711

H -2.3149417728 -2.41762141690 .7330736399$

H $2.462100804-2.0342988678 \quad 1.8782128299$

H $1.3123331992-4.131667663 \quad 2.1745945143$

H $-1.603346594 \quad 4.63152437820 .8264186087$

H $0.7842738342 \quad 4.763190697 \quad 1.5339445282$

$\begin{array}{llll}\text { H } & 2.1730918078 & 2.793445282 & 1.539369607\end{array}$

C $-2.8171171336-0.03196553890 .1854051755$

C $-3.7739586875-0.0154804673 \quad 1.2080055313$

C $-3.2060404903-0.1474913066-1.1364881647$

C $-5.1071325238-0.11438792280 .8882002032$

H -3.45598133760 .07492764312 .2365935166$

C $-4.5560929714-0.2480671682-1.4657804517$

H -2.4716920237 -0.161132725 -1.9297281235

C $-5.5214532194-0.2310280706-0.441664606$

H $-5.8574532057-0.10272811641 .6691355831$

$\begin{array}{llll}\text { C } 2.859370051 & 0.3016985119 & 0.2203966403\end{array}$

C $3.5737972039-0.8688144771-0.0518977144$

C $3.4659158647 \quad 1.5096751362-0.2019357325$

C $4.8532868374-0.8551892683-0.5925182412$

H $3.1524106896-1.8450735220 .0993323986$

C $4.7270575706 \quad 1.5301331103-0.7403358214$

Page: S70 
H $2.93475336742 .4405462101 \quad-0.1635119686$

C $5.46674269540 .3614442898-0.9255461832$

H $5.1569364803 \quad 2.4752348476-1.0487695251$

C $-6.9345728923-0.3327280642-0.7562065155$

O $-7.3814281058-0.4378334019-1.8882844077$

H $-7.6229702765-0.3104909717 \quad 0.1038823973$

C $6.79506262880 .4017960128-1.4993158033$

O $7.4784363502-0.5875927223-1.7219416751$

H $7.1867436745 \quad 1.4030912844-1.7414970514$

O $-4.8965753014-0.3577848988-2.7503378375$

H $-5.8725983719-0.4164349932-2.7901383848$

O $5.4632172854-2.0279587751-0.7957060569$

H $6.340545422-1.8351302235-1.1814818392$

\section{Butterfly-like TS Bisaldehyde $2 \cdot \mathrm{O}_{2} \mathrm{C} 2 \mathrm{v}$}

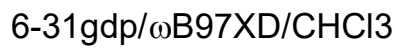
O 7.6304617888 0. 1.3997467553
O $5.2964050156 \quad 0.2 .6454490515$
H $6.2750989406 \quad 0.2 .5400282047$
O -7.6304617888 O. 1.3997467553
O -5.2964050156 0. 2.6454490515
H -6.2750989406 0. 2.5400282047
O 0.7184124626 0. 1.2700907742
O $-0.7184124626 \quad 0 . \quad 1.2700907742$
C 6.9989198376 0. 0.3461552831
H 7.5363513813 0. -0.6254905003
C 5.5532016987 0. 0.2573461812
C 4.7601110299 0. 1.425505443
C 3.3651354092 0. 1.3160865774
H $2.775749071 \quad 0.2 .2268434058$
C 2.766097971 0. 0.0671647307
C 3.5511860949 0. -1.102553501
H 3.0708695476 0. -2.0782213003
C 4.9246388204 0. -0.9969321809
H 5.5460110988 0. -1.8914257115
C 1.2689326333 0. -0.0844994281
C -1.2689326333 0. -0.0844994281
C -2.766097971 0. 0.0671647307
C -3.5511860949 0. -1.102553501
H -3.0708695476 0. -2.0782213003
C -4.9246388204 0. -0.9969321809
H -5.5460110988 0. -1.8914257115
C -5.5532016987 0. 0.2573461812
C -4.7601110299 0. 1.425505443
C -3.3651354092 0. 1.3160865774
H -2.775749071 0. 2.2268434058
C -6.9989198376 0. 0.3461552831
H -7.5363513813 0. -0.6254905003
C $0.6998938254 \quad 1.2394041623-0.7461022655$
C $1.3993237344 \quad 2.3412868587 \quad-1.215745507$
H $2.4861893875 \quad 2.3565426924-1.1925370496$

C $0.6945461728 \quad 3.4335720257 \quad-1.7194910578$

H $1.23816552924 .2928116226-2.1038719474$

C $-0.6945461728 \quad 3.4335720257-1.7194910578$

H $-1.23816552924 .2928116226-2.1038719474$

C $-1.3993237344 \quad 2.3412868587-1.215745507$

H $-2.4861893875 \quad 2.3565426924-1.1925370496$

C $-0.6998938254 \quad 1.2394041623-0.7461022655$

C $0.6998938254-1.2394041623-0.7461022655$

C $1.3993237344-2.3412868587-1.215745507$

H $2.4861893875-2.3565426924-1.1925370496$

C $0.6945461728-3.4335720257-1.7194910578$

H $1.2381655292-4.2928116226-2.1038719474$

C $-0.6945461728-3.4335720257-1.7194910578$

H $-1.2381655292-4.2928116226-2.1038719474$

C - $1.3993237344-2.3412868587-1.215745507$

H -2.4861893875 -2.3565426924 -1.1925370496

C $-0.6998938254-1.2394041623-0.7461022655$

\section{Bisaldehyde $2 \cdot \mathrm{O}_{2}$}

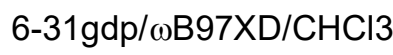

$\begin{array}{lllll}\text { O } & 0.3614722713 & 7.8308162764 & 0.2936552561\end{array}$

O $1.8220031621 \quad 5.7214428235-0.3008566601$

H $1.61100811826 .6600056237-0.1057696038$

$\begin{array}{llllll}\text { O } & 0.3147488341 & -7.6132158547 & 0.4647102998\end{array}$

O $-0.0772272413-5.7991673114-1.4000355244$

H $0.0360240617-6.6881527163-0.9985720116$

C -0.61130610497 .08312463150 .3470529837$

H - $-1.6062821533 \quad 7.4916363953 \quad 0.5976891257$

C $-0.547439379 \quad 5.64957482090 .0972638498$

C $0.6801050524 \quad 5.0325428075-0.2199608674$

C $0.71986979023 .6529884945-0.4495825982$

H $1.68680004143 .2054950687-0.6360358754$

C $-0.4409211092 \quad 2.8915517862-0.4039339529$

C $-1.65375080893 .4987897804-0.0290093236$

H $-2.54579724092 .9032446278 \quad 0.1077138145$

C $-1.6988551548 \quad 4.8576842095 \quad 0.2047953749$

H $-2.6357399435 \quad 5.3281467616 \quad 0.4898694234$

C $-0.3647406654 \quad 1.3772068345-0.5484082034$

C $-0.1533587276-1.1263158357-0.1109670741$

C $-0.0098640116-2.58322570350 .2724472185$

C $0.2162931123-2.95959913251 .6046276922$

H $0.291334958-2.2071223714 \quad 2.3773292395$

C $0.3424191673-4.2997725193 \quad 1.9159572355$

H $0.5177342935-4.6025229592 \quad 2.9447629781$

$\begin{array}{llll}\text { C } 0.2490344232 & -5.2882601765 & 0.9273815717\end{array}$

C $0.0214073996-4.9038698231-0.4129423312$

C $-0.105704984-3.5484876997-0.7249963933$

H - $0.2794434271-3.2729305201-1.7595159268$

C $0.3856604797 \quad-6.6941856053 \quad 1.2771985993$

H $0.5629839796-6.9166906655 \quad 2.3443092297$

C $-1.6110983380 .6215776079-0.9892205607$

Page: S71 
C - $-2.72069726061 .11080368-1.6644507885$

H $-2.77811891242 .1531529497-1.9553252799$

C -3.7664028346 $0.2442767232-1.9861289207$

H $-4.63262003880 .6252101514-2.5167736208$

C -3.7021261388 -1.0959303958 -1.6280302972

H $-4.5253932864-1.7622967054-1.8627053707$

C $-2.5671984863-1.5995739929-0.9907791499$

H $-2.5097743856-2.6528966016-0.7417191435$

C $-1.5101480669-0.7484648587-0.7066830669$

C $0.77241666390 .7610907831-1.3526769426$

C $1.56619583691 .354889359-2.3243841335$

H $1.4115326592 .3871598739-2.614819115$

$\begin{array}{llll}\text { C } & 2.5636568161 & 0.6052925088 & -2.9498820638\end{array}$

H $3.18288028191 .0693651849-3.7102214295$

C $2.7656369586-0.723509621-2.601416725$

H $3.5547506398-1.2971858944-3.0758113865$

C $1.9354432643-1.3372176431-1.6623695335$

H $2.0753322931-2.3842772577-1.4196074311$

C $0.918689932-0.6051049384-1.0686674221$

O $-0.020487457-0.3715864987 \quad 1.1129817803$

$\begin{array}{lllll}0 & -0.1271134634 & 1.0424335177 & 0.8606661949\end{array}$

TS Bisaldehyde $2 \cdot \mathrm{O}_{2}$ In plane $\mathrm{H}$ Anthra

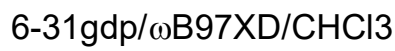
O $1.6113772037 \quad 7.36911960951 .5489029972$
O $2.4441128213 \quad 4.8653208233 \quad 1.6558286392$
H $2.461499944 \quad 5.8377116728 \quad 1.7825387348$
O $0.243554362-7.7183294504-0.0913852413$
O $-0.0973998282-5.7067135105-1.7513665803$
H $-0.0020603359-6.635744446-1.4476501572$
C $0.5907571243 \quad 6.9551407849 \quad 1.0063846292$
H -0.20099833997 .66498513450 .7078231838$
$\begin{array}{llll}\text { C } & 0.3383409207 & 5.5500206391 & 0.7168203337\end{array}$
C 1.28653700374 .56204989951 .0598203185
$\begin{array}{llll}\text { C } & 1.0167295245 & 3.2249998017 & 0.7682548079\end{array}$
H $1.75607639782 .4834976507 \quad 1.0441712284$
$\begin{array}{llll}\text { C }-0.1695181908 & 2.8452305467 & 0.1399860337\end{array}$
C - $-1.11353253993 .8287458306-0.1869187658$
H -2.055359106 $3.5864809767-0.6454918011$
C $-0.8524659703 \quad 5.1567332843 \quad 0.0985702262$
H $-1.5874628497 \quad 5.9149408957-0.157171836$
C $-0.305453998 \quad 1.3434496669-0.1156300485$
C $-0.1245514056-1.2018123170 .0360460182$
C $-0.0046668608-2.69326180940 .2621654016$
C $0.1952337292-3.215525768 \quad 1.5482054266$
H $0.2659209466-2.5530264292 .3996421076$
C $0.2991152408-4.5835203415 \quad 1.7129817933$
H $0.4548663519-4.99892246172 .7048827956$
C $0.2063106236-5.4569252195 \quad 0.6214433734$
C $0.0018302117-4.9255410474-0.6717746586$
C $-0.1012360605-3.5425061357-0.8356871736$

H $-0.2622452798-3.1529421771-1.8351077034$

$\begin{array}{llll}\text { C } & 0.3169349777 & -6.8947410557 & 0.817538042\end{array}$

H $0.4756903115-7.2355096358 \quad 1.8559626288$

C $-1.58538056210 .6623155645-0.6100406931$

C - $2.75190755541 .1934814626-1.1468993057$

H $-2.8632639946 \quad 2.2463221892-1.3503449623$

C $-3.81936509280 .3576392618-1.4788761214$

H $-4.71885736140 .7918247565-1.9024111492$

C $-3.7367919847-1.0099886179-1.2683924051$

H $-4.5744710701-1.654842673-1.5113579565$

C $-2.5607604395-1.560041448-0.7617464107$

H $-2.4850314683-2.6310963588-0.6156515999$

C $-1.4863326131-0.7352173209-0.4663305329$

C $0.83351728230 .7867301564-0.9609757459$

C $1.70973742761 .5133776201-1.7540354957$

H $1.61956911322 .5912376976-1.8299077734$

C $2.71466456040 .8427342406-2.4509175922$

H $3.3968728008 \quad 1.4036394547-3.080947621$

C $2.8506531332-0.5353264189-2.3309499178$

H $3.6452843682-1.0505799671-2.8602162279$

C $1.9679184954-1.2658215063-1.534718748$

H $2.0831215862-2.3396762514-1.4432910672$

C $0.9424109916-0.6045497097-0.8746236753$

$\begin{array}{lllll}\text { O } & 0.0738698447 & -0.5797391387 & 1.3285351111\end{array}$

$\begin{array}{llll}\text { O } & -0.1219524712 & 0.8422514047 & 1.2552232262\end{array}$

\section{Bisaldehyde 2. $\mathrm{O}_{2} \mathrm{C} 2 \mathrm{v}$ \\ $6-31 \mathrm{gdp} / \mathrm{m06} / \mathrm{CHCl} 3$}

O 7.6304617888 0. 1.3997467553

O 5.2964050156 0. 2.6454490515

H 6.2750989406 0. 2.5400282047

O -7.6304617888 0. 1.3997467553

O -5.2964050156 0. 2.6454490515

H -6.2750989406 0. 2.5400282047

$\begin{array}{llll}\text { O } & 0.7184124626 & 0 . & 1.2700907742\end{array}$

O -0.7184124626 0. 1.2700907742

$\begin{array}{llll}\text { C } & 6.9989198376 & 0 . & 0.3461552831\end{array}$

H 7.5363513813 0. -0.6254905003

$\begin{array}{llll}\text { C } 5.5532016987 & 0 . & 0.2573461812\end{array}$

$\begin{array}{llll}\text { C } 4.7601110299 & 0.1 .425505443\end{array}$

C 3.3651354092 0. 1.3160865774

H 2.775749071 0. 2.2268434058

$\begin{array}{llll}\text { C } 2.766097971 & 0.0 .0671647307\end{array}$

C 3.5511860949 0. -1.102553501

H 3.0708695476 0. -2.0782213003

C 4.9246388204 0. -0.9969321809

H 5.5460110988 0. -1.8914257115

C 1.2689326333 0. -0.0844994281

C -1.2689326333 0. -0.0844994281

$\begin{array}{llll}C & -2.766097971 & 0 . & 0.0671647307\end{array}$

C -3.5511860949 0. -1.102553501

Page: S72 
H -3.0708695476 0. -2.0782213003

C -4.9246388204 0. -0.9969321809

H -5.5460110988 0. -1.8914257115

C -5.5532016987 0. 0.2573461812

C -4.7601110299 0. 1.425505443

C -3.3651354092 0. 1.3160865774

H -2.775749071 0. 2.2268434058

C -6.9989198376 0. 0.3461552831

H -7.5363513813 0. -0.6254905003

C $0.6998938254 \quad 1.2394041623 \quad-0.7461022655$

C $1.3993237344 \quad 2.3412868587 \quad-1.215745507$

H $2.4861893875 \quad 2.3565426924-1.1925370496$

C $0.6945461728 \quad 3.4335720257-1.7194910578$

H $1.23816552924 .2928116226-2.1038719474$

C $-0.6945461728 \quad 3.4335720257-1.7194910578$

H -1.2381655292 $4.2928116226-2.1038719474$

C $-1.3993237344 \quad 2.3412868587 \quad-1.215745507$

H -2.4861893875 2.3565426924 -1.1925370496

C $-0.6998938254 \quad 1.2394041623-0.7461022655$

C $0.6998938254-1.2394041623-0.7461022655$

C $1.3993237344-2.3412868587-1.215745507$

H 2.4861893875 -2.3565426924 -1.1925370496

C $0.6945461728-3.4335720257-1.7194910578$

H $1.2381655292-4.2928116226-2.1038719474$

C $-0.6945461728-3.4335720257-1.7194910578$

H -1.2381655292 $-4.2928116226-2.1038719474$

C $-1.3993237344-2.3412868587-1.215745507$

H -2.4861893875 $-2.3565426924-1.1925370496$

C $-0.6998938254-1.2394041623-0.7461022655$

TS Bisaldehyde 2. $\mathrm{O}_{2}$ Phenol in plane $\mathrm{H}$ Anthra PheOHCHO $\mathrm{O} 2$ bridge $6-31 \mathrm{gdp} / \mathrm{m06} / \mathrm{CHCl} 3$

$\begin{array}{lllll}\text { O } & 1.582899625 & 7.3717011691 & 1.5641306897\end{array}$

O $2.4363849971 \quad 4.8593357584 \quad 1.6635608088$

H $2.4543131897 \quad 5.8329681445 \quad 1.798972604$

O $0.2417301511-7.7170897323-0.0779572527$

O $-0.1038736593-5.6997795231-1.7563312186$

H $-0.0093372875-6.6325266469-1.4569770954$

C $0.5719690501 \quad 6.9434498053 \quad 1.0155209905$

H $-0.2361106903 \quad 7.64077737190 .7098325143$

C $0.3330050427 \quad 5.5438193284 \quad 0.7193515477$

C $1.2842055671 \quad 4.5575258797 \quad 1.0610033214$

C $1.0203417799 \quad 3.2227378088 \quad 0.7608919944$

H $1.7639975945 \quad 2.4829939945 \quad 1.0415671759$

C $-0.1626187217 \quad 2.8393594791 \quad 0.1271457454$

C $-1.1079716434 \quad 3.8218237167-0.1996964309$

H $-2.04934743493 .5780403862-0.6648778034$

C $-0.8521939489 \quad 5.1483613625 \quad 0.0935018684$

H - $1.58719659115 .9107284961-0.1606936606$

C $-0.2975855159 \quad 1.3440486589-0.1297329921$
C $-0.1237807556-1.20139881630 .0253806074$

C $-0.0060934416-2.68687299490 .2546416239$

C $0.1948171479-3.2083755409 \quad 1.5407479257$

H 0.267156168 -2.5425530933 2.3926610582

C $0.2984913744-4.5757046052 \quad 1.7053260407$

H $0.4558209445 \quad-4.99650396882 .6975502497$

C $0.2042336353 \quad-5.4505707083 \quad 0.6162098187$

C $-0.0021559431-4.9205359246-0.6781103113$

C $-0.1040583362-3.5387938074-0.8420300102$

H $-0.2666594844-3.1514798977-1.8459005295$

C $0.3151113962-6.88126030910 .8190591313$

H $0.4765174289 \quad-7.2033269641 \quad 1.8691879598$

C $-1.5763288747 \quad 0.6668451914 \quad-0.6145314191$

C $-2.7483716529 \quad 1.1972170232-1.1401784814$

H -2.8622239539 2.2520503558 -1.346712278

C $-3.8198851747 \quad 0.3636561511-1.4612507797$

H $-4.72359398340 .8007032064-1.8781153057$

C -3.7390425253 -1.0029728988 -1.2501361036

H $-4.5819209362-1.6474938277-1.4849427453$

C $-2.5596725152-1.5535975404-0.7545878281$

H -2.4823236474 $-2.6274010325-0.607260177$

C $-1.4800162998-0.7321688052-0.4707902522$

C $0.83803339210 .7845400938-0.9670043211$

C $1.72170363821 .5060091519-1.7560631502$

H $1.6345257912 \quad 2.5869321127$-1.833590167

C $2.7269974850 .8324630897-2.4481019479$

H $3.4147583124 \quad 1.3918466857-3.0769722797$

C $2.8579298018-0.5449010504-2.3269756065$

H $3.6547651942-1.0639709403-2.8534304085$

C $1.969146032-1.2713124555-1.5351507824$

H $2.0793145573 \quad-2.3485576399-1.4422731306$

C $0.9416370133-0.6084834757-0.8805812077$

O $0.07601377-0.5780896069 \quad 1.3205905175$

O $-0.1120151425 \quad 0.8438671941 \quad 1.2450295731$

Macrocycle 1 - Conformer A

$6-31 \mathrm{~g}(\mathrm{~d}, \mathrm{p}) / \omega \mathrm{B} 97 \mathrm{XD} / \mathrm{CHCl} 3$

C $-0.0030981903-5.9907807978-4.576110694$

C $-0.8350564621-6.0754936543-3.4667884832$

C $-0.9432631336-7.2684490908-2.7435980877$

C $-0.1992642652-8.4004604872-3.1530817647$

C $0.630547417-8.2946808358-4.2789262113$

C $0.7344939369-7.1126121598-4.9875572734$

C $-0.2681714279-9.6529016647-2.4190950504$

H $0.3474767989-10.4811018889-2.791544978$

C $-1.0780682587-11.012358227-0.6982610925$

C $-1.1695340974-12.2307453405-1.3889142001$

H - $1.2054247664-12.2106575222-2.4713207955$

C $-1.2568546142-13.4347181667-0.7076030425$

C $-1.2568546142-13.4347181667 \quad 0.7076030425$

C $-1.1695340974-12.2307453405 \quad 1.3889142001$

Page: S73 
H -1.2054247664 -12.2106575222 2.4713207955

C $-1.0780682587-11.012358227 \quad 0.6982610925$

C $-0.2681714279 \quad-9.6529016647 \quad 2.4190950504$

H $0.3474767989-10.48110188892 .791544978$

C $-0.1992642652 \quad-8.4004604872 \quad 3.1530817647$

C $-0.9432631336-7.2684490908 \quad 2.7435980877$

C $-0.8350564621-6.0754936543 \quad 3.4667884832$

C $-0.0030981903 \quad-5.9907807978 \quad 4.576110694$

C $0.7344939369-7.1126121598 \quad 4.9875572734$

C $0.630547417 \quad-8.2946808358 \quad 4.2789262113$

N -0.9976874978 -9.780559077 -1.3694927548

N -0.9976874978 $-9.780559077 \quad 1.3694927548$

O $-1.751571264-7.2962604022-1.6809632501$

H $-1.6820859126-8.2010903001-1.2823891697$

O $-1.751571264-7.2962604022 \quad 1.6809632501$

H -1.6820859126 $-8.2010903001 \quad 1.2823891697$

O $-1.3679051152-14.6504156772 \quad 1.2905711903$

O $-1.3679051152-14.6504156772-1.2905711903$

C -1.3980329368 $-14.701877026-2.703593858$

H $-0.4769268071-14.2965745115-3.1390847649$

H -2.2597531911 -14.1568480757 -3.1064472391

H $-1.4853613139-15.7558552887-2.9645031966$

C -1.3980329368 $-14.701877026 \quad 2.703593858$

H -2.2597531911 -14.1568480757 3.1064472391

H - $0.4769268071-14.2965745115 \quad 3.1390847649$

H -1.4853613139 -15.7558552887 2.9645031966

H $1.2025311833-9.16514163814 .5891970952$

H $1.3819323911-7.0414114557 \quad 5.8545389755$

H $1.2025311833-9.1651416381$-4.5891970952

H $1.3819323911-7.0414114557-5.8545389755$

H - $-1.4072618679-5.2151787255 \quad 3.1367304247$

H - $-1.4072618679-5.2151787255-3.1367304247$

C $0.1132448502-4.702761604-5.321859606$

C $-0.6301738746-4.5045267053-6.4972217863$

C $0.9678253956-3.6947529046-4.8440394876$

C $-1.5211510811-5.507252877-7.0026552861$

C $1.746780319-3.8695574114-3.6533626822$

C $-2.2458436291-5.3003986203-8.137514341$

H $-1.6143335234-6.4410943337-6.459417678$

C $2.5782691077-2.888722526-3.2037323777$

H $1.6620155792-4.8029641054-3.1083960043$

H -2.9165117098 $-6.0716234068-8.502336283$

H $3.1571062013-3.0400387615-2.2983696321$

C $0.1132448502-4.702761604 \quad 5.321859606$

C $-0.6301738746-4.5045267053 \quad 6.4972217863$

C $0.9678253956-3.6947529046 \quad 4.8440394876$

C $-0.5165487477-3.2659703065 \quad 7.2138192937$

C - $1.5211510811-5.507252877 \quad 7.0026552861$

C $1.0839148258-2.4567493618 \quad 5.5618577141$

C $1.746780319 \quad-3.8695574114 \quad 3.6533626822$

C $0.3397110989-2.2582394825 \quad 6.737713195$

C $-1.3041973312-3.0894378773 \quad 8.3985222547$

C $-2.2458436291 \quad-5.30039862038 .137514341$
H $-1.6143335234-6.4410943337 \quad 6.459417678$

C $1.9776699542-1.4564590208 \quad 5.0559062414$

H $1.6620155792-4.80296410543 .1083960043$

C $2.5782691077-2.888722526 \quad 3.2037323777$

C - $2.1361675913-4.07090241048 .8464454199$

H $-1.2308488082-2.15113443518 .9368609777$

H $-2.9165117098 \quad-6.0716234068 \quad 8.502336283$

C $2.6964633606-1.6628545162 \quad 3.9172500245$

H $2.0735702198-0.52187281385 .5968367216$

H $3.1571062013-3.0400387615 \quad 2.2983696321$

H -2.7252066597 $-3.9157966606 \quad 9.7446177341$

H $3.3652482834-0.8910873042 \quad 3.5503609045$

C $0.459638423 \quad-0.9725173519 \quad 7.4863698796$

C $-0.2067721572 \quad 0.1588560805 \quad 7.0325784004$

C $1.2472334506-0.904404354 \quad 8.6473815681$

C $-0.1032086496 \quad 1.3744890495 \quad 7.7181414241$

H $-0.8141172884 \quad 0.1205349418 \quad 6.1346440458$

C $1.3520623997 \quad 0.2914400198 \quad 9.3316087134$

H 1.7661563663 -1.7901036541 8.9969055037

C $0.6866254822 \quad 1.4452763918 \quad 8.8915089396$

$\begin{array}{lllll}\text { O } & -0.7596600558 & 2.433049923 & 7.2369736464\end{array}$

H $1.9610574891 \quad 0.3508342227 \quad 10.2298272932$

C $0.82215217592 .6876841169 \quad 9.6315343942$

H $-0.5605197387 \quad 3.1997572794 \quad 7.8360737287$

H $1.4691896784 \quad 2.6733487436 \quad 10.5173901826$

N $0.2214608185 \quad 3.7574752016 \quad 9.2505610275$

C $0.3230748222 \quad 4.95320041799 .9811711869$

C $0.3429832835 \quad 4.9773987294 \quad 11.3838975352$

H $0.2695400754 \quad 4.0404347821 \quad 11.9225322965$

C $0.4094415228 \quad 6.1759772942 \quad 12.0774507485$

$\begin{array}{lllll}\text { O } & 0.4313334412 & 6.2916243862 & 13.4252675071\end{array}$

C $0.4104478651 \quad 5.1006833292 \quad 14.1877708216$

H $1.275225795 \quad 4.4655404503 \quad 13.9620212408$

H $-0.5113530609 \quad 4.5318507003 \quad 14.0182687245$

H $0.4539735523 \quad 5.4106306395 \quad 15.2311340716$

C $0.459638423-0.9725173519-7.4863698796$

C $-0.20677215720 .1588560805-7.0325784004$

C $-0.1032086496 \quad 1.3744890495 \quad-7.7181414241$

C $0.6866254822 \quad 1.4452763918-8.8915089396$

C $1.3520623997 \quad 0.2914400198 \quad-9.3316087134$

C $1.2472334506-0.904404354-8.6473815681$

C $0.82215217592 .6876841169-9.6315343942$

H $\quad 1.4691896784 \quad 2.6733487436-10.5173901826$

C $0.32307482224 .9532004179-9.9811711869$

C $0.34298328354 .9773987294-11.3838975352$

H $0.2695400754 \quad 4.0404347821 \quad-11.9225322965$

C $0.4094415228 \quad 6.1759772942 \quad-12.0774507485$

C $0.45429912327 .3941634596-11.3585082311$

C $0.4160772817 \quad 7.3699305293 \quad-9.9729096257$

H 0.48841122848 .2929246948 -9.4105941769

C $0.3296949284 \quad 6.1572699518 \quad-9.2724545503$

C $-0.2948244696 \quad 6.9782617392 \quad-7.166006057$

H $-0.8752997934 \quad 7.7842807907$-7.6316781689

Page: S74 
C $-0.26906017116 .9366828268-5.7144716218$

C $0.4280244473 \quad 5.9160927043-5.0231646397$

C $0.42973429425 .9125195224-3.6234510373$

C $-0.24724661016 .8933816469-2.9097150515$

C $-0.94398186527 .90381619-3.5926006282$

C $-0.94850947097 .9154765106-4.9741805294$

N $0.22146081853 .7574752016-9.2505610275$

N $0.3236209766 \quad 6.098209168-7.8685421443$

$\begin{array}{llll}\text { O } & -0.7596600558 & 2.433049923 & -7.2369736464\end{array}$

H - $0.5605197387 \quad 3.1997572794-7.8360737287$

O $1.090785852 \quad 4.9489982133-5.6624485713$

H $0.9704670495 .1041474316-6.6361256739$

O $0.53799312918 .514671959-12.111933623$

$\begin{array}{lllll}0 & 0.4313334412 & 6.2916243862 & -13.4252675071\end{array}$

C $0.41044786515 .1006833292-14.1877708216$

H $-0.51135306094 .5318507003-14.0182687245$

H $1.2752257954 .4655404503-13.9620212408$

H $0.4539735523 \quad 5.4106306395-15.2311340716$

C $0.56074928729 .7590573254-11.4402661575$

H $1.4412501729 .8498989815-10.7933658651$

H $-0.34582593629 .9076136402-10.8417044639$

H - $1.48657790168 .6941826652-5.5082618949$

H - $1.47160217988 .6661655799-3.0302154078$

H $1.96105748910 .3508342227-10.2298272932$

H $1.7661563663-1.7901036541-8.9969055037$

H $0.96729816665 .124186308-3.107572429$

H $-0.81411728840 .1205349418-6.1346440458$

C $0.3397110989-2.2582394825-6.737713195$

C $-0.5165487477-3.2659703065-7.2138192937$

C $1.0839148258-2.4567493618-5.5618577141$

C $-1.3041973312-3.0894378773-8.3985222547$

C $1.9776699542-1.4564590208-5.0559062414$

C -2.1361675913 $-4.0709024104-8.8464454199$

H - $-1.2308488082-2.1511344351-8.9368609777$

C $2.6964633606-1.6628545162-3.9172500245$

H $2.0735702198-0.5218728138-5.5968367216$

H -2.7252066597 -3.9157966606 -9.7446177341

H $3.3652482834-0.8910873042-3.5503609045$

C $-0.2357209193 \quad 6.8764267412-1.4170131792$

C $-1.1037429876 \quad 6.0203915101-0.7180024471$

C $0.63753256747 .7268116649-0.7176764703$

C $-1.1037429876 \quad 6.0203915101 \quad 0.7180024471$

C - $2.01232124775 .1464929171-1.4005319253$

C $0.6375325674 \quad 7.72681166490 .7176764703$

C $1.54992718218 .5968404102-1.4000183431$

C $-0.2357209193 \quad 6.8764267412 \quad 1.4170131792$

C - $-2.01232124775 .1464929171 \quad 1.4005319253$

C $-2.85493656914 .3272078769-0.711710938$

H -2.0181873687 $5.1446275109-2.4846610114$

C $1.54992718218 .5968404102 \quad 1.4000183431$

H $1.55951471998 .5936134437-2.4842336467$

C $2.39771593559 .4114019313-0.7117181973$

C $-2.8549365691 \quad 4.32720787690 .711710938$
H -2.0181873687 5.14462751092 .4846610114

H -3.5328018147 $3.6709969066-1.2478185063$

C $2.3977159355 \quad 9.4114019313 \quad 0.7117181973$

H $1.55951471998 .5936134437 \quad 2.4842336467$

H $3.082535008410 .0605212517-1.2478252331$

H -3.5328018147 $3.6709969066 \quad 1.2478185063$

H $3.0825350084 \quad 10.0605212517 \quad 1.2478252331$

C $-0.2472466101 \quad 6.89338164692 .9097150515$

C $0.42973429425 .9125195224 \quad 3.6234510373$

C $-0.94398186527 .90381619 \quad 3.5926006282$

C $0.4280244473 \quad 5.9160927043 \quad 5.0231646397$

H $0.9672981666 \quad 5.124186308 \quad 3.107572429$

C $-0.94850947097 .9154765106 \quad 4.9741805294$

H - $1.4716021798 \quad 8.66616557993 .0302154078$

C $-0.2690601711 \quad 6.9366828268 \quad 5.7144716218$

O $1.090785852 \quad 4.9489982133 \quad 5.6624485713$

H -1.4865779016 $8.6941826652 \quad 5.5082618949$

C $-0.2948244696 \quad 6.9782617392 \quad 7.166006057$

H $0.970467049 \quad 5.1041474316 \quad 6.6361256739$

H $-0.87529979347 .7842807907 \quad 7.6316781689$

N $0.3236209766 \quad 6.098209168 \quad 7.8685421443$

C $0.3296949284 \quad 6.1572699518 \quad 9.2724545503$

C $0.4160772817 \quad 7.36993052939 .9729096257$

H $0.4884112284 \quad 8.2929246948 \quad 9.4105941769$

C $0.45429912327 .3941634596 \quad 11.3585082311$

$\begin{array}{llll}\text { O } & 0.5379931291 & 8.514671959 & 12.111933623\end{array}$

C $0.5607492872 \quad 9.7590573254 \quad 11.4402661575$

H $-0.3458259362 \quad 9.9076136402 \quad 10.8417044639$

H $1.4412501729 .8498989815 \quad 10.7933658651$

H $0.607215395210 .5200008627 \quad 12.2183284212$

H $0.6072153952 \quad 10.5200008627-12.2183284212$

Macrocycle 1 - Conformer A-(HB) 6-31g(d,p)/wB97XD/CLF

C $5.8339973296-4.522532592 \quad 0.185315497$

C $4.7882627062-4.9491441428-0.6234576084$

C $4.420684244-6.2989049886-0.6635954238$

$\begin{array}{llll}\text { C } & 5.1274115719 & -7.2367066235 & 0.1262717227\end{array}$

C $6.178514366-6.78400849110 .9372128296$

C $6.5350584702-5.4492707420 .9737690371$

C $4.7745859777-8.64659944990 .1187232776$

H $5.3585183936-9.30747761340 .771234266$

C $3.5120799859-10.4701727653-0.6223417041$

C $4.514434726-11.4522170338-0.6474503778$

H $5.5499372244-11.1359897952-0.6804873387$

C $4.1943898256-12.8007380353-0.673954658$

C $2.8345913693-13.1932464677-0.6770918109$

C $1.8451122407-12.2225704914-0.6557661674$

H $0.8001719039-12.5055163505-0.6938363379$

C $2.1705159858-10.8579652995-0.6285208169$

C $0.1353839171-9.97674383430 .1129192761$

H -0.0003991323 -10.83588316690 .781412436$

Page: S75 
C $-0.9093777437 \quad-8.9665667952 \quad 0.1165245989$

C $-0.8153826605-7.8129207697-0.697911662$

C $-1.8272014019-6.8480262785-0.6434471387$

$\begin{array}{llll}\text { C }-2.9164213407 & -7.0092690305 & 0.2034336588\end{array}$

C -3.0173327205 $-8.1559834737 \quad 1.0075400145$

C - $2.0221521722-9.11379805220 .9575405451$

N $3.8112021911-9.0974219484-0.60144186$

N $1.1843433996-9.8573445534-0.618564734$

O $3.4066915299-6.6580990508-1.4548278503$

H $3.2791040876-7.6347895075-1.3445204786$

O $0.2152510104-7.6073069291-1.5218726104$

H $0.8410717849-8.3672336133-1.4041426835$

O $2.6113212775-14.5267257881-0.723959365$

O $5.093915301-13.8104705781-0.719909141$

C $6.4658562462-13.4680690507-0.7449470333$

H $6.7569313317-12.91331579510 .1549760294$

H $6.7149800936-12.8749894226-1.6327111732$

H $7.0106816001-14.4107608871-0.7778953794$

C $1.2679376391-14.9676658111-0.756954312$

H $0.7463844216-14.5979731271-1.6475771322$

H $0.7208976444-14.65355313550 .1399218609$

H $1.3092002823-16.0556789769-0.7901405327$

H -2.0902283395 $-9.9997733567 \quad 1.5833381582$

H $-3.8705319234-8.27706361261 .6657780042$

H $6.7168549043-7.50594641191 .5456340385$

H $7.3505152137-5.11053849481 .6031863975$

H -1.7361525811 -5.9649737386 - 1.2667157385

H $4.237427251-4.2429796567-1.2354545012$

C $6.2166860125-3.07964412630 .2121648899$

C $7.2760012247-2.6266894865-0.5918583025$

C $5.5229319572-2.1838061757 \quad 1.0425832639$

C $7.9925798335-3.5129021469-1.4613014661$

C $4.4397216358-2.6149673372 \quad 1.8766103131$

C $9.0112093693-3.061880317-2.2453430553$

H $7.7052153821-4.5580506091-1.4897972498$

C $3.7807444257-1.7393767244 \quad 2.6857606682$

H $4.1480013522-3.65899167951 .851689885$

H $9.5394037405-3.748613611-2.8988884856$

H $2.9612244201-2.0853171907 \quad 3.3073086229$

C -3.9687762006 $-5.9526704417 \quad 0.2708541289$

C $-5.1509857614-6.0905650148-0.474797995$

C $-3.7701896841-4.8248412391 \quad 1.0852557015$

C $-6.1626114044-5.0745546872-0.4040939527$

C $-5.3771819536-7.2225693061-1.3244343676$

C $-4.7827274726-3.8097746367 \quad 1.1586683863$

C $-2.5782691536-4.6587143171 \quad 1.8642198343$

$\begin{array}{llll}\text { C }-5.9662820828 & -3.9481681279 & 0.4127679757\end{array}$

C $-7.3491456977-5.2382603618-1.1916277802$

C $-6.5232227377-7.3414514378-2.051273623$

H $-4.6118600622-7.9884922621-1.3841582269$

C $-4.5558068148-2.6811763346 \quad 2.0132295112$

H - $-1.810768031-5.422538031 \quad 1.8105353418$

C $-2.4005957065-3.5658320912 \quad 2.6576820635$
C $-7.524979036-6.332133121-1.9845010208$

H -8.1112547971 $-4.4680753319-1.1505621766$

H $-6.6744498022-8.2052046122-2.6906191217$

C $-3.4062799014-2.5615733193 \quad 2.7343801933$

H $-5.3189306959-1.91393318772 .0772469256$

H - $1.4895843275-3.45779438393 .2373644172$

H $-8.4297923713-6.4354379856-2.5747294782$

H -3.2538583325 $-1.6975696129 \quad 3.3729907057$

$\begin{array}{llll}\text { C }-7.0215480392 & -2.8961079911 & 0.4974494614\end{array}$

C $-6.8771928444-1.7087356413-0.2090974869$

C $-8.1529074653-3.100062875 \quad 1.3044489456$

C -7.8443426377 $-0.7010954701-0.1204137538$

H $-6.0054449974-1.5373843409-0.8313757038$

C $-9.1132764751-2.1109512651 .3950884311$

H -8.2604145866 -4.02896895151 .8534630603$

C -8.9842254928 $-0.9023353881 \quad 0.6948390411$

$\begin{array}{llll}\text { C } & -7.653382928 & 0.4255902022 & -0.8109964976\end{array}$

H -9.9876049102 $-2.2595036714 \quad 2.0233253214$

C $-9.9994680525 \quad 0.12646860280 .8338469012$

H -8.4153058516 $1.0286289276-0.6093449858$

H -10.8402507604 -0.09075898521 .50427267$

$\begin{array}{llll}\text { N } & -9.9025426697 & 1.2497344649 & 0.2176893027\end{array}$

$\begin{array}{llll}\text { C }-10.9001238456 & 2.231314094 & 0.3500050731\end{array}$

C $-12.2650217363 \quad 1.9068062161 \quad 0.3713613388$

H $-12.5539649850 .8683520417 \quad 0.2648121183$

C - $-13.2327408121 \quad 2.8928697807 \quad 0.4836635333$

O $-14.5665470643 \quad 2.6713152206 \quad 0.5092001305$

C $-15.0127476505 \quad 1.3310985816 \quad 0.4351645148$

H -14.6322597156 $0.7356013979 \quad 1.2734652684$

H - $-14.7140154627 \quad 0.8606438388$ - 0.5089414301

H - $-16.0999751531 \quad 1.37285220760 .4873865899$

C $7.3792171436 \quad 1.0868953254 \quad 0.3168401748$

C $6.64837304012 .0438348091-0.3774712289$

C $7.0392759431 \quad 3.387685789-0.3726178031$

$\begin{array}{llll}\text { C } 8.1975747938 & 3.770457245 & 0.3476383865\end{array}$

C $8.911205184 \quad 2.7921421536 \quad 1.0539396637$

C $8.5175703591 \quad 1.4672040695 \quad 1.0451286104$

C $8.6500063015 \quad 5.15236409810 .36030365$

H 9.51890668925 .39009364580 .9863999448

C $8.45457703827 .3794202938-0.391286276$

C $9.80337786187 .7630912188-0.3208236578$

H $10.5612680536 \quad 6.9954989033-0.2238468055$

C $10.1712708392 \quad 9.094707501-0.4203356875$

C $9.171486426710 .0816146706-0.6037425022$

C $7.84118151359 .7009610839-0.6754063993$

H $7.073843591410 .4433200154-0.857260518$

C $7.46503305498 .3517003683-0.5657416475$

C $5.19935627718 .6170643463-0.135824007$

H 5.42795918619 .53944910070 .4187741659

C $3.79382572138 .1988701853-0.1900906515$

$\begin{array}{llll}\text { C } 2.7525677241 & 9.1183158018 & 0.0236614807\end{array}$

$\begin{array}{lll}\text { C } 1.4264116122 & 8.6878988242 & 0.0334026124\end{array}$

C $1.11206069617 .3480009-0.1696907129$

Page: S76 
C $2.1450022208 \quad 6.4269795226 \quad-0.395998094$

C $3.4611732014 \quad 6.8534415074-0.4086354121$

N $8.0373660115 \quad 6.0447346231-0.3276313878$

N $6.1330258787 \quad 7.9191424365-0.6537167064$

O $\quad 6.3017423905 \quad 4.2673667021-1.0583050159$

H $6.7396135726 \quad 5.1579744394-0.9664908214$

O $2.949986672 \quad 10.447236239 \quad 0.2263584816$

H $3.848376853910 .701081714-0.0021379467$

$\begin{array}{lllll}\text { O } & 9.6217298229 & 11.3520541852 & -0.7197158477\end{array}$

O $11.4436333051 \quad 9.5536419103-0.383959915$

C $12.48084319418 .6040417117-0.2347282414$

H $12.50010327567 .8964826171-1.0720030526$

H $12.3840099714 \quad 8.0494259527 \quad 0.7062352254$

H $13.40998131349 .1725183189-0.2230889061$

C $8.66513364412 .3730702568-0.9245317853$

H $7.9568449037 \quad 12.431262666-0.08937231$

H $8.1122482145 \quad 12.2230926191-1.8593307385$

H $4.2687954416 .1447350863-0.5617614482$

H $1.9068002965 \quad 5.3804382443 \quad-0.5526250479$

H $9.7945258622 \quad 3.0917917971 \quad 1.6118818867$

H $9.08285345840 .7176920736 \quad 1.5879772129$

H $0.6435239218 \quad 9.4206843074 \quad 0.1969726616$

H $5.7648118707 \quad 1.7630875967 \quad-0.9407594185$

C $6.9670477014 \quad-0.3472265872 \quad 0.2763962282$

C $7.6547893426-1.2426579188-0.5614397324$

C $5.9045097037-0.7999070607 \quad 1.0770209276$

C $8.7273848252-0.8115055025-1.4094431689$

C $5.1887207941 \quad 0.0829297114 \quad 1.9506433502$

C $9.3832800397-1.6882624262-2.2201535324$

H $9.00933643290 .23529833-1.4007409155$

$\begin{array}{llll}\text { C } 4.1625959388 & -0.368572021 & 2.7246297186\end{array}$

H $5.4777111129 \quad 1.1273271693 \quad 1.9851497416$

H $10.1904632483-1.3398480937-2.8563566557$

H $3.63193266890 .3172424757 \quad 3.3770784514$

C $-0.31613091856 .9165319336-0.149906378$

C $-0.9601661016 .5650938172-1.3498822873$

C $-1.0216030724 \quad 6.8862409208 \quad 1.0667160336$

C $-2.3431721447 \quad 6.1791943813-1.3323105892$

C $-0.27867252896 .5962479004-2.6110108716$

C - $-2.4128783542 \quad 6.5299166902 \quad 1.0795890094$

C $-0.3874668867 \quad 7.196970904 \quad 2.3147851643$

C $-3.05746560336 .1831668835-0.1211080626$

C $-2.9593034138 \quad 5.7928190239-2.5679034301$

C $-0.9078229032 \quad 6.2359148244-3.7643357062$

H $0.7581035564 \quad 6.9114813586-2.635539951$

C $-3.111543566 \quad 6.5577777424 \quad 2.3315083237$

H $0.669346155 \quad 7.4374490061 \quad 2.3160495007$

C $-1.0851508714 \quad 7.1905815588 \quad 3.4846904706$

C $-2.2674363303 \quad 5.8168536507$-3.7410502926

H $-3.9948845108 \quad 5.4726107982-2.5551359801$

H $-0.37102600296 .2641579252-4.7070248655$

C -2.472996637 $6.8768739703 \quad 3.4916394269$

H $-4.1676523734 \quad 6.31443094312 .3435709475$
H $-0.5832565816 \quad 7.4262021993 \quad 4.4175773081$

H -2.7523325204 $5.5160452905-4.6640499407$

H $-3.0215892108 \quad 6.88905700794 .4279057969$

C $-4.5112840145 \quad 5.845532891-0.1174701918$

C $-4.95176591694 .6294402518 \quad 0.3905661912$

C $-5.4399729991 \quad 6.7686516857 \quad-0.6270336692$

C $-6.3152866281 \quad 4.312916765 \quad 0.4111902443$

H $-4.2463069634 \quad 3.90571833170 .7845661813$

C $-6.7860215192 \quad 6.4588718151 \quad-0.6207469652$

H $-5.09177978947 .7154914473-1.02472306$

C -7.2524621302 $5.2408800637-0.1042898796$

$\begin{array}{lllll}\text { O } & -6.6869690113 & 3.1349521837 & 0.918734156\end{array}$

H -7.5074349211 $7.1686139632-1.0169257398$

C -8.6748992804 $4.9477905537-0.114458635$

H -7.6760999562 $3.0819561356 \quad 0.8469580734$

H $-9.3307325605 \quad 5.6955199199-0.5770158467$

N $-9.1330725149 \quad 3.8545774252 \quad 0.3813058326$

C -10.50898541893 .57191007340 .4008401676$

C -11.4883824086 $4.5682166742 \quad 0.5406459618$

H -11.1742541696 5.59840668550 .6536316273

C $-12.8359507826 \quad 4.24821246340 .580478803$

$\begin{array}{lllll}\text { O } & -13.8423403497 & 5.1426441434 & 0.7139026985\end{array}$

C -13.4997032412 $6.5126159304 \quad 0.7902531219$

H $-12.9669679008 \quad 6.8428714892-0.1094187098$

H $-12.885434762 \quad 6.7242050807 \quad 1.6734617525$

H -14.4414303875 $7.0542133043 \quad 0.870192252$

H $9.2269839077 \quad 13.3043290104-0.9847495183$

\section{Macrocycle 1 - Conformer B}

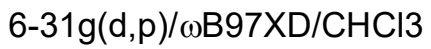

C $-0.4175412415 \quad 6.8662345789-7.1397476137$

H - $-1.07255226667 .6515962471-7.5371349811$

C $0.0032414906 \quad 6.128904695-9.3111081835$

C $0.06953027857 .3677145097-9.9668184171$

H $0.27345142068 .2546604846-9.3795402196$

C $-0.0818568718 \quad 7.4581144174-11.3414958257$

C $-0.3135065994 \quad 6.2812777162-12.0935444073$

C $-0.3605100485 \quad 5.0576554421-11.4465518307$

H $-0.57507234814 .1597253147-12.0124435836$

C $-0.1777096304 \quad 4.9609809375-10.0569340511$

N $0.1648195681 \quad 6.0247649888-7.9168736395$

O $-0.4806313046 \quad 6.4638006281-13.4239707736$

O $-0.0282456702 \quad 8.6056987947-12.053896004$

C $0.17892726169 .8120739101-11.3445808411$

H - $0.6229862529 .9922292393-10.6189733269$

H $1.14440364479 .8109471441-10.8253609242$

H $0.173545774610 .6047664955-12.091633828$

C $-0.69158879365 .316995018-14.2239189563$

H $0.1508306737 \quad 4.6187740599-14.1528264416$

H - $1.61677063834 .798256893-13.9461031363$

H $-0.7759550853 \quad 5.6762857338-15.2488037384$ 
C $0.428257809-11.0213119251-0.7049648523$

C $0.5338685588-12.2533574107-1.3728655746$

H $0.6207449367-12.2563935839-2.4522251734$

C $0.5747677161-13.448723828-0.675156779$

O $0.6943003537-14.6730523509-1.2375581306$

C $0.7817923314-14.7439654718-2.6473968506$

H -0.1145524828 $-14.3312015196-3.1253818298$

H $1.6675180118-14.2169252808-3.0210968653$

H $0.8640798849-15.8024897507-2.8908476653$

C $-0.2631394052 \quad 6.8034404244 \quad 7.1584167558$

H $-0.91931147587 .5783011187 \quad 7.5741890622$

C $0.2222629607 \quad 6.0908655466 \quad 9.3192462254$

C $0.3440885347 \quad 7.3373529183 \quad 9.9526601489$

H $0.5617113733 \quad 8.20685343129 .3447555017$

C $0.2285272748 \quad 7.4546433702 \quad 11.328369995$

C $-0.023287706 \quad 6.2970461596 \quad 12.104601344$

C $-0.1295726647 \quad 5.0673017893 \quad 11.4788446745$

H $-0.3531740705 \quad 4.1886450124 \quad 12.0701992651$

C $0.0135796175 \quad 4.9408071075 \quad 10.0859656977$

C $-0.0078108424 \quad 2.577261341 \quad 9.9670877743$

H $0.1722603177 \quad 2.464085739 \quad 11.0424762281$

N $0.35037611195 .9714586864 \quad 7.9217929226$

N $-0.0957627337 \quad 3.7242721818 \quad 9.3948092509$

O $-0.1458297895 \quad 6.505553273 \quad 13.4361332236$

$\begin{array}{llll}0 & 0.3373408235 & 8.6099318078 & 12.0204715897\end{array}$

C $0.5766446217 \quad 9.7968895169 \quad 11.2882982891$

H $1.53037948889 .74984114 \quad 10.7500037268$

H - $0.23251610349 .9975158581 \quad 10.5763597579$

H $0.6175289186 \quad 10.5999511362 \quad 12.0230356237$

C $-0.3738817093 \quad 5.3798606728 \quad 14.2608548706$

H - $-1.3238870784 \quad 4.889510981214 .0172919334$

H $0.4416198082 \quad 4.6515081721 \quad 14.1788440004$

C $-0.3522896939-9.6223210375 \quad 2.432313758$

H - $0.9794412404-10.4327668682 .8235944518$

N $0.3350076198-9.765802828 \quad 1.3556931491$

C $0.3848202017-11.00327153780 .6923543475$

C $0.4330261535-12.2158409287 \quad 1.3999526153$

H $0.4430918865-12.1842719712 \quad 2.482428918$

C $0.5185120058-13.43022067720 .739500598$

$\begin{array}{lllll}\text { O } & 0.5851930867 & -14.6386119615 & 1.3421563131\end{array}$

C $0.5601980976-14.671607414 \quad 2.7561137604$

H $1.4187192808-14.141400388 \quad 3.1845831154$

H $-0.3670346495-14.23895260763 .1501419822$

H $0.6125315226-15.7236950193 .0332823768$

H $-0.4172395584 \quad 5.7583167462 \quad 15.2813935133$

C $-0.1175731698 \quad 1.3492804157 \quad 9.1992269758$

C $-0.2570054964 \quad 1.37542409697 .7902032224$

$\begin{array}{llll}\text { C }-0.3047046214 & 0.1692708062 & 7.0820793953\end{array}$

C $-0.2414063187-1.0508792586 \quad 7.7450255353$

C $-0.1292709101-1.07853322469 .1455876576$

C $-0.0590853508 \quad 0.107799369 \quad 9.8499457161$

$\begin{array}{llll}\text { O } & -0.3344040925 & 2.5184382008 & 7.1050661499\end{array}$

H $-0.2734806985 \quad 3.2607726463 \quad 7.764104317$
H $0.0421792183 \quad 0.0899100236 \quad 10.931897147$

H - $0.0839162792-2.0311616819 .6617615619$

H $-0.39132940730 .2080561657 \quad 6.0014113901$

C $-0.27635372-2.3245815571 \quad 6.9688469795$

C $0.8795110806-3.12359716796 .8906289481$

C $-1.4559043179-2.7224489631 \quad 6.3134109054$

$\begin{array}{llll}\text { C } 0.8494808015 & -4.3572920399 & 6.1563434215\end{array}$

C $2.1106102553-2.7336267773 \quad 7.5146498446$

C $-1.4720908473-3.9332394152 \quad 5.5408865907$

C $-2.663884791-1.9542738797 \quad 6.3983615163$

C $-0.3220489478-4.740827834 \quad 5.4776379317$

C $2.0295539654 \quad-5.1724022212 \quad 6.1483459192$

C $3.2158992208-3.5277635837 \quad 7.4601674499$

H $2.1524505284-1.78416528598 .0352971713$

C - $2.6736143506-4.27521892814 .8366827088$

H - $2.6686576881-1.0567394492 \quad 7.0056052847$

C $-3.7913390915-2.3305641774 \quad 5.7330328014$

C $3.1698199859-4.77558075896 .7788596162$

H $2.0040123468-6.12112087565 .6254988693$

H $4.136850797-3.21014703147 .9382880907$

C -3.7919434564 -3.50286008774 .9269918092$

H -2.6799973026 -5.16691058884 .2205951776$

H -4.6934011765 -1.7324862646 5.8119640756

H $4.0503569387-5.4094702126 .7580543965$

H $-4.6891470156-3.78060676114 .3833826952$

C $-0.339262922-6.0028024215 \quad 4.6819405804$

C $0.4075124764-6.0914196652 \quad 3.5130203583$

C $-1.0965480673-7.1060952274 \quad 5.1108691219$

C $0.4264936336-7.2707321703 \quad 2.7615529458$

H 0.9990136028 -5.2498050362 3.169033946

$\begin{array}{llll}\text { C }-1.0961917577 & -8.2686127277 & 4.363763468\end{array}$

H -1.6773764756 $-7.0364376795 \quad 6.0239679554$

C $-0.3425270884-8.3800563134 \quad 3.1856828849$

O $1.1815563653-7.3100832391 \quad 1.6608907059$

H -1.682580697 -9.1230827291 4.6911692876

H $1.0745186026-8.2124880027 \quad 1.2654654565$

C $-0.1453879401 \quad 6.7540125353 \quad 5.7121441117$

C $0.6761139877 \quad 5.7975001445 .0706329395$

C $0.7416849585 \quad 5.7736020627 \quad 3.672121342$

C $0.0049541855 \quad 6.6741946282 \quad 2.9131410835$

C $-0.806165802 \quad 7.6294579611 \quad 3.5479068949$

C $-0.87330791927 .6601029242 \quad 4.9268512054$

$\begin{array}{lllll}\text { O } & 1.3980289358 & 4.9073770184 & 5.7565683988\end{array}$

H $1.2056179247 \quad 5.0429334978 \quad 6.7177064008$

H - $1.5046637865 \quad 8.3921187502 \quad 5.4234497787$

H - $-1.377285091 \quad 8.33048219282 .9494157102$

H $1.3689590367 \quad 5.0287887976 \quad 3.194303982$

C $0.0479390685 \quad 6.6308405731 \quad 1.4213699159$

$\begin{array}{llll}\text { C } & 0.8497078065 & 7.5451940798 & 0.7179898534\end{array}$

C $-0.7492287697 \quad 5.7049510192 \quad 0.7266111528$

C $0.83529151597 .5513169414-0.7173155838$

C $1.6956895304 \quad 8.4825132687 \quad 1.3964717347$

C $-0.76505142535 .7118763497-0.7093878418$

Page: S78 
$\begin{array}{llll}\text { C } & -1.5764775471 & 4.7572053198 & 1.4140780957\end{array}$

C $0.0182362115 \quad 6.6437880036-1.4125048364$

C $1.66998866458 .4930209882-1.4037708129$

C 2.47140958029 .36296395990 .7043130699

H $1.7149216176 \quad 8.47537047292 .4806453867$

C - $-1.6100285953 \quad 4.7721871419-1.3864261099$

H $-1.5690595017 \quad 4.7489362801 \quad 2.4981229925$

C $-2.3570821605 \quad 3.8749639014 \quad 0.7300543572$

C $2.4586984693 \quad 9.3678846518-0.7191660364$

H $1.67015589128 .494175845-2.4880900079$

H $3.1086168346 \quad 10.0614417374 \quad 1.2370606044$

C $-2.3745666295 \quad 3.8831093878-0.6930711547$

H - $1.6298234053 \quad 4.7754576936-2.4702730785$

H -2.9718573498 $3.1621617234 \quad 1.2699632842$

H $3.086847796510 .0696669316-1.258294475$

H -3.0031717451 $3.1769467845-1.2257368361$

C $-0.05542336 .701113086-2.9025026673$

C $0.63400967095 .7827390033-3.6844045401$

C $-0.84872951737 .6872288762-3.5124233654$

C $0.5381011128 \quad 5.8191194191-5.0809391221$

H $1.24643780545 .0136436729-3.2261226872$

C $-0.94604303367 .7303808168-4.8892234455$

H $-1.3832227748 .4018491948-2.8964086275$

C $-0.26561362616 .8075078181-5.6970998602$

$\begin{array}{lllll}\text { O } & 1.2122740716 & 4.9095227117 & -5.7893532998\end{array}$

H - $1.56474129578 .4857729344-5.3663706328$

H $1.0027326825 .0615928041-6.7457427917$

C $0.0502576708 \quad 2.6205108547-9.9058333383$

H $0.37668626982 .5453138944-10.9500533896$

C $-0.0222020947 \quad 1.3794046547-9.155083538$

C $-0.3455444737 \quad 1.3742604596-7.776369776$

C $-0.36530861810 .1603962191-7.0800972296$

C $-0.090971232-1.0381668949-7.7282175839$

C $0.2132739942-1.036605458-9.1000667293$

C $0.253008103 \quad 0.1592913766-9.7903889165$

N $-0.23387529763 .7461380286-9.3552749878$

O $-0.626016588 \quad 2.4952481774-7.1074675685$

H $-0.55419690173 .2483259683-7.7519214852$

H $0.49943600660 .1658455679-10.8488666515$

H $0.4261547551-1.9731331959-9.6036351956$

H $-0.59987911050 .1756522565-6.0210827442$

C $-0.1082562871-2.3211651712-6.9667017899$

C $-1.3267025867-2.8561293798-6.5110026662$

C $1.100366117-2.9928198164-6.7067806165$

C $-1.3340828815-4.0803718228-5.760083435$

C $-2.581520519-2.2173346821-6.7825811635$

C $1.0886426079-4.2377774704-5.9911567775$

C $2.3644305235-2.4602704873-7.1253315988$

C $-0.1278317854-4.7614292008-5.516201721$

C $-2.5884275758-4.5670445117-5.2639914511$

C $-3.7531148496-2.7281038243-6.3114619066$

H -2.585997074 -1.3090888461 -7.3738627507

C $2.3347607808-4.9189881064-5.7915479947$
H $2.3840300206-1.50265298-7.6323973887$

C $3.5273122447-3.1306496665-6.8937559542$

C $-3.7552636916-3.9155766052-5.5276828486$

H -2.5956167077 -5.4710596695 -4.6660073977

H $-4.690502394-2.2264802132-6.5290582462$

C $3.5105865785-4.3877767918-6.2280733514$

H $2.3304615864-5.8740362603-5.2795819805$

H $4.4723397875-2.7066131703-7.2174098123$

H $-4.6925303498-4.3015743124-5.1401119329$

H $4.4412421012-4.9212294344-6.0640059271$

C $-0.1367715512-6.0389080503-4.7453363137$

C $0.3931494973-6.074319709-3.4610113796$

C $-0.6722177076-7.2081151227-5.3116886017$

C $0.4130663398-7.2641423657-2.7257471951$

H $0.809742548-5.1803984813-3.0093605902$

C $-0.6710351762-8.3832646833-4.5844308566$

H -1.08553945 $-7.1787224577-6.3138278995$

C $-0.1310285536-8.4418533301-3.290899893$

O $0.9469650646-7.2459610319-1.502561151$

H - $-1.0876148312-9.2887591158-5.0178388898$

C $-0.1395071892-9.6953377055-2.5560535286$

H $0.8746291254-8.165432054-1.1382289131$

H -0.6304578385 - $10.546486261-3.0431651949$

N $0.3890552409-9.7957434886-1.3886565291$

\section{Macrocycle 1 - Conformer D}

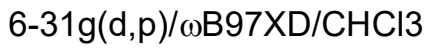

C $-4.5203148042-0.5367874431 \quad 6.0024165814$

$\begin{array}{llll}\text { C }-3.350424024 & 0.1946881988 & 6.1651780695\end{array}$

$\begin{array}{llll}C & -2.646502384 & 0.1617778732 & 7.3740792382\end{array}$

C -3.1412042093 $-0.6217409144 \quad 8.4451267776$

C $-4.3226576346-1.3549138226 \quad 8.2589868288$

C $-5.0092675282-1.3210680816 \quad 7.0602614168$

C $-2.4432067206-0.6782751403 \quad 9.717749053$

H $-2.8751561805-1.318711884610 .4967896565$

C $-0.6978865017-0.033086232 \quad 11.1495431951$

C $-1.3888095096-0.0371022661 \quad 12.3705952808$

H $-2.4717171256-0.0217787023 \quad 12.3561421429$

C $-0.7074872559-0.0154520325 \quad 13.5778396524$

C $0.70748725590 .0154520325 \quad 13.5778396524$

C $1.38880950960 .0371022661 \quad 12.3705952808$

H $2.47171712560 .0217787023 \quad 12.356142143$

$\begin{array}{llll}\text { C } & 0.6978865017 & 0.033086232 & 11.1495431951\end{array}$

C $2.4432067206 \quad 0.6782751403 \quad 9.717749053$

H $2.8751561805 \quad 1.318711884610 .4967896565$

C $3.1412042093 \quad 0.6217409144 \quad 8.4451267776$

C $2.646502384-0.1617778732 \quad 7.3740792382$

C $3.350424024-0.1946881988 \quad 6.1651780695$

C $4.52031480420 .5367874431 \quad 6.0024165814$

C $5.0092675282 \quad 1.3210680816 \quad 7.0602614168$

C $4.3226576346 \quad 1.3549138226 \quad 8.2589868288$

Page: S79 
N - $-1.3595540371 \quad-0.01554024789 .9104094221$

N $1.3595540371 \quad 0.0155402478 \quad 9.9104094221$

$\begin{array}{lllll}\text { O } & -1.5246805445 & 0.8784851826 & 7.4752354256\end{array}$

H $-1.1590292249 \quad 0.7244816723 \quad 8.3861204965$

O $1.5246805445 \quad-0.8784851826 \quad 7.4752354256$

H $1.1590292249 \quad-0.7244816723 \quad 8.3861204965$

O $1.2919380592 \quad 0.0163207849 \quad 14.797990073$

O $-1.2919380592-0.0163207849 \quad 14.797990073$

C -2.7043080622 $-0.0675922909 \quad 14.8509562718$

H $-3.1557658915 \quad 0.8126704453 \quad 14.3783075965$

H -3.0903452476 $-0.9747436157 \quad 14.3710979779$

H -2.9654435066 $-0.0806018757 \quad 15.9084094658$

C $2.7043080622 \quad 0.0675922909 \quad 14.8509562718$

H $3.1557658915 \quad-0.8126704453 \quad 14.3783075965$

H $3.09034524760 .9747436157 \quad 14.3710979779$

H $2.96544350660 .0806018757 \quad 15.9084094658$

H $4.696339318 \quad 1.95983163899 .0809366441$

H $5.9218174754 \quad 1.8918608034 \quad 6.9284699833$

H -4.696339318 -1.95983163899 .0809366441$

H -5.9218174754 -1.8918608034 6.9284699833

H $2.9592570331-0.7999757983 \quad 5.3545029339$

H $-2.9592570331 \quad 0.7999757983 \quad 5.3545029339$

C -5.2528895159 $-0.4847804877 \quad 4.7030674317$

C -4.7677320931 $-1.2007142316 \quad 3.5945408237$

C $-6.4228029174 \quad 0.2869157485 \quad 4.5920105602$

C $-3.5890531122-2.0128591423 \quad 3.6753350571$

C $-6.9356308488 \quad 1.0455420089 \quad 5.6951120643$

C -3.1280941918 $-2.6978399916 \quad 2.5916821954$

H $-3.0619333112-2.0739391094 .6206233945$

C -8.0693745879 $1.7912762959 \quad 5.573728662$

H $-6.400352914 \quad 1.0201152238 \quad 6.6376124901$

H - $2.2324407272 \quad-3.30483221612 .6744415223$

H $-8.4390661206 \quad 2.3593009492 \quad 6.4213337697$

C $5.25288951590 .4847804877 \quad 4.7030674317$

C $6.4228029174-0.28691574854 .5920105602$

C $4.7677320931 \quad 1.2007142316 \quad 3.5945408237$

C $7.1251574143-0.3433655596 \quad 3.3414241954$

C $6.9356308488-1.04554200895 .6951120643$

C $5.4664840121 \quad 1.1365008421 \quad 2.3419039384$

C $3.5890531122 \quad 2.0128591423 \quad 3.6753350571$

C $6.6356180512 \quad 0.3658802018 \quad 2.2323717456$

C $8.31425927-1.1396353215 \quad 3.2597266515$

C $8.0693745879-1.79127629595 .573728662$

H 6.400352914 -1.0201152238 6.6376124901

C $4.9440061871 \quad 1.8716513378 \quad 1.2278337494$

H 3.06193331122 .0739391094 .6206233945

C $3.1280941918 \quad 2.6978399916 \quad 2.5916821954$

C $8.7724893845-1.8364013604 \quad 4.3368766163$

H $8.8470183404-1.1826186463 \quad 2.3162361815$

H $8.4390661206-2.35930094926 .4213337697$

C $3.8142304607 \quad 2.6233344623 \quad 1.346741214$

H $5.465456077 \quad 1.817945191 \quad 0.2786041753$

H $2.2324407272 \quad 3.30483221612 .6744415223$
H $9.6740675276-2.4347333755 \quad 4.2541006249$

H $3.4327764404 \quad 3.1704846105 \quad 0.4907916101$

C $7.3578923783 \quad 0.2922331818 \quad 0.9276008747$

C $7.0090274269-0.68306539810 .0020918946$

C $8.3869498677 \quad 1.2017134593 \quad 0.6357602577$

C $7.6713841939-0.771546587-1.2270013938$

H $6.2150450982-1.3904291116 \quad 0.2158587615$

C $9.047519612 \quad 1.1180305078-0.5755175$

H $8.6550447672 \quad 1.9610100556 \quad 1.3619953712$

C $8.71003477250 .1423747369-1.5251299084$

O $7.3013472671-1.7309418747$-2.07981283

H $9.8452951767 \quad 1.8186116878-0.8075987994$

C $9.42896028810 .0792172213-2.7866145078$

H $7.8598192153-1.6334887361-2.8922797519$

H $10.2503295423 \quad 0.792262038-2.9295750256$

N $9.114689951-0.7682630286-3.6990373357$

C $9.8771263774-0.8723453843-4.875319447$

C $11.2792908012-0.9109025561-4.8326014955$

H $11.76811175-0.8510798322-3.8679048557$

C $12.0251695258-1.071688522-5.9895270335$

O $13.3744052685-1.1368622043-6.0396268715$

C $14.084568782-1.0307681863-4.8206478057$

H $13.8949538769-0.0691171357-4.3294308026$

H $13.82638007-1.8457569275-4.134490999$

H $15.1400383938-1.100160585$-5.0807071135

C $-7.3578923783 \quad-0.2922331818 \quad 0.9276008747$

C -7.00902742690 .68306539810 .0020918946$

C $-7.67138419390 .771546587-1.2270013938$

C $-8.7100347725-0.1423747369-1.5251299084$

C $-9.047519612-1.1180305078-0.5755175$

C $-8.3869498677 \quad-1.2017134593 \quad 0.6357602577$

C $-9.4289602881-0.0792172213-2.7866145078$

H -10.2503295423 $-0.792262038-2.9295750256$

C $-9.8771263774 \quad 0.8723453843 \quad-4.875319447$

C -11.2792908012 $0.9109025561-4.8326014955$

H -11.76811175 0.8510798322 -3.8679048557

C $-12.0251695258 \quad 1.071688522-5.9895270335$

C $-11.3594445866 \quad 1.2110617541-7.2316272673$

C $-9.9759879283 \quad 1.1677870316-7.2720821425$

H $-9.4612902467 \quad 1.3057456548$-8.2147144733

C $-9.21883501540 .9850122672-6.1025892666$

C $-7.1551266057 \quad 0.4846370725-7.1121147945$

H $-7.6511468957 \quad 0.1343938846-8.0252731885$

C $-5.70376848320 .4145879073 \quad-7.0951563617$

C $-4.96710538520 .724832945-5.9270780333$

C $-3.57217442020 .6147585478-5.9442157799$

C - $-2.90301218170 .2167933065-7.0954048441$

C $-3.6312717788-0.0861545831-8.2577696356$

C $-5.0099121913 \quad 0.0076045353-8.244307918$

N -9.114689951 $0.7682630286-3.6990373357$

N -7.8175623298 $0.909181623 \quad-6.0964304873$

$\begin{array}{lllll}0 & -7.3013472671 & 1.7309418747 & -2.07981283\end{array}$

H $-7.85981921531 .6334887361-2.8922797519$

Page: S80 
O $-5.5593904612 \quad 1.1107095126-4.7943699431$ H $-6.5364504217 \quad 1.1318114135-4.9636063039$

O $-12.1624946374 \quad 1.4002990018-8.3042512822$

O $-13.37440526851 .1368622043-6.0396268715$

C $-14.084568782 \quad 1.0307681863-4.8206478057$

H -13.8949538769 $0.0691171357-4.3294308027$

H $-13.82638007 \quad 1.8457569275-4.134490999$

H -15.1400383938 1.100160585 -5.0807071135

C -11.5461616181 $1.5682505236-9.565813654$

H -10.9014438531 2.4548894764 -9.5823516488

H -10.957000535 $0.686446295-9.8446026492$

H $-5.5780927207-0.2327049716-9.139106883$

H -3.1065877646 $-0.3981945239-9.1540498989$

H $-9.8452951767-1.8186116878-0.8075987994$

H -8.6550447672 -1.96101005561 .3619953712$

H $-3.0235167326 \quad 0.849510954 \quad-5.0383382908$

H $-6.2150450982 \quad 1.3904291116 \quad 0.2158587615$

C $-6.6356180512-0.3658802018 \quad 2.2323717456$

C $-5.4664840121-1.1365008421 \quad 2.3419039384$

C -7.1251574143 $0.3433655596 \quad 3.3414241954$

C $-4.9440061871 \quad-1.8716513378 \quad 1.2278337494$

C $-8.31425927 \quad 1.1396353215 \quad 3.2597266515$

C $-3.8142304607-2.6233344623 \quad 1.346741214$

H $-5.465456077-1.8179451910 .2786041753$

C $-8.7724893845 \quad 1.8364013604 \quad 4.3368766163$

H $-8.8470183404 \quad 1.1826186463 \quad 2.3162361815$

H -3.4327764404 -3.17048461050 .4907916101$

H $-9.6740675276 \quad 2.4347333755 \quad 4.2541006249$

C $-1.4146589027 \quad 0.1073875942-7.0933455063$

C $-0.8077622262-1.1611402138-7.0854402245$

C $-0.6239789976 \quad 1.2702164583-7.1000683595$

C $0.6239789976-1.2702164583-7.1000683595$

C $-1.5824112568-2.3672379751-7.049887495$

C $0.8077622262 \quad 1.1611402138-7.0854402245$

C $-1.2068651735 \quad 2.5798621633-7.13191551$

C $1.4146589027-0.1073875942-7.0933455063$

C $1.2068651735-2.5798621633-7.13191551$

C $-0.9860450204-3.5918682535-7.0630695743$

H -2.6628909019 -2.2907395306 -7.0091308156

C $1.5824112568 \quad 2.3672379751 \quad-7.049887495$

H $-2.28651766172 .6685389876-7.1663117233$

C $-0.43181159043 .6999154575-7.115731845$

C $0.4318115904-3.6999154575-7.115731845$

H $2.2865176617-2.6685389876-7.1663117233$

H -1.5921310703 -4.4915772008 -7.0332976458

C $0.9860450205 \quad 3.5918682535-7.0630695743$

H $2.66289090192 .2907395306-7.0091308156$

H $-0.8949831734 \quad 4.681024623 \quad-7.1386806023$

H $0.8949831734-4.681024623 \quad-7.1386806023$

H $1.5921310704 \quad 4.4915772008-7.0332976458$

C $2.9030121817-0.2167933065-7.0954048441$

C $3.5721744202-0.6147585478-5.9442157799$

C $3.6312717788 \quad 0.0861545831 \quad-8.2577696356$
C $4.9671053852-0.724832945-5.9270780333$

H $3.0235167326-0.849510954-5.0383382908$

C $5.0099121913-0.0076045353-8.244307918$

H $3.10658776460 .3981945239-9.1540498989$

C $5.7037684832-0.4145879073-7.0951563617$

O $5.5593904612-1.1107095126-4.7943699431$

H $5.5780927207 \quad 0.2327049716$-9.139106883

C $7.1551266057-0.4846370725-7.1121147945$

H $6.5364504217-1.1318114135$-4.9636063039

H $7.6511468957-0.1343938846-8.0252731885$

N $7.8175623298-0.909181623-6.0964304873$

C $9.2188350154-0.9850122672-6.1025892666$

C $9.9759879283-1.1677870316-7.2720821425$

H $9.4612902467-1.3057456548$-8.2147144733

C $11.3594445866-1.2110617541-7.2316272672$

O $12.1624946374-1.4002990018-8.3042512822$

C $11.5461616181-1.5682505236-9.565813654$

H $10.9014438531-2.4548894764-9.5823516488$

H $10.957000535-0.686446295$-9.8446026492

H 12.3566575417 -1.6999454487 -10.2815965863

H -12.3566575417 1.6999454487 - 10.2815965863

\section{Macrocycle 1 - Conformer E} $6-31 \mathrm{~g}(\mathrm{~d}, \mathrm{p}) / \omega \mathrm{B} 97 \mathrm{XD} / \mathrm{CHCl} 3$

C $-9.2275498276 \quad 6.2937125147 \quad 0.272972723$

C -9.9007406865 7.52224162840 .3525880888

H $-9.3168693133 \quad 8.42678526640 .471311074$

C $-11.285188332 \quad 7.5824353266 \quad 0.3207110826$

C $-12.0298587998 \quad 6.3844670493 \quad 0.2022642085$

C -11.3637719051 $5.1714820276 \quad 0.1400498692$

H -11.9262157491 4.25563490680 .0071420726

C - $-9.9619521126 \quad 5.1070870337 \quad 0.2001744514$

C $-9.7404255743 \quad 2.788715305 \quad 0.5307514247$

H $-10.7298856018 \quad 2.7282320893 \quad 0.9999501881$

C -8.9968301629 $1.5466918996 \quad 0.4150010016$

C $-7.6784972918 \quad 1.5251443358-0.1012189805$

C $-6.98900335310 .3093264406-0.1743192631$

C $-7.5888945462 \quad-0.8759994871 \quad 0.2343793202$

C $-8.9008419213 \quad-0.8575113358 \quad 0.7376322754$

C $-9.5815172181 \quad 0.34080836640 .8295040473$

N -9.24722002653 .90081064420 .1174401453$

O $-7.06089967392 .6323387355-0.5206529426$

H -7.6920431251 $3.3883581164-0.3930712579$

$\begin{array}{lllll}\text { O } & -13.3735801975 & 6.5357637511 & 0.15125374\end{array}$

$\begin{array}{lllll}\text { O } & -12.014204824 & 8.7187945273 & 0.3934899495\end{array}$

C -11.3150322403 $9.944662557 \quad 0.4906212993$

H -10.7134616612 $9.9916379541 \quad 1.4058979618$

H -10.6663077555 $10.1052643899-0.3785260131$

H -12.0761594541 10.72330196610 .5207148127

C -14.1637922335 $5.3670193493 \quad 0.0547272767$

H $-13.95827643914 .8189299299-0.8723753392$

Page: S81 
H -14.0025511603 4.70262482490 .9119846144

H - $15.1997784771 \quad 5.70364434950 .0500600622$

H $-10.5940126787 \quad 0.3601234733 \quad 1.2240403222$

H -9.3663516046 -1.7837631219 1.0559147337

H $-5.9763984756 \quad 0.311682933-0.5633866153$

C $-6.8478456665-2.1675022377 \quad 0.1384556515$

C $-6.5930522794-2.7423011325-1.1200706879$

C $-6.4191428216-2.8150762714 \quad 1.311404885$

C $-5.8851561976-3.9889891267-1.2062775215$

C $-7.0348201373-2.1261125685-2.3373365039$

C $-5.74686161-4.0813018344 \quad 1.2267220899$

C $-6.6253943331-2.2391727342 \quad 2.6084214298$

C $-5.483696341-4.6514531808-0.0320418013$

C $-5.5978884083-4.5204726586-2.5068610167$

C $-6.758824009-2.6780374246-3.5517031335$

H $-7.5963169771-1.2011361458-2.279402655$

$\begin{array}{llll}\text { C }-5.3754033245 & -4.736836818 & 2.4468764593\end{array}$

H -7.0990283166 -1.2666795582 .6766739961$

C $-6.2344417603-2.8866712467 \quad 3.7412458444$

C $-6.0159822488-3.8882570724-3.6385924769$

H -5.0322075736 $-5.4420611479-2.5796044411$

H -7.1018005315 $-2.1919815082-4.4593292707$

C $-5.6113496886-4.1630841552 \quad 3.6595498533$

H $-4.8949741842-5.7066287895 \quad 2.3914521432$

H $-6.3978518979-2.4297999307 \quad 4.7119065943$

H $-5.7837951202-4.3074088333-4.6122606352$

H $-5.319370196-4.67745246354 .5693833848$

C $-4.7909949712-5.9697276259-0.1254386925$

C $-3.441557462-6.07697187660 .1893771098$

C $-5.5059113542-7.1089632671-0.5325422288$

C $-2.782888727 \quad-7.30973303430 .1151756639$

H $-2.875689553-5.20645511270 .5036329887$

C $-4.8591023326-8.325945204-0.624387961$

H $-6.5586206242-7.0222806201-0.7779758218$

C $-3.4995153765-8.4567572121-0.3042672691$

O $-1.4887788971-7.35914671790 .4406002572$

H -5.4073829238 $-9.2078370168-0.9451849824$

C $-2.8499174868-9.7506781318-0.4181683188$

H $-1.1918758389-8.300196657 \quad 0.3271592615$

H -3.4588537807 -10.5742142559 -0.810208937

N -1.6174419927 $-9.9070081836-0.0903915065$

C $-0.9753359084-11.153290999-0.1729867853$

C - $1.6527323917-12.376376439-0.0379460952$

H $-2.7180680839-12.3680494563 \quad 0.1555669388$

C $-0.976143832-13.5832223411-0.1043252003$

O $-1.5505365657-14.80267049820 .0155803642$

$\begin{array}{llll}\text { C }-2.9524386177 & -14.8551280481 & 0.1932796795\end{array}$

H -3.257646643 $-14.3644128884 \quad 1.1250821779$

H -3.4804894379 -14.3933279555 -0.6494946392

H -3.2100302385 $-15.9123344305 \quad 0.243761736$

C $9.33001288575 .9681039364-0.6920416106$

C $10.06845301667 .1611464964-0.6837986757$

H $9.5434430598 \quad 8.0981740832-0.5438798652$
C $11.449212247 \quad 7.1484370057-0.8070796458$

C $12.12430380845 .9118297328-0.9418467288$

C $11.3954339076 \quad 4.732782779-0.9302766599$

H $11.8959184046 \quad 3.7823513417-1.0692566135$

C $9.9999096025 \quad 4.7455342317-0.7846502846$

C $9.65645792342 .4881139752-0.2517749764$

H 10.61741816642 .44788583810 .2759891622

C $8.87165165641 .2666415971-0.2858346761$

C $7.59933622531 .2290056651-0.9064507326$

C $6.86911052850 .03483685-0.904034966$

C $7.3757245801-1.1068244682-0.2955888978$

C $8.637923958-1.07233983730 .3199646085$

C $9.3657722037 \quad 0.10178439540 .319661794$

N $9.23031309743 .5698667912-0.798229808$

$\begin{array}{llll}\text { O } & 7.0633001502 & 2.3005986429 & -1.49633853\end{array}$

H $7.70482047753 .0499792808-1.384573001$

O $13.4678086149 \quad 5.9915379806-1.0792823404$

O $12.2378316814 \quad 8.2476699109-0.8064232253$

C $11.60772300929 .5090445832-0.6964039532$

H $10.91205607699 .6828005002-1.5259077794$

H $11.0702867717 \quad 9.60752676880 .2541295579$

H $12.406418013 \quad 10.2487331304-0.7353960988$

C $14.19067610314 .7813196882-1.1933547395$

H $14.0519044684 \quad 4.1471435447-0.3097247022$

H $13.8987253213 \quad 4.2222829883-2.0901986404$

H 10.34060624960 .13588506280 .7989457297

H $9.028445394-1.96621208980 .7936538245$

H $5.8934801167 \quad 0.0229684023-1.3779903555$

C $6.5779187475-2.3682269584-0.2796934824$

C $6.905141918-3.4148997077-1.1587910856$

C $5.5148789559-2.51141566510 .6293149877$

C $6.1599802452-4.6411375294-1.1178930017$

C $7.9653337624-3.2940196086-2.1161543175$

C $4.7665627672 \quad-3.7363497294 \quad 0.6656673214$

C $5.1597116156-1.46912198961 .5473936518$

C $5.1040618218-4.7873981265-0.2034220138$

C $6.5174262349-5.6894507322-2.0276781271$

C $8.271871549-4.3159584128-2.963475668$

H $8.5229052808-2.3651891854-2.1607230754$

C $3.6941562177-3.8550852719 \quad 1.6094953627$

H $5.7254670942-0.54464925751 .5305562822$

C $4.130797231-1.62314133762 .4268349682$

C $7.5374122183-5.5345417162-2.9172790137$

H $5.953505678-6.6152958631-2.0004382471$

H $9.0763640261-4.2022049263-3.6829195785$

C $3.3843681611-2.8346573057 \quad 2.4570285195$

H $3.124574804-4.77720766631 .6370819427$

H $3.8767833713-0.8197199993 .1105922631$

H $7.7904777187-6.3392355046-3.6000281245$

H $2.5661942152-2.9430792863 .1615605042$

C $4.3510711774-6.0749256918-0.137237771$

C $3.1579774875-6.2258000288-0.8323742451$

C $4.8496095876-7.13172744710 .6419360064$

Page: S82 
C $2.4357396545-7.4228165546-0.7604773421$

H $2.7611477974-5.415218163-1.433992474$

C $4.1428106343 \quad-8.3162546498 \quad 0.7166775266$

H $5.7816402266-7.0071225788 \quad 1.1819025088$

C $2.9336430738-8.4884659672 \quad 0.0268145757$

O $1.2914126943-7.5173204271-1.4424187452$

H $4.519435893-9.1357343921 \quad 1.3231211101$

C $2.206317527 \quad-9.7393905171 \quad 0.1475784497$

H $0.9045459719-8.4098172573-1.2508745673$

H $2.6496564376-10.51235744610 .7876277395$

N $1.0831613391-9.9260755159$-0.4479550912

C $0.4136578589-11.1573902037-0.3263738765$

C $1.0990090981-12.3788202598-0.4098597782$

H $2.1666956927-12.3625820958-0.5912291656$

C $0.4253438735-13.5856184391-0.3042484708$

O $1.0038974073-14.8054692789-0.3765274075$

C $2.4062559034-14.859781231-0.5543781149$

H 2.7082998168 -14.3984634729 -1.5018984117

H $2.9336795944-14.369415903 \quad 0.2723035964$

H $2.6664748183-15.9173755809-0.5706498247$

H $15.23970532855 .0638848771-1.2724154317$

C -7.1064566624 $7.055408279-0.338228785$

H $-7.5633676825 \quad 7.8279693588-0.9691499626$

C $-5.65571884117 .0077003477 \quad-0.303515068$

C $-4.9713870784 \quad 6.0285202645 \quad 0.4556820368$

C $-3.5718298412 \quad 5.9977791876 \quad 0.4359023525$

C $-2.8533427808 \quad 6.913213427-0.3226975615$

C -3.529667564 $7.8906955756-1.071050204$

C $-4.91033833267 .9275795913-1.0557002565$

N -7.8237396034 $6.2149042386 \quad 0.3175439986$

O $-5.6177713556 \quad 5.1221669877 \quad 1.1933434438$

H $-6.5894004897 \quad 5.27028680351 .0609364313$

H $-5.43980770368 .6758218158-1.6395624532$

H -2.9625216695 8.6027701564 -1.6602112567

H $-3.0612353958 \quad 5.2352379894 \quad 1.0141198712$

C $-1.3621284141 \quad 6.85575417-0.3662312571$

C $-0.7244998776 \quad 5.9557843853-1.2371620636$

C $-0.6039566987 \quad 7.7216124393 \quad 0.4390928383$

C $0.70904801135 .934272683-1.3179426673$

C $-1.4693629906 \quad 5.0599009661 \quad-2.0725040038$

C $0.8292177699 \quad 7.6979378538 \quad 0.3615027821$

C $-1.2239787173 \quad 8.6352928528 \quad 1.3531036798$

C $1.4673136098 \quad 6.8111741302-0.52248841$

C $1.3262896925 .0218322269-2.2355453349$

C $-0.84092483834 .2017766841-2.9235531594$

H -2.5518556252 $5.0720570846-2.0145497904$

C $1.572177358 \quad 8.5854698199 \quad 1.2072518975$

H $-2.3063440167 \quad 8.6508125569 \quad 1.4176833951$

C $-0.4792138101 \quad 9.4659112806 \quad 2.1349623722$

C $0.5797541785 \quad 4.1834679312-3.0072608414$

H $2.40791188115 .0053520978-2.3055491888$

H -1.4234915205 $3.5287813162-3.5442072095$

C $0.9422198236 \quad 9.4394987874 \quad 2.061650817$
H $2.6552534528 \quad 8.5627648513 \quad 1.1611496463$

H $-0.9678505523 \quad 10.1479354342 .8232652139$

H $1.0677282747 \quad 3.4978303065$-3.6922957687

H $1.5238765536 \quad 10.10063861832 .6959142289$

C $2.95540952826 .8199628849-0.6390508666$

C $3.71468695415 .8302697896-0.0274138663$

C $3.58729450297 .8283915705-1.3854805512$

C $5.10894786815 .8178437732 \quad-0.1524368439$

H $3.23871255795 .0430442604 \quad 0.5473748678$

C $4.96287553997 .8244352489-1.5114077653$

H $2.989644804 \quad 8.5984467503 \quad-1.8605761513$

C $5.7480186733 \quad 6.8320152735 \quad-0.9063516331$

O $5.792688848 \quad 4.8393297395 \quad 0.4462562328$

H $5.4566434565 \quad 8.5986291785-2.0927372729$

C $7.18998622636 .8453447673-1.0782060766$

H $6.7524767264 \quad 4.97688045390 .2314290473$

H $7.61007016387 .6438755684-1.7022888723$

N $7.933218445 \quad 5.9460635012-0.5404153064$

\section{Macrocycle 1 - Conformer $\mathbf{H}$}

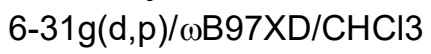

C $-4.4966613447 \quad 0.515683191 \quad 5.9914189779$

C $-3.3863674918-0.3029261433 \quad 6.1566993919$

C $-2.6781804112 \quad-0.3117070104 \quad 7.3637057552$

C $-3.1052661423 \quad 0.518093537 \quad 8.4273978845$

C $-4.2352861742 \quad 1.3281782289 \quad 8.2433961096$

C $-4.9280848416 \quad 1.3344844718 \quad 7.0478442573$

C $-2.3774507532 \quad 0.567231486 \quad 9.6842872673$

H $-2.7629816673 \quad 1.2459976372 \quad 10.4551878553$

C - $-0.6415335907-0.0739255866 \quad 11.109706688$

C - $-1.3286456688-0.0980513899 \quad 12.3327054948$

H $-2.4079610238-0.1885566078 \quad 12.3177244627$

C $-0.6450203448-0.0503121795 \quad 13.5379518416$

C 0.76830700250 .024191395613 .5336683492

C $1.4459428595 \quad 0.0466400311 \quad 12.3244907256$

H $2.5287447793 \quad 0.0675989517 \quad 12.3039041653$

C $0.7529296623 \quad-0.0010170303 \quad 11.105185483$

C $2.4285369866 \quad 0.7774267425 \quad 9.6688814341$

H $2.7749907504 \quad 1.4787499537 \quad 10.438156483$

C $3.1499928915 \quad 0.7728211832 \quad 8.4071394976$

C $2.7698412091-0.08774859997 .3497379645$

C $3.4837697071-0.0567566458 \quad 6.1470756579$

C $4.5535792522 \quad 0.813319388 \quad 5.97735783$

C $4.9319225283 \quad 1.6710060842 \quad 7.0231393779$

C $4.2341258214 \quad 1.6420724582 \quad 8.215969192$

N -1.3144270901 -0.12743044279 .8768269448$

N $1.4173438446 \quad 0.0106457996 \quad 9.8675692357$

O $-1.6107942585-1.1076948282 \quad 7.4688443787$

H $-1.2175513635-0.9556310517 \quad 8.3656856839$

$\begin{array}{lllll}\text { O } & 1.7454044514 & -0.9372247084 & 7.4581293072\end{array}$

H $1.3493962738-0.80608327658 .3578010127$ 
O $1.3553737885 \quad 0.0467196918 \quad 14.752544568$ O $-1.2239373142-0.0904881101 \quad 14.7601155328$ C - $2.6333568002-0.1930501823 \quad 14.8173216337$ H -3.1176207596 $0.6670461312 \quad 14.3397749233$ H -2.98761112 $-1.1167918097 \quad 14.3449880555$ H -2.891127585 $-0.2085875214 \quad 15.8755722926$ C $2.76788887590 .0956838662 \quad 14.8014909633$ H $3.2164613926-0.7855469378 \quad 14.3280445386$ H $3.1544372357 \quad 1.001956888914 .320235114$ H $3.03201019280 .1094779094 \quad 15.8582043156$ H $4.5210687452 \quad 2.3049930915 \quad 9.0280077297$ H $5.767361509 \quad 2.3487664969 \quad 6.886643832$ H $-4.5590824852 \quad 1.9661090438 \quad 9.0615451081$ H $-5.7964251299 \quad 1.9701018247 \quad 6.9141065295$ H $3.1786035896-0.72154470865 .3461590303$ H $-3.0404173853-0.9372538427 \quad 5.3477275176$ C $-5.22138150390 .5444373887 \quad 4.6867167157$ C -6.4289248167 -0.15853380354 .5396021965$ C $-4.7003387486 \quad 1.2917350424 \quad 3.6160328912$ C $-6.9746949458-0.94901632525 .6035838723$ C $-3.4749501657 \quad 2.0266142327 \quad 3.7341265752$ C -8.1428844692 $-1.6324261144 \quad 5.4479128281$ H -6.434609034 -1.0003959315 6.5424400002 C -2.9856279859 $2.755785102 \quad 2.692723286$ H $-2.9348316349 \quad 1.9916232538 \quad 4.6733488948$ H $-8.5372199448 \quad-2.2278862388 \quad 6.2649785996$ H $-2.0539502153 \quad 3.3013605302 \quad 2.8024914439$ C $5.2920376842 \quad 0.8318949127 \quad 4.6804575619$ C $6.54082493390 .1948683018 \quad 4.5779295188$ C $4.7302419174 \quad 1.4755153922 \quad 3.5639449857$ C $7.2438448571 \quad 0.1987345825 \quad 3.3264629591$ C $7.1351600008-0.4859159356 \quad 5.6907773113$ C $5.4313310638 \quad 1.4733880377 \quad 2.3111277407$ C $3.4678853208 \quad 2.15124599013 .6363327052$ C $6.6776109021 \quad 0.8336227092 \quad 2.2087877621$ C $8.5117942103-0.4657063096 \quad 3.2523126034$ C $8.3433811297-1.1050330694 \quad 5.5767822953$ H $6.6013954689-0.5047695704 \quad 6.634345046$ C $4.8313135314 \quad 2.1345153118 \quad 1.1897116941$ H $2.9368196785 \quad 2.1630567974 \quad 4.581340338$ C $2.9338744757 \quad 2.7682784063 \quad 2.5454465454$ C $9.0446604746-1.09249033174 .3381053657$ H $9.0443707079-0.4655095827 \quad 2.3077614347$ H 8.7744802468 -1.6162886824 6.4314712419 C $3.6251737536 \quad 2.7577071663 \quad 1.3011995905$ H $5.3562468526 \quad 2.12932416690 .2409137081$ H $1.9755259199 \quad 3.2717493624 \quad 2.6217430657$ H $10.0053686227-1.5912626554 .2608828501$ H $3.1863572 \quad 3.2503576714 \quad 0.4396650888$ C 7.39775535630 .81393979890 .9009980961 C $7.1176553595-0.1869063071-0.0205312197$ C $8.3544335929 \quad 1.7970181278 \quad 0.6015824047$ C $7.7777882837-0.2289076019-1.2531591426$
H $6.3798707428-0.95102190120 .1992100473$ C $9.0127443564 \quad 1.7597709861 \quad-0.6133421806$ H $8.5695198393 \quad 2.5757500153 \quad 1.3248847013$ C $8.74358851890 .7594349783-1.5591733926$ O $7.4758431689-1.2159056368-2.1009815534$ H $9.7548093026 \quad 2.5173105312-0.8513006472$ C $9.45841173920 .7454502913 \quad-2.8244217477$ H 8.0217595978 -1.0803709517 -2.9166000151 H $10.22512570661 .5155670851-2.9744425746$ N $9.2009364418-0.1263706156-3.7316083822$ C $9.9613606791-0.1852885497-4.911948679$ C $11.3630470365-0.1245498588-4.8770882903$ H $11.8515578123-0.017935715-3.9163139437$ C $12.1119226032-0.2485485003-6.0363334394$ $\begin{array}{lllll}\text { O } & 13.4617418852 & -0.2185645567 & -6.0945668434\end{array}$ C $14.1697411535-0.0443758496-4.8820611767$ H $13.91486907590 .9084396474-4.4033693736$ H $13.9742409206-0.8655744228-4.1827541283$ H $15.2258939309-0.0423019003-5.1484495624$ C $-7.3813231877 \quad 0.7353235026 \quad 0.9425227407$ C $-6.9901101673-0.0263204109-0.1515160254$ C -7.6776258365 $0.0626136698-1.3675451084$ C $-8.78739670430 .9345297758-1.4762646446$ C $-9.1693615841 \quad 1.6897486905-0.3575993627$ C $-8.4840457528 \quad 1.5991617225 \quad 0.8383556627$ C $-9.5185411304 \quad 1.0711437541-2.7234560217$ H -10.3565584349 $1.7792334424-2.7336448892$ C $-9.92705922420 .5402969733-4.9620271613$ C $-11.32955130640 .5811777334-4.9575796791$ H -11.8482104452 $0.4934469927-4.0106904351$ C $-12.0459283745 \quad 0.6891317089-6.139507221$ C $-11.3496521914 \quad 0.760729698-7.3696550038$ C $-9.96531096390 .7035494799-7.3731993335$ H $-9.42452632190 .7997149311-8.3065106725$ C $-9.23998948240 .5688950528-6.1784368737$ C -7.1446295501 $0.0350825152-7.1000126972$ H $-7.6154579768-0.4250612012-7.9772963488$ C $-5.69288064120 .0368996066-7.0620194803$ C $-4.98885106890 .5516771388-5.9465486007$ C $-3.5895909473 \quad 0.5217357584 \quad-5.943862133$ C $-2.8860723437 \quad 0.0061051233-7.0258160326$ C $-3.5828240014-0.500227022-8.1358834048$

C $-4.9641528403-0.4855316419-8.1408059637$ N -9.1860691876 0.4096690368 -3.7736195048 N $-7.8362318378 \quad 0.5360066595 \quad-6.1399571692$ O $-7.2572332598-0.6841150811-2.3918596462$ H $-7.8355865578-0.4727022675$-3.1693724663 O $-5.6160493177 \quad 1.0666318355-4.8860057279$ H $-6.5918841305 \quad 0.9975053122-5.0586426655$ $\begin{array}{lllll}\text { O } & -12.1235046776 & 0.89014301 & -8.4721216867\end{array}$ $\begin{array}{lllll}\text { O } & -13.3946459087 & 0.7335482972 & -6.2273913789\end{array}$ C -14.1343165691 $0.6900618423-5.0224612809$ H $-13.9663903561 \quad-0.249195666$-4.482618418 
H -13.8839251077 $1.5338615403-4.368681198$

H -15.1826918807 $0.7562076806-5.3105897899$

C - $-11.47539908640 .9470654261-9.7277219621$

H -10.8207705913 $1.8234881708-9.8021632874$

H - $10.88953793690 .0398897082-9.9177309105$

H -5.5074062657 -0.8799302046 -8.995516387

H -3.0306835972 $-0.9031029047-8.9777674949$

H - $10.0201598817 \quad 2.3601606891-0.4460788093$

H -8.7852312007 2.19062256851 .6958732751

H -3.0651860467 $0.9141254238-5.0791471288$

H -6.1377176956 $-0.6938621276-0.0851422581$

$\begin{array}{llll}\text { C } & -6.625634915 & 0.6515300323 & 2.2270780574\end{array}$

C $-7.1402893428-0.10425926613 .2940033832$

C $-5.4119536351 \quad 1.3461848807 \quad 2.370079379$

C $-8.3628244339-0.84312025653 .1738878684$

C $-4.86355346892 .1334725514 \quad 1.3047758868$

$\begin{array}{llll}\text { C }-8.8485212626 & -1.5785001424 & 4.2128032474\end{array}$

H $-8.8984737868-0.8127465198 \quad 2.2316239094$

C -3.6914425642 $2.810436375 \quad 1.4581137264$

H $-5.39914656882 .1810971823 \quad 0.3634653082$

H -9.7743832193 -2.13322035924 .0998684132$

H $-3.2923496561 \quad 3.3974359474 \quad 0.6373404355$

C $-1.393917447-0.0089921611-7.0129318498$

C $-0.7088720326-1.2264176907-6.8509250008$

C $-0.6772738102 \quad 1.1902696008-7.1743115973$

C $0.7268285664-1.2491470641-6.8736310419$

C $-1.4070539693-2.4627257794-6.6505483882$

C $0.7586210301 \quad 1.171913195-7.163673123$

C $-1.3406211376 \quad 2.4471791881-7.3651100149$

C $1.4438788701-0.0486100268-7.0250725807$

C $1.3891055426-2.5152065006-6.7527799972$

C $-0.7360909302-3.6408748928-6.5191837395$

H - $2.4897228936-2.4468929967-6.600115668$

C $1.4561235865 \quad 2.4189214011-7.2855714474$

H -2.4237262027 2.463866158 -7.4004952299

C $-0.63724090813 .6062016788-7.497129752$

C $0.6850537602-3.668940495-6.5832963419$

H $2.4716914306-2.5426858624-6.7950709633$

H $-1.2848747427-4.564223426-6.3647302839$

C $0.7845791125 \quad 3.5934019043-7.4444512938$

H $2.53928834472 .4155032932-7.2460696517$

H -1.1609136604 $4.5460360149-7.6391016525$

H $1.207967439-4.6153618147-6.4916195762$

H $1.3335543547 \quad 4.5254014269-7.53214463$

C $2.9358356104-0.0674559191-7.0482611383$

C $3.6497841493-0.3108202969-5.8808359288$

$\begin{array}{llll}\text { C } 3.6231113528 & 0.1637674745 & -8.2515623408\end{array}$

C $5.049036103-0.3374485385-5.8874974137$

H $3.133805486-0.4893902831-4.9434516669$

C $5.00473708530 .1550524549-8.262483169$

H $3.06396205810 .3546903149-9.1609087661$

C $5.7436414585-0.0972784868-7.0971922751$

O $5.6844328985-0.5773079999-4.7377984328$
H $5.54038340780 .3412242342-9.1896619525$

C $7.195975216-0.0790305741-7.1434796519$

H $6.6574810166-0.564533332-4.9289751333$

H $7.6487247310 .2257173386-8.0944500361$

N $7.9020878576-0.3770791795-6.1124820866$

C $9.3050426486-0.3606425509-6.1331982431$

C $10.067710165-0.5074047043-7.3046186806$

H $9.5614845348-0.692808659-8.2435573587$

C $11.450618029-0.4528839537-7.2721804536$

O $12.2596127713-0.6001019485-8.3469229396$

C $11.6505639379-0.8296614091-9.6022978907$

H $11.0704313786-1.760001701-9.6025306198$

H $10.9989441880 .0040132298-9.8900280869$

H $12.4648417057-0.9139337132-10.3209276194$

H -12.2671047532 $1.0267466106-10.4716536786$

\section{Macrocycle 1 - Conformer I}

$6-31 \mathrm{~g}(\mathrm{~d}, \mathrm{p}) / \omega \mathrm{B} 97 \mathrm{XD} / \mathrm{CHCl} 3$

$\begin{array}{llll}\text { C } & 2.3019450489 & -7.1580294739 & 0.2666729661\end{array}$

C $3.071478955-6.354475915-0.5653013222$

C $4.4677904284-6.4460389713-0.5557677311$

C $5.0987848259-7.3720313020 .3086414543$

C $4.3027442136-8.177390319 \quad 1.136293745$

C $2.9241449105-8.0803145185 \quad 1.1235269999$

C $6.5465998546 \quad-7.48768899830 .3617208203$

H $6.9608287456-8.22575601051 .0597774048$

C $8.7055236893-6.9087564318-0.3208885083$

C $9.3036014953-8.1783172955-0.3180533101$

H $8.6645643155-9.0516087233-0.3664862671$

C $10.6824839179-8.3197200064-0.2990567218$

C $11.4998944959-7.164317868-0.2865654026$

C $10.9081600351-5.9111725922-0.2896536673$

H $11.5205530953-5.0182607421-0.3163976198$

C $9.5118092448-5.7685233329-0.3028810972$

C $9.3578347193-3.53708888880 .3855044049$

H $10.2277799651-3.66857129261 .0407060484$

C $8.7473250458-2.2185094440 .3601464931$

C $7.6044544074-1.9556721605-0.432266646$

C $7.0379119176-0.6763367029-0.4198976496$

$\begin{array}{llll}\text { C } 7.5813655441 & 0.3333660773 & 0.3643773022\end{array}$

$\begin{array}{llll}\text { C } 8.715469211 & 0.0768245999 & 1.1518288294\end{array}$

C $9.2814754843-1.1841768122 \quad 1.1427196651$

N $7.3099656758-6.7468107047-0.3581888956$

N $8.8883961436-4.5099425546-0.3099296745$

O $5.1627035162-5.6483698555-1.3710698023$

H $6.1236105602-5.8323519744-1.2131910378$

O $7.039974237-2.8932260249-1.1970999768$

H $7.5564037118-3.7294350027-1.0658621222$

O $12.8333125445-7.3928955227-0.2948383626$

O $11.3418903758-9.5008005186-0.314879674$

C $10.5693985201-10.6848901692-0.3567123921$ 
H $9.9204934138-10.77130318880 .5229055632$

H $9.9573062542-10.7323166533-1.2649783149$

H $11.2818662157-11.5088937795-0.3599677302$

C $13.6931519273-6.2701117045-0.309951491$

H $13.5415780782-5.6611369232-1.2088774602$

H $13.5513144342-5.64476348850 .5795083858$

H $14.7072733987-6.6677813555-0.3117929457$

H $10.1568607384-1.3900526561 \quad 1.7531684575$

H $9.1359300607 \quad 0.8683877322 \quad 1.7621960193$

H $4.7902406886-8.8862202197 \quad 1.8003719083$

H $2.3186764551 \quad-8.7059405114 \quad 1.7699429962$

H $6.1600869087-0.492070586-1.0298413366$

H 2.6031650107 -5.6362478182 -1.2296497091

C $0.8143513639-7.0327085903 \quad 0.2555560878$

C $0.040414801-7.9436341976-0.4826872369$

C $0.195092294-6.0047352050 .9868196744$

C $0.641524724-8.9938940862-1.2510360543$

C $0.9549687868 \quad-5.0656048332 \quad 1.7586016129$

C $-0.1185957919-9.8655927555-1.9709583317$

H $1.7222300623-9.082255544-1.2550247399$

C $0.3432767012-4.0774623423 \quad 2.4692795319$

H $2.0355976206-5.15239607841 .7667682795$

H $\quad 0.3563301715-10.6523241107$-2.5481877061

H $0.9373685682 \quad-3.3749016415 \quad 3.0446829407$

C $6.95027908831 .6862143992 \quad 0.3732589342$

C $7.4918921483 \quad 2.7169541208$-0.4130629933

C $5.8137170748 \quad 1.9209011908 \quad 1.1659109328$

C $6.88009178114 .0155461509-0.4082606785$

C $8.64176289892 .507675493-1.2429385408$

C $5.2011660892 \quad 3.2192417612 \quad 1.1693054313$

C $5.2439251393 \quad 0.8956062168 \quad 1.9899845972$

C $5.7420233047 \quad 4.2491937972 \quad 0.3813101752$

C $7.44970506795 .042172712-1.2304847258$

C $9.1530618468 \quad 3.5130643002 \quad-2.007045404$

H $9.1010754441 \quad 1.5255598269-1.2572482226$

C $4.04714280283 .4278804432 \quad 1.9936651664$

H $5.7048022064-0.08571200961 .9927854593$

C $4.1440005913 \quad 1.1365095829 \quad 2.7567347111$

C $8.54764607614 .8015210861-2.0002414537$

H $6.98580540926 .0223068142-1.2338795136$

H $10.0230886614 \quad 3.3331955355-2.6302526307$

C $3.5352897086 \quad 2.4232265984 \quad 2.758136208$

H $3.5811857096 \quad 4.4068246493 \quad 1.9985488233$

H 3.72720214820 .34565875693 .3719449088

H $8.96248435525 .591739418-2.6176054144$

H $2.6594813391 \quad 2.6014005542 \quad 3.3736431183$

C $5.1004442099 \quad 5.5972824928 \quad 0.3815609171$

C $4.00442110315 .8400576672 \quad-0.4367247258$

C $5.5958764041 \quad 6.6152049742 \quad 1.2123273661$

C $3.37817806547 .0913014829-0.440171347$

H $3.6105376225 .0610504618-1.0805417578$

C $4.9826724932 \quad 7.8539682582 \quad 1.2129533998$

H $6.4522103164 \quad 6.4203976916 \quad 1.8484101315$
C $3.8723533488 \quad 8.11911310090 .3978737855$

$\begin{array}{lllll}\text { O } & 2.3250346547 & 7.2728350095 & -1.2409223328\end{array}$

H $5.35859819428 .6449942663 \quad 1.856628306$

C $3.2405951372 \quad 9.42728585 \quad 0.4370080894$

H $2.00226265118 .1988908533-1.0962701215$

H $3.6722087633 \quad 10.166565223 \quad 1.1229262862$

N $2.2108966936 \quad 9.7006645707 \quad-0.2806668678$

C $1.640438551610 .9843964202-0.2585339598$

C $2.42638058412 .1471000738-0.2403949841$

H $3.504336175212 .0446769767-0.2689221526$

C $1.8438608478 \quad 13.4047677762-0.231323104$

O $2.523463508914 .5745217543-0.235027812$

C $3.9363854784 \quad 14.5139696841 \quad-0.2529636591$

H $4.3266522017 \quad 13.999627438 \quad 0.6332764561$

H $4.3046915598 \quad 14.0116267505-1.1551339684$

H $4.2818089219 \quad 15.547059799-0.2502205249$

C $-3.4975538679-6.6748164773 \quad 0.2386568428$

C $-4.1132881852-5.7427182597-0.587268155$

C $-5.5054004124-5.6012392014-0.5923821987$

C $-6.2917410529-6.4226825921 \quad 0.250143127$

C $-5.6501823597 \quad-7.3603613986 \quad 1.0726227336$

C -4.2744440608 $-7.4930073164 \quad 1.0748382694$

C $-7.7392489132-6.2971813065 \quad 0.2861369544$

H $-8.2787237515-6.96225072690 .9719262492$

C $-9.761778818-5.3554139105-0.4152805393$

C $-10.569835854-6.5029200886-0.4063118408$

H -10.0905349179 -7.4737039092 -0.4406869804

C $-11.9524945888-6.4043131521-0.3994909458$

C $-12.5584097827-5.1252934254-0.4048322552$

C -11.7595928515 $-3.9927033645-0.4164276022$

H $-12.2091997206-3.0081374676-0.458091435$

C $-10.3597223724-4.0932833005-0.4198656995$

C -9.8165298428 -1.92239940990 .261338549$

H $-10.6849203104-1.90683459530 .9315388358$

C $-8.9914227459 \quad-0.72648666090 .2260563094$

C -7.8359312307 $-0.6570159698-0.5882071753$

C $-7.05519288520 .5042599773 \quad-0.5775733053$

C -7.4009224103 $1.5842493391 \quad 0.2247779164$

C -8.5493188484 $1.5214603177 \quad 1.0303130231$

C $-9.3251526686 \quad 0.3776078731 \quad 1.0242077496$

N -8.3590035513 $-5.4332751175-0.4347270137$

N $-9.5303891502-2.9594847327-0.4405987118$

O $-6.0484367674-4.6865182604-1.3996463323$

H -7.0288160719 -4.7117855304 -1.2543102095

O $-7.4575074593-1.6699769143-1.3716991483$

H -8.1054960255 -2.4072280924 -1.2320664118

O $-13.9111311667-5.1203324641-0.4210261333$

O $-12.8057919069-7.4540269709-0.4111785581$

C $-12.2492191026-8.7540673918-0.4336107096$

H $-11.6465894898-8.9166877875-1.3348647812$

H -11.6325286613 -8.94123233750 .4534983444$

H -13.0933304991 -9.4425888494 -0.4363922189

C $-14.5634901893-3.8659359851-0.4551844093$

Page: S86 
H -14.3206100228 -3.26391271880 .4284917685$ H -14.3034709147 $-3.3033380997-1.3594969905$ H -10.2118056856 0.32066101851 .6501160978 H $-8.814903423 \quad 2.3677647921 \quad 1.6541101163$ H -6.2566343061 $-7.9877520004 \quad 1.7204856803$ H $-3.7890017128-8.2194743604 \quad 1.7170981355$ H $-6.16870039420 .5389259903-1.2016603434$ H -3.524450896 $-5.1025705281-1.2353526576$ C - $2.0097441053-6.79759355510 .2426092936$ C $-1.3901265176-7.8243377736-0.4895156102$ C $-1.2356832912-5.8857540187 \quad 0.9806290497$ C $-2.1492952653-8.7604573271-1.2654295954$ C $-1.8360669488-4.8340270021 \quad 1.747824078$ C $-1.5371701754-9.7467923962-1.978468449$ H -3.2295405981 -8.6678374384 -1.2805096411 C $-1.0752177103 \quad-3.9600276507 \quad 2.4640102668$ H -2.9161972919 -4.74128707891 .7484635233$ H -2.1302289193 -10.4438682098 -2.5616198414 H $-1.5498712819-3.16913444493 .035694204$ C $-6.541535465 \quad 2.8049772835 \quad 0.2399871869$

C $-6.8669218436 \quad 3.9025200608$-0.5738949371 C $-5.4103067743 \quad 2.8490299682 \quad 1.0723092901$ C $-6.0393745078 \quad 5.0752636028-0.5548473611$ C $-8.0077265043 \quad 3.8857270268-1.4415393426$ C $-4.5825395393 \quad 4.0217064511 \quad 1.0911479042$ C $-5.0557300841 \quad 1.7492298745 \quad 1.9204705729$ C -4.9085449927 5.11965382390 .2773705603 C $-6.3926964876 \quad 6.1741494002-1.4045350878$ C -8.3088949141 $4.9541797665-2.2313484517$ H $-8.63132913172 .9988484829-1.4634680163$ C -3.4399403925 $4.0371115717 \quad 1.9566402625$ H -5.67855931280 .86181178551 .9088963759$ C $-3.9590238726 \quad 1.8051664099 \quad 2.7265719112$ C -7.4880616272 $6.1173141522-2.2125317099$ H $-5.76562058827 .0587919553-1.3975597313$ H $-9.1757753184 .9208387684-2.8833256131$ C $-3.1378479808 \quad 2.96783711892 .7448630959$ H -2.8114709433 $4.9204681264 \quad 1.9733718473$ H $-3.70655601170 .9606789317 \quad 3.3596190882$ H -7.7372397992 6.9591520707 -2.8504070246 H $-2.2668884521 \quad 2.9986850514 \quad 3.3914780211$ $\begin{array}{llll}\text { C } & -4.0492275782 & 6.3403835075 & 0.2978484085\end{array}$ C -2.9076959159 $6.3964355995-0.4917482676$ C $-4.3907545741 \quad 7.4285261371 \quad 1.1169819001$ C - $2.0852338567 \quad 7.5285080421-0.479753061$ H -2.6315902853 $5.5614305938-1.1265627289$ C -3.5832619101 $8.5501194574 \quad 1.1328080876$ H $-5.2830925399 \quad 7.3794327245 \quad 1.7311556682$ C - $-2.4257257083 \quad 8.6273694841 \quad 0.344506707$ O $-0.9970466121 \quad 7.5320614321-1.2538297836$ H -3.8404116689 $9.3945120976 \quad 1.766872136$ C $-1.5934234874 \quad 9.817641387 \quad 0.3948435807$ H $-0.53245838828 .3947832612-1.1035850811$
H -1.916396126 $10.6206106722 \quad 1.0689668996$ N $-0.518454781 \quad 9.9190877195 \quad-0.3010425927$ C $0.248333738311 .0959479865 \quad-0.2699740976$ C $-0.3422611045 \quad 12.3692121457-0.2641433037$ H $-1.422088825 \quad 12.4401598947-0.3117844663$ C $0.4330948492 \quad 13.5179008917-0.243388835$ O $-0.051379678 \quad 14.7809324936-0.2566861641$ C $-1.4553631573 \quad 14.9461347285 \quad-0.3000963541$ H $-1.882549214 .5079342391-1.2097135182$ H - $-1.938650582 \quad 14.50114665010 .577817497$ H -1.6319443944 $16.02102111-0.3014855974$ H -15.6311115532 -4.0820769013 -0.4605885456

\section{Macrocycle 1 - Conformer I-(HB)} $6-31 \mathrm{~g}(\mathrm{~d}, \mathrm{p}) / \omega \mathrm{B} 97 \mathrm{XD} / \mathrm{CHCl} 3$

C $-5.9586933904 \quad 0.463227755 \quad 4.3948932692$

C $-6.1188745656-0.2087466106 \quad 3.1889005921$

C -7.3549096867 $-0.2165485135 \quad 2.5316924357$

C $-8.4522775195 \quad 0.4679297725 \quad 3.1096488011$

C $-8.2656228728 \quad 1.1491215942 \quad 4.3205089069$

C -7.0420660368 $1.1520600137 \quad 4.9629793134$

C $-9.7542443563 \quad 0.48049193312 .462229658$

H -10.5412082053 1.08458917112 .9305649019

C $-11.1934102113-0.2186014666 \quad 0.7324663801$

C -12.4158845584 $-0.1901167078 \quad 1.4219694081$

H -12.4049669471 -0.15241142 .5043650829$

C $-13.6198865747-0.2554589255 \quad 0.7398202078$

C $-13.6152632673-0.3584449345-0.6727919685$

C $-12.4072817346-0.3879992835-1.3517501892$

H $-12.3898024329-0.5064020949-2.4281952813$

C $-11.1858885642-0.3166531179-0.6619498596$

C $-9.7706879954 \quad 0.2557224756-2.408257117$

H $-10.57807658120 .8726988657-2.8300518779$

C $-8.4892125986 \quad 0.2367723374-3.1221712629$

C $-8.389523613 \quad 0.6604212218-4.4590222461$

C $-7.1481050854 \quad 0.690161276-5.0949452659$

C $-5.9971893794 \quad 0.2906811932-4.4252783626$

C $-6.0898036155-0.1460665137-3.0962008025$

C -7.3187191741 $-0.1685693476-2.4621698737$

N $-9.9516320411-0.1760133398 \quad 1.3782380123$

N $-9.9422338986-0.3689533678-1.3094449876$

O $-7.4569006017-0.8776393128 \quad 1.3739760201$

H -8.3993409304 $-0.7888181521 \quad 1.0632192801$

O $-9.4493534679 \quad 1.0592937836-5.2086825276$

H -10.2803947939 $0.8404849956-4.7785415343$

O $-14.8339918138-0.4441317507-1.2539162938$

$\begin{array}{llll}\text { O } & -14.8426805212 & -0.2548538421 & 1.3200979968\end{array}$

C $-14.9000157953-0.18562822332 .7312907284$

H -14.4413119885 $0.7370259742 \quad 3.1065829283$

H -14.4086865921 -1.0489412254 3.1953510196

H $-15.9580823784-0.19207205282 .9903263971$ 
C $-14.8852234382-0.574466685-2.6609651119$

H -14.3878683746 $-1.4917791871-2.9972787071$

H $-14.42985073220 .2891984943-3.1601088624$

H - $15.9420639703-0.6229000363-2.9204354186$

H -7.398683429 $-0.4796735267-1.4255933009$

H $-5.1937499019-0.4534684572-2.5679860296$

H $-9.10832262 \quad 1.6794408621 \quad 4.756312695$

H $-6.9110373242 \quad 1.6767252476 \quad 5.902939736$

H -7.101048429 $1.0197320967-6.1273051807$

H $-5.2884193298-0.74171910772 .7381660152$

C $-4.64279652990 .4497124554 \quad 5.0998966322$

C $-4.4438511004-0.4277647085 \quad 6.1797617346$

C $-3.6194937817 \quad 1.3261734102 \quad 4.7010711971$

C $-5.4566603935-1.3527988151 \quad 6.5965361637$

C $-3.7899994876 \quad 2.2360162563 \quad 3.6065570089$

C -5.2510691964 -2.2010278472 7.6426706607

H $-6.39713865-1.3723147886 \quad 6.0574272325$

C - $-2.7932704005 \quad 3.086844413 \quad 3.2344619582$

H $-4.7331092707 \quad 2.2347418183 \quad 3.0716462539$

H -6.0297720291 -2.89616200067 .9394833472$

H -2.9414091308 3.76535765862 .400605862

C $-4.6823336803 \quad 0.3295972213-5.1303710028$

C $-4.346244286-0.6873238854-6.0406164167$

C $-3.79321480851 .392233004-4.8944970921$

C $-3.0982398999-0.6289083612-6.7475506357$

C $-5.2166045111-1.7998575946-6.2855015407$

C $-2.54061079781 .4442894584-5.5937956121$

C $-4.1053089817 \quad 2.4479827424-3.9765069921$

C $-2.21416824060 .4386020361-6.5184686546$

C - $-2.7932953907-1.6713169297-7.6830679526$

C $-4.8834809133-2.7742060305-7.1775467503$

H -6.1530463577 $-1.8574320736-5.7421761761$

C $-1.6520478902 \quad 2.5364640171-5.3254963385$

H $-5.05511420372 .4197663078-3.4542895729$

C $-3.2330402086 \quad 3.4705982982-3.7540824735$

C $-3.6540038456-2.706367707-7.8917580736$

H - $1.8548389111-1.6255163046-8.2242311285$

H $-5.5555898449-3.6094781563-7.3456441173$

C - $-1.9841400793 \quad 3.5133538671-4.4359385788$

H - $0.69978662752 .5714446939-5.8430968012$

H -3.4878452759 $4.2586569362-3.0528753084$

H -3.4030064918 $-3.4871563803-8.6024149592$

H - $-1.29605932314 .3301537039-4.2437328043$

C $-0.93188932490 .5146327695-7.2795782212$

C $0.1895289599-0.1725222256-6.8330498019$

C $-0.8657658473 \quad 1.2787798385-8.4561042565$

C $1.3921682855-0.119538538-7.5477670684$

H $0.1517856685-0.7635435349-5.9242795249$

C $0.3179713615 \quad 1.3369730022-9.1661639735$

H - $1.7440275894 \quad 1.8152262328-8.7977093329$

C $1.4603296855 \quad 0.6443985123-8.7382281819$

$\begin{array}{lllll}\text { O } & 2.4414391954 & -0.7981811186 & -7.0775654725\end{array}$

H $0.3750757743 \quad 1.9254888039-10.0780881417$ $\begin{array}{llll}\text { C } & 2.686942834 & 0.7219713547 & -9.5122034452\end{array}$

H $3.1980268914-0.6401665435-7.7012765561$

H $2.6706767947 \quad 1.3536738596-10.4089838771$

N $3.74405510980 .0879189014-9.1500707359$

C $4.9212638960 .129435867-9.916032656$

C $4.90558989110 .1455891116-11.3192193758$

H $3.95122980130 .1159402251-11.8305348835$

C $6.08477188710 .1537501669-12.0478036669$

$\begin{array}{lllll}\text { O } & 6.1620848682 & 0.1676198107 & -13.3982964217\end{array}$

C $4.94999842780 .198565452-14.1264088857$

H $4.360728521 \quad 1.0911773612-13.885277607$

H $4.3457309347-0.6966186579-13.9378393259$

H $5.23158189930 .2263557395-15.178307249$

C $-0.89726732760 .5035238606 \quad 7.265488235$

C $0.2114058364 \quad-0.1979747445 \quad 6.8092052404$

C $1.412066954-0.18517436817 .5291018288$

C $1.49055401130 .5504466309 \quad 8.7365803904$

C $0.3612341747 \quad 1.2577485348 \quad 9.1747261566$

C $-0.8198799315 \quad 1.24095198328 .4583836882$

C 2.71349336750 .58487002399 .5193040392

H 2.70477015341 .198877765210 .4284416355

C $4.9308567622-0.0613854415 \quad 9.9278322526$

C $4.9046737264-0.075163373511 .3307054372$

H $3.9461813157-0.100195298911 .8342187826$

C $6.0781655811-0.102079243912 .0679358425$

C $7.323025279-0.1203506518 \quad 11.3946322321$

C $7.3478802899-0.1279100522 \quad 10.0085899063$

H $8.293756983-0.10551016439 .4812184757$

C $6.1588305753 \quad-0.1192687963 \quad 9.2636486631$

C $7.0126018365-0.7494314479 \quad 7.1694969479$

H $7.7730787753-1.38126306127 .6447270034$

C $7.005279913-0.70050318065 .7180258917$

C 6.03458459790 .0565806595 .0175474324

C $6.0524378595 \quad 0.0685694523 .6182071323$

C $7.0063527337-0.65466962492 .9136157132$

C $7.969650808-1.40728156513 .6050634592$

C $7.9591397028-1.4238048823 \quad 4.9867315154$

N $3.7591774901-0.06476671869 .1519376842$

N $6.1488482869-0.094956128 \quad 7.8593702216$

$\begin{array}{lllll}\text { O } & 2.4487809325 & -0.8760020638 & 7.0482652033\end{array}$

H $3.204921919-0.7504034883 \quad 7.6790379174$

$\begin{array}{lllll}\text { O } & 5.0939351264 & 0.764171417 & 5.6475320207\end{array}$

H $5.22485402420 .6235962381 \quad 6.62263528$

$\begin{array}{lllll}\text { O } & 8.4170742934 & -0.1248585544 & 12.1902654236\end{array}$

$\begin{array}{lllll}\text { O } & 6.1444998572 & -0.1175903703 & 13.4189748799\end{array}$

$\begin{array}{llll}\text { C } 4.9273981412 & -0.0740698632 & 14.138147017\end{array}$

H $4.3058234425-0.952660223513 .9288880428$

H $4.3589559741 \quad 0.8349983374 \quad 13.9084867313$

H $5.200994896-0.0710636534 \quad 15.1925256879$

C $9.6852111114-0.162293057611 .5651199039$

H $9.85259527280 .7255216877 \quad 10.9439373919$

H $9.8020451111-1.062372431 \quad 10.9499788812$

H $8.6989172015-2.00792917015 .5278019478$

Page: S88 
H $8.7111986835-1.97066535953 .0495724308$

H $0.4272156373 \quad 1.8254050498 \quad 10.0991694738$

H -1.6884105251 .78759106118 .8086012727$

H $5.30031724590 .6492734992 \quad 3.0951044072$

H $0.1654221911-0.76807248065 .8875328755$

$\begin{array}{llll}\text { C }-2.1782477446 & 0.4704958127 & 6.4992756852\end{array}$

C $-3.1961354213-0.4164095246 \quad 6.8888838805$

C $-2.3703183138 \quad 1.335933486 \quad 5.4094661207$

C -3.0233085024 $-1.3275354726 \quad 7.981984863$

C $-1.3521369119 \quad 2.2519581808 \quad 4.9863754$

C $-4.0144688708-2.1877499593 \quad 8.3474755262$

H - $2.0793336598-1.32608097418 .5154815757$

C - $-1.55404390423 .0944180706 \quad 3.9350630062$

H $-0.40755276772 .2621872468 \quad 5.5186454305$

H -3.8621178925 -2.87217117119 .1757817719$

H $-0.7688823796 \quad 3.77767668613 .6281587821$

C $7.0018396599-0.63575773761 .4209968824$

C $6.1228355661-1.4736640797 \quad 0.7139628453$

$\begin{array}{llll}\text { C } 7.8779930849 & 0.2182240549 & 0.7303921278\end{array}$

C $6.1210845149-1.4577595468-0.7216314384$

C $5.2242188205-2.36413358891 .38812363$

$\begin{array}{llll}\text { C } 7.8759188593 & 0.2346188388 & -0.7048875944\end{array}$

C $8.7764986191 \quad 1.0953729661 \quad 1.4218425976$

C $6.9980364892-0.6039627315-1.4121899274$

C $5.2213150207-2.3339260685-1.4128391133$

$\begin{array}{llll}\text { C } 4.3818118719 & -3.1769493638 & 0.6913770348\end{array}$

H $5.2228440895 \quad-2.38033400192 .4721700452$

C $8.7716669604 \quad 1.1283723385-1.3784433498$

H $8.7753917462 \quad 1.0911963382 .5061667848$

C $9.61528704181 .9259572755 \quad 0.7417102567$

C $4.3805397974-3.1617525005-0.7319840395$

H $5.217899421-2.3270762837-2.4969543426$

H $3.7075065491-3.8420626425 \quad 1.2209856841$

C $9.61267096871 .9428727562-0.6817454102$

H $8.76685774931 .1500740576-2.4625415839$

H $10.2864078152 .5839600549 \quad 1.2842673539$

H $3.7055008316-3.815674012-1.2744323327$

H $10.28161592212 .6138257061-1.2109603527$

C $6.9987806485-0.5898645254-2.9048228462$

C $6.0335454590 .1358654751-3.5912652273$

C $7.9701669303-1.3140385103-3.6150910028$

C $6.01249341690 .1545892523-4.9904474704$

H $5.27517288320 .6949990746-3.0538191216$

C $7.9565561674-1.2997979818-4.9967387609$

H $8.7206833024-1.87956961-3.0739992539$

C $6.9913067523-0.5733487461-5.709820458$

$\begin{array}{lllll}\text { O } & 5.0608439368 & 0.8637145786 & -5.6020446239\end{array}$

H $8.7031297603-1.8611975903-5.5523123237$

C $6.99841183-0.5885628496-7.1620797177$

H $5.19096235480 .7487812497-6.5799885788$

H $7.7681000254-1.1989267243-7.650500447$

N $6.12686127740 .0697971891-7.8385675556$

C $6.14504446290 .0778563979-9.243403862$
C $7.33929353230 .1059708479-9.9795507642$

H $8.28082594340 .1336932838-9.4448336012$

C $7.3245391308 \quad 0.1419577535-11.3652032848$

$\begin{array}{lllll}\text { O } & 8.4245073883 & 0.1715160176 & -12.1519580455\end{array}$

C $9.68812774260 .1375650191-11.5176038671$

H $9.8121046642-0.7738225456-10.9207677088$

H $9.8388577811 \quad 1.0141172198-10.8765489298$

H $10.42696729030 .1470998875-12.3179596851$

H $10.4175415227-0.1795706003 \quad 12.3713146081$

Macrocycle $\mathbf{1}$ - Conformer $\mathbf{J}$

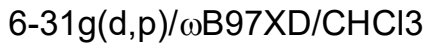

$\begin{array}{llll}\text { C }-2.7327424326 & 7.0904285232 & 0.0212551287\end{array}$

C $-3.4874517447 \quad 6.0096485245-0.4200914788$

C $-4.8862215254 \quad 6.0538991102-0.3971287254$

C $-5.537186804 \quad 7.20503882730 .1061827286$

C $-4.7583253565 \quad 8.2859691656 \quad 0.5456071901$

$\begin{array}{llll}\text { C }-3.3788445992 & 8.2439431582 & 0.4984829125\end{array}$

$\begin{array}{llll}\text { C } & -6.9840568519 & 7.2706384926 & 0.2045717784\end{array}$

H -7.4040166952 8.16904650380 .6731989691

C $-9.13248296966 .3969431835-0.1047700816$

C $-9.82053388617 .6122944893-0.254724708$

H $-9.25580806868 .5054578762-0.4915605018$

C $-11.19991327437 .6754816034-0.1468092321$

C $-11.9300169205 \quad 6.4926542681 \quad 0.1209648102$

$\begin{array}{llll}\text { C }-11.2547609998 & 5.2891117663 & 0.2391702869\end{array}$

H $-11.8019111187 \quad 4.38457833740 .4746310926$

$\begin{array}{llll}\text { C }-9.8584760125 & 5.2199786089 & 0.1006453018\end{array}$

C $-9.66546235472 .9053700987-0.1943468189$

H $-10.65679310642 .8680157562-0.6621040354$

C $-8.94716388991 .647785425-0.0930497137$

C $-7.6236935319 \quad 1.59543290690 .4050427689$

$\begin{array}{lllll}\text { C } & -6.9446929999 & 0.3717610856 & 0.4262934028\end{array}$

C $-7.5624837086-0.7940199623-0.0113653019$

C $-8.8857296923-0.7472413486-0.483126836$

C $-9.55409344050 .4604036192-0.5289162119$

N -7.7327107712 $6.3108239715-0.2084226793$

$\begin{array}{llll}\text { N }-9.1505713236 & 4.0103159037 & 0.2133231898\end{array}$

$\begin{array}{lllll}\text { O } & -5.5634454997 & 4.9943975686 & -0.8463400877\end{array}$

H $-6.52915313475 .189694941-0.7352547672$

$\begin{array}{lllll}\text { O } & -6.9889936591 & 2.6824214071 & 0.8506498452\end{array}$

H -7.6038197289 $3.4525013972 \quad 0.7383317029$

$\begin{array}{lllll}0 & -13.268015083 & 6.6479848327 & 0.2427153154\end{array}$

O $-11.9384055554 \quad 8.8007069961-0.279452447$

C $-11.2522031204 \quad 10.0134738974-0.5227520663$

H -10.7054718313 $9.9815917852-1.4724071215$

H -10.5544453789 10.2481656420 .289823256

H -12.0174315701 $10.7869254534-0.5752379501$

C - $14.0460202853 \quad 5.492233414 \quad 0.4862191171$

H -13.7783146907 5.02156581161 .4394466812

H $-13.93886405634 .7599583918-0.3228120903$ 
H -15.080534065 $5.8301977925 \quad 0.5313110641$ H -10.5717935543 $0.5027875722 \quad-0.907794208$ H -9.3671331155 $-1.6583016747-0.8210051654$ H $-5.2607671201 \quad 9.17056835090 .9279536281$ H -2.7882361204 9.08718638270 .8391824129 H $-5.92367832590 .3536927977 \quad 0.7922160872$ H $-3.0046626303 \quad 5.1116916068$-0.7905168138 C $-1.2421868621 \quad 7.0285128382-0.0002642418$ C $-0.5295479172 \quad 6.9903260242 \quad 1.2128058126$ C $-0.5513494468 \quad 7.0192513855-1.2260230414$ C - $1.1991787243 \quad 6.9482111312 \quad 2.4804988604$ C $-1.2387913177 \quad 7.0850969131 \quad-2.4829530278$ C $-0.5025119335 \quad 6.9481683996 \quad 3.6509054093$ H $-2.2820409993 \quad 6.9107063032 \quad 2.4966793644$ C $-0.56244288357 .0397681743-3.6643713522$ H $-2.31907939247 .1687123073-2.4823887442$ H $-1.0315334465 \quad 6.9115787664 \quad 4.5976870063$ H -1.1052844803 $7.0884679401-4.6027557519$ C $-6.8256531351-2.09126539290 .0085582573$ C $-6.4955707909-2.6985374923 \quad 1.2341009829$ C $-6.4711219685-2.710161255-1.2048162329$ C $-5.7830216257-3.9454610461 \quad 1.2453388533$ C $-6.8637548395-2.1148697197 \quad 2.4911719273$ C $-5.804407127-3.982407174-1.1932529457$ C $-6.7466235484-2.098871156-2.4726774915$ C $-5.4618026496-4.5826467476 \quad 0.0323472994$ C $-5.4068054857-4.50201191912 .5125574097$ C -6.508413493 $-2.6925707037 \quad 3.6723998366$ H $-7.4339106524 \quad-1.193343506 \quad 2.4899497575$ C $-5.5199277734-4.6119961314-2.4500537917$ H -7.2099339238 $-1.1194671651-2.4893963593$ C $-6.4328619566-2.7209630893-3.6430969005$ C $-5.7526998299 \quad-3.8977079598 \quad 3.6831989815$ H -4.8309741491 -5.41997178832 .5274667537$ H $-6.7965715936-2.23046333424 .6110493867$ C $-5.8241873413-4.0065265218-3.6315713007$ H $-5.0502131462-5.5884469807-2.4492967885$ H $-6.647832465-2.2365469444-4.5900190069$ H -5.4527725675 -4.3355846293 4.629745542 H $-5.5969045636-4.5021713255-4.5698599736$ C $-4.7696175653-5.9043476656 \quad 0.0533435893$ C $-3.4572560513-6.0185699123-0.3906279641$ C $-5.4461062236-7.0404511433 \quad 0.5298325852$ C $-2.79806453-7.2531218465-0.372446765$ H $-2.9203838018-5.1516617245-0.7606482123$ C $-4.794637756-8.2573553684 \quad 0.5726176316$ H $-6.470841416-6.94983732160 .8728848056$ C -3.4706020225 -8.39287256290 .1291249024$ O $-1.5427133166-7.310563988-0.8242900048$ H $-5.3102785755-9.13487781640 .9536763023$ C -2.806902249 $-9.6807204155 \quad 0.2214186271$ H -1.2323027743 -8.2465988775 -0.7212407361 H $-3.3741775945-10.49210647120 .6934852937$
N -1.6047897046 $-9.8513862709-0.2002618841$ C $-0.978228101-11.1062381112-0.1021968256$ C $-1.686217552-12.3116251915-0.2405048525$ H - 2.7455032055 -12.2722573381 -0.4619858063 C $-1.0470473726-13.5362924893-0.1395699763$ O $-1.6518809749-14.7399226395-0.2608989252$ C -3.0481626751 -14.7557331295 -0.4858004323 H $-3.3078404309-14.267300076-1.4324276809$ H $-3.5909223302-14.27002166240 .3337141941$ H -3.3332367712 -15.8059504715 -0.5339269396 C $3.0887275631 \quad 6.9403418554 \quad-0.044656924$ C $3.7851941665 \quad 5.8214667236 \quad 0.3972417499$ C $5.1843136576 \quad 5.7938132834 \quad 0.3796077648$ C $5.8958992597 \quad 6.9103959172 \quad-0.1194639212$ C $5.17512578598 .0301688334-0.5609934462$ C $3.79510518148 .0593068242-0.5186606832$ C $7.34470336096 .902410846-0.2117487275$

H $7.8110898417 \quad 7.7789192708$-0.6777788984

C $9.4448975568 \quad 5.9191828115 \quad 0.1058477597$

C $10.19570883 \quad 7.0978608648 \quad 0.2498658247$

H $9.6784228467 \quad 8.02197872590 .4766143585$

C $11.5770258573 \quad 7.08734761880 .1478633802$

C $12.2453039725 \quad 5.8658546971 \quad-0.1077341874$

C $11.50791477314 .6990079179-0.2213095555$

H $12.006757987 \quad 3.7650401944-0.4486782771$

C $10.10951117454 .7045743419-0.0884752994$

C $9.797299978 \quad 2.4051789590 .220499326$

H $\quad 10.7817155281 \quad 2.3221480348 \quad 0.6969151728$

C $9.0184101703 \quad 1.18427561590 .1187961068$

C $7.69890359331 .1959511117-0.3923195686$

C $6.95894979750 .0080258374-0.4147026765$

C $7.5132855974-1.1855123915 \quad 0.0331428632$

C $8.8330135277-1.20307277890 .5169133889$

C $9.5608004174-0.03040745130 .5647911093$

N $8.0420802981 \quad 5.9058422412 \quad 0.2039299223$

N $9.3413835703 \quad 3.5319652062-0.1976588725$

$\begin{array}{lllll}\text { O } & 5.8035914945 & 4.7000186526 & 0.8303427214\end{array}$

H $\quad 6.7786083627 \quad 4.8450497236 \quad 0.7239593108$

$\begin{array}{lllll}\text { O } & 7.1246854378 & 2.3112566243 & -0.849309079\end{array}$

H $7.77678001693 .0497227741-0.7348682449$

O $13.5901932063 \quad 5.9489457796-0.2239476025$

$\begin{array}{lllll}\text { O } & 12.3734525783 & 8.1730798666 & 0.275033473\end{array}$

C $11.751810293 \quad 9.4221786873 \quad 0.5068763693$

H $11.200894436 \quad 9.426283045 \quad 1.4547230393$

H $11.0703571555 \quad 9.6877349913 \quad-0.3099606442$

H $12.5568862295 \quad 10.1541697578 \quad 0.5565845992$

C $14.30628608354 .7515905138-0.4569695177$

H $14.0188299951 \quad 4.2911247167-1.4094798726$

H $14.1550521179 \quad 4.0302771290 .3547964775$

H $10.5759701719-0.03820342850 .9528501242$

H $9.2649535483 \quad-2.1358548033 \quad 0.8624275077$

H $5.7240681175 \quad 8.8877633537 \quad-0.9408071946$

H $3.2500856353 \quad 8.9324846917-0.8599121341$ 
$\begin{array}{llll}\text { H } & 5.9417419217 & 0.0398711946 & -0.7902466341 \\ \text { H } & 3.2559609208 & 4.9488975224 & 0.764917032 \\ \text { C } & 1.5970807965 & 6.9558558694 & -0.0245165976 \\ \text { C } & 0.9066331795 & 6.9802860724 & 1.2012288421 \\ \text { C } & 0.883569688 & 6.9562303705 & -1.2376322523 \\ \text { C } & 1.5966220049 & 7.0104214663 & 2.4580694812 \\ \text { C } & 1.5505216855 & 6.8833078669 & -2.505228365 \\ \text { C } & 0.9189979189 & 6.9973149277 & 3.6395419359 \\ \text { H } & 2.6797457193 & 7.0408846325 & 2.4572002734 \\ \text { C } & 0.8549451614 & 6.920906276 & -3.6756918821 \\ \text { H } & 2.6301966617 & 6.7925217656 & -2.5213968819 \\ \text { H } & 1.4636575025 & 7.0181909311 & 4.5778952486 \\ \text { H } & 1.3816916608 & 6.8608155459 & -4.6224874646 \\ \text { C } & 6.7122393432 & -2.444024622 & 0.0102886264 \\ \text { C } & 6.320119518 & -3.0428677099 & 1.2221511843 \\ \text { C } & 6.3595618212 & -3.0358009183 & -1.2166678916 \\ \text { C } & 5.5910481689 & -4.2803813057 & 1.2079306806 \\ \text { C } & 6.6174345036 & -2.4442492897 & 2.4912748819 \\ \text { C } & 5.5859972627 & -4.2458116808 & -1.2308390184 \\ \text { C } & 6.7627979916 & -2.4726430069 & -2.4724692905 \\ \text { C } & 5.2258900314 & -4.8643551588 & -0.0190388216 \\ \text { C } & 5.2688768869 & -4.8940108759 & 2.4634689301 \\ \text { C } & 6.2664042784 & -3.0486590907 & 3.6603646644 \\ \text { H } & 7.1279274902 & -1.488632653 & 2.5100627954 \\ \text { C } & 5.1904885166 & -4.7852484836 & -2.4994983785 \\ \text { H } & 7.3771399413 & -1.5800124064 & -2.4694128997 \\ \text { C } & 6.3859819792 & -3.0336972596 & -3.6550652503 \\ \text { C } & 5.5956760507 & -4.3029633333 & 3.6462976342 \\ \text { H } & 4.7520073658 & -5.8464046169 & 2.4606467504 \\ \text { H } & 6.4987797841 & -2.5739827765 & 4.6081686299 \\ \text { C } & 5.5725925292 & -4.2006212503 & -3.6688571018 \\ \text { H } & 4.5708400424 & -5.6740798283 & -2.5165431133\end{array}$
H $6.7014923893 \quad-2.5872815718$-4.5925400243

H $5.3391438827-4.7860016608 \quad 4.5835893928$

H $5.2575209791-4.6250242954-4.616572126$

C $4.4670732076-6.1487350201-0.0426278949$

C $3.1487179159-6.19463837240 .3964960561$

C $5.0855326215-7.3184385503-0.5171458947$

C $2.4266409335-7.3934425584 \quad 0.3750683707$

H $2.6561527087 \quad-5.3009352107 \quad 0.7645121439$

C $4.3716533358-8.4995957868-0.5636148724$

H $6.1149213339-7.2811129343-0.8560542213$

C $3.0406288733-8.5660029262-0.1254431719$

O $1.1684666536-7.38605950720 .8225833656$

H $4.8417511255-9.4026695319-0.9439729383$

C $2.3106203795-9.8168853132 \quad-0.223563559$

H $0.8091515632-8.30390840350 .7149334163$

H $2.8374634829-10.6563227791-0.6934199608$

N $1.0987286026-9.9242205843 \quad 0.1907381156$

C $0.4065651011-11.14357981730 .0858693186$

C $1.049463615-12.3856654493 \quad 0.215894204$

H $2.109417952-12.40431599750 .4370354568$

C $0.3464686028-13.57393090190 .1070157209$

$\begin{array}{lllll}\text { O } & 0.8874687483 & -14.8084676829 & 0.2195067961\end{array}$

C $2.281669763-14.8981276168 \quad 0.4399249436$

H $2.5687572065-14.4298704541 \quad 1.3887036998$

H $2.8465641913-14.4357623132-0.3783229121$

H $2.5122107649-15.96187860540 .4806914007$

H $15.35778221215 .0330712065-0.497390987$

Page: S91 


\section{References}

(1) Gallant, A. J.; K-H Hui, J.; Zahariev, F. E.; Wang, Y. A.; MacLachlan, M. J. Synthesis, Structure, and Computational Studies of Soluble Conjugated Multidentate Macrocycles. J. Org. Chem. 2005, 70, 7936-7946.

(2) Chaudhry, M. T.; Soto, M. A.; Lelj, F.; MacLachlan, M. J. Diverse Binding of Cationic Guests by Highly Substituted [3+3] Schiff-Base Macrocycles. Org. Chem. Front. 2021, 8, 1437-1446.

(3) Liu, K.; Lalancette, R. A.; Jäkle, F. B-N Lewis Pair Functionalization of Anthracene: Structural Dynamics, Optoelectronic Properties, and $\mathrm{O}_{2}$ Sensitization. J. Am. Chem. Soc. 2017, 139, 1817018173.

(4) Yin, H.; Zhang, B.; Yu, H.; Zhu, L.; Feng, Y.; Zhu, M.; Guo, Q.; Meng, X. Two-Photon Fluorescent Probes for Biological Mg2+ Detection Based on 7-Substituted Coumarin. J. Org. Chem. 2015, 80, 4306-4312.

(5) Bruker. APEX3 and SAINT V. 8.38A. Bruker AXS Inc.: Madison, Wisconsin, USA. 2012.

(6) Sheldrick, G. M. SHELXT - Integrated Space-Group and Crystal-Structure Determination. Acta Crystallogr., Sect. A: Found. Crystallogr. 2015, 71, 3-8.

(7) Sheldrick, G. M. Crystal Structure Refinement with SHELXL. Acta Crystallogr., Sect. C: Cryst. Struct. Commun. 2015, 71, 3-8.

(8) Puschmann, H. OLEX2: A Complete Structure Solution, Refinement and Analysis Program. J. Appl. Crystallogr. 2009, 42, 330-341.

(9) Palmer, D. C. CrystalMaker. CrystalMaker Software Ltd: Begbroke, Oxfordshire, England 2014.

(10) Frisch, M. J.; Trucks, G. W.; Schlegel, H. B.; Scuseria, G. E.; Robb, M. A.; Cheeseman, J. R.; Scalmani, G.; Barone, V.; Petersson, G. A.; Nakatsuji, H.; Li, X.; Caricato, M.; Marenich, A. V.; Bloino, J.; Janesko, B. G.; Gomperts, R.; Mennucci, B.; Hratchian, H. P.; Ortiz, J. V.; Izmaylov, A. F.; Sonnenberg, J. L.; Williams-Young, D.; Ding, F.; Lipparini, F.; Egidi, F.; Goings, J.; Peng, B.; Petrone, A.; Henderson, T.; Ranasinghe, D.; Zakrzewski, V. G.; Gao, J.; Rega, N.; Zheng, G.; Liang, W.; Hada, M.; Ehara, M.; Toyota, K.; Fukuda, R.; Hasegawa, J.; Ishida, M.; Nakajima, T.; Honda, Y.; Kitao, O.; Nakai, H.; Vreven, T.; Throssell, K.; Montgomery Jr., J. A.; Peralta, J. E.; Ogliaro, F.; Bearpark, M. J.; Heyd, J. J.; Brothers, E. N.; Kudin, K. N.; Staroverov, V. N.; Keith, T. A.; Kobayashi, R.; Normand, J.; Raghavachari, K.; Rendell, A. P.; Burant, J. C.; Iyengar, S. S.; J. Tomasi, M. C.; Millam, J. M.; Klene, M.; Adamo, C.; Cammi, R.; Ochterski, J. W.; Martin, R. L.; Morokuma, K.; Farkas, O.; Foresman, J. B.; Fox, D. J. Gaussian 16. Gaussian, Inc.: Wallingford CT 2016.

(11) Chai, J.-D.; Head-Gordon, M. Long-Range Corrected Hybrid Density Functionals with Damped AtomAtom Dispersion Corrections. Phys. Chem. Chem. Phys. 2008, 10, 6615-6620.

(12) Zhao, Y.; Truhlar, D. G. The M06 Suite of Density Functionals for Main Group Thermochemistry, Thermochemical Kinetics, Noncovalent Interactions, Excited States, and Transition Elements: Two New Functionals and Systematic Testing of Four M06-Class Functionals and 12 Other Function. Theor. Chem. Acc. 2008, 120, 215-241.

(13) Francl, M. M.; Pietro, W. J.; Hehre, W. J.; Binkley, J. S.; DeFrees, D. J.; Pople, J. A.; Gordon, M. S. Self-Consistent Molecular Orbital Methods. 2 3. A Polarization-Type Basis Set for 2nd-Row Elements. J. Chem. Phys. 1982, 77, 3654-3655.

(14) Dunning, T. H. Gaussian Basis Sets for Use in Correlated Molecular Calculations. I. The Atoms Boron through Neon and Hydrogen. J. Chem. Phys. 1989, 90, 1007-1023.

(15) Scalmani, G.; Frisch, M. J. Continuous Surface Charge Polarizable Continuum Models of Solvation. I. General Formalism. J. Chem. Phys. 2010, 132, 114110. 